Portland State University

PDXScholar

Fall 12-9-2015

\title{
Exploring Relationships Between Entrepreneurship Education and Students' Entrepreneurial Intentions: A Mixed Method Study of Entrepreneurial Pedagogies at Chilean Universities
}

Paulina Andrea Gutierrez Zepeda

Portland State University

Follow this and additional works at: https://pdxscholar.library.pdx.edu/open_access_etds

Part of the Business Commons, and the Curriculum and Instruction Commons Let us know how access to this document benefits you.

\section{Recommended Citation}

Gutierrez Zepeda, Paulina Andrea, "Exploring Relationships Between Entrepreneurship Education and Students' Entrepreneurial Intentions: A Mixed Method Study of Entrepreneurial Pedagogies at Chilean Universities" (2015). Dissertations and Theses. Paper 2633.

https://doi.org/10.15760/etd.2629

This Dissertation is brought to you for free and open access. It has been accepted for inclusion in Dissertations and Theses by an authorized administrator of PDXScholar. Please contact us if we can make this document more accessible: pdxscholar@pdx.edu. 
Exploring Relationships Between Entrepreneurship Education and Students' Entrepreneurial Intentions: A Mixed Method Study of Entrepreneurial Pedagogies at Chilean Universities

by

Paulina Andrea Gutiérrez Zepeda

A dissertation submitted in partial fulfillment of the requirements for the degree of

Doctor of Education

in

Educational Leadership: Curriculum and Instruction

Dissertation Committee:

Dannelle D. Stevens, Chair

Andrew Job

Candyce Reynolds

Ellen West

Portland State University

2015 
(C) 2015 Paulina Andrea Gutiérrez Zepeda 


\begin{abstract}
Entrepreneurs play a major role in the 21 st century economy, especially in developing countries such as Chile. Entrepreneurial individuals generate innovative ideas, create jobs, and push older businesses to improve competitiveness. To encourage entrepreneurial skills and mindset among the next generation of students, different public and private initiatives have started to include entrepreneurship education (EE) in all levels of education, especially in higher education.
\end{abstract}

Nowadays, EE is not only about business creation, it is about educating individuals to be capable of creating opportunities using entrepreneurial skills to deal with complex and uncertain environments. Yet, while much is known about how entrepreneurs not only create social, environmental, and economic value, the entrepreneurial process is still not understood well enough. This lack of understanding limits our ability to teach entrepreneurship.

The purpose of this mixed methods study was twofold: (1) to explore relationships between faculty teaching perspectives, the experience of the faculty and student entrepreneurial intentions in required entrepreneurship courses at Chilean universities. From this information, I identified those faculty who seem to have differential impact on students entrepreneurial intentions (Phase I: quantitative, secondary data), and (2) to describe and explain how the entrepreneurship faculty define and think about EE and teaching methods (Phase II: qualitative, primary data). 
This study found that the required entrepreneurship courses in a Chilean university had no impact on student entrepreneurial intentions. However, the study also showed that faculty entrepreneurial experience might be a factor that impacts student entrepreneurial intentions. The qualitative part of the study indicated that while faculty hold a perspective in which entrepreneurship is more than simply business creation and are already using some "learning through" entrepreneurship pedagogical elements, but are still primarily basing classes on "learning for" entrepreneurship strategies such as business plan development. 


\section{Dedication}

I would like to dedicate this work to my mother, Winy Zepeda, who always has shown me the right way and she has given me her unconditional support in important moments of my life. She has been a constant source of inspiration and improvement to me. I will always be thankful to her for her unconditional love and because she always has been fully present when I have needed her.

Quiero dedicar este trabajo a mi madre Winy Zepeda, quien siempre me ha mostrado el camino y me ha entregado su apoyo incondicional en momentos importantes de mi vida. Ella ha sido una fuente de inspiración y superación permanente. Le estaré agradecida de su amor incondicional y el estar siempre presente cuando la he necesitado. 


\section{Acknowledgments}

Earning my Ed.D. has definitely been a learning journey. Completing this stage of my life, I would like to thank my family which has always supported me and believed in me, especially on those days where homesickness and tiredness seemed to be an obstacle to reaching this goal. Thank you for your continuing support and sending good thoughts from my dear Coquimbo, Chile. Thanks to Winy, Ricardo, Julian and Niky.

I would also like to thank my dear professor and Chair Dr. Dannelle D. Stevens, who has been a very supportive advisor and good mentor. Thanks for all of her help during this process and also for her unconditional support, comments and suggestions for improvement. Also, thanks for teaching me to find the passion in what I do and what I write and why. Thanks for showing me the right way of writing and being a guide for me in many ways. Her help has been a great gift in my life during this journey. I would also like to thank my dissertation committee: Dr. Andy Job, Dr. Candyce Reynolds, and Dr. Ellen West for all their support, time, and helpful feedback.

I also thank my girlfriends who have accompanied me in this process from the day I started this trip and arrived in my beautiful Portland. They were courageous women and faithful companions all these years, handing giving me all their love and help in different ways. Thanks to Janet, Carito R, Irene, Dani, Lucy, Caro F., Karol, Carmen, and Tatiana for always being present and available. Thanks also to Daveena for her professional support and for helping me improve my English writing. I will be forever grateful for her commitment toward my development as a student and researcher. Also I want to mention especially my dear friends Ramon, Cristian, Rodrigo Sfeir and especially 
Rodrigo Rojas for their love and understanding in key moments, especially during this last period of time.

Last, but not least, I want to thank the faculty participants in this study. I am honored to have worked with them to have learned from their open and honest sharing of experiences. I am excited and inspired to continue researching in this area. Finally, I would like to acknowledge to The Commission Fulbright-Chile Scholarship for covering my tuition while pursuing my doctorate studies. 
Table of Contents

Page

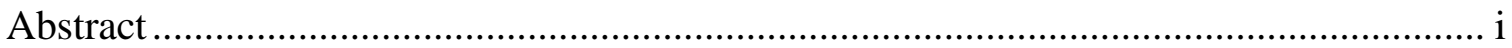

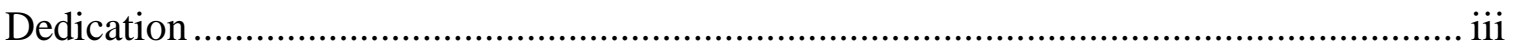

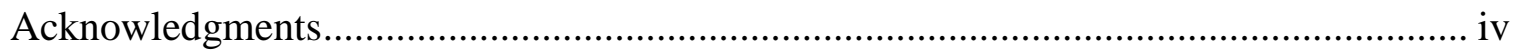

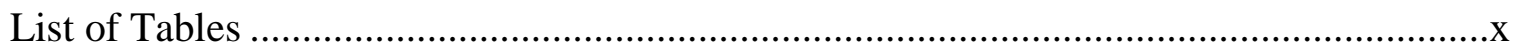

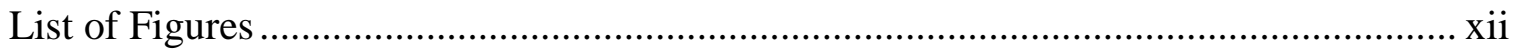

\section{Chapter 1}

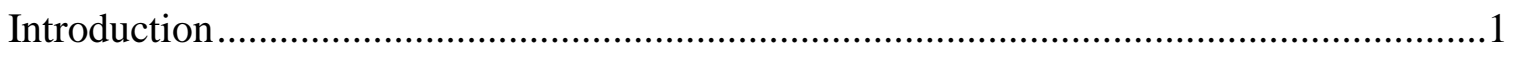

Purpose of the Study and Research Questions....................................................

Entrepreneurship as an Academic Field ......................................................4

EE

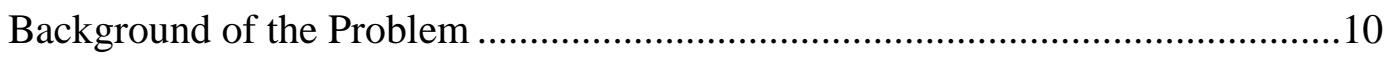

Global Need for EE: Societal Benefits ...............................................10

EE: From Global to Local Chilean Context...........................................12

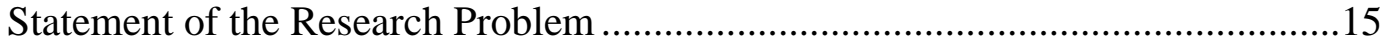

Significance of the Research Problem for Chile ...............................................19

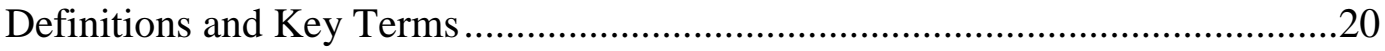

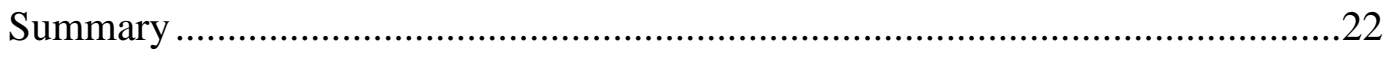

\section{Chapter 2}

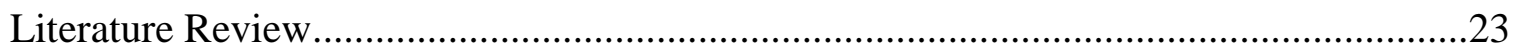

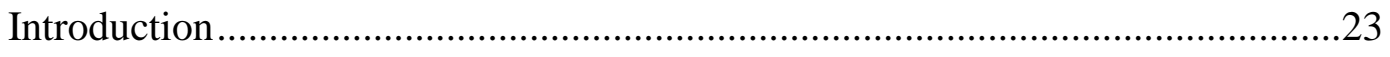

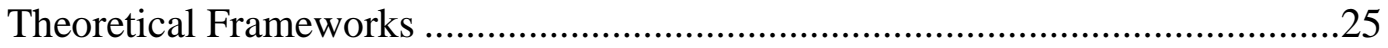

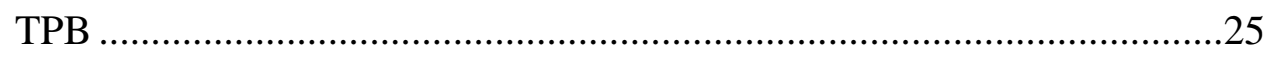

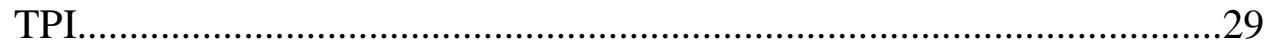

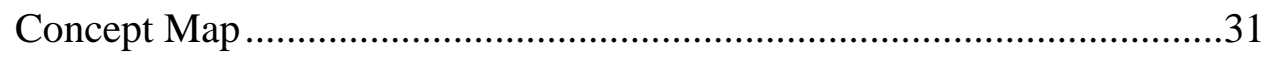


Literature Review in Entrepreneurship in Higher Education ............................32

Schools of Thought in Entrepreneurship Research..........................................35

Traditional Theories in Entrepreneurship Research ..........................................35

Emerging Theories in Entrepreneurship Research ..........................................37

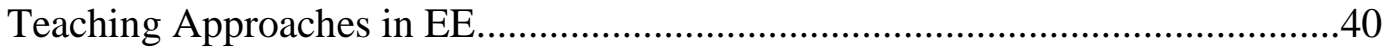

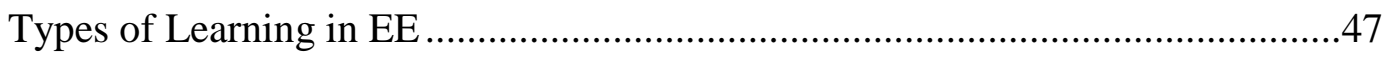

Learning about entrepreneurship ...................................................50

Learning for entrepreneurship......................................................52

Learning through/in entrepreneurship ..............................................53

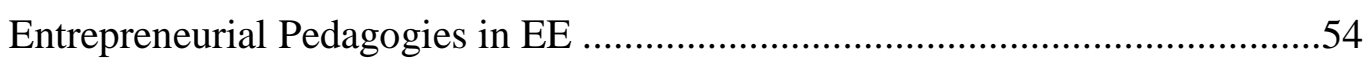

Traditional/Passive Pedagogies in Entrepreneurship...............................57

Innovative/Active Pedagogies in Entrepreneurship..............................59

Review of Methodological Literature in EE ..................................................62

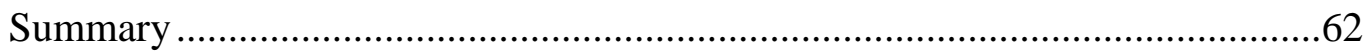

\section{Chapter 3}

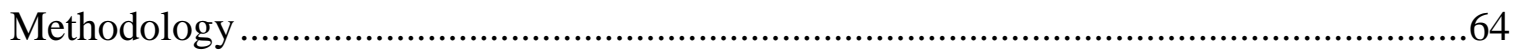

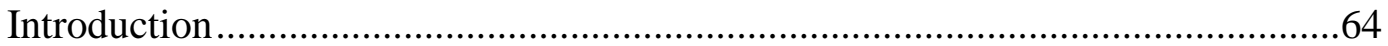

Purpose of the Study and Research Questions...............................................64

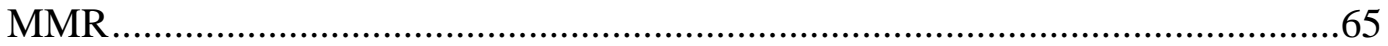

Explanatory Sequential MMR Design ...............................................67

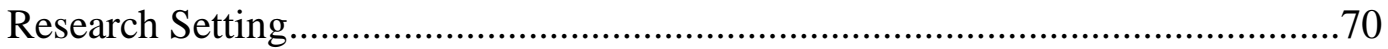

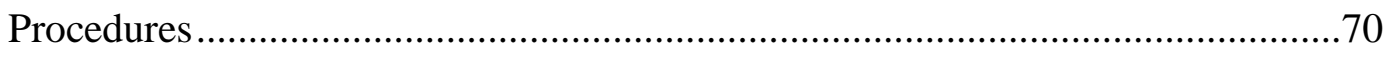

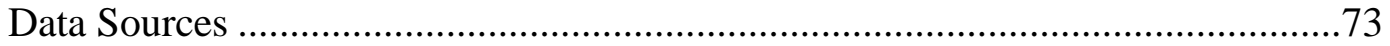

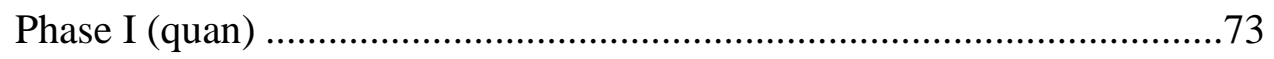

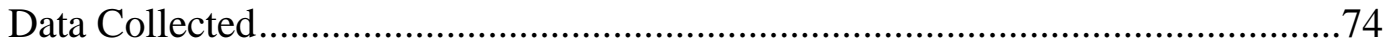

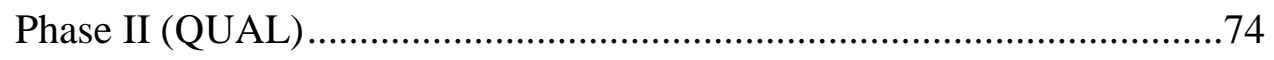

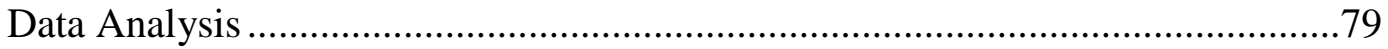

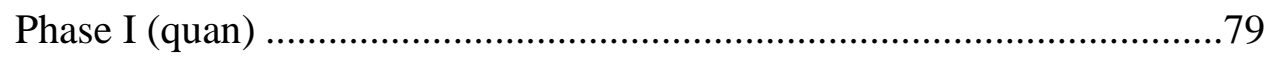




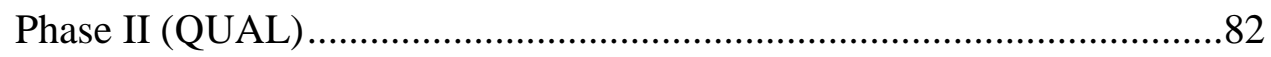

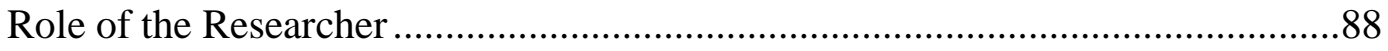

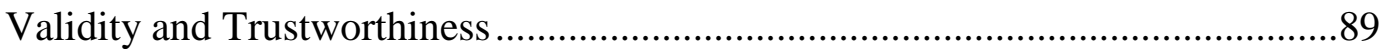

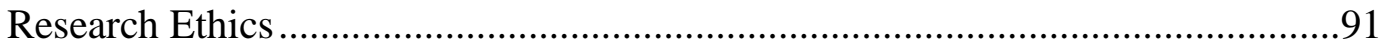

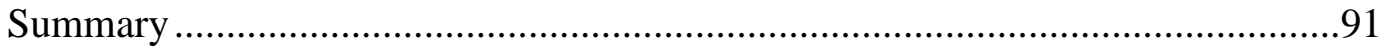

\section{Chapter 4}

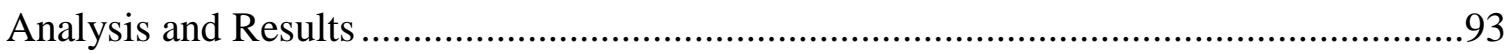

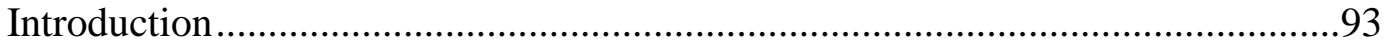

Purpose of the Study and Research Questions........................................................94

Analysis of Data Phase I: Quantitative Phase (quan) ………………....................95

Student Entrepreneurial Intentions ……………………...........................95

Faculty's Entrepreneurial Experience ………………………………......102

Differences Between Means on the Student Entrepreneurial

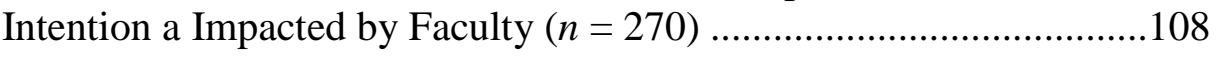

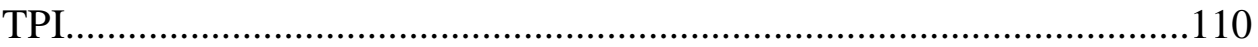

Summary of the Primary Results in Phase I (quan).................................117

Analysis of Data Phase II: Qualitative Phase (QUAL) ........................................121

Overview Participants Interviewed.........................................................121

Thematic Network Analysis ...................................................................122

Analysis of the Pedagogies .....................................................................133

Analysis of Syllabi as Artifacts...........................................................140

Summary of the Primary Findings in Phase II (QUAL .............................143

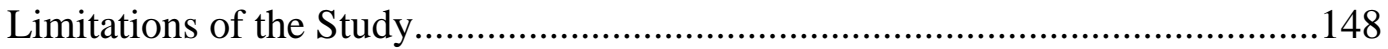

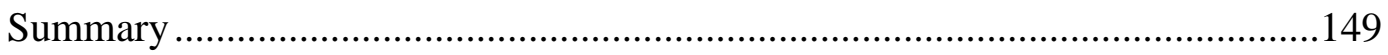

\section{Chapter 5}

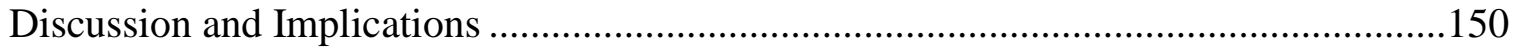

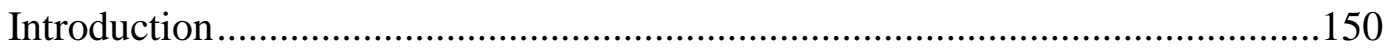


Purpose of the Study and Research Questions..................................................150

Discussion of Results by Research Question....................................................152

Research Question 1 .......................................................................152

Research Question 2............................................161

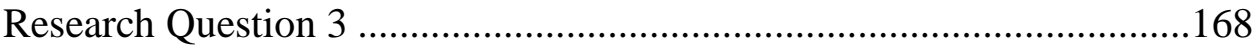

Research Question 4............................................. 174

Research Question 5 ...................................................................178

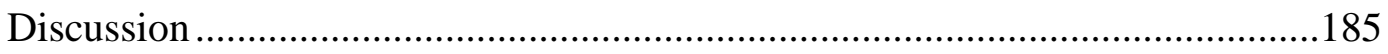

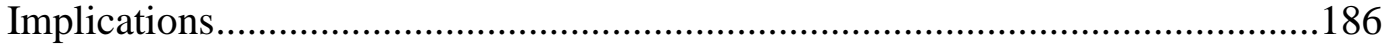

Recommendations for Future Research ............................................................191

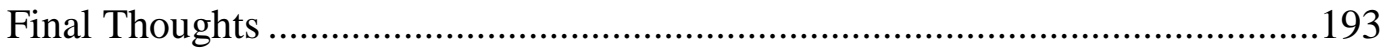

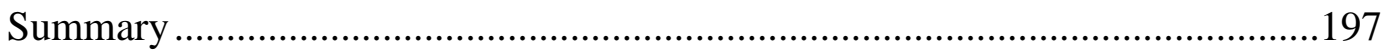

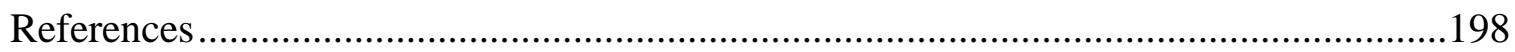

Appendices

A Summary of Five Perspectives on Good Teaching ...........................................212

B Survey Students (English) ..............................................................................214

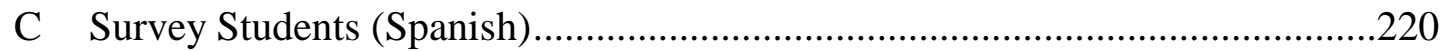

D Survey Faculty (English) ..............................................................................226

E Survey Faculty (Spanish) .............................................................................234

F Interview Guide Faculty (English) ...............................................................243

G Interview Guide Faculty (Spanish) .............................................................24 
List of Tables

Table

Page

1 Teaching Models for Entrepreneurship in Higher Education...........................42

2 Entrepreneurship Teaching Approaches.....................................................45

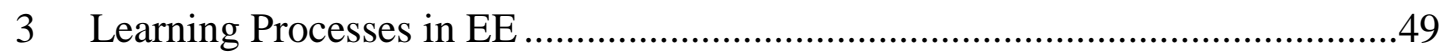

4 Procedures in Explanatory Sequential MMR (quan $\rightarrow$ QUAL) ..........................71

5 Interview Protocol Entrepreneurship Faculty ...............................................76

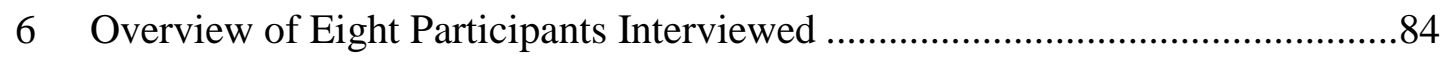

7 Dependent $t$ test Student Entrepreneurial Intention.........................................96

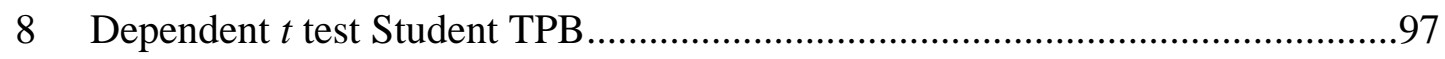

9 Dependent $t$ test Student Entrepreneurial Intention Subsample ........................99

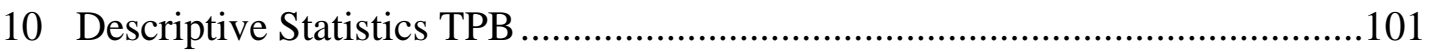

11 Descriptive Statistics Entrepreneurial Experience ......................................102

12 Crosstabulation Entrepreneurial Experience and Faculty's Gender..................103

13 Paired Sample Student Entrepreneurial Intention/Faculty Experience .............105

14 Paired Sample Student Entrepreneurial Intention/Current Faculty

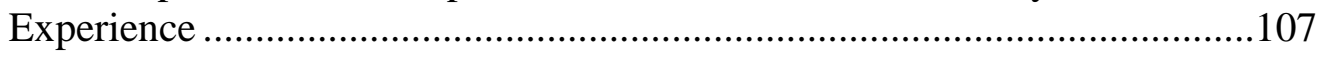

15 Paired Sample Student Entrepreneurial Intention by Faculty .........................109

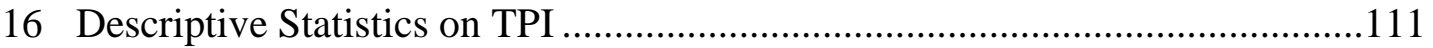

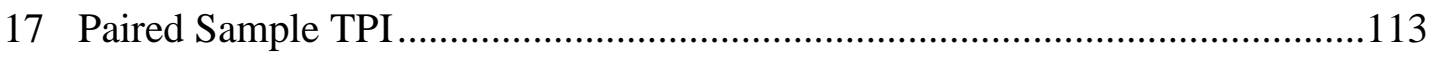

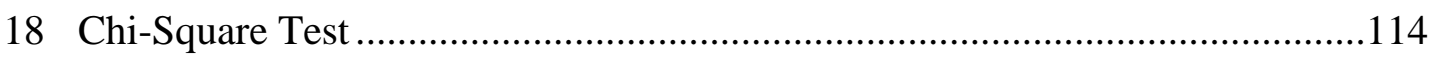

19 ANOVA test TPI and Entrepreneurial Intentions .....................................115

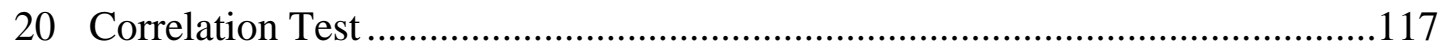

21 Summary of Impact Pre and Posttest Entrepreneurial Intention .....................118

22 Summary of Impact Entrepreneurial Intention by Faculty Experience .............119

23 Overview of Interviewed Participants ......................................................122

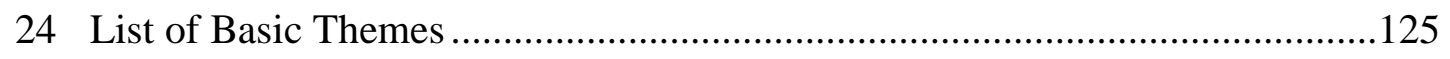

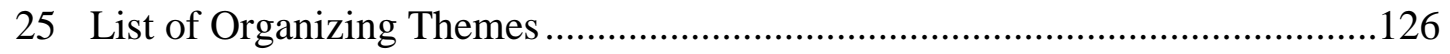

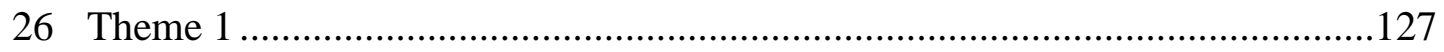

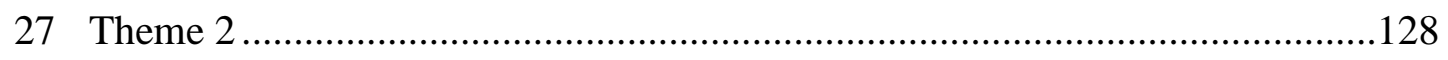




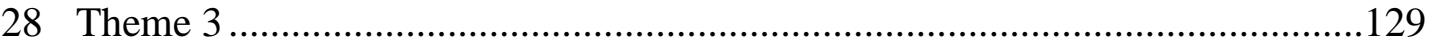

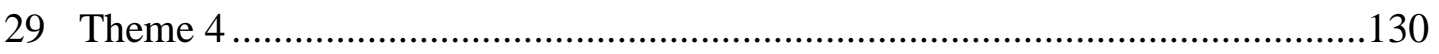

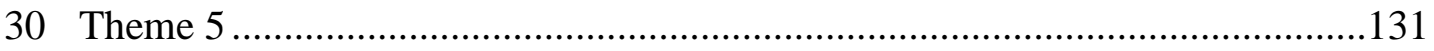

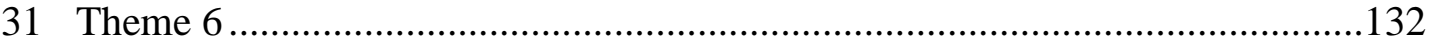

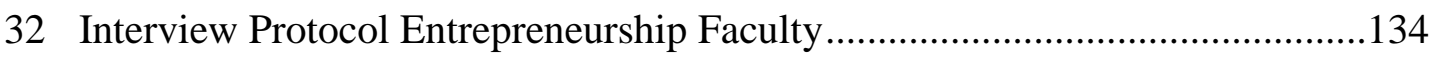

33 Traditional or Passive Pedagogies ........................................................... 135

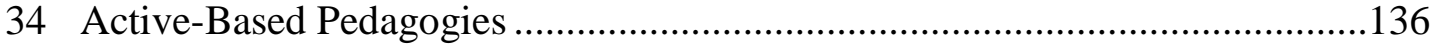

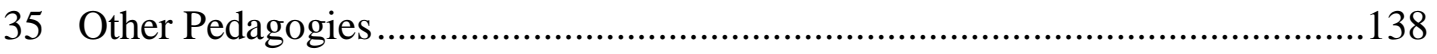

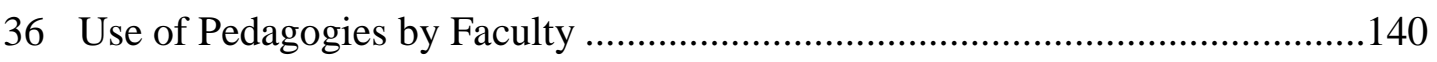

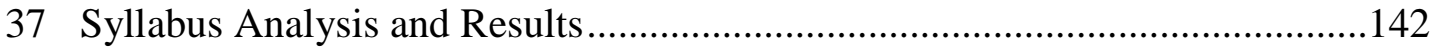

38 Impact of a Required Entrepreneurship Course ........................................153

39 Impact of Entrepreneurial Intention and Faculty Entrepreneurial Experience..157

40 Impact of Entrepreneurial Attitude and Faculty Entrepreneurial Experience ...158

41 Quantitative and Qualitative Data by Faculty Interviewed ............................180 
Figure

List of Figures

1 The ТРВ

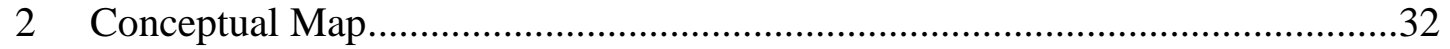

3 Traditional Versus Innovative Pedagogies in EE .........................................56

4 Explanatory Sequential Design in MMR (quan $\rightarrow$ QUAL) ...............................68

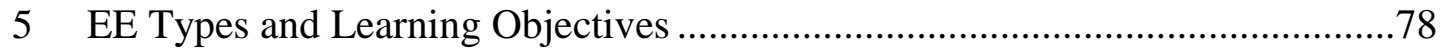

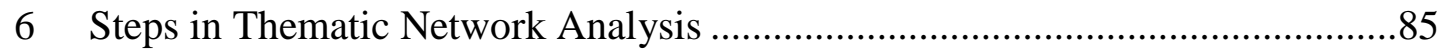

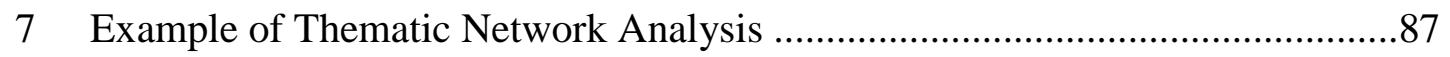

8 Photos of the Manual Process of Coding (Recurrent Issues) ...........................123

9 Photos of the Manual Process of Coding (Basic Themes) ...............................124

10 Relationship Between Types of Pedagogies Used by Faculty .........................139

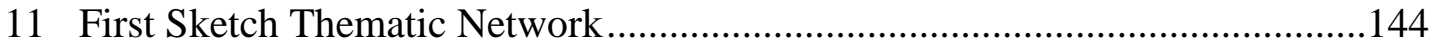

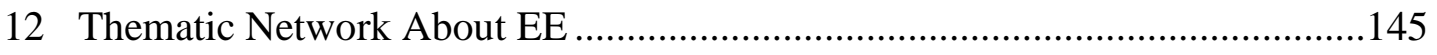

13 Thematic Network About Entrepreneurship Teaching.................................146

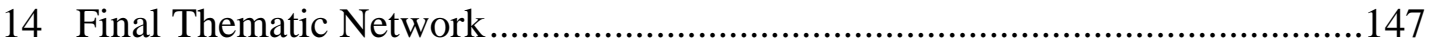

15 Graphic Representation of the Teaching Profile by Faculty ...........................159

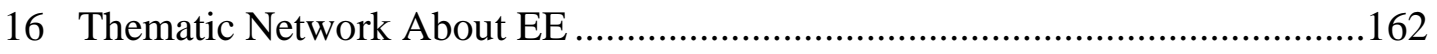

17 Thematic Network About Entrepreneurship Teaching...................................168

18 Approaches of Teaching Entrepreneurship ................................................172

19 Classification of Types of Pedagogies used by faculty ..................................175

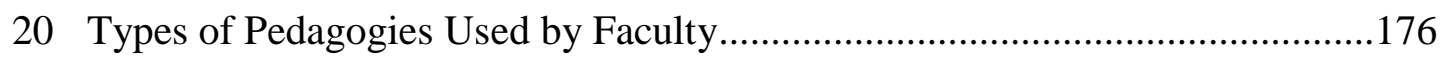

21 Theory-Practice Matrix in Teaching Entrepreneurship .................................181 


\section{CHAPTER 1}

\section{INTRODUCTION}

The dynamic marketplace in our global society requires that college students become entrepreneurial individuals capable not only discovering opportunities that other overlooked and finding a job, but being able to create one. Yet, the field of entrepreneurship education (EE) has sometimes raised the question: are entrepreneurial skills a genetic gift or are they the result of a specific educational process? If entrepreneurship is considered a teachable subject, what are the best practices to deliver and foster entrepreneurial skills in education settings?

In Chile, EE is a relatively new phenomenon in Chile, entrepreneurship education programs (EEP) and courses started mainly in the 2000s and they vary widely in terms of short terms objectives, target audience, format and pedagogical approaches (mineduc.cl). The trend toward offering EE among universities and business schools has risen over the last decade. In fact, this tendency to offer entrepreneurship classes among private and public universities is growing rapidly and it is going beyond business schools curricula

(mineduc.cl). Currently, among the 59 private and public Chilean universities, more than $60 \%$ of business schools or departments, already include, or are evaluating whether to include EE as part of their programs (Sistema de Investigación Educación Superior Chile, 2015). Offering new entrepreneurship programs or redesigning current business curricula toward entrepreneurship have been attractive opportunities for universities, especially as a result of public policy and incentives. For instance, the most prestigious Chilean universities (University Adolfo Ibáñez, Universidad of Chile, and Catholic University 
already include or are evaluating whether to include EE as part of their programs (Mejoramiento de la Calidad de Educacion Superior, 2015).

Through this research study, I explored relationships between some educational variables in EE such as faculty's perspectives of teaching based on the teaching perspective inventory (TPI) and the pedagogical methods used in entrepreneurship classroom and how those pedagogies might affect students' entrepreneurial intentions in universities in Chile. The results of this study might contribute to a better understanding of $\mathrm{EE}$ as a teaching and learning process in Chile. And it will help entrepreneurship educators develop and implement the best pedagogies to foster students' entrepreneurial learning as well as to achieve the specific outcomes that universities and educators pursue in their programs.

This research study is structured in five chapters. Chapter 1 describes the research problem, which involves how to teach entrepreneurship in higher education institutions most effectively and discusses EE as an academic field. Chapter 2 discusses the literature review on EE in higher education that supports the problem of research. Next, chapter 3 explained the methodology that I used in this research; articulating the research questions with the problem in practice. I also discuss the selection of mixed methods research (MMR) approach as the best option to address the research questions. Specifically, this study use an explanatory sequential research design (quan $\rightarrow$ QUAL), that considers the quantitative data, Phase I, as the preliminary input for collecting and interpreting the qualitative data in forms of interview in Phase II. Chapter 4 presents the results of the two chronological Phases I and II in this research study and chapter 5 provides a discussion of 
findings organized by research questions. Finally, I provided implications and offer directions for further research.

In chapter I, I describes the background of the topic of EE, how entrepreneurs are educated, and how academic programs in entrepreneurship can influence entrepreneurial behaviors and skills. Then, I move on to stating the purpose and rationale for this study, explaining the significance of this problem. Finally, I provide definitions of key terms and a brief summary of chapter 1 .

\section{Purpose of the Study and Research Questions}

The purpose of this study was twofold: (a) to explore relationships between faculty teaching perspectives and the experience of the faculty and student entrepreneurial intentions in required entrepreneurship courses at Chilean universities. From this information, I identified those faculty who seem to have increased impact on students' entrepreneurial intentions (Phase I: quantitative, secondary data), and (b) to describe and explain how entrepreneurship faculty define and think about EE and teaching methods (Phase II: qualitative, primary data).

The research questions (RQ) for this study were:

RQ1: How do the perspectives (beliefs) about teaching as measured by the TPI and the entrepreneurial experience by faculty in entrepreneurship courses relate to the entrepreneurial intentions level of students in their classes? (quan)

RQ2. How do identified entrepreneurship faculty describe EE? (QUAL)

RQ3. How do identified entrepreneurship faculty describe the relationship between entrepreneurship teaching and entrepreneurial learning? (QUAL) 
RQ4. How do identified entrepreneurship faculty describe and explain the selection and the use of pedagogical methods? (QUAL)

RQ5. In what ways do faculty understandings of entrepreneurship teaching and pedagogies (QUAL) help to explain the relationship between faculty perspectives about teaching, the pedagogies they use, and student entrepreneurial intention (quan)?

In this study, the entrepreneurial intention is a psychological construct measured at the individual level that demonstrates the intentional process to start a business or to become a more entrepreneurial individual (Azjen, 1991; Krueger, Reilly, \& Carsrud, 2000; Mueller, 2011; Von Graevenitz, Harhoff, \& Weber, 2010). This research study is pertinent to the Chilean context because EE has experienced a remarkable expansion in all level of education over the last 10 years (OECD, 2008; Volkmann, Wilson, Marlotti, Rabuzzi, Vyakarnam \& Sepulveda, 2009; Global Entrepreneurship Monitor [GEM], 2011). Indeed, the rise of EEP in universities in Chile has been fueled by government incentives to higher education institutions and an unprecedented student demand for an education that provides skills needed to succeed in an increasingly divergent business environment (Lepeley \& Albornoz, 2011).

\section{Entrepreneurship as an Academic Field}

Entrepreneurship plays a role in fostering innovations that lead to increase productivity (Kuratko, 2005) and it is strongly associated with economic growth of local economies (GEM, 2008; 2011). Entrepreneurship as an academic field has a vital role in guiding learners to become more entrepreneurial mindset meaning to develop entrepreneurial skills currently very valued in any society. Entrepreneurial individuals are 
better prepared to deal with entrepreneurial activities in uncertain and complex environments (Neck \& Greene, 2011). In the past, the question of whether entrepreneurship can be taught at all was the primary teaching dilemma in EE. Nowadays, however, the emphasis is on how entrepreneurship can best be taught in higher education institutions (Fayolle, 2013). Ultimately, the teaching focus is moving toward to a learning focus. Instead of wondering how entrepreneurship should be taught, researchers need to ask how should entrepreneurship be learned? (Neck, Greene, \& Brush, 2014).

The distinctive domain of entrepreneurship scholarship consists of the study of opportunities for value creation (Venkatamaran, 1997). The critical cultural roles of entrepreneurship include advocating for sustainable growth, creating economic activity, and promoting community involvement (O'Connor, 2012). Several researchers agree that entrepreneurship and entrepreneurs not only create social, environmental, and economic value inside organizations but that it also helps individuals to identify, create, and capture the right opportunities outside organizations in an increasingly complex and globalized world (Arthur, Hisrich, \& Cabrera, 2012; Cope, 2005; Griffiths, Kickul, Bacq, \& Terjesen, 2012; Kirby, 2004; Mars \& Rios-Aguilar, 2010; Neck \& Greene, 2011; Vesper \& Gartner, 1997).

In the context of this research study, entrepreneurship as a field of research is defined as the process that involves "the discovery, the evaluation and exploitation of opportunities" (Shane \& Venkatamaran, 2000, p. 218). The original French term "entreprendere" accurately reflects what entrepreneurship is about. For instance, Chia (1996) explains this word etymologically, by dividing it into two terms: (1) entre: 
meaning "to enter or to penetrate in between" and (2) prendere/prehendere: meaning "to grasp or seize hold of' (p. 413). This concept aligns with some researchers who identify entrepreneurs as innovative people who undertake to make things happen (Baumol, 2012). Thus, EE is not an exact science, it can be seen as a skill set that can be learned through a dynamic mix process of process and action that refers to the development and enacting of opportunities (Sarasvathy, 2008a).

A more elaborated definition, by Neck and Greene (2011), Read and Sarasvathy (2005) and Cope (2005), suggested that EE is an inter-related learning process that implies identifying (creating or discovering), evaluating and acting on opportunities in uncertain environments. Nowadays, EE is not only about business creation, but is a broader subject that has been implemented beyond the business schools in universities. EE does not necessarily mean that everyone has to start a business, but individuals should be capable of creating or discovering opportunities using entrepreneurial skills. Given that $\mathrm{EE}$ is a hot topic on the American and European political agendas, national projects are booming worldwide and entrepreneurship courses are being developed by universities, particularly business and engineering schools, as well as other educational institutions such as secondary and primary schools. (Byrne, Fayolle, \& Toutain, 2014; Fayolle, 2013) According to the literature, some of the purposes of entrepreneurship as an academic field are: to facilitate the creation of new businesses through innovation and creativity (Kirby, 2004; Neck \& Greene, 2011; Rae, 2005); to help nascent entrepreneurs (students) developing entrepreneurial skills, attitudes, and behaviors (Fayolle, 2013); and to educate and train potential entrepreneurs through new way of thinking (Savarsthy, 
2008b). Therefore, EE is not only a pedagogical issue but an ontological one related to the aspects of how to define entrepreneurship and how to approach the process of value creation and opportunity identification (Brush et al., 2003; Mäkimurto-Koivumaa \& Puhakka, 2013).

\section{EE}

It is worth noting that entrepreneurship does not necessarily imply the creation of new business organizations. Entrepreneurship can take place in existing companies and restructure diverse types of organizations such as private businesses, public or non-profit organizations (Fayolle \& Linan, 2013). Entrepreneurship is about entrepreneurial individuals interacting with their environment, thus creating, discovering, evaluating and exploiting opportunities in the marketplace (Heinonen \& Poikkijoki, 2006). Therefore, $\mathrm{EE}$ is about more than creating new small businesses or a career choice for selfemployment. For individuals, EE is an educational process that helps them develop an orientation toward innovation and action because the entrepreneur changes while she/he perceives an opportunity to create new ideas, products or ventures, and new processes in existing organizations (Cope, 2005; Kuratko, 2005).

There is still some conceptual confusion regarding what EE is and what it aims to accomplish. This confusion appears because the process of designing EEP is not explicit and there are some problems in aligning relevant components such as entrepreneurship content, learning outcomes, assessments, and the context in which EEP are delivered (Maritz \& Brown, 2013). The subject of EE is still not well understood and consequently much of the efforts to teach entrepreneurship are limited in terms of efficacy. Conceptual 
and contextual difficulties have contributed to a fragmented field of research (Fayolle, 2013) and to the ongoing debate about the impact of EE (Matlay, 2010). Hence, entrepreneurship educators should raise questions about what they are really doing when they teach and train people in entrepreneurship. Specifically, this study looked how to articulate theoretical foundations and didactical classrooms practices that lead to more research-based practice in EE with the goal of creating greater effectiveness and better students learning.

Recent research in EE relates to the lack of theoretical development and pedagogical methods in the field as key issues that undermine the legitimacy of EE as a research field (Molina-Azorín, López-Gamero, Pereira-Moliner \& Pertusa-Ortega, 2012). Baumol (2010) argued for more experimentation and government support of research on ways to improve the teaching of entrepreneurship because there is little evidence about what works and what does not work in entrepreneurship programs. Moreover, there appears to be a lack of understanding in EE about what new or emergent pedagogical methods can be used to encourage and support entrepreneurship learning and thinking (Fayolle, 2007). This is crucial to this research study, because according to recent research in EE, in order to design and deliver effective entrepreneurship teaching, it is important to understand what components or educational variables of EEP influence the intention to become an entrepreneur as well as to explore the nature of the relationships between those EEP components (Mueller, 2011).

According to Fayolle and Gailly (2008), there is a great disconnect between the field of education and entrepreneurship. There is little agreement about good practices in 
EE, particularly in terms of philosophical and pedagogical levels. Researchers suggest that educators in EE should combine knowledge from education theory and entrepreneurship research and work together to align content and pedagogical methods with specific audiences. The main future research on EE is to develop coherent teaching models that provide effective measure of the instruction delivered by educators in terms of achieving entrepreneurship outcomes (Kantis, 2008).

When it comes to the topic of EE, one of the first controversial issues was the discussion about whether entrepreneurs are born or made. Today, there is common agreement among scholars that entrepreneurship can be taught (Neck \& Greene, 2011; Rae, 2005). However, recent scholars in EE argue that in order to develop and improve effectiveness in entrepreneurship programs and courses, educators and professionals in EE should move beyond the myth that entrepreneurs are born not made, which still persist to some extent (Kuratko, 2005; Sarasvathy, 2008a, 2008b).

Proponents of EE maintain that, in spite of focusing only on the personal characteristics of the entrepreneur, entrepreneurship educators should emphasize how entrepreneurship can best be taught rather than whether entrepreneurship can be taught. In order to do that, educators in entrepreneurship should incorporate more theoretical knowledge from entrepreneurship research into teaching (Winkel, 2013). Specifically, we need to understand the correspondence between educational variables or components of EEP such as perspectives of teaching, pedagogies and learning outcomes to find whether those components have an impact on the participant's intention to become an 
entrepreneur (Fayolle, 2007; Mueller, 2011). Therefore, as entrepreneurship educators we need to understand what we teach in EE, how we teach it, and for what purposes.

\section{Background of the Problem}

EE is a field of study that has evolved dramatically over the last three decades (Katz, 2003, 2008; Mars \& Rios-Aguilar, 2010; Sarasvathy \& Venkataraman, 2011). Not only has entrepreneurship grown in legitimacy as an academic and research field (Fayolle, 2007), it has also gained worldwide recognition as an important activity for a country's competitiveness and economic growth (Makimurto-Koivumaa \& Puhakka, 2013; Neck \&

Greene, 2011). At its core, EE supports the discovery or creation of new market opportunities for the development of entrepreneurial skills, behaviors, attitudes (Gibb, 1993) and thinking (Krueger, 2007) in young people whatever their career choice might be in their future plans.

Despite the fact that there is a common understanding that EE has to deal with complexity and uncertainty (Neck \& Greene, 2011) and have a positive impact on participant's entrepreneurial intentions to become an entrepreneur (Mueller, 2011); still there is a growing need for entrepreneurship educators knowing the best and most effective pedagogical methods to fostering entrepreneurial thinking and skills in university students (Fayolle, 2013; Matlay, 2006; Winkel, 2013).

\section{Global Need for EE: Societal Benefits}

Educating people in entrepreneurship is important because it serves to train and motivate potential entrepreneurs to address organizational and social problems through idea generation and innovation (World Bank, 2013). Governments also have persisted in 
encouraging the population to become entrepreneurial individuals because it is seems that new businesses create more jobs and plays a role in boosting the competitiveness of local economies (Reynolds, 2007). Ultimately, entrepreneurship has become a significant source of economic and social mobility that has been spreading as it is implemented worldwide (Katz, 2003; Kirby, 2004; Mwasalwiba, 2010).

The importance of EE also was stressed in the Global Education Initiative Report of the World Economic Forum (Volkmann, Wilson, Marlotti, Rabuzzi, Vyakarnam \& Sepulveda, 2009):

... while education is one of the most important foundations for economic development, entrepreneurship is a major driver of innovation and economic growth. Entrepreneurship education plays an essential role in shaping attitudes, skills and culture-from the primary level up .... we believe entrepreneurial skills, attitudes and behaviors can be learned, and that exposure to entrepreneurship education throughout an individual's lifelong learning path, starting from youth and continuing through adulthood into higher education-as well as reaching out to those economically or socially excluded-is imperative. (pp. 7-8)

This is clear evidence that EE has been identified as the core of the Global Education Initiative supportive not only by World Economic Forum but also by many governments worldwide. Indeed, EE is able to foster entrepreneurial skills and mindsets that are similar to the survival skills that young students and new professionals need to learn for the 21st century (Zhao, 2012).

The Organization for Economic Co-operation and Development (OECD) has recognized that $\mathrm{EE}$ "is concerned with the inculcation of a range of skills and attributes, including the ability to think creatively, to work in teams, to manage risk and handle uncertainty" (OECD, 2009, p. 5). EE as a teaching field can help educators provide a mix of experiential learning, skill building, and most importantly, attitude shifts that support 
students' entrepreneurial behavior (OECD, 2008, 2009). Moreover, emergent entrepreneurship theories among scholars suggest that entrepreneurial skills, attitudes, and behaviors definitely can be taught (Sarasvathy, 2008b). However, more discussion is needed regarding how these qualities can best be taught. More research is required on the development of appropriate educational methods of teaching and learning in EE because researchers on entrepreneurship do not yet know well what works in teaching entrepreneurship (Baumol, 2012; Fayolle, 2013; McMullan \& Long, 1987; Plaschka \& Welsch, 1990).

\section{EE: From Global to the Local Chilean Context}

EE has grown and gained recognition as an emergent field of study in the U.S. and worldwide (Fayolle, 2013). In the American higher education system, it was Joseph Schumpeter in the 1940s who first described entrepreneurship as a process of creative destruction or breaking patterns which implies provoking change through innovation (Schumpeter, 1934). According to the Schumpeterian school of thought in entrepreneurship, the entrepreneur identifies opportunities to create economic value through the process of doing something that is outside of the range of the existing practice (Gibb, 2002). In the U.S., the first entrepreneurship class in business programs was offered in 1947 at Harvard University by Myles Mace (Katz, 2003). Over the years, EE has been acknowledged as a discipline with its own status according to the United States Academy of Management and it has climbed the ranks in the business domain with entrepreneurship journals growing in importance among peer-reviewed management journals (Fayolle, 2007: Katz, 2008). 
Currently, the number of publications on EE has grown 300\% from 2000 to 2010 (Kozlinska, 2011). In 2003, there were only four entrepreneurship journals listed in the Social Science Citation Index (SSCI). Ten years later, there are 10 mainstream journals in EE ranked as the most influent worldwide (Fayolle \& Wright, 2014). Nowadays, in the U.S., EE is an academic and research discipline supported by more than 2000 courses offered at more than 1,600 postsecondary institutions, more than 100 centers of study on entrepreneurship, and more than 40 academic journals (Katz, 2003; 2008; Kuratko, 2005).

Higher education institutions worldwide have become one of the major contributors to fostering entrepreneurial behavior in potential entrepreneurs (Fayolle, 2013; Gibb, 2002). EE in universities can help students develop entrepreneurial skills that contribute to an increase in the number of new businesses in the overall society (Gibb, 2002; Greenberg, McKone-Sweet, \& Wilson, 2011; Hindle, 2007; OECD, 2009). However, current EE research highlights that due to a wide range of types, models, and methods to deliver EE, there is little agreement about some fundamental issues such as how entrepreneurship is defined (Fayolle \& Gailly, 2008), what learning objectives or outcomes are needed, what the most effective teaching methods and pedagogies are, and how impact indicators for assessment are defined (Gibb, 1996; Maritz \& Brown, 2013; Mwasalwiba, 2010; Mueller, 2011; Neck \& Greene, 2011; Rae, 2005).

Despite the fact that American universities have pioneered the inclusion of EE in business programs, Europe and some developing countries in Latin America are not far behind (Alvarez \& Urbano, 2011). The European higher education system has been increasing its interest in developing and implementing an entrepreneurship curriculum 
since the mid-1990s (OECD, 2008). Lately, researchers from countries such as UK, Finland, and Germany have increased the production of research articles on EE, especially about contemporary approaches to EE (Kozlinska, 2011). This supportive stance toward EE has been increasingly embraced by many developing countries (GEM, 2011). Latin America is no exception and countries such as Colombia, Mexico, and Chile have seen entrepreneurship as the key approach to stimulating increased levels of economic activity and competitiveness. Today, Latin American countries are making special efforts to improve competitiveness through innovation and EE (Xavier, Kelley, Kew, Herrington \& Vorderwülbecke, 2013; Klinger \& Schundeln, 2011).

Even though EE is a relatively new phenomenon in Latin America, entrepreneurship programs and courses have been rapidly expanding among universities and business schools, especially in Colombia, Brazil, and Chile. Nowadays, Chile is one of leaders in the Latin American region because it has shown consistent economic growth and low unemployment rates (Xavier, Kelley, Kew, Herrington \& Vorderwülbecke, 2013). In the last Doing Business report (World Bank, 2013), which investigates the regulatory activity and public policies favoring or constraining business, Chile was first in Latin America (classified 37 in the general ranking) while Colombia (45) and Mexico (48) follow.

With these positive economic results, the Chilean government is convinced that innovation and entrepreneurial activities will assist Chile in becoming a pioneer among Latin American countries through its competitiveness. However, there are many questions still unresolved about the effectiveness of EE, the pedagogical methods used by 
educators, or the outcomes of EEP. Little research in Chile has explored EE and how entrepreneurship classes influence entrepreneurial intention (Albornoz, 2012; 2014). To the best of my knowledge, no research in Chile has explored educational variables in EEP. Specifically, there is no previous research in Chile about how different perspectives of teaching and pedagogical methods used by faculty in EE might impact students' entrepreneurial intention to start a business.

Evidence of the need for more research in EE can be found in various special issues of the most important journals in EE which explicitly encourage entrepreneurship researchers to address the interrelationship between EEP and the entrepreneurial intentions of their participants (Fayolle, 2013). In Chile, the evidence for more research is supported by the recent formation of the entrepreneurship educators groups under the umbrella of ASECH (Asociación de Emprendedores de Chile), the Chilean entrepreneurship researchers association created in January 2012, and the increasing public funding to research the impact of EE in Chile (Comisión Nacional de Investigación Científica y Tecnológica, 2014).

\section{Statement of the Research Problem}

Incorporating perspectives on educational theories and pedagogical practices into entrepreneurship research could facilitate fostering entrepreneurial skills in students as well as achieving learning outcomes commonly known in EE (Fayolle, 2013; Hannon, 2006; Pittaway \& Cope, 2007b). One way to frame the lack of understanding and agreement about the best way to teach EE is to understand that methods for teaching entrepreneurship vary extensively and are usually related to assumptions about how EE is 
defined and what students should learn in entrepreneurship courses (Bennett, 2005). Essentially, I am arguing that researchers and educators need a deep understanding of the components of the EEP because those components require an appropriate coherence and alignment.

For instance, different beliefs about education impact teaching practices used in classrooms and diverse types of learning outcomes in EE require different methodological and pedagogical approaches to deliver effective instruction (Hannon, 2006). In sum, then, the review of the literature on EE and my own observations suggest that there is not yet a thorough understanding of how faculty in universities are currently teaching entrepreneurship and whether those methods and practices are effective (Fayolle, 2013).

If entrepreneurship educators are called to incorporate new approaches to teaching entrepreneurship, then we need to explore and understand how and why educators select and use pedagogical methods as well as to test different dimensions of the effectiveness of those pedagogical methods used. For instance, if entrepreneurship educators are to select methods according to what is most effective in order to achieve their stated goals (Ruskovaara \& Pihkala, 2013), then we need to identify the most effective methods to reach those goals and train entrepreneurship faculty.

Recent literature on EE identifies various entrepreneurship outcomes in order to assess effectiveness in entrepreneurship courses. Diverse approaches to measuring EE outcomes have been used in entrepreneurship research. For instance, some researchers look at competencies and outcomes such as skills, knowledge, and attitudes (Matlay, 
2006; Sanchez, 2011; 2013), graduate careers (Nabi \& Liñán, 2011; Taatila, 2010), practical learning (Rae, 2005), and competitiveness (Jones \& Iredale, 2010) as measures of evaluation of EE.

However, the predominant approach to assess the impact of EE has been to study psychological constructs such as the self-efficacy theory by Bandura (1982) and the Theory of Planned Behavior (TPB) developed by Azjen in 1985 (Azjen, 1991). An increasing number of research projects on EE have focused on entrepreneurship courses and the effect of those courses on students' entrepreneurial intentions (Mueller, 2011; Von Graevenitz et al., 2010). Entrepreneurial models of intention that apply the TPB, has become validated theoretical framework that have shown applicability in different context and settings (Fayolle \& Gailly, 2013; Fayolle \& Liñán, 2013; Mueller, 2011).

Some empirical studies on TPB in EE have mainly focused on the question of whether or not classes in entrepreneurship have an influence in the decision to become an entrepreneurs revealing mixed results (Bae, Qian, Miao, \& Fiet, 2014). On the one hand, some authors have found a positive relationship between EE and entrepreneurial intentions (Fayolle \& Gailly, 2013; Kwon \& Arenius, 2010; Mueller, 2011; Von Graevenitz et al., 2010). On the other hand, others have argued that the relationship is non-existent suggesting that the positive effect is due to the self-selection of the participants who voluntarily take the entrepreneurship course (Hamidi, Wennberg, \& Berglund, 2008; Martin, McNally, \& Kay, 2013).

Literature on EE and models of entrepreneurial intentions show that the TPB is an appropriate assessment tool for measuring effectiveness in EEP (Fayolle, Gailly, \& 
Lassas-Clerc, 2006). However, recent research on entrepreneurial intentions calls for a more systematic and better characterized models of entrepreneurial intention to evaluate EEP (Fayolle \& Liñán, 2013). More research is needed to look at the different components of the EEP in order to understand their relationships. In general, research addressing pedagogical issues in the field of entrepreneurship is still limited (Fayolle, 2013; Matlay, 2010). Only a few researchers are focusing their energy and resources on the subfield of entrepreneurship pedagogy and teaching methods.

Entrepreneurship as a teaching field needs a better understanding of how to best teach entrepreneurship skills and how effective current pedagogies are (Fayolle, 2013). In fact, various scholars claim that the impact of the effectiveness of entrepreneurial pedagogies is still unclear (Fayolle, 2013; Pittaway \& Cope, 2007a). Some argue that pedagogies in EE must be active, experiential, and real world (Neck \& Greene, 2011), but little evidence is provided regarding the accuracy of the relationship between teaching methods and learning outcomes in EEP (Maritz \& Brown, 2013; Mwasalwiba, 2010) or how teaching methods are influenced by the philosophical conceptions by entrepreneurship educators in EE (Hannon, 2006). Along the same lines, according to Fayolle (2013), few articles set out to compare the effectiveness and efficacy of different teaching methods used with the same profile students or with the same type of objectives (Farashah, 2013; Mueller, 2011).

\section{Significance of the Research Problem for Chile}

Research on EE teaching practices and related pedagogical methods in university classrooms is important in many respects for developing countries. Chile is making 
special efforts to improve competitiveness through EE and training. During 2010, the Ministry of Education (MINEDUC) and some public agencies launched a special plan to sponsor EEP at secondary and higher education as well as to attract expert and worldclass early stage entrepreneurs to start their business in Chile. Recently, Chile decided to officially declare 2012 as the year of entrepreneurship and 2013 as the year of innovation. These Chilean initiatives comprised a special plan by the Chilean Government to sponsor entrepreneurship training to reach 10000 higher education students in two years (MINEDUC, 2014). This EE agenda and special training programs have marked a starting point to convert Chile into the definitive innovation and entrepreneurial hub of Latin America and to promote an entrepreneurial society.

Regarding the societal impact of entrepreneurship, it is worth noting that local government, public agencies, and non-profit organizations have pressured companies and businesses to behave in ways that are socially and environmental positive. Being a socially responsible company is one of the major demands that society mandates to new business and markets. Young professionals who will act and think like an entrepreneur or want to become one must achieve those skills in order to be competent and behave ethically. Hence, I believe that the way we teach entrepreneurship in university classrooms impacts how future professionals behave in their companies or in the new business they might create.

There is relatively little research in Chile on EE in the context undergraduate entrepreneurship courses (Albornoz, 2012, 2014). There is even less on the issue of how pedagogical methods used by the entrepreneurship faculty in university classrooms 
influence or not student entrepreneurial intentions. Hence, having a better understanding of how the entrepreneurial learning process allows for a better selection of pedagogical methods is becoming relevant to move forward the frontier of entrepreneurship research in Chile.

\section{Definitions and Key Terms}

In this section I define key concepts and terms relevant to the problem in practice of how to teach entrepreneurship in higher education institutions most effectively.

Entrepreneurial competencies: The competencies are the knowledge, the skills, the attitudes, the values and behaviors that affect the willingness and ability to perform a profession (Middleton \& Donnellon, 2013). Knowledge reflects theoretical knowledge, know-how involves actions and their implementation and interpersonal skills capture a behavioral element (Tounes, Lassas-Clerc, \& Fayolle, 2014).

Entrepreneurial individual: For the purpose of this study, an entrepreneurial individual is defined as people who thinks and acts like an entrepreneur, but not necessarily become an entrepreneurs (who start businesses).

Entrepreneurial intention (EI): Entrepreneurial intention is a psychological construct (commonly used in entrepreneurship research) that refers to the intention to become an entrepreneurial individual or the intentional process to start a business. Intentions have been used to describe a self-prediction to engage in a behavior (Azjen, 1991). In the psychological literature, intentions have proven to be the best predictor of planned behavior, particularly when this behavior is hard to observe (Krueger et al., 2000). 
Entrepreneurial learning: Is an example of a body of knowledge that an individual possesses that implies that the individual knows how to recognize and act on opportunities and interacting socially to initiate, organize, and manage a business (Cope, 2005).

Entrepreneurial or effectual thinking: A mental model (mindset) in entrepreneurship based on the Theory of Effectuation that means to act and think like an entrepreneur, not necessarily become an entrepreneur (Sarasvathy, 2008b).

Entrepreneurial skills: These are the traits that an individual demonstrate that include entrepreneurial thinking (Sarasvathy, 2008a) and behaviors (Krueger, 2007) rather than learning to understand entrepreneurship theories and how to apply them through the process of business creation.

Entrepreneurship course: Any course or class that aims to foster entrepreneurial attitudes and skills, which involves developing certain personal qualities, not exclusively focused on the immediate creation of businesses. This definition covers a wide variety of situations, aims, methods, and teaching approaches (Fayolle et al., 2006a).

$\mathrm{EE}$ (entrepreneurship education): $\mathrm{EE}$ is a process of teaching and learning that implies identifying (creating or discovering), evaluating and acting on opportunities in uncertain environments (Read \& Sarasvathy, 2005; Venkatamaran, 1997). Also, I am referring to EE as the type of education for entrepreneurial attitudes and skills (Bae et al., 2014). 
EEP (entrepreneurship education programs): “Any pedagogical program or process of education for entrepreneurial attitudes and skills, which involves developing personal qualities" (Fayolle et al., 2006a, p. 702)

Entrepreneurship: "The process of discovery, evaluation, and exploitation of opportunities" (Shane \& Venkatamaran, 2000, p. 218)

Pedagogy or teaching methods: The technique used to deliver the curse content and achieve learning objectives (Conti, 2004).

Teaching perspectives: Perspective of teaching are a set of beliefs and intentions that gives direction and justification to educators' teaching actions (Pratt, 1998; 2005).

TPB (Theory of Planned Behavior): This theory postulates three conceptually independent determinants of intention: attitudes toward behavior, subjective norm, and perceived behavioral control.

\section{Summary}

Chapter 1 provides background on the topic of how EE may influence participants' entrepreneurial behaviors and skills. The center of the discussion was to present the problem statement and rationale for this research study, which involves how to teach entrepreneurship in higher education institutions most effectively. In chapter 2 , I present a review of the literature on entrepreneurship in higher education and the conceptual framework that supports this research study. 


\section{CHAPTER 2}

\section{LITERATURE REVIEW}

\section{Introduction}

In chapter 1, I discussed the importance of improving the knowledge about faculty entrepreneurship teaching in entrepreneurship courses at universities. There is not yet a thorough understanding of how instructors in universities are currently teaching entrepreneurship and whether those methods and practices are effective (Fayolle, 2013; Neck \& Greene, 2011). Consequently, entrepreneurship as a teaching field needs a better understanding of how faculty are currently teaching entrepreneurship and how effective current pedagogies are for students.

In this chapter 2, I describe the rationale for selecting the TPB (Azjen, 1991) as a theoretical and methodological framework to assess entrepreneurship courses and programs. Then, I discuss Pratt's $(1998,2005)$ concept of perspectives of teaching in adult education as a tool that describe teachers' beliefs and assumptions about teaching. Finally, I discuss review the literature on EE in the context of higher education. Because this research study was conducted in Chilean universities and is most relevant to that context, I reviewed the most current research available in EE from a global perspective, considering especially literature from Latin America.

Through the discussion and critique of current research literature on EE, I offer a basic rationale for this research study. Despite the fact that a great diversity exists among EE definitions, methods, and pedagogies, there is little consensus about best practices for teaching entrepreneurship in universities (Collins \& Pratt, 2011; Duarte, 2013; Pratt \& Collins, 2000; 2001). As entrepreneurship researchers and educators we face a lack of 
knowledge about the effectiveness of entrepreneurial pedagogies and teaching methods (Baumol, 2012). Recent research argues that in order to design effective entrepreneurship programs, educators in universities should improve their understanding of the different components of any EEP to explore the nature of those relationships and impacts (Fayolle, 2013; Maritz \& Brown, 2013).

This literature review reveals that effectiveness in EE is highly dependent on the coherence and alignment of the educational variables (components) in EEP (Fayolle et al., 2006a; 2006b). The typical components of EEP are the outcomes, the audience, the objectives, the pedagogy, and the assessment (Maritz \& Brown, 2013). The literature generally provides little evidence about the relationship between the efficacy of different pedagogies and these EEP components (Mwasalwiba, 2010). According to Fayolle (2013), few articles set out to compare the effectiveness and efficacy of different teaching methods used with the same profile of students or with the same type of objectives. Hence, determining the relationship between is necessary to evaluating EE impacts. In the following section, I introduce and discuss two theoretical frames: the TPB (Azjen, 1991) and the "perspectives of teaching" in adult education (Pratt, 1998). Both frameworks will help to explain the relationships that might exist between the methods and pedagogies that entrepreneurship educators use in their classrooms and students' perceptions on entrepreneurial intention (Fayolle \& Gailly, 2008). 


\section{Theoretical Frameworks}

In this section, I explain the key aspects of the TPB (Azjen, 1991) as researchbased framework to assess EEP. I develop an argument for choosing this model of entrepreneurial intention from among other models discussed in the EE literature. TPB

According to the literature on EE, the TPB is the model of intention most commonly used in entrepreneurship research to assess effectiveness in EEP (Fayolle \& Gailly, 2013; Fayolle \& Liñán, 2013). The TPB is based on the foundational idea that human behavior is planned and is preceded by intention toward that behavior. Thus, the intention is an accurate predictor of planned behavior (Azjen, 1991). Since the late 1990s, the TPB has become one of the common frameworks used to evaluate EEP and it has contributed to entrepreneurship research from a psychological perspective (Fayolle, 2013).

Krueger and Carsrud (1993) were the pioneers in applying the Azjen's TPB on the field of entrepreneurship. The Azjen's (1991) model posited that education and training can influence students' perception and intentions toward entrepreneurship. According to Krueger et al. (2000), the entrepreneurial activity can be predicted more accurately by studying entrepreneurial intention rather than personality traits, demographic characteristics, or situational factors. The entrepreneurial intention is a psychological construct that precedes a given behavior at the individual level.

The central factor of the Azjen's (1991) model explains the level of intention that an individual has to become more entrepreneurial. Over the last 20 years, this model of 
entrepreneurial intention has received a significant amount of empirical attention in entrepreneurship research but less in the field of the education (Fayolle \& Liñán, 2013). The TPB is used as a model of entrepreneurial intention that predicts a specific behavior. The TPB contends that intentions are a function of three sets of factors: (a) attitudes, (b) subjective norms, and (c) perceived behavioral control. Figure 1 illustrates the three antecedents of intentions that I explain as follow.

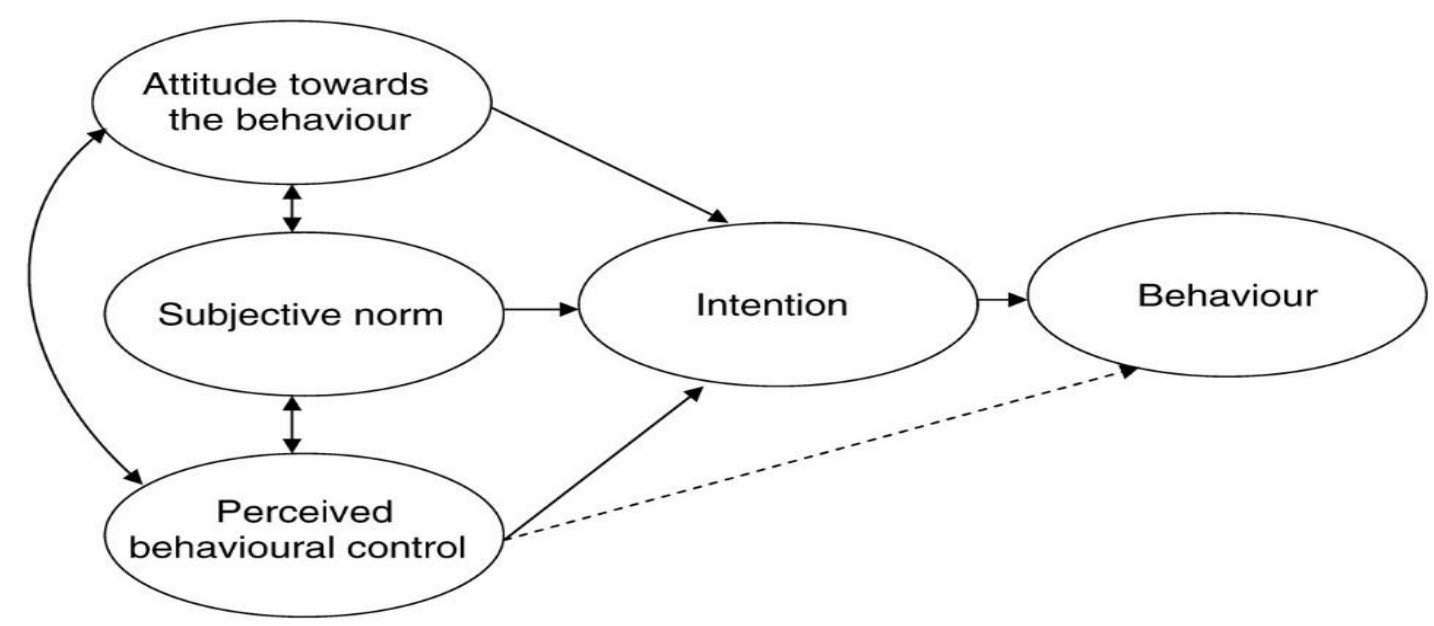

Figure 1. The TPB. Source: Azjen (1991, p. 182).

Attitudes toward behavior: Defined as beliefs and perceptions regarding the personal desirability of performing the behavior, which are in turn related to expectations regarding the personal impact of outcomes resulting from that behavior (Ajzen 1991). When new issues arise requiring an evaluative response, people can draw on relevant information (beliefs) stored in memories (Fayolle et al., 2006a, 2006b).

Subjective norm: Subjective norms or perceived social norms are defined as individuals' perceptions about the values, beliefs, and norms held by people whom they 
respect or regard as important and the individuals' desire to comply with those norms (Azjen, 1991, 2002).

Perceived behavioral control: Perceived ease or difficulty of performing a behavior (Azjen, 1991). According to Fayolle et al. (2006) this concept was introduced into this theory to accommodate the non-volitional elements inherent in all behaviors. The perceived behavioral control is defined as the personal belief about being able to execute planned behavior and the perception that the behavior is within the decision maker's control. It is similar to Bandura's (1986) concept of self-efficacy (Carsrud \& Krueger, 1993).

Fayolle et al. (2006a) described that entrepreneurship researchers have used generally three models of entrepreneurial intention as guidance to measure entrepreneurship outcomes over the last two decades. The three models are: (a) the model of entrepreneurial event by Shapero and Sokol (1982), (b) the model of implementation ideas based on the work proposed by Bird (1989), and (c) the entrepreneurial model of intention based on the TPB (Azjen, 1991; Carsrud \& Krueger, 1993). Next, I briefly explain why the TPB is the best theoretical framework to analyze this study's research problem among the other two models.

Shapero and Sokol (1982) model of intention. This model of intention was the first designed to describe the entrepreneurial process of creating a business. This model viewed the entrepreneurial process of business creation a series of specific steps the entrepreneur can learn. The view of entrepreneurship by this model is a narrow perspective that relates the entrepreneurial process only as startup venture rather than a 
broad concept of entrepreneurship as mindset (Sarasvathy, 2008a). In fact, according to Fayolle and Liñan (2013), Shapero's model "focuses exclusively on the issue of new business creation and not on the evolution or change toward the adoption of some behavior" by potential entrepreneurs. I decided not choose this model due to its narrow focus on business creation, even though this model has been tested and empirically compared to the TPB in entrepreneurship research (Carsrud \& Krueger, 1993).

Model based on the work of Bird (1989). This model was designed as a framework to better understand the implementation of entrepreneurial ideas. The entrepreneurial intentions in this model are seen as "the results of either rational, analytical, cause-effect thinking process or intuitive, holistic, and contextual thinking" (Fayolle et al., 2006a, p. 706). This seems an interesting model to test, especially because it incorporates different perspectives about individual intentions to become an entrepreneur. However, I decided not to choose the Bird's model because, to the best of my knowledge, it has not yet been validated empirically in entrepreneurship research (Fayolle \& Liñán, 2013).

Fayolle et al. (2006a) used the TPB to design, deliver and assess EEP. The authors suggest that some educational variables in EEP such as pedagogical methods, teaching approaches, and type of learning outcomes may affect the students' entrepreneurial intention. Hence, this model of intention can be used as a pedagogical guide and evaluation tool of educational actions (Fayolle \& Gailly, 2008). For instance, researchers from a large German university tested the TPB to investigate whether EE affects intentions to be entrepreneurial in compulsory entrepreneurship classes. The 
authors used ex-ante and ex-post surveys responses from students founded that the course has significant positive effects on students' self-assessed entrepreneurial skills (Von Graevenitz et al., 2010).

Krueger and Carsrud (1993) and Fayolle and Liñán (2013) emphasized that the TPB that can be used to analyze how different types of pedagogies (active versus passive) in EE classes affects the level of students' entrepreneurial intentions. Specifically, educational variables such as pedagogies and learning objectives in EE merit further investigation in affecting the entrepreneurial intention and its antecedents at the student level (Fayolle, 2013).

To understand how educators frame their teaching approaches in EE it is necessary to understand educators' actions, intentions, and beliefs about teaching (Hannon, 2006). Teaching approaches and methods applied in classrooms might be influenced by educators' beliefs and perceptions about teaching and education in general. In the next section, I describe the perspectives of teaching in adult education as a framework to understand how educators see their teaching work .

\section{TPI}

Pratt and Collins (2000, 2001) identified and operationalized five common teaching perspectives in an instrument called the TPI. The TPI measures teachers' profiles on five contrasting views of teaching. A perspective on teaching is "an interrelated set of beliefs and intentions related to knowledge, learning, and the role of a teacher. It is a lens through which we view our work as educators" (Pratt, 2005, p. 3). Each perspective represents a philosophical orientation toward knowledge, learning and 
the social role of teaching. In the adult education setting, the TPI can be used as a discussion tool to guide educators' reflection, to develop statement of teaching philosophy to help educators clarify their perspectives and assumptions, and to provoke discussion for further improvement (Collins \& Pratt, 2011).

Within the TPI there are five perspectives: transmission, apprenticeship, developmental, nurturing, and social reform (Pratt \& Collins, 2000). Each perspective is a singular blend of actions, intentions, and beliefs about teaching. No perspective is viewed as inherently better than any other perspective, even though "being aware of one's perspective may help, but it is not a sufficient indicator of an effective teacher" (p. 372). A summary of the five perspectives of good teaching that the TPI contains is presented in Appendix A.

The TPI can be used to help educators improve their teaching by bringing awareness to their perspective on teaching, because each perspective can represent effective teaching or poor teaching. According to Pratt and Collins (2011), the TPI was conceived as a pluralist instrument to reinforce the idea that there is more than one way to be a good teacher. Also, the TPI can be used in different levels of analysis from an institutional perspective for change, professional development, and as a research instrument.

The TPI has been used for more than 10 years in educational research, providing rich data that has been analyzed by Pratt and Collins (2011). This research showed that the TIP instrument's reliability, validity, and utility exhibits satisfactory psychometric precision in a sample of more than 100,000 respondents in more than 100 countries 
(Collins \& Pratt, 2011). However, some limitations of using the TPI instrument can be appear at the individual and institutional level of analysis. At the individual level, the exclusive focus on the educators' perspectives and beliefs about good teaching represent only one side of the story and experience (Duarte, 2013) and each teaching perspective also holds the potential for poor teaching (Pratt, 2005). Students hold the other side of the story.

In my research study, the TPI provides a baseline of information in the Phase I, quantitative phase of the study. I would like to highlight that the TPI in this study was not considered as a diagnostic tool for the purpose of evaluation. However, the TPI can and will be used as a tool to promote discussion and critical reflection among entrepreneurship faculty to further understand what it mean to teach entrepreneurship to educators through examining their own beliefs and values about teaching.

\section{Concept Map}

The concept map that Figure 2 shows was developed based on the literature review on EE. This conceptual map explains that the TPB can be used as a framework to evaluate EE courses at universities (Fayolle \& Liñán, 2013). According to the literature review in EE, a relationship between the students' entrepreneurial intention and some educational variables in EEP require further research that this present study will plan to investigate. Educational variables in EEP such as the teaching methods used by educators and their perspectives on teaching could be interesting to test.

From the literature review on EE some themes emerged that are relevant to understand entrepreneurship teaching such as the type of teaching approaches currently 
used in EE, the types of learning outcomes, pedagogies and the schools of thought in entrepreneurship, that I discuss in the following sections.

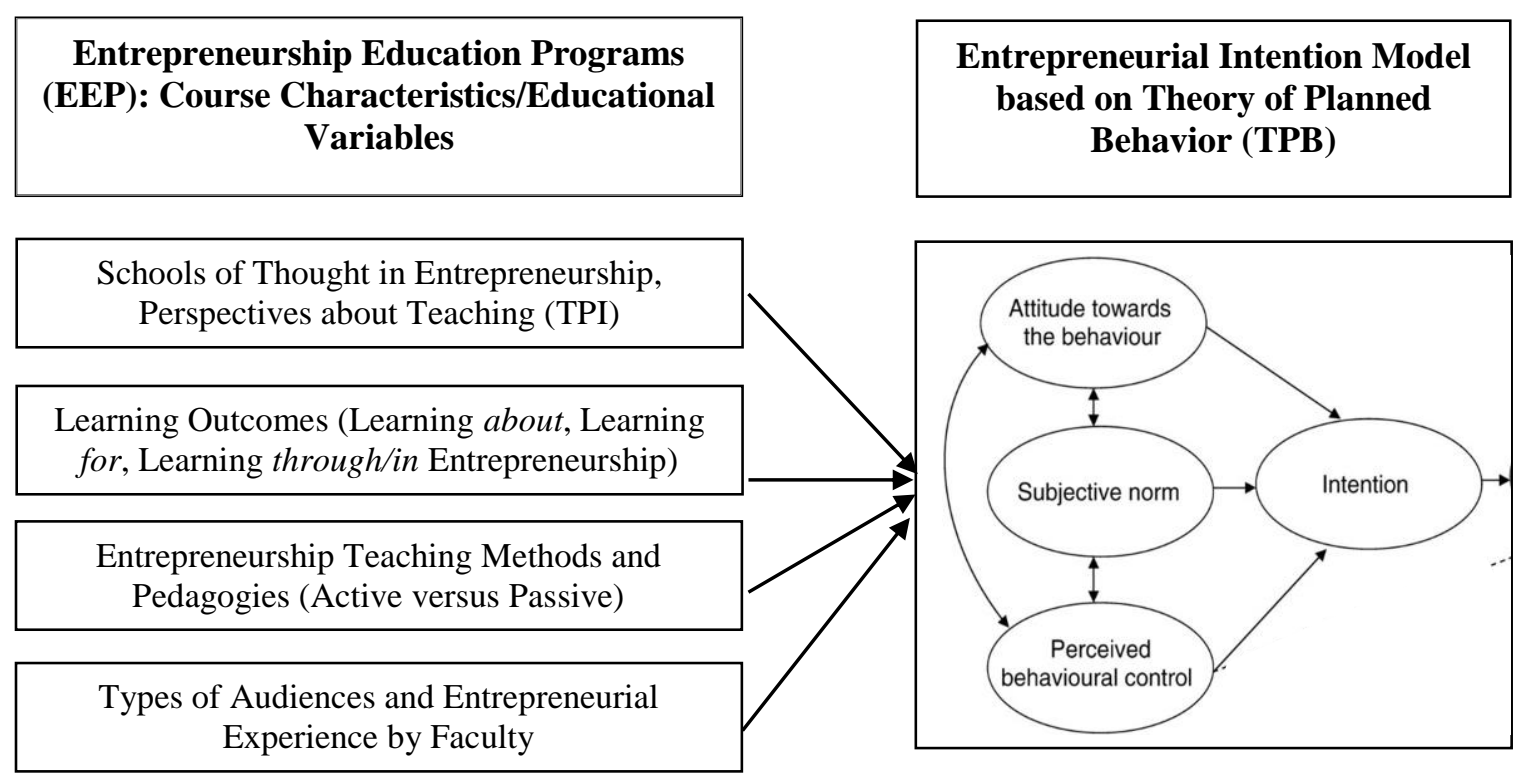

Figure 2. Conceptual map. Adapted from Fayolle et al. (2006a) and Azjen (1991).

\section{Literature Review in Entrepreneurship in Higher Education}

In this section I discuss the themes that emerged in the review of the literature in EE. This section is structure as follows. First, I discuss the different school of thoughts in entrepreneurship research to address an ontological discussion about EE. Second, I provide a description of different teaching models or approaches in $\mathrm{EE}$ at universities. The third theme that emerged from the literature as a relevant part of the entrepreneurship classes are the types of learning goals or outcomes. Finally, I discuss different teaching methods or pedagogies commonly used in EE, to conclude with a discussion of methodological literature relevant in EE at Universities. This chapter ends with a brief summary of its content. 
Entrepreneurship teaching is gaining recognition as an academic subject (Fayolle, 2013) but it is still in its infancy as a field of research (Haase \& Lautenschlager, 2011). The main reason is the abundant heterogeneity of entrepreneurship definitions, content, objectives, and pedagogies in university programs and courses (McMullan \& Long, 1987; Neck and Green, 2011) make entrepreneurship challenge to teach. In fact, few entrepreneurship educators are conducting research in entrepreneurship teaching (Fayolle, 2013). EE is evolving permanently (Maritz \& Brown, 2013) and there is little agreement about what are best practices or teaching approaches most effective for the learning outcomes that educators have for their courses. Finding coherence and consistency between teaching and learning practices in entrepreneurship is relevant to move the field forward (Kyro, 2008).

Research on EE has largely failed to consider the reasons behind the teachers' behaviors and pedagogical approaches for teaching (Fayolle, 2013; Hannon, 2006). For instance, Kember (1997) reviewed 13 articles about faculty's conceptions of teaching from an international perspective and argued that "teaching approaches are strongly influenced by the underlying belief of the teacher" (p. 255). According to the literature, good teaching in higher education contexts showed different perspectives and frameworks for the teaching practice (Kember). The topic of good teaching practices went through a shift in its scholarly discussion (Duarte, 2013), moving since the 1980s from a skills-based framework, that focused on specific strategies and tips, toward a framework based on principles of teaching informed by educators' beliefs and assumptions about education (Pratt \& Collins, 2000). Those principles support the idea 
that there are different ways to teach at universities (Collins \& Pratt, 2011), the point in this context is to find coherence between the teaching beliefs, teaching practices and the learning outcomes.

From the literature review on EE emerged that relationships between educators' beliefs and pedagogical actions needs further research (Fayolle \& Gailly, 2008; Pittaway \& Cope, 2007b). Some argue that understanding the philosophies of teaching rather than focusing exclusively on pedagogical approaches seems to be important if measures to enhance the quality of teaching are to have any impact (Kember, 1997). In like fashion, educators' teaching intentions and actions are result from the underlying beliefs they have about philosophical paradigms about education (Norton, Richardson, Hartley, Newstead, \& Mayes, 2005), and the relevant theories from the disciplines they teach (Béchard \& Grégoire, 2005).

How we define entrepreneurship impacts how we teach it as a discipline (Fayolle, 2013; Hannon, 2006). Hence, it is important to notice that teaching entrepreneurship effectively in the university requires a clear understanding about how we as educators see education, define the phenomenon of entrepreneurship, and understand teaching and learning in entrepreneurship as an academic discipline (Fayolle \& Liñán, 2013). Nowadays, exists different theories of entrepreneurship. Those theories seen and define the nature entrepreneurship different, then, those views translate different into entrepreneurial behaviors, and have practical implications for entrepreneurship teaching (Fisher, 2012). In the following section, I discuss the different schools of thought in entrepreneurship research. 


\section{Schools of Thought in Entrepreneurship Research}

The domain of entrepreneurship consists of the study of opportunities for value creation (Venkatamaran, 1997). Traditional theoretical perspectives of entrepreneurship research see entrepreneurship as the process of identifying and exploiting opportunities (Shane \& Venkatamaran, 2000). Two major schools of thoughts about entrepreneurship currently co-exist under this traditional view of research entrepreneurship. Schumpeter (1934) and Kirzner $(1978,1979)$ are two major authors that have influenced the ontological discussion about entrepreneurship (Fisher, 2012). In the entrepreneurship literature, these authors have contrasting views about how entrepreneurial opportunities come about. The opposite points of views relates to the question of whether opportunities are discovered/founded or created/made (Venkatamaran, Sarasvathy, Dew, \& Forster, 2012). Therefore, the distinction between Schumpeterian and Kirznerian or Austrian school of entrepreneurship might influence the way entrepreneurship is taught because both perspectives understand entrepreneurial knowledge and entrepreneurial learning differently (Wang \& Chugh, 2014).

\section{Traditional Theories in Entrepreneurship Research}

On one hand, Schumpeter's (1934) perspective of entrepreneurship argues that the entrepreneur is an innovator who creates or discover something new to break the market equilibrium. Schumpeter describes entrepreneurship as a process of creative destruction that implies the entrepreneur generates change through innovation to provoke a new equilibrium in the market (Schumpeter, 1934). This philosophical point of view commonly named the creation approach is predominant in European entrepreneurship 
research and relates to the interpretative social constructivist school of thought, which postulates in this context, that opportunities emerge as a results of the entrepreneurs' perceptions, interpretation, and understanding of the market environment (Wang \& Chugh, 2014).

Schumpeterian perspective seen the entrepreneur as a person who creates opportunities to generate social, environmental, and economic value through the process of doing something that is outside of the range of the existing practice (Gibb, 2002). The entrepreneurs is a creative person who have developed different entrepreneurial skills used in uncertainty to create and produce an opportunity that did not exist. In context of the education and training, entrepreneurial skills are best developed using learning by doing and experiential learning activities that emphasizing creativity, reflection practice, and team building (Gibb, 1996; Krueger, 2007; Pittaway \& Cope, 2007a).

On the other hand, Kirzner $(1978,1979)$ view entrepreneurs as those who are on permanent alert to recognize opportunities in uncertainty, to then, exploit those business opportunities to restore the market equilibrium. Kirznerian school of thought, also named as the discovery approach toward entrepreneurship (Alvarez \& Barney, 2007), is predominantly among North American researchers. These scholars tend to follow a positivist school of thought that assumes that entrepreneurs find opportunities that already exist out there in the environment, waiting to be discover or found, independent of the entrepreneurs' mind (Molina-Azorin et al., 2012). The entrepreneurs have the ability to see a disequilibrium or a gap in the market. Hence, the Kirznerian School on entrepreneurship suggests that entrepreneurs should capture opportunities that already 
exist in the environment through the development of management and business skills in potential entrepreneurs.

\section{Emerging Theories in Entrepreneurship Research}

Over the last decade, these traditional theoretical perspectives in entrepreneurship research have contrasted with two emerging theories of entrepreneurial opportunities developed specifically to the entrepreneurship domain and not adopted from other disciplines. The entrepreneurial bricolage perspective (Baker \& Nelson, 2005) and the effectuation theory (Sarasvathy, 2008a). Both theories of entrepreneurship describe the phenomenon as a process of creation in general from ideas and processes to businesses and markets. It is worth noting that both theories are not restricted just of the process of business-venture formation (Fisher, 2012).

The theory of bricolage has been used in entrepreneurship research in terms of describing market creation. The term of bricolage is defined as "making do by applying combinations of resources at hand to new problems and opportunities" (Baker \& Nelson, 2005 , p. 33). In an entrepreneurial context, the theory of bricolage suggests that the entrepreneur creates something from nothing, combining resources that are constrained for new purposes, inspiring creativity and innovation. According to Fisher (2012) the theory of bricolage rests on the concept that the resources in the environment are socially constructed and it has been used to explain relationships between the design processes and innovation in environments or scenarios that are uncertain and dynamic. This theory is appropriated to EE but with little empirical attention in entrepreneurship teaching (Fisher, 2012). 
The theory of effectuation is considered as an emergent perspectives in entrepreneurship in terms of creation process (Fisher, 2012). Effectuation theory has contributed to the body of the literature on entrepreneurial behavior and it has been considered a paradigm shift in the way entrepreneurship is understood (Perry, Chandler, \& Markova, 2011). This emergent theoretical perspective argue that the phenomenon of interest, in this case -the entrepreneurship process-, should be considered as an "artifact" that is not only to be studied but something to be designed. Effectuation theory is based on the work of Herbet Simons, who claims that entrepreneurship research should be considered as a "science of the artificial" (Venkatamaran et al., 2012, p. 24), that needs to move away from the notion of entrepreneurship as a social science; mainly interested in providing causal explanation of the phenomenon (Sarasvathy, 2008b) to a notion of entrepreneurship as a method that can provide innovative solutions to current problems in uncertain environments (Neck \& Greene, 2011).

Sarasvathy's (2008a) seminal work on effectuation theory explains this theoretical perspective in terms of the entrepreneurship behavior. In details, the theory of effectuation suggests that entrepreneurs focus their process of creation on a set of means at the personal level including: personal knowledge (what I know), personal skills (who I am), and social networks (who I know) under conditions of uncertainty (Fisher, 2012; Sarasvathy, 2008a). Entrepreneurs adopt a type of reasoning or thinking named "effectual thinking or effectuation" by Sarasvathy, instead of the conventional approach of "strategic thinking" or causation which is currently used in business and EE (Sarasvathy, 2008a, p. 2). According to Sarasvathy (2008b), entrepreneurs use the effectuation 
approach to take actions based on the notion that inputs such new information, networks, and resources expand the available opportunities especially when the future is uncertain and unpredictable as entrepreneurship is.

Conversely, causation is a more traditional view of entrepreneurship, commonly based on strategic planning and consistent with the discovery approach of entrepreneurship by Kirszner or the creative approach of entrepreneurship by Schumpeter (Fisher, 2012). The causation thinking or approach to learn and teach entrepreneurship is based on the conventional strategic thinking used by managers and business people (Sarasvathy, 2008a).

To illustrate the abstract concepts of effectuation and causation in terms of the teaching practice, Greenberg et al. (2011) described a teaching activity that enables students -from any course- to experience the difference between both ways of thinking. The authors use two contrasting metaphors, a "quilt" and a "puzzle" to explain both concepts (p. 27) in entrepreneurship teaching. The quilt exemplifies the effectuation approach through designing the quilt from assorted fabric and the puzzle represents the traditional view of causation approach through assembling the puzzle from jigsaw pieces. These pedagogical approaches in entrepreneurship have not yet been tested in classrooms experiences to evaluate their impacts (Perry et al., 2011).

Bricolage and effectuation theories show similarities in terms of that existing resources serve as a source of entrepreneurial opportunities and that considering resource constraints is a source of creative innovations (Fisher, 2012). In fact, some scholars argue that researchers and educators in EE should consider study entrepreneurship through new 
emergent theories such as bricolage or effectuation, because both theories can be applied in classrooms activities and can be learned by anyone (Makimurto-Koivumaa \& Puhakka, 2013; Perry et al., 2011).

In sum, theories of entrepreneurship and how those decisions translate into entrepreneurial behaviors, have practical implications for entrepreneurship research and teaching (Fayolle, 2013). Under conditions of uncertainty, effectuation and bricolage seems to work better for entrepreneurs (Fisher, 2012; Sarasvathy, 2008b). Fisher (2012) and Makimurto-Koivumaa and Puhakka (2013) suggest that traditional entrepreneurship perspectives in teaching entrepreneurship need to be combined with emergent theories such as effectuation and bricolage. Traditional or causal model of entrepreneurship failed to explain the actual behavior of entrepreneurship process in a dynamic and uncertain environment.

\section{Teaching Approaches in EE}

At this time, there are diverse philosophical perspectives about how we define and teach entrepreneurship and there is not a single entrepreneurship teaching approach used in universities (Neck \& Greene, 2011). The use of EE teaching approaches or frameworks by entrepreneurship educators is relevant to move the research on entrepreneurship teaching forward. Awareness of teaching models in EE might help educators reflect about how they see EE and how those conceptions translate into what they are really doing in their classrooms.

Béchard and Grégoire (2005) were the first to add to the discussion among teaching models, the elements of how entrepreneurship is taught. Previously, the focus 
was only on what was taught not how it was taught. The authors defined the teaching model in EE as a model that aligns the ontological and operational dimensions that educators make explicit in their general and educational assumptions about teaching. Additionally, they look at how those ontological dimensions translate at the level of teaching actions. In fact, the authors pointed out that teaching models might help to understand the link between the conceptions that educators have about teaching and their actual teaching behavior. The ontological and didactical levels of analysis in a teaching model require coherence and alignment, and both are crucial to understanding what constitutes good teaching (Fayolle \& Gailly, 2008).

Béchard and Grégoire (2005) and Fayolle (2013) argued that incorporating into the discussion the reasons that motivate an educator's particular educational choice in any entrepreneurship teaching model is critical for improvement. Because different beliefs about education impact teaching classrooms practices and diverse types of learning outcomes in EE requires different methodological and pedagogical approaches to deliver effective instruction (Hannon, 2006).

Table 1 illustrates three different models or archetypes for teaching at the higher education level developed by Béchard and Grégoire (2005) based on the discussion of different philosophies of education at the ontological level and the operational or didactical level. The authors identify three teaching models or archetypes: (a) the supply model, 9b) the demand model, and (c) the competence model. 
Table 1

Teaching Models for Entrepreneurship in Higher Education

\begin{tabular}{|l|l|l|l|}
\hline Ontological level & The Supply Model & The Demand Model & The Competence Model \\
\hline $\begin{array}{l}\text { Philosophical } \\
\text { Paradigm }\end{array}$ & Objectivist & Subjectivist & Interactionist \\
\hline Theoretical Bases & $\begin{array}{l}\text { Behavioral Psychology } \\
\text { Reproduction theory (in } \\
\text { sociology of education) }\end{array}$ & $\begin{array}{l}\text { Humanistic Psychology } \\
\text { Human capital (in } \\
\text { economy of education) } \\
\text { Social and personality } \\
\text { psychology }\end{array}$ & $\begin{array}{l}\text { Cognitive Psychology } \\
\text { Socio-historical } \\
\text { psychology } \\
\text { Situated cognition theory }\end{array}$ \\
\hline $\begin{array}{l}\text { Educator's } \\
\text { about Teaching }\end{array}$ & $\begin{array}{l}\text { To teach is to impart } \\
\text { information. Teaching as } \\
\text { telling a story }\end{array}$ & $\begin{array}{l}\text { To teach is to assure the } \\
\text { knowriation of } \\
\text { organizing students } \\
\text { activities }\end{array}$ & $\begin{array}{l}\text { To teach is to converse } \\
\text { with the students about the } \\
\text { knowledge. Teaching is } \\
\text { making learning possible }\end{array}$ \\
\hline $\begin{array}{l}\text { Educator's } \\
\text { Conceptions } \\
\text { about Themselves } \\
\text { and the Students }\end{array}$ & $\begin{array}{l}\text { A teachers is a facilitator } \\
\text { presenter/students are } \\
\text { passive recipients }\end{array}$ & $\begin{array}{l}\text { And tutor/students are } \\
\text { participants } \\
\text { developer/students are } \\
\text { active participants in the } \\
\text { co-construction of their } \\
\text { knowledge }\end{array}$ \\
\hline
\end{tabular}

Note: Adapted from Béchard and Grégoire (2005, p. 5)

These three models consider not only different conceptions about philosophy of education and pedagogical choices by educators, but also the actions implemented in classrooms such as teaching goals, pedagogical methods, the evaluation forms and the links between them. However, the authors do not make a clear distinction between teaching practices and learning outcomes in each teaching model.

Béchard and Grégoire (2005) claimed that no model of teaching is superior to the other and they help educators identify and reflect on the different dimension of education and the coherence of their own teaching practices. It could be very interesting to further analyze connections between philosophies about education based Pratt's (1998) TPI and the entrepreneurship teaching models by Béchard and Grégoire. In fact, making explicit the relationships between different educational variables in entrepreneurship courses is 
relevant for future research (Maritz \& Brown, 2013). For instance, exploring the influence that educators' teaching archetypes might have on students' learning is beneficial to evaluate the impact of EEP on learning outcomes (Kember \& Gow as cited in Béchard \& Grégoire, 2005; Kyro, 2008).

Despite the value of these three models by Béchard and Grégoire (2005) more research is needed to evaluate the consistency among different teaching models in EE and to find coherence between the basic concepts and foundations about education, pedagogies, and outcomes (Fayolle, 2013; Haase \& Lautenschlager, 2011; Kyro, 2008). In fact, Kyro (2008) proposed a competency-based approach to teaching and learning in EE; similar to competence model by Béchard and Grégoire (2005). The author claims that a competency-based frame could be a good structure for planning, conducting, and evaluating EEP, especially for those programs that have the goals for students to act and think like entrepreneurs (Sarasvathy, 2008a).

Even though entrepreneurial teaching and learning is a complex phenomenon, research on assessing teaching approaches in EE and the corresponding learning outcomes is still limited (Haase \& Lautenschlager, 2011). In sum, Béchard and Grégoire (2005) characterized each of these models for EE, but they argue that more research is needed to explore the link between the ontological dimensions that motivate particular pedagogical and the operational choices to make them explicit and find coherence (Kyro, 2008).

Entrepreneurship teaching is an evolving field. Indeed, EE has moved from a focus on teaching as process-based model to a focus on entrepreneurship as a learning 
process that takes into account not only the creation of new ventures but also the competences and behaviors that entrepreneurs poses (Kyro, 2008).

Recently, Neck and Greene (2011) made a classification of approaches for teaching entrepreneurship at the university level. The authors identified four different teaching approaches in EE depending on the purpose, the topics selected, and some pedagogical implications. The four teaching approaches are: (a) the entrepreneur world (EW), (b) the entrepreneurial process (EP), (d) the entrepreneurial cognition (EC), and (d) the entrepreneurial method (EM). All the approaches are presented in Table 2.

The four EE teaching approaches by Neck and Greene (2011) represent changes that EE has experienced over the last 30 years. The first three entrepreneurship teaching approaches (EW, EP, EC) represent more process-oriented methods which mean that educators in this approach tend to use traditional entrepreneurial pedagogies (Gibb, 2002). Traditional entrepreneurial pedagogies (Mwasalwiba, 2010; Maritz \& Brown, 2014) tend to emphasize the transmission and reproduction of knowledge and application of procedures (e.g., lectures, teaching hard facts, reading print materials, using case studies, and business plans as a way to simulate business creation process).

In contrast to the first three approaches shown in Table 2, the fourth entrepreneurship teaching approach, called EM, is considered more action-based and experiential in nature, thus it is considered more innovative in terms of the pedagogies used in classrooms (Gibb, 2002; Hindle, 2007). Neck and Greene (2011) explained that the EM method might require a set of different non-traditional approaches to teaching and learning in entrepreneurship such as the use of games, simulations, guest speakers, 
the incorporation of uncertainty and ambiguity in classroom activities, and fostering learning from failure (Wang \& Chugh, 2014).

Table 2

Entrepreneurship Teaching Approaches

\begin{tabular}{|c|c|c|c|c|}
\hline $\begin{array}{l}\text { Teaching } \\
\text { Approach }\end{array}$ & $\begin{array}{l}\text { Entrepreneur } \\
\text { World (EW) }\end{array}$ & $\begin{array}{l}\text { Entrepreneurial } \\
\text { Process (EP) }\end{array}$ & $\begin{array}{l}\text { Entrepreneurial } \\
\text { Cognition (EC) }\end{array}$ & $\begin{array}{l}\text { Entrepreneurial } \\
\text { Method (EM) }\end{array}$ \\
\hline $\begin{array}{l}\text { Level of } \\
\text { Analysis }\end{array}$ & $\begin{array}{l}\text { Entrepreneur as } \\
\text { individual. }\end{array}$ & $\begin{array}{l}\text { Business as a new } \\
\text { organization. }\end{array}$ & $\begin{array}{l}\text { Entrepreneur and } \\
\text { the team. }\end{array}$ & $\begin{array}{l}\text { Entrepreneur, } \\
\text { business, and the } \\
\text { team. }\end{array}$ \\
\hline $\begin{array}{l}\text { Main Focus } \\
\text { and Topics }\end{array}$ & $\begin{array}{l}\text { The knowledge of } \\
\text { Entrepreneur traits, } \\
\text { entrepreneurship } \\
\text { theories and } \\
\text { models. }\end{array}$ & $\begin{array}{l}\text { The process of new } \\
\text { business creation. }\end{array}$ & $\begin{array}{l}\text { The process of new } \\
\text { business creation } \\
\text { and the process of } \\
\text { decision-making to } \\
\text { engage in } \\
\text { entrepreneurial } \\
\text { activity. }\end{array}$ & $\begin{array}{l}\text { The use of a } \\
\text { portfolio of } \\
\text { techniques to } \\
\text { practice } \\
\text { entrepreneurship } \\
\text { and think } \\
\text { entrepreneurially. }\end{array}$ \\
\hline Purpose & $\begin{array}{l}\text { Emulate } \\
\text { entrepreneurial } \\
\text { knowledge } \\
\text { (entrepreneurs' role } \\
\text { model and } \\
\text { mentality). }\end{array}$ & $\begin{array}{l}\text { Replicate EP to } \\
\text { make } \\
\text { entrepreneurial } \\
\text { decisions. }\end{array}$ & $\begin{array}{l}\text { Decide whether to } \\
\text { become and } \\
\text { entrepreneurs and } \\
\text { decide how to } \\
\text { make decision as } \\
\text { an entrepreneur. }\end{array}$ & $\begin{array}{l}\text { Adopt } \\
\text { entrepreneurial } \\
\text { behaviors and } \\
\text { achieve individual } \\
\text { personal potential. }\end{array}$ \\
\hline $\begin{array}{l}\text { Types of } \\
\text { Pedagogies }\end{array}$ & $\begin{array}{l}\text { Lectures, seminars, } \\
\text { assessments, and } \\
\text { guest speakers. }\end{array}$ & $\begin{array}{l}\text { Cases studies, } \\
\text { writing business } \\
\text { plans in teams. }\end{array}$ & $\begin{array}{l}\text { Cases studies, } \\
\text { scripting, and } \\
\text { simulation of } \\
\text { business creation } \\
\text { process in teams. }\end{array}$ & $\begin{array}{l}\text { Serious games, } \\
\text { observations, } \\
\text { practice, reflection, } \\
\text { and problem-based. }\end{array}$ \\
\hline $\begin{array}{l}\text { Pedagogical } \\
\text { Implications }\end{array}$ & $\begin{array}{l}\text { Description } \\
\text { (Of the } \\
\text { entrepreneur and } \\
\text { the field). }\end{array}$ & $\begin{array}{l}\text { Prediction } \\
\text { (New opportunities } \\
\text { and planning new } \\
\text { business). }\end{array}$ & $\begin{array}{l}\text { Decision } \\
\text { (Thinking and } \\
\text { doing as } \\
\text { entrepreneurs). }\end{array}$ & $\begin{array}{l}\text { Action and } \\
\text { Encouraging } \\
\text { reflection to value } \\
\text { creation in } \\
\text { different levels: } \\
\text { personal, social and } \\
\text { economic. }\end{array}$ \\
\hline
\end{tabular}

Note. Adapted from Neck and Greene (2011) and O'Connor (2012).

In contrast to the traditional view of $\mathrm{EE}$ as a process-oriented approach, entrepreneurship as an action-based approach implies being creative and iterative in the classroom (Sarasvathy, 2008b) and requires experimentation and reflective practice (Neck \& Greene, 2011). For instance, a recent research article by Mäkimurto-Koivumaa 
and Puhakka (2013) proposed the theoretical perspective of effectuation (Sarasvathy, 2008b) as a new pedagogic in EE. This effectuation-based EE built on action-based learning methods such as problem-based or inquiry-based learning, could lead to a higher rate of entrepreneurial activity. However, the effectuation-based EE as a pedagogy need further empirical research to evaluate its impacts (Perry et al., 2011).

Gibb (2002) claimed that traditional teaching methods or pedagogies such as are suggested by the first three teaching approaches (Neck \& Greene, 2011), do not activate entrepreneurship because they might inhibit the development of entrepreneurial attitudes and skills in students (Krueger, 2007). Therefore, moving toward understanding entrepreneurship as a method using for instance experiential and action-based pedagogies, is a fundamental feature of EE (Neck \& Greene, 2011). Innovative pedagogies may help improve how we are currently teaching entrepreneurship in universities and how we see and investigated entrepreneurial opportunities (Fisher, 2012). Even though these four approaches by Neck and Greene have contributed to the discussion of how to teach entrepreneurship at the university level, the authors do not explicitly connect pedagogical decisions made by the educator to the conceptions and beliefs about education and entrepreneurship and how those influence their teaching behaviors in classrooms.

In the next section, I provide a clear distinction between the different types of learning entrepreneurship that already exists EE from the literature. Understanding the learning typology in EE, helps to align students' learning outcomes with the teaching and pedagogies used in classrooms. 


\section{Types of Learning in EE}

Different theories of learning in EE have been discussed over the last decade (Cope, 2007; Politis, 2005). Entrepreneurial learning is known as a learning process in entrepreneurship that includes both implicit and explicit knowledge to solve complex problems and making entrepreneurial decisions in uncertain environments (Fayolle, 2013). Entrepreneurial learning means learning to recognize and act on opportunities and interacting socially to initiate, organize, and manage business (Cope, 2005). Others view learning in entrepreneurship as a process of co-participation (Heinonen \& Pokkijoki, 2006). However, an emergent and transversal concept of entrepreneurial learning in educational context advocates for a learning can be acquired and experimented by students in an appropriate classroom environment in which the educator apply teaching methods that train students to develop an entrepreneurial perspective, mindset, and skills (Sarasvathy, 2008b; Krueger, 2007).

Fayolle (2007) and Gibb (2002) were pioneers in identifying and discussing different categories of entrepreneurial learning (i.e., entrepreneurial goals, outcomes, objectives or aims as interchangeable terms). Entrepreneurship courses and programs present different objectives or aims, thus educators generally face challenges in delivering the subject if they do not have a clear understanding about the type of learning the educator wants to deliver to students. According to Fayolle (2008) entrepreneurship educators have to first identify the right conditions and factors to implement their programs and enhance student learning. 
One of these conditions is to identify what kind of learning process in EE the educator wants to implement and deliver to students and for what purpose (Fayolle \& Gailly, 2008). Through the identification of various learning goals, educators might have a deeper understanding of educational needs as well as more weighted choice of evaluative criteria and pedagogical techniques (Alberti, Sciascia, \& Poli, 2004). The most commonly cited learning goals for EE by previous studies (Gibb, 2002; Fayolle, 2013; Fiet, 2001; Kozlinska, 2012; Krueger, 2007; Martiz \& Brown, 2013; Mwasalwiba, 2010) are: (a) learning about entrepreneurship, (b) learning for entrepreneurship, and (c) learning through entrepreneurship. These learning typologies are explained in detail in Table 3.

Learning about entrepreneurship: to acquire knowledge, raising awareness, knowledge and understanding about EE concept and practice. To understand entrepreneurship.

Learning for entrepreneurship: to acquire skills in the use of techniques and in the analysis of business situations and in the synthesis of action plans to then, develop personal self-confidence and capability to start-up. To become an entrepreneur and continuing education for entrepreneurs.

Learning through/in entrepreneurship: to acquire entrepreneurial skills and thinking that enable students to act and think like an entrepreneur not necessarily become one. To become an entrepreneurial-enterprising individual. 
Table 3

Learning Processes in EE

\begin{tabular}{|c|c|c|}
\hline Learning process & Key dimensions & Relevant concepts and theories \\
\hline $\begin{array}{l}\text { Learning about entrepreneurship or } \\
\text { Learning to become an } \\
\text { academic/teacher in EE }\end{array}$ & $\begin{array}{l}\text { Theoretical Dimensions about } \\
\text { the phenomenon as an academic } \\
\text { subject } \\
\text { Entrepreneurial knowledge }\end{array}$ & $\begin{array}{l}\text { Entrepreneurship as a research } \\
\text { domain (Fisher, 2012) }\end{array}$ \\
\hline $\begin{array}{l}\text { Learning for entrepreneurship or } \\
\text { Learning to become an } \\
\text { entrepreneurs }\end{array}$ & $\begin{array}{l}\text { Entrepreneurship as a broad } \\
\text { concept } \\
\text { Professional/practical } \\
\text { dimensions (know what, know } \\
\text { how, and know who), business } \\
\text { creation process } \\
\text { Learning by doing }\end{array}$ & $\begin{array}{l}\text { Effectuation (Sarasvathy, 2008a) } \\
\text { Learning by trying } \\
\text { Cognitive models (Krueger, } \\
\text { 2007) }\end{array}$ \\
\hline $\begin{array}{l}\text { Learning through-in } \\
\text { entrepreneurship or } \\
\text { Learning to become an enterprising- } \\
\text { entrepreneurial individual }\end{array}$ & $\begin{array}{l}\text { Entrepreneurship as a process } \\
\text { of creation and action } \\
\text { Spiritual dimensions (know } \\
\text { why and know when) } \\
\text { Enterprising/entrepreneurial } \\
\text { attitudes and skills }\end{array}$ & $\begin{array}{l}\text { Entrepreneurial intention (Azjen, } \\
\text { 1991) } \\
\text { Entrepreneurial orientation } \\
\text { (applied at the individual level) }\end{array}$ \\
\hline
\end{tabular}

Although there is a blurred line in EEP regarding these entrepreneurial learning typology (Mwasalwiba, 2010), literature on teaching and learning in EE suggests that effectiveness in programs highly depend of the coherence between the components of the program such as the learning outcomes and teaching practices (Maritz \& Brown, 2013). Indeed, Kozlinska (2012) pointed out that it is difficult to find an EEP that sets only on the first objective, it is rather a combination of two-three learning goals.

These three types of learning have received some empirical support (Hytti \& O’Gorman (2004) in Maritz \& Brown, 2013). These results show that through a revision of $50 \mathrm{EEP}$, most of them were designed to help individuals learning for entrepreneurship, followed by programs to help individuals understand about entrepreneurship and last, 
become entrepreneurial to act and think as entrepreneurs. Even though distinguish the learning typology of the EEP is relevant, there still a limited understanding of how to best achieve these objectives (Wang \& Chugh, 2014).

While the variation of objectives and methods for EE is significant, most entrepreneurship educators deliver a combination of the three main interpretations of entrepreneurial learning. Conceptions and approaches for teaching entrepreneurship vary and might provoke some confusion in the way entrepreneurship is taught. It is challenge for entrepreneurship educators to choose the teaching methods or pedagogic that align to their course objectives, the context, and the type of students in their programs (Fayolle, 2013). However, students must learn not only about and/or for entrepreneurship, but also through/in entrepreneurship in order to adopt entrepreneurial behaviors (Balan \& Metcalfe, 2012; Fayolle \& Gailly, 2008; Kirby, 2004; Neck \& Greene, 2011; Read \& Sarasvathy, 2005).

In the next section, I expand the description of the three typologies of learning in entrepreneurship. First, I explain why learning about entrepreneurship is considered a conventional teaching approach to develop entrepreneurial skills to then move the learning for and through/in entrepreneurship.

\section{Learning About Entrepreneurship}

Learning about entrepreneurship emphasizing theoretical foundation on the entrepreneur-as-individual as well as focusing on entrepreneurial content absorbed by the student (Neck \& Greene, 2011). The best way to describe how learning takes place in this approach is learning about entrepreneurship which means learning entrepreneurship 
content, theories and models. This type of learning emphasizes the entrepreneur's role in the creation of businesses as well as the individual characteristics of the successful entrepreneur. This emphasis is problematic because it avoids developing entrepreneurial skills and thinking known as the soft-skills such as creativity, innovation, risk-taking, and problem solving (Gibb, 2002).

The aim of educating about entrepreneurship is to have students obtain a general understanding of entrepreneurship as a phenomenon rather than training students to cultivate opportunity discovery skills (Mwasalwiba, 2010). Entrepreneurship educators that pursue this learning goal probably see knowledge as an accumulation of data, facts, and content about entrepreneurship and this type of knowledge concurs with a behaviorist theory based on the acquisition of information such as hard facts of entrepreneurship and business market (Krueger, 2007). Gibb (2002) supported my arguments by claiming that entrepreneur knowledge as content knowledge is objective, fact-based, and is often behaviorist in nature because this kind of knowledge does not produce the entrepreneurial skills and abilities that the students need.

Learning about entrepreneurship might not help students in developing entrepreneurial skills and procedures required in EE (Gibb, 2002). Unfortunately, learning about entrepreneurship mostly focuses on teaching entrepreneurial behavior, which includes the personal characteristics and individual profile that a successful entrepreneur must have. According to O'Connor (2012), it might be risky using ideal profiles of successful entrepreneurs because there is a possibility of excluding some students who do not meet these standards and behaviors. The entrepreneurial learning 
that students need to be taught is more than the understanding and emulation of entrepreneur knowledge; students need to learn how to act as entrepreneurs making entrepreneurial decisions (Krueger, 2007; Sarasvathy, 2008a).

\section{Learning for Entrepreneurship}

Learning for entrepreneurship is a concept developed by Gibb (2002) that means learning to infuse entrepreneurial skills and behaviors into students to become entrepreneurs. In this type of learning knowledge is seen not only as accumulation of data and content, but also as analyzing theoretical or content knowledge (stages of the business creation) through experiential knowledge (writing business plans). Learning for entrepreneurship moves away from entrepreneur behaviors and traits as to a more cognitive domain about entrepreneurship (Neck \& Greene, 2011).

There is little research about how the cognitive research on entrepreneurship will contribute to better explain how entrepreneurs identify and exploit opportunities and how they make connections between knowledge, cognition and creativity (Corbett, 2005). Some researchers argue that to better understand the process of entrepreneurship it is important to examine how entrepreneurs think and how they make entrepreneurial decision (Cope, 2005; Corbett, 2005). Effectuation theory could be help in this direction (Sarasvathy, 2008a).

This type of learning focuses on the acquisition of entrepreneurial skills through learning by doing and through thinking entrepreneurially (Pittaway \& Cope, 2007a). However, learning for entrepreneurship approach assumes that the business creation process is linear and predictable and as researchers argue entrepreneurship is nor linear 
neither predictable (Gibb, 2002). Hence, in order to develop skills such as innovation, creativity, and frustration tolerance in uncertain environments that the entrepreneurial learning requires, it is necessary to apply new pedagogies that might encourage reflective practice and learning through entrepreneurship in order to inform further action and a better entrepreneurial learning close to real experiences (Kolb, 1984; 2001; Schön, 1983; 1987).

\section{Learning Through/In Entrepreneurship}

Learning through/in entrepreneurship implies the individual learning process to discover, evaluate and exploit opportunities. This type of learning support the process of becoming an entrepreneurial individual. This means thinking and acting like an entrepreneur in order to encourage the creation of innovative new ways to solve organizational and social issues. Promoting an entrepreneurial mindset or entrepreneurial thinking as well as increasing entrepreneurial skills in university students implies prioritizing learning through-in rather than simply transferring knowledge about or for entrepreneurship (Krueger, 2007). Emergent scholars in EE argues that learning through entrepreneurship should be set at the core of educational practices in terms of entrepreneurship teaching (Fisher, 2012; Makimurto-Koivumaa \& Puhakka, 2013; Neck \& Greene, 2011; Sarasvathy, 2008a).

There is an accepted view that entrepreneurs are action-oriented and that learning occurs through experience and discovery (Pittaway \& Cope, 2007a). Specifically, entrepreneurs learn by doing, by experimenting, and by problem-solving (Cope, 2005; Gibb, 1996). It is worth noting that different types of learning requires different kinds of 
pedagogy. However, despite a particular pedagogy, student learning remains fundamental (Fayolle, 2013). However, in order to foster entrepreneurial learning, skills and thinking in students, the teaching models and pedagogies in EE need to be more innovative than the traditional form used currently (Fayolle \& Gailly, 2008; Kirby, 2004; McMullan \& Long, 1987; Neck \& Greene, 2011; Solomon, Weaver, \& Fernald, 1994).

Some researchers have begun to argue that EE should focus only using innovative teaching methods that encourage learning through entrepreneurship, because it will help students adopt entrepreneurial behaviors (Gibb, 1993; O’Connor, 2012), think entrepreneurially (Sarasvathy, 2008b), and develop a set of entrepreneurial skills and values (Mwasalwiba, 2010; Neck \& Greene, 2011). According to this new trend in entrepreneurial learning at the student level, teaching entrepreneurship is viewed as a toolkit of various pedagogies to help students dealing with uncertainty and complexity that traditional pedagogies do not account for. In the next section, I summarize and discuss the teaching methods or pedagogies most commonly used in EE based on the literature review.

\section{Entrepreneurial Pedagogies in EE}

Some scholars in EE claim that effective teaching entrepreneurship encompasses both the science and the art of entrepreneurship in terms of business creation and opportunity detection (Greenberg et al., 2011; Hannon, 2006; Kirby, 2004). On one hand, the science describes the theoretical and practical knowledge about entrepreneurship, business and management usually using conventional teaching approaches (Fiet, 2001; Rae, 2005). On the other hand, the art of entrepreneurship deals with new ways of 
thinking such as creativity, innovation, and effectual reasoning (Sarasvathy, 2008a) that seems to be more challenging because they require experiential activities (Heinonen \& Poikkijoki, 2006). For instance, Kirby (2004) argued that EE must involve not just teaching the science such as entrepreneurship theories and content knowledge but teaching the art which encompass soft skills such as problem-solving and risk taking that entrepreneurs require making decisions in uncertainty.

From the literature review, effective entrepreneurship teaching for the twenty-first century requires that entrepreneurship educators might chose the specific pedagogical methods that seems to work better with the type of entrepreneurial learning they want students develop. This means that entrepreneurship pedagogies have to embrace not only the science but the art of entrepreneurship. Entrepreneurship pedagogies should be seen as a means rather than an end in order to achieve student learning (Fayolle, 2013).

Most of the research that report of teaching methods, report some disagreements regarding what are the best pedagogies in EE. For instance, Benett (2006) in his study about business lecturers found that the educators had no agreements on how courses should be taught. Others, as Rae and Carswell (2001), have discussed that there is a distinction between the teachable and the non-teachable elements of entrepreneurship. The teachable of entrepreneurship represents the science of entrepreneurship, conversely, the non-teachable refers to the art of entrepreneurship.

Mwsalwiva (2010) through a literature review on EE, identified that the most important teaching or pedagogical methods are divide into two main groups: traditional and innovative methods. Figure 3 summarizes the most common pedagogies used in EE 
from the literature review classified between traditional or passive and innovative or active pedagogies.

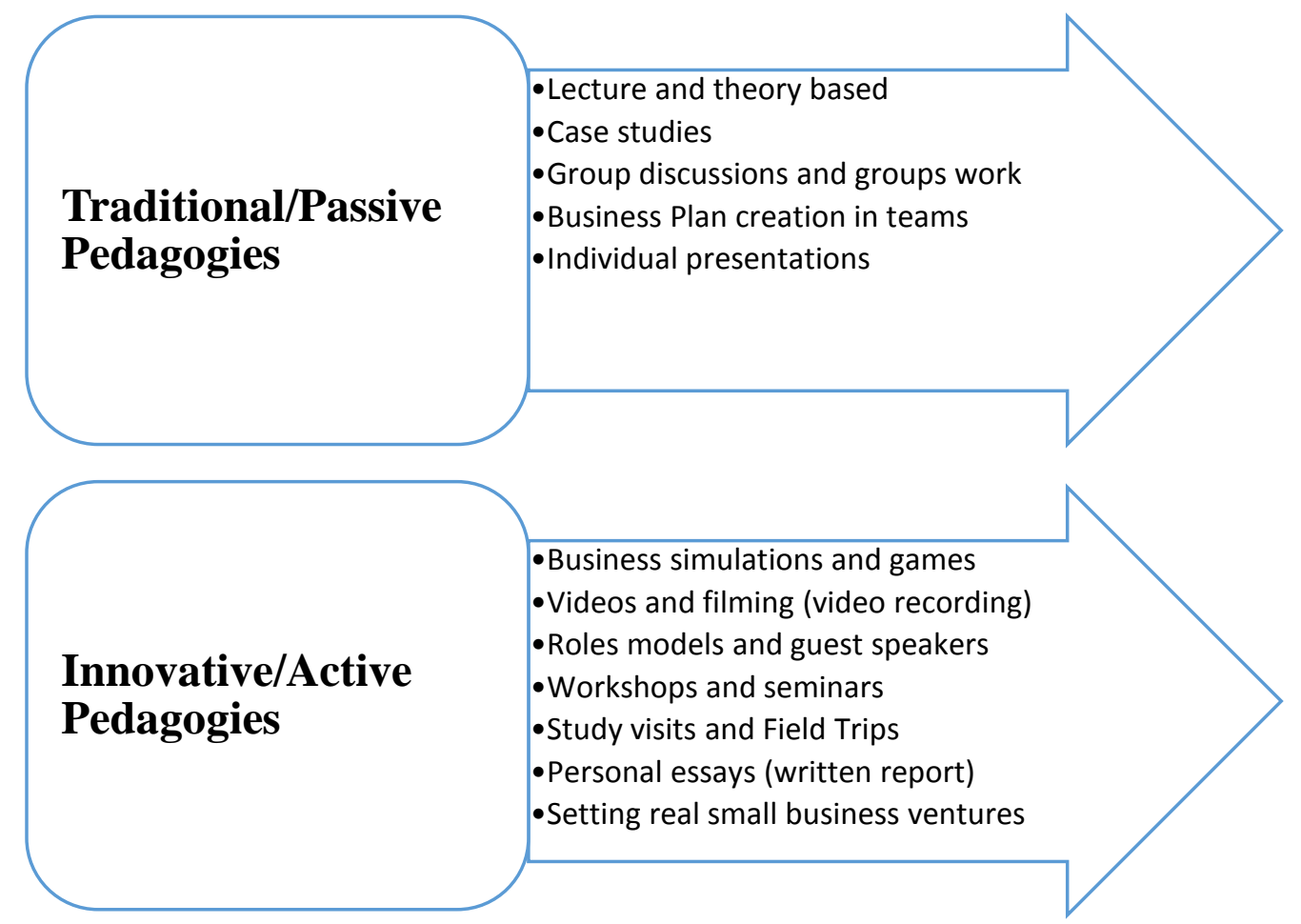

Figure 3. Traditional versus innovative pedagogies in EE. Adapted from Mwaslawiba (2010), Bennet (2006), Fiet (2001), Fayolle and Gailly (2008), and Hindle (2007).

The traditional or passive methods are actually common methods used in business education and are less effective in fostering entrepreneurial skills (Solomon et al., 1994). Active or innovative methods are those pedagogies more action-based or more experiential in terms of help students' learning (Gibb, 2002). In the following section, I expand the details about each type of pedagogies in EE. 


\section{Traditional/Passive Pedagogies in Entrepreneurship}

In traditional or passive teaching methods such as lecturing and seminars, students only receive the transmission of entrepreneurship knowledge through learning by reading and listening to the teacher instead of learning through the active participation in group activities (Gibb, 2002). The more typical entrepreneurship pedagogies primarily used are lectures, seminars, case studies, and business planning. The use of business plan creation is one of the dominant and traditional pedagogies applied in classrooms, followed by lectures and cases studies (Heinonen \& Poikkijoki, 2006). All of them are called conventional entrepreneurship pedagogies or passive methods because they do not effectively activate entrepreneurship learning and thinking (Mwasalwiba, 2010).

Conventional pedagogies such as those commonly used in business classroom are focused on transferring knowledge and facts about entrepreneurship instead of focusing on helping students to learn how to think entrepreneurially (Krueger, 2007). Some of these traditional entrepreneurship teaching approaches are process-oriented (Neck \& Greene, 2011) but not all of them help potential entrepreneurs take more responsibility for their learning and career life (Mwasalwiba, 2010). In fact, some research revealed that the best scenario for EE should be more than just looking at the process of creating enterprises represented in the type of learning for entrepreneurship. Teaching methods in EE might imply developing an entrepreneurial perspective, mindset, and skills which can be trained in every individual in the society (Kirby, 2004; Kuratko, 2005; Sarasvathy, 2008b). 
Traditional education methods such as lectures and seminars are mainly focused on transmitting facts and concepts. Some argue that they are inappropriate in making individuals become more entrepreneurial (Henry, Hill, \& Leitch, 2005; Mwasalwiba, 2010) because traditional pedagogies are insufficient to alter behaviors, skills, and the mindsets that students require in order to become entrepreneurial thinkers (Krueger, 2007; Taatila, 2010). Kirby (2004) claimed that the lecture and seminars are good to prepare students to work for an entrepreneur not to become one. Solomon, Duffy, and Tarabishy (2002) indicated that lectures are losing their appeal and power as pedagogies because they do not produce entrepreneurs. However, Mueller (2011) argued that some pedagogies such as simulation of business planning activities, role models, and feedback processes might increase the entrepreneurial intention.

EE has shown some improvements in terms of the use of more innovative type of pedagogies by using guest speakers in classes to expose role modeling to students (Heinonen \& Poikkijoki, 2006). However, this effort is still insufficient to influence entrepreneurial attributes (Mwasalwiba, 2010). One of the reasons is that traditional pedagogies such as lecturing avoiding recognizing learning as a process. Fiet (2001) asserted that entrepreneurship educators rely on traditional or more lecture-based methods because they can be easily accomplished, and also because they require less investment.

There is an agreement among EE research that there needs to be a shift of entrepreneurial pedagogies, moving away from accentuating traditional methods to integrating more innovative pedagogical techniques that enable students to practice 
entrepreneurial thinking through creativity, learning from failure, reflection, and resilience. (Greenberg et al., 2011; Kozlinska, 2012; Maritz \& Brown, 2013). In the next section, I explain different innovative pedagogies in entrepreneurship and the rationale why entrepreneurship teaching pedagogies should be a dynamic mix of tools of process and action to affect entrepreneurial intentions (Makimurto-Koivumaa \& Puhakka, 2013; Mueller, 2011; Neck \& Greene, 2011).

\section{Innovative/Active Pedagogies in Entrepreneurship}

Innovative pedagogies in entrepreneurship classrooms requires a learning environment that takes place in context and occurs through the active participation of the student. The educators has the role of facilitator and coach (Hannon, 2006). Simulation on business creation process is one of the most applied pedagogies because it can develop a learning environment that replicates some aspects of entrepreneurship (Pittaway \& Cope, 2007b). Developing and using new holistic and interactive entrepreneurship pedagogies might better help students become more entrepreneurial in their existing firms or in creating new businesses. Various examples of the use of non-conventional approaches and pedagogies for entrepreneurship appear in the literature. For instance, an entrepreneurial direct approach (Pittaway \& Cope, 2007a), and a holistic and effectualbased approach for entrepreneurship (Makimurto-Koivumaa \& Puhakka, 2013).

A recent view of entrepreneurial teaching methods illustrates the complexity and incongruence of EE, with various methods fulfilling various objectives, with a poor demarcation between the types of learning goals in EEP (Msasalwiba, 2010). However, using more active pedagogies, students are capable of engaging in the development of 
their own business proposition, which involves trial and error, experimentation and problem solving (Pittaway \& Cope, 2007a; Politis, 2005).

Over the past decade an increasing number of researchers have recommended the use of pedagogies based on action, self-analysis and reflexivity in EE (Fayolle \& Toutain, 2013). However, more research is needed in terms of addressing relationships between the type of teaching approach and learning outcomes (Fayolle, 2013). Current research suggest that entrepreneurship pedagogies should go beyond knowing how to write a business plan (Perry et al., 2011). Pedagogies in EE need to help students develop entrepreneurial thinking. Hence, universities and entrepreneurship educators need to change their understanding of EE using emerging theories of entrepreneurship (Fisher, 2012). Effectuation considers entrepreneurship as a method of action and thinking rather than just a business creation process (Sarasvathy \& Venkataraman, 2011). Thus, under these emerging perspectives, action-based methods through a portfolio of pedagogies seems to work better (Perry et al., 2011).

Using multiple tools to help students learn through entrepreneurship, by using learning-by-doing pedagogies (Gibb, 2002; Neck \& Greene, 2011), experiential learning activities (Kolb, 1984) such as business simulations, games and competitions, reflective practice (Schön, 1983, 1987), and effectual theory (Greenberg et al., 2011; Sarasvathy, 2008b). These pedagogies offer a more effective alternative to lectures and seminars (Mwasalwiba, 2010). Unfortunately, those pedagogies have barely been adopted in entrepreneurship classrooms because it is difficult to teach and necessitates adequate training and investing time and effort from the instructors (Bennett, 2005). 
Effectuation theory as pedagogy could be key to EE because has begun to question the universal applicability of the causation-based (traditional) model of entrepreneurship, but more empirical research is needed (Perry et al., 2011). One of the few articles that refers to effectuation as a pedagogy for entrepreneurship, suggests that in order to teach entrepreneurship, a combination of different pedagogical methods is needed. In other words, using an effectuation-based framework and emergent pedagogies, students could be trained for uncertainty. The effectuation-based framework for teaching entrepreneurship needs to be further developed but it could be built on action-based learning methods such as learning experiences close to real context, experiential learning environments, and an entrepreneurial mindset (Makimurto-Koivumaa \& Puhakka, 2013; Pittaway \& Cope, 2007). Hence, looking at the future of EE as a dynamic and evolving discipline, teaching potential entrepreneurs requires transferring entrepreneurial skills to students using innovative and unconventional teaching approaches based on action and practice (Neck \& Greene, 2011).

In sum, EE at university level commonly uses lectures, literature reviews, seminars, and examinations as traditional pedagogies which are mainly theory based and emphasize successful cases of entrepreneurs in business. They represent a passive model of education because teachers use them to transmit information about entrepreneurial features and to acquire new knowledge about entrepreneurship theory. Entrepreneurship facts and content are necessaries in EE and can be easily taught (Haase \& Lautenschläger, 2011), but should not be the primary focus. Current worldwide research agrees that now more than ever we need innovative solutions, new approaches, and new ways of 
operating to identify, create, and pursue opportunities made by entrepreneurial individuals (Makimurto-Koivumaa \& Puhakka, 2013).

\section{Review of Methodological Literature in EE}

Molina-Azorin et al. (2012) and Wang and Chugh (2014) in their revision of the literature about EE suggest that the use of mixed methods may help researchers to move entrepreneurship research forward because it might help researchers mitigate the limitations of using just quantitative or qualitative methods in single studies (Fayolle, 2013). From the literature review, I could observed that the majority of research use quantitative research methods. Indeed, some current empirical studies about entrepreneurial intentions revealed a significant but a small correlation between $\mathrm{EE}$ and students' entrepreneurial intentions (Bae et al., 2014; Fayolle \& Gailly, 2013). However, these articles suggest that future research in $\mathrm{EE}$ and entrepreneurial intentions should use MMR design to explain the associations between EEP and participants' entrepreneurial intentions that this research study attempted to explore.

\section{Summary}

In sum, the field of EE is young and fragmented and currently is facing the phase of looking for more legitimacy (Winkel, 2013). There is a gap between what educators teach in entrepreneurship courses and what entrepreneurs really do when they act entrepreneurially (Fayolle, 2013). There is no doubt that it is challenge for entrepreneurship educators. According to Fayolle and Gailly (2008) one of the suggestion 
to improve entrepreneurship teaching is clarifying the philosophical positions about EE and the teaching methods used by entrepreneurship educators.

In this chapter, I presented literature review on EE that helped me to develop the argument that support my research study. Specifically, I argue that educators in the teaching field of entrepreneurship need a clear understanding of the educational variables of the EEP such perspectives about teaching, teaching methods or pedagogic and student learning. Entrepreneurship educators should identify and understand what type of learning goals they want for their students to find alignment with the pedagogical methods that seems to be more effective for each type of learning (Maritz \& Brown, 2013). Due to the variety of teaching methods applied in EEP, finding alignment among these educational variables of EEP such as teaching methods, educator teaching beliefs, and student learning outcomes seems essential to evaluate the impact that those variables might have on participants' entrepreneurial intentions (Fayolle \& Gailly, 2013; Fayolle \& Liñán, 2013; Mwasalwiba, 2010).

In the next chapter, I present the methodology used in this research developing a rationale of using a MMR in conducting this study. 


\section{CHAPTER 3}

\section{METHOLODOGY}

\section{Introduction}

In this chapter, I explain the methodology used in this research, articulating the purpose of the study and the research questions. In particular, in this chapter I first describes the mixed method research methodology, participants, sampling methods and procedures. Second, I move on to explaining the procedures for data collection and analysis in both chronological Phases of this study (quan $\rightarrow$ QUAL). Third, this chapter continues with the role of the researcher, and strategies used for validating the findings and minimizing researcher bias. Last, I present a brief summary of chapter 3 content.

\section{Purpose of the Study and Research Questions}

The purpose of this study was twofold: first to explore relationships between faculty teaching perspectives and the experience of the faculty and student entrepreneurial intentions in required entrepreneurship courses at Chilean universities. From this information, I identified those faculty who seem to have increased impact on students' entrepreneurial intentions (Phase I: quantitative, secondary data), and second to describe and explain how entrepreneurship faculty define and think about EE and teaching methods (Phase II: qualitative, primary data). 
The research questions (RQ) for this study were:

RQ1: How do the perspectives (beliefs) about teaching as measured by the TPI and the entrepreneurial experience by faculty in entrepreneurship courses relate to the entrepreneurial intentions level of students in their classes? (quan)

RQ2. How do identified entrepreneurship faculty describe EE? (QUAL)

RQ3. How do identified entrepreneurship faculty describe the relationship between entrepreneurship teaching and entrepreneurial learning? (QUAL)

RQ4. How do identified entrepreneurship faculty describe and explain the selection and the use of pedagogical methods? (QUAL)

RQ5. In what ways do faculty understandings of entrepreneurship teaching and pedagogies (QUAL) help to explain the relationship between faculty perspectives about teaching, the pedagogies they use, and student entrepreneurial intention (quan)?

\section{MMR}

I used MMR methods for this study. The popularity of MMR is expanding in social science beyond education and sociology toward others disciplines such as political science, comparative methods, and EE and research (Feilzer, 2010; Harrits, 2011; Molina-Azorin et al., 2012). A MMR is the class of research where the researcher integrates quantitative and qualitative research techniques, methods, concepts, and languages into a single study (Morgan, 2013). The MMR is the most commonly associated with pragmatic approach to research (Biesta as cited in Mertens, 2012, Feilzer, 2010; Creswell, 2014b; Johnson \& Onwuegbuzie, 2004; Morgan, 2007). Based on the work of Dewey, the pragmatic philosophy is guided by the assumption that research 
inquiry should be a form of experience that helps resolve uncertainty. From a pragmatic point of view, this process of inquiry is an "explicit attempt to produce new knowledge by taking actions and experiencing the results of that action" (Morgan, 2013, p. 6). Consequently, this study has been guided by the pragmatic paradigm because it is open to multiple methods, different assumptions, and methodological stances (Morgan, 2007). This study used quantitative methods in Phase I such as $t$ test and ANOVA statistical analysis as well as qualitative methods in Phase II such as the manual coding of interview transcripts through the step by step of thematic network analysis (Creswell, 2014a, $2014 b)$.

A MMR design is often the most appropriate for researchers who have a pragmatic philosophy (Morgan, 2013). The researcher combines or integrates quantitative and qualitative data collection and analysis in a single study (Johnson \& Onwuegbuzie, 2004). In the context of this research study, I used both quantitative and qualitative data, collected and analyzed sequentially, in order to answer the research questions following a paradigmatic philosophy of research. In contrast to philosophies that seek to emphasize the nature of reality, pragmatism emphasizes the nature of experience. Therefore, the pragmatic research approach is best suited for my research because it is pluralistic, problem- and practice-centered. My research suggests that there is not a single set of methods that are appropriate for understanding EE (Morgan, 2013) and quantitative and qualitative methods are compatible (Molina-Azorin et al., 2012).

In the context of this research study on EE in Chilean universities, the use of mixed method design may help to improve current entrepreneurship research by giving us 
access to different kinds of data and helping entrepreneurship researchers mitigate the limitations of using just quantitative or qualitative methods alone (Feilzer, 2010; MolinaAzorin et al., 2012). The integration of both kinds of data allowed me to capture a better picture of the current situation of teaching EE in Chilean universities. Particularly, having a quantitative database of entrepreneurship college student-faculty and adding qualitative research data in the form of interviews with entrepreneurship faculty helped me to understand how faculty make meaning about EE and teaching methods.

\section{Explanatory Sequential Mixed Method Research Design}

For this study, I used a particular kind of mixed method research: an explanatory sequential MMR design (Ivankova, Creswell \& Stick, 2006; Morgan, 2013). According to Stentz, Plano Clark, and Matkin (2012), the explanatory sequential design consists of two distinct Phases: quantitative (quan) followed by qualitative (QUAL). The rationale for the explanatory research design is that the quantitative data and their subsequent analyses (Phase I) provide a general understanding of the research problem. The qualitative data and their analysis (Phase II) explain those statistical results by exploring participants' views in more depth (Creswell, 2014b; Ivankova et al., 2006).

The explanatory sequential research design is represented using the notation quan $\rightarrow$ QUAL (as proposed by Morse in 1991 as cited by Morgan in 2013). Considers the quantitative data, Phase I, as the preliminary input for collecting and interpreting the qualitative data in Phase II (see Figure 4). One of the advantages of using this research design includes the exploration of quantitative results in more detail leading to a better understanding of the research problem. 


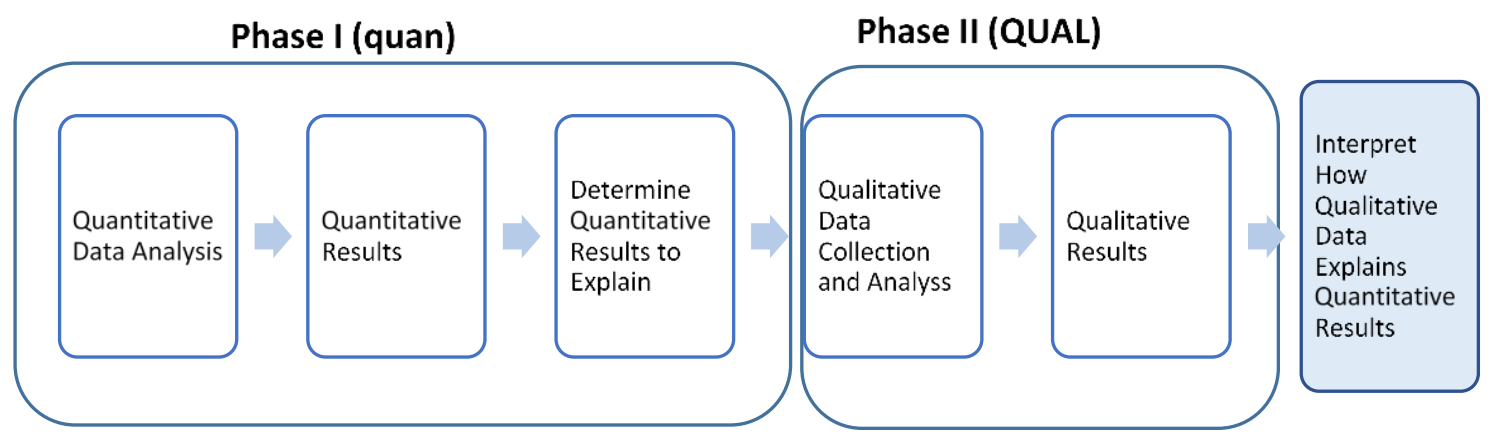

Figure 4. Explanatory sequential design in MMR (quan $\rightarrow$ QUAL). Adapted from Morgan (2013) and Creswell (2014a).

Phase I (quan). The goal of this quantitative Phase I was to identify entrepreneurship faculty who have an impact on student entrepreneurial intention. Secondary data were used in the Phase I of my study. This secondary data came from Albornoz's (2014) study of the effect that a required entrepreneurship course had on college students' entrepreneurial intentions in Chile (Albornoz, 2014). That study collected data on faculty that was not analyzed. These databases contained results from surveys on EE from more than 2,000 college students and 48 entrepreneurship faculty from different universities in Chile. Using Albornoz's data, I sought to assess through statistical analysis the relationships between two set of variables derived from the students and faculty surveys:

1. Faculty teaching perspectives from their TPI and student entrepreneurial intentions.

2. Faculty entrepreneurial experience and student entrepreneurial intentions. 
Then, using both datasets (student and faculty's surveys), I created a new database paired valid data of students with the faculty who taught the entrepreneurship class. The new database considers a subsample of valid student-faculty data $(n=270)$ about the differences between student entrepreneurial intention before and after taking the entrepreneurship class as well as faculty data about their teaching perspectives inventory, entrepreneurship experience and pedagogical methods used in their classes. Also, this quantitative results from Phase I guided the purposive sampling to conduct the faculty interviews in Phase II. A purposive sampling is most often used in qualitative research and for evaluation (Krathwohl, 2009). Also, purposive sampling was the most appropriate sampling strategy in this case, because it is based on the assumption that as a researcher I want to understand and gain insight from a subsample selected from the quantitative data to explore further (Merriam, 2009). In sum, this quantitative database allowed me to respond research question 1 and to select a subsample of faculty to conduct a follow-up interviews in Phase II of this study.

Phase II (QUAL). This qualitative Phase II drew upon the subsample of data ( $n=270 ; 18$ faculty data per 15 student data each). The goal of this Phase II was to conduct semi-structured interviews from those faculty who were in the new data set ( $n=18)$. During this QUAL Phase II, I conducted eight individual in-depth interviews with entrepreneurship faculty using the same protocol (see Appendix F and G) to obtain their specific views and hear their voices in more detail about the phenomenon of teaching entrepreneurship in university courses in Chile. (Creswell, 2014a, 2014b; Creswell \& Plano Clark, 2011). 


\section{Research Setting}

This study took place in Chile's higher education system. Chile currently has 59 public, traditional-private and private universities that serve more than 1 million (Consejo Nacional de Educacion, 2015) students and employ approximately 67,000 university instructors and professors (Sistema de Investigación Educación Superior Chile, 2015). The quantitative data set used in this study contains more than 2000 surveys from entrepreneurship college students from a pre and posttest that explored the effect that a mandatory entrepreneurship class have on their intention to become an entrepreneur. To do that, I used as a framework the TPB (Azjen, 1991) that according to research is the most well-known theory to assess EE and training as mentioned in the literature review presented in chapter 2. Also this data set contained valid responses from an online survey from 48 faculty who taught entrepreneurship courses regarding entrepreneurship teaching beliefs though their TPI, entrepreneurship experience and teaching methods. Both data sets (college students' survey results and faculty's survey results) served as preliminary input to create a new database combining student-faculty that finally contained a sample of 270 college students and 18 entrepreneurship faculty from nine different universities located in different regions in Chile.

\section{Procedures}

Table 4 shows a summary of the procedures of this explanatory sequential research study and it helps visualize the sequence of the data collection, analysis and its time line, showing the priority of qualitative data analysis, and the connecting points of the two methods. 
Table 4

Explanatory Sequential MMR Procedures (quan $\rightarrow Q U A L$ )

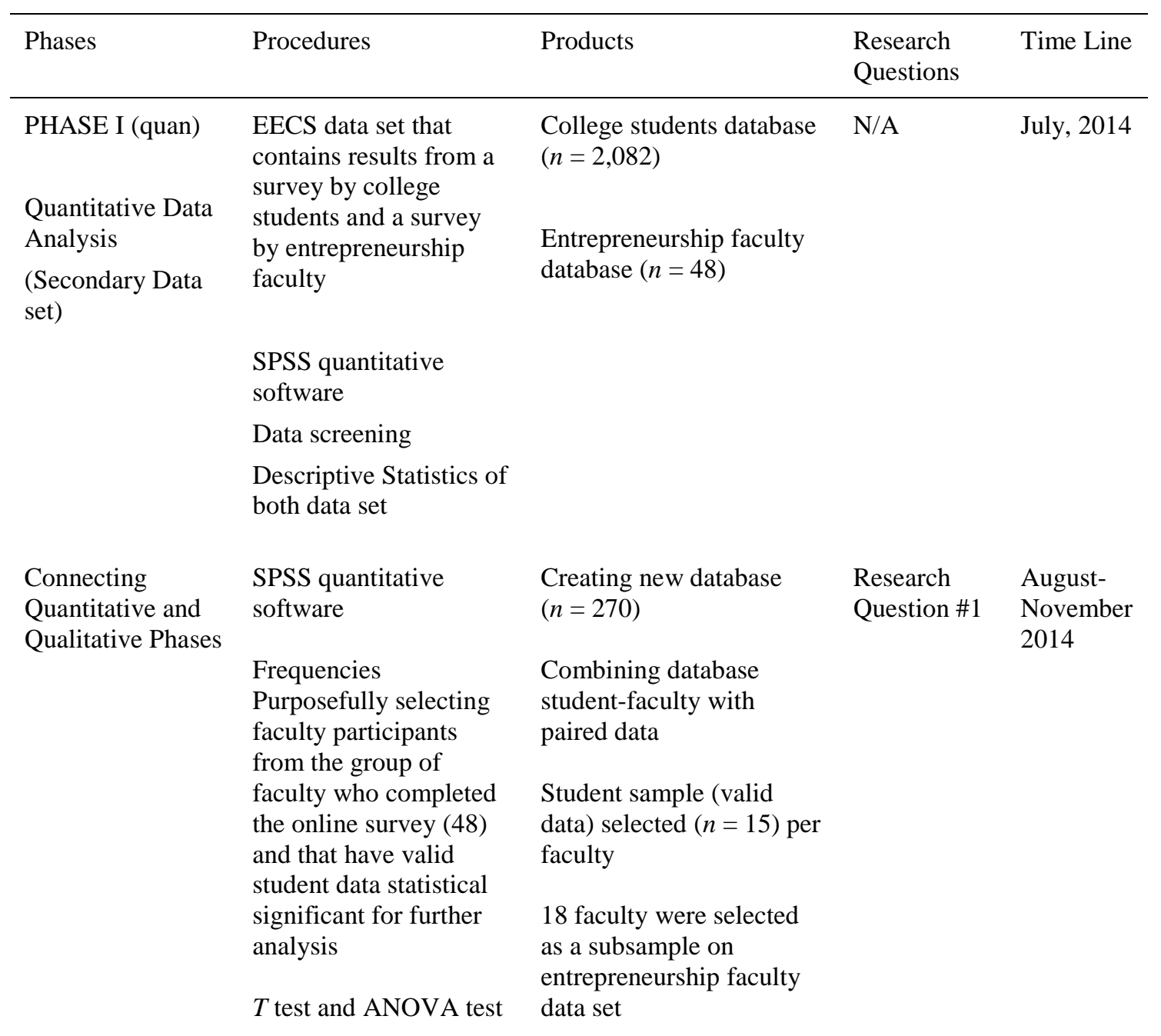


Table 4 (continued)

\begin{tabular}{|c|c|c|c|c|}
\hline Phases & Procedures & Products & $\begin{array}{l}\text { Research } \\
\text { Questions }\end{array}$ & Time Line \\
\hline \multirow[t]{5}{*}{$\begin{array}{l}\text { PHASE II } \\
\text { (QUAL) } \\
\text { Qualitative Data } \\
\text { Collection }\end{array}$} & $\begin{array}{l}\text { Email invitation to } \\
\text { participate in the } \\
\text { interview to all of the } \\
18 \text { faculty from the new } \\
\text { database student-faculty }\end{array}$ & $\begin{array}{l}\text { Interview Protocol } \\
\text { Cases }(n=8 \text { faculty) } \\
44 \% \text { response rate }(8 / 18)\end{array}$ & & \multirow[t]{5}{*}{$\begin{array}{l}\text { December } \\
\text { 2014- } \\
\text { March } \\
2015\end{array}$} \\
\hline & $\begin{array}{l}\text { Informed consent } \\
\text { signed by faculty } \\
(n=8)\end{array}$ & $\begin{array}{l}\text { Text data } \\
\text { Audio recording }\end{array}$ & & \\
\hline & $\begin{array}{l}\text { Individual in-depth } \\
\text { interview (semi- } \\
\text { structured) with faculty } \\
\text { participants }\end{array}$ & $\begin{array}{l}\text { Interview transcripts } \\
\text { Artifact description }\end{array}$ & & \\
\hline & $\begin{array}{l}\text { Collection of syllabus } \\
\text { of each } \\
\text { entrepreneurship course } \\
\text { taught by faculty as } \\
\text { artifact }\end{array}$ & & & \\
\hline & $\begin{array}{l}\text { Email follow up } \\
\text { interviews }\end{array}$ & & & \\
\hline $\begin{array}{l}\text { PHASE II } \\
\text { (QUAL) }\end{array}$ & Reading all transcripts & $\begin{array}{l}\text { Codes and Themes Basic, } \\
\text { organizing, and global } \\
\text { themes }\end{array}$ & \multirow{2}{*}{$\begin{array}{l}\text { Research } \\
\text { Question \#2 } \\
\text { to \#4 }\end{array}$} & \multirow[t]{2}{*}{$\begin{array}{l}\text { February- } \\
\text { May } 2015\end{array}$} \\
\hline $\begin{array}{l}\text { Qualitative Data } \\
\text { Analysis }\end{array}$ & $\begin{array}{l}\text { Manual coding } \\
\text { Coding using thematic } \\
\text { network analysis }\end{array}$ & $\begin{array}{l}\text { Similar and different } \\
\text { themes and categories }\end{array}$ & & \\
\hline $\begin{array}{l}\text { Integration of the } \\
\text { Quantitative and } \\
\text { Qualitative } \\
\text { Results } \\
\text { (quan } \rightarrow \text { QUAL) }\end{array}$ & $\begin{array}{l}\text { Interpretation and } \\
\text { explanation of the } \\
\text { quantitative and } \\
\text { qualitative results }\end{array}$ & $\begin{array}{l}\text { Discussion, Implications } \\
\text { Future Research }\end{array}$ & $\begin{array}{l}\text { Research } \\
\text { Question \#5 }\end{array}$ & $\begin{array}{l}\text { April- } \\
\text { June } 2015\end{array}$ \\
\hline
\end{tabular}




\section{Data Sources}

Being an explanatory sequential mixed method study (quan $\rightarrow$ QUAL), my research took part in two consecutive Phases. In Phase I (quan), two data sets were analyzed to combine student-faculty data in order create a new database $(n=270)$ associating student-faculty data as well as to respond to research question 1. In Phase II (QUAL), I conducted eight interviews with entrepreneurship faculty and analyzed syllabi from their entrepreneurship courses. All the qualitative information helped me to respond research questions 2 to 5 .

\section{Phase I (quan)}

College students' database. This secondary database $(n=2,047)$ was formed by the responses from an online survey about entrepreneurial intention by college students in Chile during 2012-2013 academic year (Albornoz, 2014). The college students' survey contained 28 questions (see Appendix B) adapted from the literature review of models of entrepreneurial intentions (Albornoz, 2012). The online survey included four validated scales based on the TPB (Azjen, 1992): (a) Entrepreneurial intentions, (b) Attitude toward business ownership, (c) Perceived behavioral control or self-efficacy, and (d) Subjective norm. These are students' variables to be used in the data analysis. Specifically, a total of 2083 college students corresponding to 10 universities from 13 different regions in Chile responded the online survey (Albornoz, 2014). The college students database after paired data contains 2047 valid cases from the pretest during the first entrepreneurship class and posttest during the last class or after they completed the course. 
Entrepreneurship faculty database. This secondary data source $(n=48)$ came from an online survey of entrepreneurship faculty (see Appendix D and E). This online survey included 31 closed- and open-ended questions that collected faculty's information about perspectives of teaching in entrepreneurship courses based on the TPI, pedagogical methods used in classrooms, their entrepreneurial experience, and demographic information. This online survey was sent to the group of entrepreneurship faculty who were teaching the entrepreneurship courses during 2013-2014 academic year. Finally, this data set contains 48 valid data from entrepreneurship faculty who were teaching entrepreneurship courses at Chilean universities.

\section{Data Collected}

\section{Phase II (QUAL)}

Participants. Criteria for selecting the faculty participants for the interview during the qualitative Phase II included: (a) have taught required undergraduate entrepreneurship, (b) must have done the online survey and (c) being part of the subsample that combined student-faculty data $(n=270)$. According to Plano-Clark and Creswell (2010), purposive sampling is when researchers intentionally select individuals to learn about or understand the central phenomenon, in this case EE in Chilean universities. In this research, I used a purposive sampling to select participants to interview. A total of 18 out of 48 entrepreneurship faculty met those criteria mentioned above. Thus, I personally sent an email to all of entrepreneurship faculty of the new database student-faculty to invite them to participate in the semi-structured interview. Eight out of 18 entrepreneurship faculty (44\% response rate) responded the invitation and 
signed the informed consent, demonstrating their willingness to participate in the individual interview.

Therefore, I conducted eight individual interviews, this small sample size also followed the idea of saturation (Creswell, 2014b), that means that the researcher stopped collecting data when the categories (or themes) are saturated. In other words, when qualitative data collected no longer reveals new properties. It is worth noting that a limitation of purposive sampling is that the participants are not randomly sampled from the population of 18 faculty. Thus, they may not be representative of a larger group to form generalization of the results and findings, but it will be useful for transferability of the process conducting this research. However, purposive sampling is commonly used in educational research and is valuable when a researcher seeks participants with specific characteristics.

Interview guide for entrepreneurship faculty. I used a semi-structured interview protocol (see Table 5) to each entrepreneurship faculty. In this study, the semistructured interview guide contained a mix of nine questions about faculty’s understanding of EE, entrepreneurship teaching and how they select and use pedagogies and teaching methods in their classrooms. Two types of questions were used: main questions and probes to follow-up, clarify, and gain depth to faculty responses (Merriam, 2009). I also used probing questions to add detail to original answers or to allow faculty to elaborate on what has already been said. In sum, the semi-structured interviews helped to standardize data and facilitate the focus on the topic of inquiry, in this case EE, teaching and learning. For this study, this interview structure allowed me to have a depth 
conversation about the same topic with each of the entrepreneurship faculty participant in the sample. This semi-structured individual interviews were conducted with eight $(n=8)$ entrepreneurship faculty.

Table 5

Interview Protocol Entrepreneurship Faculty

Q1: Tell me about your experience in teaching entrepreneurship Probes: What made you interested in teaching entrepreneurship, in general? How did you start teaching in this area? What you value most about teaching entrepreneurship?

Q2: How do you define EE? Probes if not mentioned or very little discussion and time allows: How do you describe educating students to act entrepreneurially? Some people say that "entrepreneurship cannot be taught." What do you think? How do you define entrepreneurship as a learning phenomenon?

Q3: What are the specific pedagogies that you are currently used in your classes?

Probes if not mentioned or very little discussion and time allows: Tell me more about some good experiences and examples in teaching entrepreneurship. Tell me more about balancing workload outside classroom practice. Tell me more about dealing with time to use or not different pedagogies

Q4: What influenced you to select the pedagogies that you are using in your classes now? Probes: What else? Who has something different? Can you give me example of why you select those?

Q5: What do you like the most about the pedagogies from your current syllabus/current class? Probes if not mentioned or very little discussion and time allows: Are self-selected or are suggested by the university? Why do you like those pedagogies? What do you think about training on pedagogies and teaching methods in general?

Q6: Tell me more about the experience of implementation those pedagogies with students? Probes Students' reaction (positive/negatives/challenges). What are pedagogies that you think do not work with university students, why? What do you suggest to overcome difficulties? What do you suggest to improve the current teaching practices?

Q7: What are the factors that prevent you from implementing new/different pedagogies? Probes if not mentioned or very little discussion and time allows. What do you think there are the main factors? (Personal or organizational)

Q8: Name and describe briefly 2-3 pedagogical methods that you want to apply in the future: Probes if not mentioned or very little discussion and time allows: Why or from whom you are inspired to implement those?

Q9: Imagine a positive future: What do you visualize will be a good class, given by you as entrepreneurship educator/faculty?

Probes: Ask them to name at least 2 characteristics of a good or effective entrepreneurship class. What do you need now to become that kind of teacher in EE in the future? Anything else that you want to add to this interview? 
Each interview took approximately between 60-80 minutes and took place mostly at the participant's university office or another place suggested by the interviewee. Participant were contacted by email or phone call. After they signed the informed consent, we set up a mutually convenient time and location for the face-to-face interview in Chile. Interviews were conducted in Spanish and they were transcribed. It is worth noting that the researcher is a native Spanish speaker. The interviews were recorded with two digital voice-recorder for backup and I took notes during the interviews.

Entrepreneurship course syllabi (Artifacts). A total of six (6) different syllabi from the entrepreneurship courses taught by faculty interviewed were collected as another source of data during or after the interview. A syllabus is a written document designed to provide guidance to students in the course and it contains the objectives and learning goals for the class (Fink, 2003). Each syllabus collected was read in order to find evidence of the content, learning goals and pedagogical practices of each entrepreneurship course as well as to contrast the information provided by the faculty during the interview about entrepreneurial learning goals. A structural coding method based on Saldana (2009) was used to translate the written narrative information from the syllabus into codes. According to the author, the structural coding applies conceptual phrases representing a topic of inquiry that relates to a specific question. In this case, what type of pedagogies and learning goals each faculty has on their entrepreneurship classes? (Research question \#4) Moreover, as a frame to explore the different forms of EE and the types of learning goals that the course intend to develop, I used the typology of EE (see Figure 5) based on the work of Pittaway and Edwards (2012) because its 
explain in detail what it means learning about, for and through EE and also it is related with the literature reviewed in this study presented in chapter 2 .

Data management. All the data sources collected in both Phases of this research (quan $\rightarrow$ QUAL) such as all transcriptions, original tapes, documents, artifacts, computer database, and notes have been maintained in a locked file cabinet in the researcher's home office. Access to materials will be available only to the researcher. All files will be maintained for the time period that the Portland State's Institutional Review Board (IRB) committee defined after the completion of this research study.

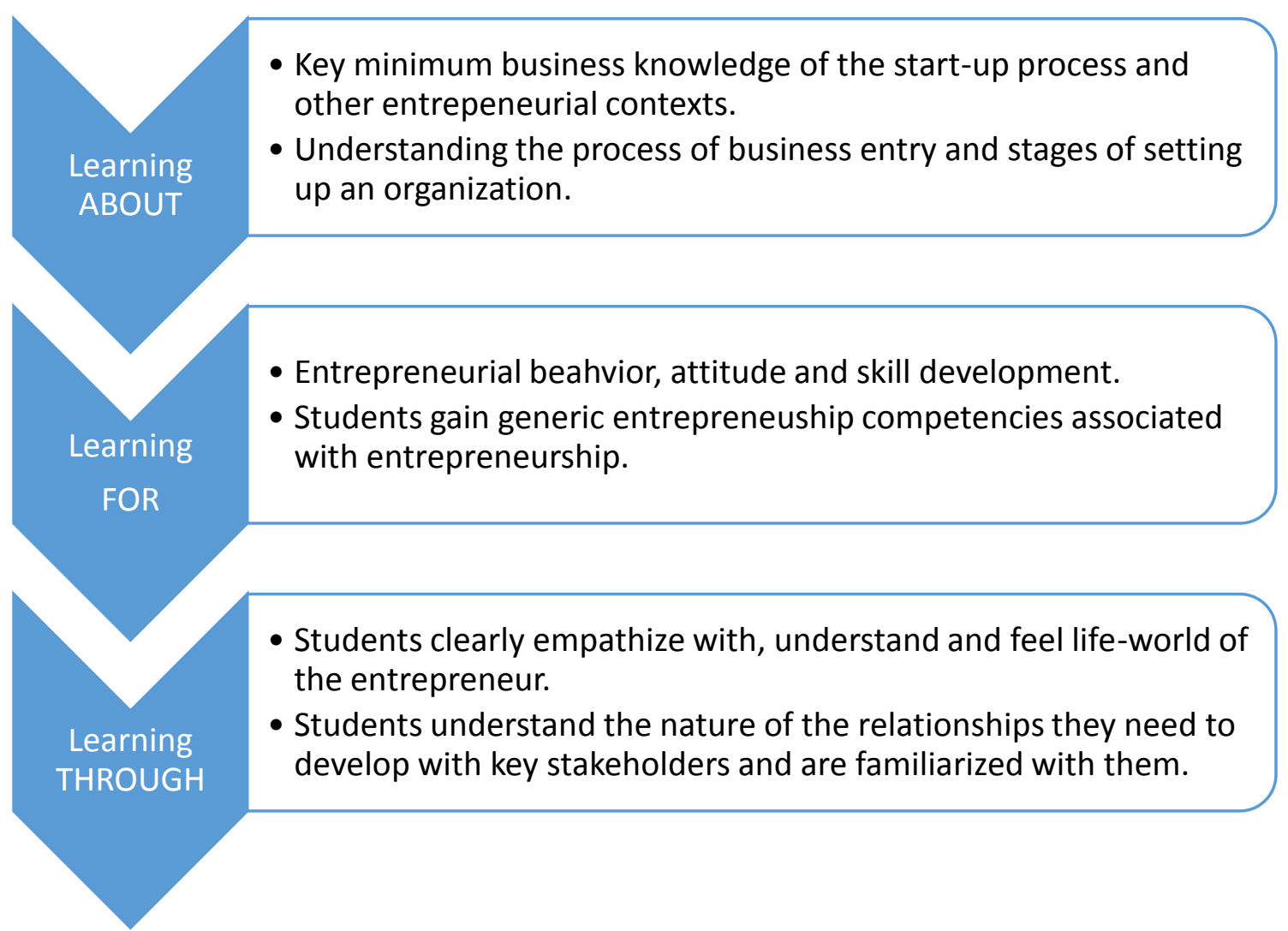

Figure 5. EE forms and learning objectives. Adapted from Pittaway and Edward (2012) to conduct structural coding of the syllabi. 


\section{Data Analysis}

Considering that this study used an explanatory sequential research design (quan $\rightarrow$ QUAL) in two chronological Phases, I statistically analyzed the quantitative data from Phase I, as the preliminary input to analyze qualitative data and to select participants for the interview in Phase II.

\section{Phase I (quan)}

This quantitative Phase I of the study aims to answer the research question \#1 about How do the perspectives about teaching (TPI), the entrepreneurial experience and the type of pedagogical methods used by faculty in their classroom relate to the students' entrepreneurial intention level? I used the Statistical Package for the Social Sciences (SPSS) software for data screening, analysis and testing college student and faculty database. I used the $t$ test for a dependent sample or paired sample to compare the differences between the entrepreneurial intention before and after the mandatory entrepreneurship class. According to Creswell (2014b), the statistical $t$ test yields a comparison of two groups on terms of outcomes and before a $t$ test is run, it is important to check the assumptions of normality and homogeneity of variance (Field, 2009).

Subsample of combined student-faculty data. The new database was the result of a combination between college student database $(n=2,047)$ and entrepreneurship faculty database $(n=48)$ as a whole sample. The new database student-faculty contains a subsample $(n=270)$ of valid student data of their entrepreneurial intention before and after taking a mandatory entrepreneurship class. I combined both databases in order to have valid data from students per faculty. The arguments behind this combination to 
paired valid responses from the online survey from students (pretest and posttest on entrepreneurial intention) with data to each faculty who taught the specific entrepreneurship course. This step allows me to homogenize the variance of the new database with 15 valid student data from pre and posttest and per faculty.

The assumption behind this analysis was to compare group means (students per faculty) and to demonstrate that the variance is homogenized. Also, in order to minimize the statistical error of the sample, I used a simple sample $t$ test as a criteria to select a group of students per faculty. This statistical test showed that a number of 15 students per faculty is the significant number to create a new and combined database $(n=270)$. The following are the quantitative variables based on the students responses from the online survey (see Appendix B and C):

(1) Entrepreneurial intention scale. The entrepreneurial intention contains items that aim to capture the intention of an individual to start a business. Participants were asked to specify for each statement whether they agree or disagree with the statement (question \#12 in college students' survey). The data used in this analysis is the mean of the difference between pre and posttest. In the case of the students' entrepreneurial intentions based on the TPB (Azjen, 1991), I provide observations and measures at the pre and posttest to calculate the change/variation. The student's entrepreneurial intention data were calculated using the difference between the scores of the pre and posttest. I provide statistic for the variables used such as the means and standard deviations of the other variables measured within Azjen's (1991) model of entrepreneurial intentions, attitudes, perceived behavioral control, and subjective norms. 
(1.1) Attitude toward business ownership scale. This scale includes six reasons in favor of self-employment in a 5-point Likert scale (question \#16 in college students' survey).

(1.2) Perceived behavioral control scale or self-efficacy. This item asks about the perceived ability to success as business owner. Participants were asked to rate themselves from 0 to 100 for each statement (question \#13 in college students' survey).

(1.3) Subjective norm scale. This variable aims to explore the social approval and support that the person would receive in deciding to become an entrepreneur (questions \#14 and \#15 in college students' survey).

The following are the quantitative variables from the entrepreneurship faculty data set.

(2) Entrepreneurial experience. This online survey also asked faculty about their entrepreneurial experience (questions \#8 and \#10). Participants were asked to answer yes or no to the question: Have you had owned or currently own a business?

(3) TPI (Teaching perspective inventory). The TPI is a 45 -item instrument that assesses the orientation to teaching. The items (questions \#2,\#3 \#4 in faculty's survey) are statements constructed using a 5-point Likert-scale about educational beliefs, intentions and actions (Pratt, 1998). Responses identify dominant views of teaching from the five different perspectives on teaching that include: transmission, apprenticeship, developmental, nurturing, and social reform. The perspective that scores the highest, becomes the dominant perspective of teaching for the faculty. To relate this variable to the entrepreneurial intention of the students, I used an ANOVA test. Fields (2009) 
defines the analyses of variance (ANOVA) as a statistical model used to analyze situations in which we want to compare more than two conditions or groups of people. In fact, an ANOVA test tells us whether three or more means are the same through testing the null hypothesis that all group means are equal. In addition, an ANOVA test makes three important assumptions: that the variances in each condition need to be similar, that the observations should be independent and, that the distributions within groups are normally distributed. In this case, the independent variable is the type of teaching perspective profile because we have five different categories in which each faculty has an emphasis: Transmission, Apprenticeship, Developmental, Nurturing, and Social Reform. The dependent variable or outcome is the difference between pre and posttest on students' entrepreneurial intention. This data provides numeric information about teaching perspective that will be related to the students' entrepreneurial intention.

All these numeric data provided the information to answer the research question 1 and once these databases were analyzed, partial results were used to identify a subset of entrepreneurship faculty $(n=18)$ to take part in a semi-structured interview using a purposive sampling.

\section{Phase II (QUAL)}

The goal of this Phase II was to conduct semi-structured interviews from those faculty who were in the subsample $(n=270)$. A total of 18 faculty from the total of 48 that responded the online survey met the criteria to participate in the study. As I mentioned in chapter 3 , I personally sent an email invitation to all of the 18 faculty to participate in the interview. I used purposive sampling to select participants as well as the 
results of the quantitative Phase described in the previous section. Eight faculty responded to the invitation and agreed to participate. In terms of increasing validity of the data collection, I used the same interview guide or protocol in conducting the semistructured interviews. All interviews were conducted in Spanish and they were transcribed. The main goal of the interview was to hear from faculty their understanding of EE, entrepreneurship teaching and how they select and use pedagogies and teaching methods in their classrooms. In this section, I present an overview of the eight participants interviewed and I describe the process of analyses of the interviews questions using thematic network (Attride-Stirling, 2001).

Overview of interviewed participants. The eight entrepreneurship faculty interviewed worked for six different Chilean universities and in three different geographical regions. From these universities, three are traditional or public universities and three are private universities. All of these universities are accredited by the National Accreditation Commission (CNA in Spanish).They have different accreditation's years which means that they have differences in the quality of the education that they are offering to students according to the standards of the CNA.

Table 6 shows an overview of the entrepreneurship faculty participants that contains demographic information such as gender and years of experience collected during the interview. From the eight participants, four faculty are female. Age range is from midtwenties to mid-forties and they have 4.75 years of experience teaching entrepreneurship in universities on average. Male faculty's age range are from mid-twenties to early- 
seventies. They have an average of 7.5 years of experience teaching entrepreneurship in universities.

Table 6

Overview of Eight Participants Interviewed

\begin{tabular}{|c|c|c|c|c|c|c|c|}
\hline \# & Name $(*)$ & Gender & $\begin{array}{c}\text { Entrepre- } \\
\text { neurial } \\
\text { experience/ } \\
\text { position at } \\
\text { University }\end{array}$ & $\begin{array}{c}\text { Region in } \\
\text { Chile where } \\
\text { university is } \\
\text { located }\end{array}$ & $\begin{array}{c}\text { Year of } \\
\text { experience } \\
\text { teaching } \\
\text { entrepre- } \\
\text { neurship in } \\
\text { University }\end{array}$ & $\begin{array}{l}\text { Background } \\
\text { Degree }\end{array}$ & $\begin{array}{l}\text { Accredita- } \\
\text { tion's } \\
\text { Years per } \\
\text { University }\end{array}$ \\
\hline 1 & Amanda & Female & $\begin{array}{l}\text { Entrepreneur/ } \\
\text { Part-time } \\
\text { professor }\end{array}$ & $\begin{array}{c}\mathrm{RM} \\
\text { (Metroarea) }\end{array}$ & 5 years & $\begin{array}{c}\text { Business } \\
\text { Administration }\end{array}$ & 6 years \\
\hline 2 & Horacio & Male & $\begin{array}{l}\text { Entrepreneur/ } \\
\text { Part-time } \\
\text { professor }\end{array}$ & $\begin{array}{c}\text { RM } \\
\text { (Metroarea) }\end{array}$ & 4 years & $\begin{array}{c}\text { Business } \\
\text { Administration }\end{array}$ & 6 years \\
\hline 3 & Katy & Female & $\begin{array}{l}\text { Entrepreneur/ } \\
\text { Part-time } \\
\text { professor }\end{array}$ & $\begin{array}{c}\text { IV } \\
\text { (north) }\end{array}$ & 4 years & $\begin{array}{c}\text { Business } \\
\text { Administration }\end{array}$ & 6 years \\
\hline 4 & Jenifer & Female & $\begin{array}{l}\text { Academic/ } \\
\text { Consultant/ } \\
\text { Full time } \\
\text { professor }\end{array}$ & $\begin{array}{c}\text { IV } \\
\text { (north) }\end{array}$ & 6 years & $\begin{array}{c}\text { Business } \\
\text { Administration } \\
\text { and Economy }\end{array}$ & 6 years \\
\hline 5 & Liliana & Female & $\begin{array}{l}\text { Entrepreneur/ } \\
\text { Part time } \\
\text { professor }\end{array}$ & $\begin{array}{c}\mathrm{RM} \\
\text { (Metroarea) }\end{array}$ & 4 years & $\begin{array}{l}\text { Social Work } \\
\text { and Public } \\
\text { Administration }\end{array}$ & 3 years \\
\hline 6 & Manuel & Male & $\begin{array}{l}\text { Entrepreneur/ } \\
\text { Part-time } \\
\text { professor }\end{array}$ & $\begin{array}{c}\text { RM } \\
\text { (Metroarea) }\end{array}$ & 5 years & $\begin{array}{c}\text { Business } \\
\text { Administration }\end{array}$ & 6 years \\
\hline 7 & Ricardo & Male & $\begin{array}{c}\text { Academic/ } \\
\text { Consultant/full } \\
\text { time professor }\end{array}$ & $\begin{array}{c}\mathrm{V} \\
\text { (centre) }\end{array}$ & 6 years & $\begin{array}{c}\text { Business } \\
\text { Administration } \\
\text { and } \\
\text { Engineering }\end{array}$ & 6 years \\
\hline 8 & Sergio & Male & $\begin{array}{c}\text { Entrepreneur/ } \\
\text { Part-time } \\
\text { professor }\end{array}$ & $\begin{array}{c}\mathrm{V} \\
\text { (centre) }\end{array}$ & 15 years & $\begin{array}{c}\text { Business } \\
\text { Administration }\end{array}$ & 5 years \\
\hline
\end{tabular}

$\left(^{*}\right)$ Entrepreneurship faculty' names are pseudonyms to keep their anonymity in this study.

Thematic network analysis. I followed the step-by-step guide of thematic network analysis (Attride-Stirling, 2001) as a way to reveal the themes from the interview transcripts as well as to organize them into a graphical representation named the thematic 
network. The thematic network is a tool for qualitative analysis that involves three stages: (a) the reduction of the text, (b) the exploration of the text, and (c) the integration of the exploration. Figure 6 summarizes the basic steps of this three-stage process for a thematic network analysis of qualitative data.

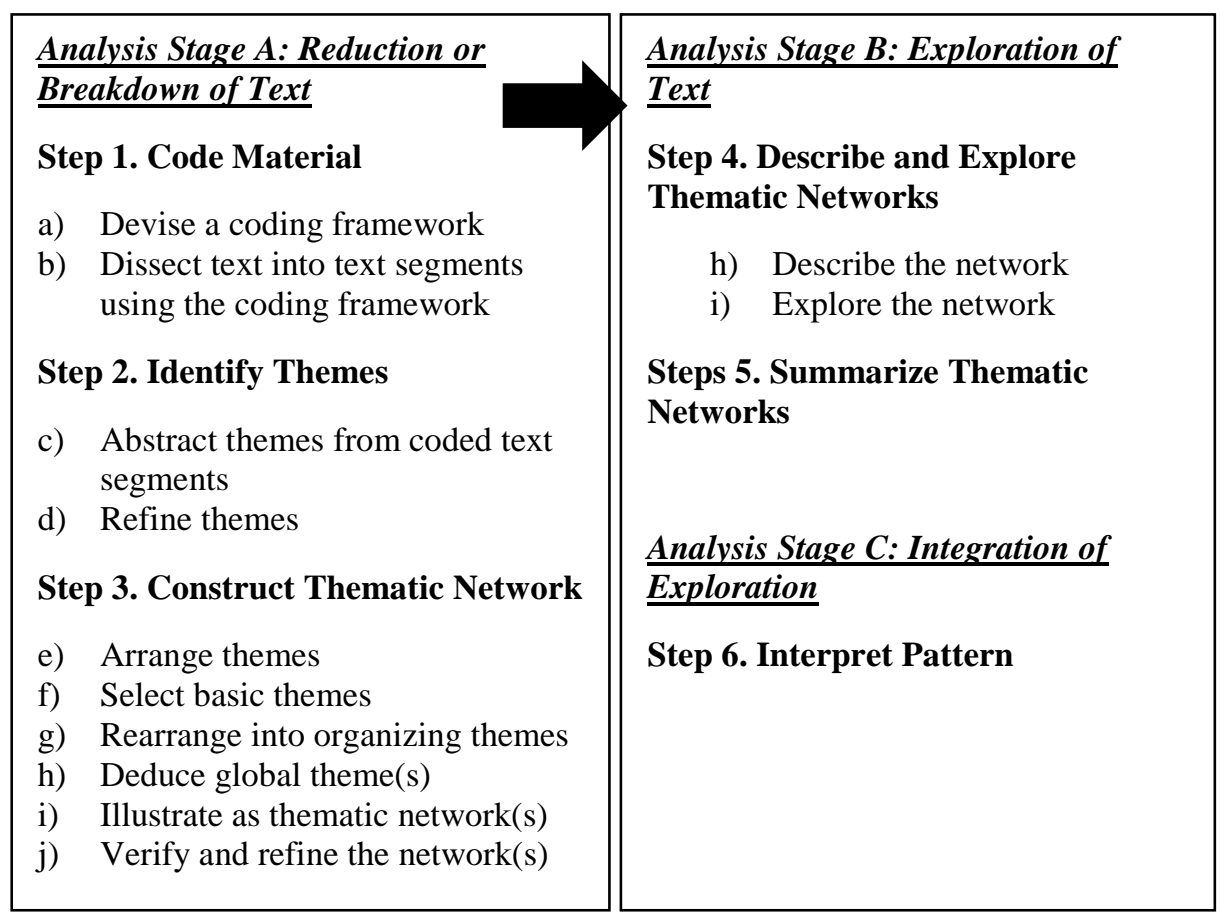

Figure 6. Steps in thematic network analysis. Source: Attride-Stirling, 2001, p. 391.

Stage A: The reduction of the text or breakdown. This first stage implies the preparation of the data for analysis, in order to reduce the data through dissecting the actual text into meaningful text segment using a coding framework. The eight interviews were transcribed. Right after each interview, I spent 30-45 minutes debriefing and writing my reflections about what happened during the interview. I personally transcribed two audio faculty interview keeping literal statements (Merriam, 2009). In addition, I hired a professional transcriber to do the rest of the interview to follow the same procedure that I 
did with the interviews. I listened to the interview transcripts several times and I read all the text in order to have a general sense of the information and an opportunity to reflect on its overall meaning. I wrote notes on the margins during reading transcripts on the issues that arise from the text, highlighted statements, phrases or words that seemed essential about the phenomenon being studied and research questions.

Code material. Coding is the process of organizing the data by bracketing text and writing (Creswell, 2014b). Developing a coding system involves search for topics and patterns into the data; writing down words and comments to represent those patterns (Merriam, 2009). I created a listing of significant statements and words for each interview. The goal was to allow codes to emerge during data analysis. For this research study, I used a manual coding process to analyze the qualitative material on the interviews. The initial coding framework was created from the recurrent issues in the text (Attride-Stirling, 2001). I also used word (C) and excel @ as tools to organize data as well to classify by faculty and across participants to select significant quotes.

Identify themes. Once all the text have been coded, I went again through the text segment and meaningful statement highlighted in order to extract the significant themes. This process allowed me to identify patterns and recurrent issues across participants. Then, I refine themes to reduce the data into a more manageable set of significant themes in order to assemble them into similar groupings. These grouping will become the thematic network.

Construct thematic network. Thematic networks analysis systematizes the extraction of the most lowest-order premises derived from the actual text. These are 
considered the basic themes. Then, the categories of these basic themes grouped together to summarize more abstract principles, named organizing themes, that represent cluster of themes of similar issues. Finally, organizing themes are brought together in line with the basic themes, to illustrate a global theme (see Figure 7). Global themes are macro topics that make sense and represent an argument about a given issue. Once the basic, organizing and global themes are prepared, I produce a thematic network for each global theme. The final objective is to summarize the themes in order to illustrate as nonhierarchical and web-like representation (Attride-Stirling, 2001).

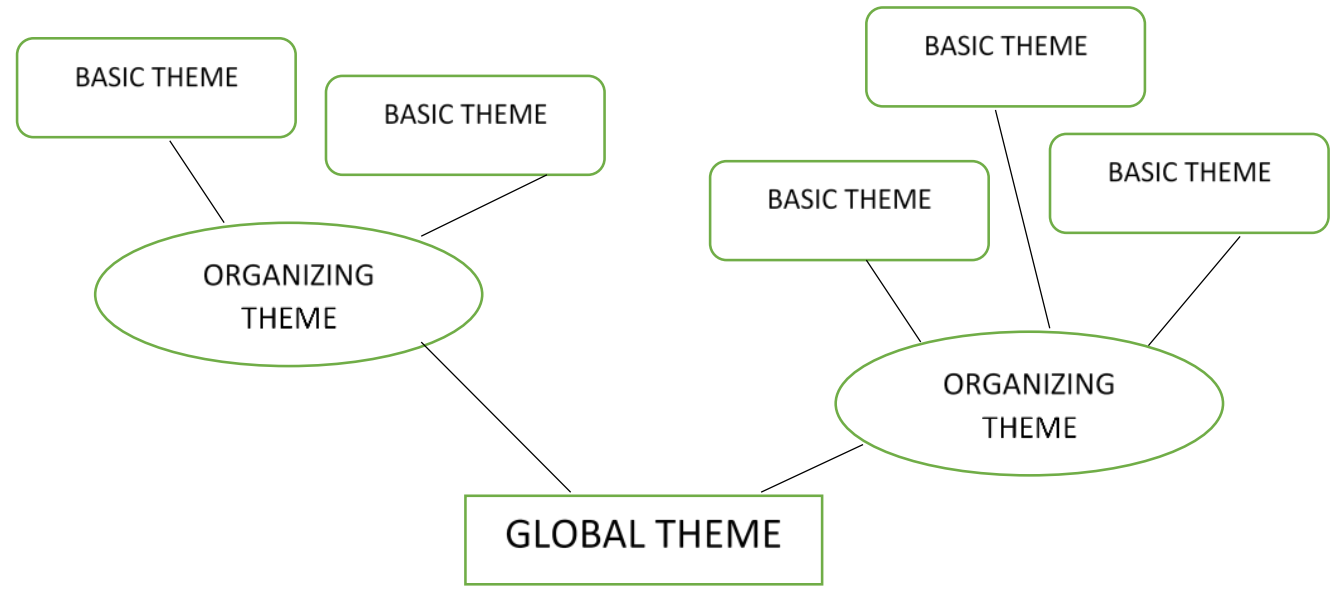

Figure 7. Example of thematic network analysis. Based on Attride-Stirling (2001).

Stage B: The exploration of the text. This step implies the description and exploration of the networks created. The themes that are emerged have to be explored reading the original text, looking for pattern and evidence that support them.

Stage C: The integration of the exploration. This final stage means the interpretation of the patterns founded. The aim of this last sept is to return to research questions and theory applied in the study to addressed them with arguments and evidence. 
These both final stages are part of the analysis of the thematic network that will be described and presented in chapter 4.

\section{Role of the Researcher}

I am from Chile and I grew up with my parents and two younger brothers. I am the first member of my family pursuing a doctoral degree abroad. Even though both of my brothers have college degree, I am the only woman in my entire family close to obtaining an advanced degree outside my country. I graduated with a degree in business management from the Universidad Catolica del Norte, Chile (UCNC). During my college years (1994-1998), I started my career as teaching assistant in the business school, teaching accounting, and finance and management control. Since that time I have been fascinated with the teaching process and how people learn.

In 2004, I was hired as assistant professor at the business school of UCNC in Coquimbo, where I also was program coordinator. In 2005, I lead the process of redesigning the business curricula of UCNC and other four universities to incorporate entrepreneurship content. It was through that experience that I discovered EE as a potential engine to generate social and environmental value rather than just economic. It was at that time that I understood that I needed high level training about teaching and learning in higher education. In 2008, I received a Fulbright scholarship to pursue a doctorate in education at Portland State University.

From my experience in curricula redesign process, I realized that, even though faculty were motivated about these new contents, they lacked training about teaching and pedagogical methods for entrepreneurship and how students learn best. Since that 
moment, I have sought to understand more about the process of teaching in entrepreneurship, how faculty can become better entrepreneurship teachers so we can help better our students to become more entrepreneurial individuals.

I have been working in higher education in Chile for more than 10 years. Even if I do not have real entrepreneurial experience, I do have some specific business management teaching experience as part of my courses taught at UCNC. I do have entrepreneurship experience in a classroom as a student in the Certificate of Social Innovation Entrepreneurship in the Business School of Management at Portland State University. Thus, I feel comfortable in the Chilean setting as well as I feel confident in regards to how to approach entrepreneurship faculty as a professional peer.

I care about the issue of teaching entrepreneurship in universities, In fact, I think it is vital for universities to effectively teach entrepreneurship so that we will have people who can address complex world and social problems. Given my in-depth commitment to $\mathrm{EE}$ and the experience that I have on teaching in higher education in Chile, I realize that I might hold some specific bias in favor of teaching entrepreneurship at university level, therefore I used the following methods in my study to decrease bias and increase validity.

\section{Validity and Trustworthiness}

In this section, I explain the procedures and strategies used for validating findings and minimizing researcher bias.

Researcher's position or reflexivity. I wrote a critical self-reflection (Merriam, 2009) regarding my assumptions and biases about EE and teaching and learning that may affect the investigation. I used my personal journal to do free writing after each 
interviews to clarify my thoughts and to ask question to myself for the next interview. This process allows me to be aware of my bias and assumptions of teaching entrepreneurship at the university level.

Triangulation. I used the same interview guide or protocol for all of the eight faculty interviews for internal consistency. I also used different data sources of information to build a coherent justification of themes (Creswell, 2014b). I used the interview transcripts and the syllabus of the entrepreneurship class that each faculty taught as artifact to analyze.

Member checking. I used member checking to take back to each of the eight faculty participant the interpretations from the interviews (Creswell, 2014b; Merriam, 2009). Specifically, I first solicited their feedback about interviews transcripts. I requested their approval or corrections through email. Just one of the faculty, Amanda, sent me corrections to their interview transcripts that were considered during the process of coding and analysis. This process provided an opportunity for participants to verify the information they shared were accurately transcribed and interpreted. Then, I solicited their feedback about the data, themes, and major findings I have as a result of data analysis from the interviews.

Peer debriefing. The discussion with a colleague who has experience in qualitative data analysis, regarding the process of study was another strategy for promoting validity and reliability (Merriam, 2009). This strategy enhanced accuracy of the qualitative data and the manual coding process specifically. 
Peer coding. I shared my initial coding from two out of the eight interviews with an experienced researcher in $\mathrm{EE}$ in Chile and other with experience in qualitative research here in Portland. These colleagues acted as second coders who confirmed or questioned my interpretations and the categories or themes that I identified.

\section{Research Ethics}

I followed all policies and procedures of Portland State University when conducting this study in an ethical manner, including the Human Subjects Research Review Committee. The final approval for this research study came from Portland State's Institutional Review Board (IRB) on August 20th, 2014. Once approval was granted from IRB, entrepreneurship faculty who met the criteria for selection, were asked if they would be interested in participating in this study. Participants were asked to sign an informed consent form and I assured faculty participants that I protected their confidentiality by using pseudonyms. There was no coercion while recruiting participants and once they choose to participate they were free to withdraw from the study at any time. No students were interviewed in this research study.

\section{Summary}

In this section, I described the rationale for using a MMR approach in conducting this study. A MMR approach integrates quantitative and qualitative methods to answer the five research questions. An explanatory sequential mixed methods design (quan $\rightarrow$ QUAL) was used in this research, which is a type of design in which quantitative data (Phase I; quan) are first collected than qualitative data, analyzed separately, and then merged and integrated with qualitative data (Phase II, QUAL). 
I also identified the eight participants in this research study, presented an overview of the participants and described sampling methods. Procedures for data collection and analysis were explained in detail, which includes the use of statistics such as sample $t$ test for the quantitative data (Creswell, 2014a; Field, 2009), and the steps to coding qualitative data using thematic network analysis (Attride-Stirling, 2001). This chapter concludes with the procedures and strategies for validating the findings. Thus, I am confident that the data analysis conducted for both Phases (quan $\rightarrow$ QUAL) of my research provides evidence to answer the five research questions. 


\section{CHAPTER 4}

\section{ANALYSIS AND RESULTS}

\section{Introduction}

In chapter 3 I explained the research design and the methods chosen to answer my five research questions as well as the rationale for their selection and the protocols applied. I provided an overview of the entrepreneurship faculty participants within this study in Phase II (QUAL). Data collection instruments and data analysis procedures were made clear which also included justifications for their use during both Phases I and II of my study (quan $\rightarrow$ QUAL). Finally, I described strategies used for validating findings and minimizing researcher bias.

Chapter 4, I present data collected and analyzed from both chronological Phases (quan $\rightarrow$ QUAL) in this study. Considering that my research was conducted in two Phases I and II, I organized and interpreted my results chronologically through each of these chronological Phases. Therefore, this chapter 4 is organized under two major headings of data analysis: Phase I (quan) and Phase II (QUAL).

First, I present quantitative data results from Phase I that helped me to respond to research question 1. Second, I present the interpretation of the data result from qualitative Phase II to convey specific findings associated with the purpose of my study and research questions 2 to 5. Lastly, I present a synthesis of results and findings by each Phase (quan $\rightarrow$ QUAL). Chapter 4 ends with the description of the limitations of my study. In the next section, chapter 5, I discuss the major findings of my study and I summarize the results by each of the five research questions. 


\section{Purpose of the Study and Research Questions}

The purpose of this study was twofold: (1) to explore relationships between faculty teaching perspectives and the experience of the faculty and student entrepreneurial intentions in required entrepreneurship courses at Chilean universities. From this information, I identified those faculty who seem to have increased impact on students' entrepreneurial intentions (Phase I: quantitative, secondary data), and (2) to describe and explain how entrepreneurship faculty define and think about EE and teaching methods (Phase II: qualitative, primary data).

The research questions (RQ) for this study were:

RQ1: How do the perspectives (beliefs) about teaching as measured by the TPI and the entrepreneurial experience by faculty in entrepreneurship courses relate to the entrepreneurial intentions level of students in their classes? (quan)

RQ2. How do identified entrepreneurship faculty describe EE? (QUAL)

RQ3. How do identified entrepreneurship faculty describe the relationship between entrepreneurship teaching and entrepreneurial learning? (QUAL)

RQ4. How do identified entrepreneurship faculty describe and explain the selection and the use of pedagogical methods? (QUAL)

RQ5. In what ways do faculty understandings of entrepreneurship teaching and pedagogies (QUAL) help to explain the relationship between faculty perspectives about teaching, the pedagogies they use, and student entrepreneurial intention (quan)? 


\section{Analysis of Data Phase I: Quantitative Phase (quan)}

The goal of Phase I was to analyze and measure the relationship between variables such as (1) the student entrepreneurial intention, (2) faculty's entrepreneurial experience, and (3) teaching perspective profile by the TPI. This data provided numeric information such a descriptive statistics and $t$ test results to respond to research question 1 which is (RQ1): How do the perspectives about teaching (TPI) and the entrepreneurial experience of the faculty relate the student entrepreneurial intention level? In the following sections, I describe these quantitative variables and the correspondence analysis.

\section{Student Entrepreneurial Intentions}

Student's entrepreneurial intention whole sample $(n=2,047)$. I first analyzed

the variable student entrepreneurial intention from the whole sample considering all of the students $(n=2,047)$. This is a secondary data from Albornoz's study on the effect that a required entrepreneurship course had on college student entrepreneurial intentions (Albornoz, 2014). Field (2009) asserts that the $t$ test is a statistic that can be used to compare the difference between the means from two groups within a sample. Specifically, the dependent $t$ test compares two means when those means have come from the same participants and it assumes that the sampling distribution of the difference should be normal. In the case of this variable, I used the $t$ test for a dependent sample or paired sample to compare the differences between the entrepreneurial intention before and after the mandatory entrepreneurship class. Table 7 shows that the actual mean difference in students' entrepreneurial intention between pre and posttest for students in the whole 
sample is not statistically significant, meaning that there is no impact on the students' entrepreneurial intention after taking an entrepreneurship class.

Table 7

Dependent $\mathrm{t}$ test for the Student Entrepreneurial Intention Pre and Posttest $(\mathrm{n}=2,047)$

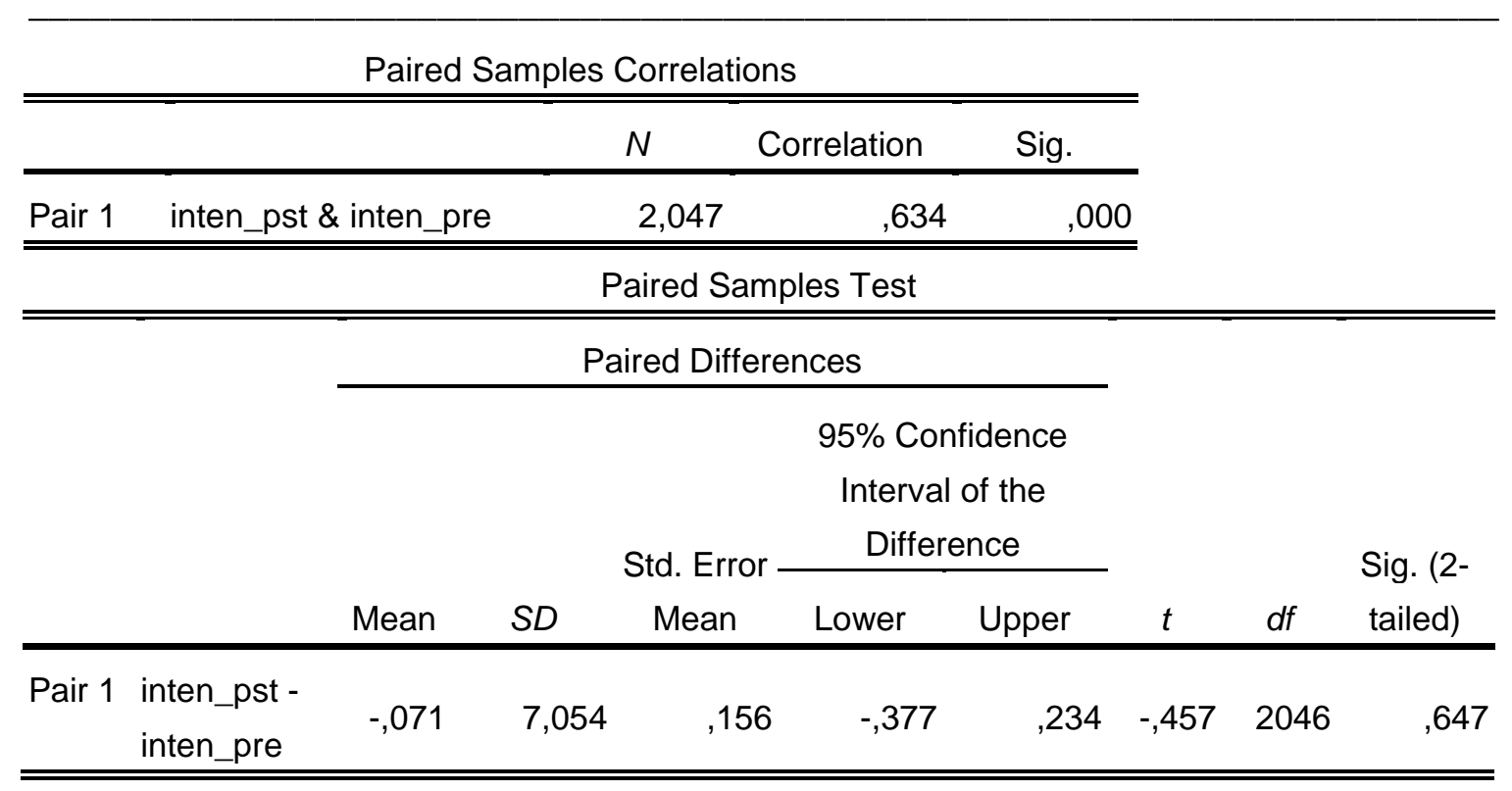

*. Significant at the 0.05 level (2-tailed).

This results means that the effect of a mandatory entrepreneurship course on the college student entrepreneurial intention corresponding to 10 different Chilean universities considered in the sample $(n=2,047)$ is negative but not statistically at 0.05 error level (Albornoz, 2014).

\section{Entrepreneurial intention's antecedents using Azjen's (1991) TPB: (a)}

attitude toward business ownership, (b) perceived behavioral control or self-efficacy, and (c) subjective norm $(n=2,047)$. Table 8 shows the results of the paired sample $t$ test on the effect that an entrepreneurship course has on three dimensions or antecedents 
of the TPB for the whole sample of college students $(n=2,047)$. As we can see in Table 8, a mandatory entrepreneurship course has statistical significant effects on the three dimensions of entrepreneurial intention.

Table 8

Dependent $\mathrm{t}$ test for the Dimensions of the TPB $(\mathrm{n}=2,047)$

\begin{tabular}{|c|c|c|c|c|c|c|c|c|c|}
\hline \multicolumn{10}{|c|}{ Paired Samples Test } \\
\hline & & \multicolumn{5}{|c|}{ Paired Differences } & \multirow{3}{*}{\multicolumn{3}{|c|}{$\begin{array}{l}\text { Sig. (2- } \\
\text { tailed) }\end{array}$}} \\
\hline & & \multicolumn{5}{|c|}{$\begin{array}{c}95 \% \text { Confidence } \\
\text { Interval of the } \\
\text { Difference }\end{array}$} & & & \\
\hline & & Mean & $S D$ & $\begin{array}{l}\text { td. Error } \\
\text { Mean }\end{array}$ & Lower & Upper & & & \\
\hline Pair 1 & $\begin{array}{l}\text { selfeffic_pst - } \\
\text { selfeffic_pre }\end{array}$ & 33,026 & 331,125 & 7,406 & 18,502 & 47,550 & 4,459 & 1998 &, $000^{*}$ \\
\hline Pair 2 & $\begin{array}{l}\text { attd_pst - } \\
\text { attd_pre }\end{array}$ & 0,317 & 4,814 & ,107 &,- 804 &, 528 & 2,954 & 2011 &, $003^{*}$ \\
\hline Pair 3 & $\begin{array}{l}\text { SN_pst - } \\
\text { SN_pre }\end{array}$ & $-6,655$ & 3,920 & ,086 &,- 529 &,- 487 & $-7,626$ & 2081 &, $000^{*}$ \\
\hline
\end{tabular}

*. Significant at the 0.05 level (2-tailed).

The biggest differences are on the mean of the perceived behavioral control or entrepreneurial self-efficacy (Pair 1), which represents the cognitive and skills dimension. The difference between pre and posttest for this variable is in more than 33 points. $(+33.026, p<0.001)$. Thus, the scale of self-efficacy is one of the most important factor in terms of statically significance and it theoretically represents the perceived ability to success as a business owner. Regarding the mean difference on attitudes toward entrepreneurship, the results also show a positive effect and statistical significance $(+.317$, 
$p<0.003)$. The last factor of the entrepreneurial intention is the subjective norm, which also has significant change in the mean but this impact is negative $(-6.655, p<0.001)$.

Even though the effect of a mandatory entrepreneurship course on college students' entrepreneurial intention from the whole sample is not statistically significant (see Table 7), the entrepreneurship class does have impact on the entrepreneurial intention's antecedents. In sum, for the whole sample $(n=2,047)$ the variable perceived behavioral control and attitude toward entrepreneurship have positive effects on the entrepreneurial intention, however, the subjective norm has a negative impact.

Student's entrepreneurial intention subsample student-faculty $(\boldsymbol{n}=\mathbf{2 7 0})$. As I mentioned in chapter 3 , a new database $(n=270)$ was created as a result of a combination between the college student database $(n=2,047)$ and the entrepreneurship faculty database $(n=48)$. Table 9 shows the dependent $t$ test or paired sample for the variable student entrepreneurial intention before and after taking an entrepreneurship course $(n=270)$. The $t$ test shows that the difference in the mean is not statistically significant. In sum, the entrepreneurial intention of the college students do not change because the value is not statistically significant. In other words, the difference on the mean is not different from zero.

In Table 9 we can observe that the mean scores on the entrepreneurial intention scale are around 26 points, which range from 6 minimum to 42 maximum points. The mean of the difference between pre and posttest is positive 0.248 , which theoretically means that for the subsample of college students $(n=270)$, they have a medium intensity on the entrepreneurial intention. Specifically, the students for the subsample reaches $62 \%$ 
(26/42) of the entrepreneurial intention according to the scale, but this intention is not statistically significant. Therefore, the mandatory entrepreneurship classes do not have any impact on the student entrepreneurial intention for the subsample of students $(n=270)$. Coincidently, these results are similar to the entrepreneurial intention for the whole sample $(n=2,047)$.

Table 9

Dependent t test or Paired Sample for the Variable Student Entrepreneurial Intention $(\mathrm{n}=270)$

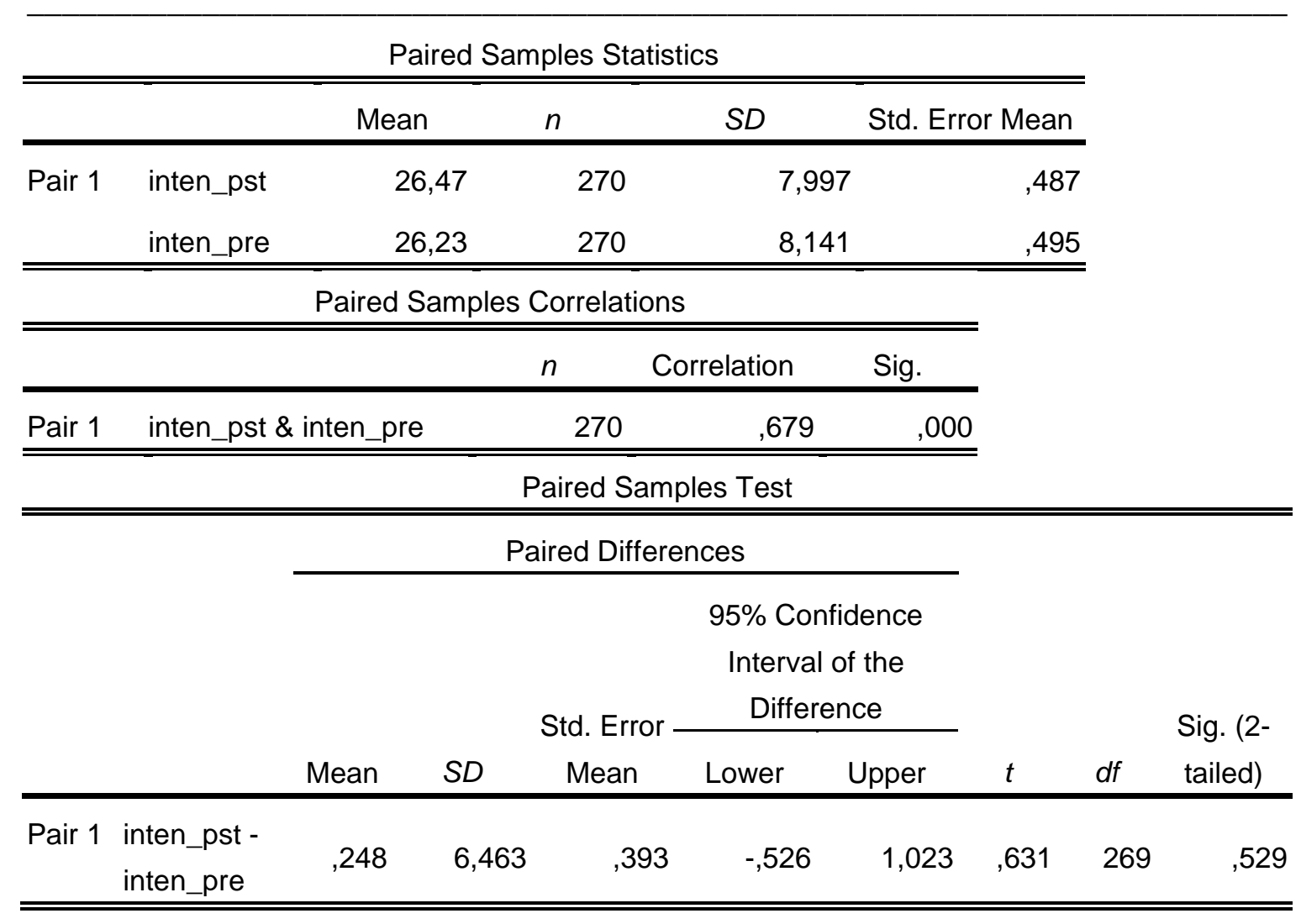

*. Significant at the 0.05 level (2-tailed).

Antecedents of the entrepreneurial intention: (a) attitude toward business ownership, (b) perceived behavioral control or self-efficacy, and (c) subjective norm 
for the subsample student-faculty $(\boldsymbol{n}=\mathbf{2 7 0})$. Table 10 shows the dependent $t$ test which is intended to analyze whether there is statistically significant difference between the mean of these three antecedents of the TPB: self-efficacy toward entrepreneurship, social norm, and entrepreneurial attitude. We can observe that only the mean of the social norm variable is statistically significant and it is reduced by 0.4 points between pre and posttest, as you can see in the row of Pair 2.

The social norm variable aims to explore the social approval and support that a student would receive in deciding to become an entrepreneur. In this subsample $(n=270)$, the variable of self-efficacy and entrepreneurial attitude did not show statistical significance; however, the differences of the means are similar when compared with the whole sample $(n=2,047)$.

In conclusion, the student entrepreneurial intention did not change after taking a mandatory entrepreneurship class, as evidenced by the fact that the results are not statistically significant in both samples of college students $[(n=2,047)$ and $(n=270)]$. However, this mandatory entrepreneurship class does impact the three antecedents of the entrepreneurial intention for the case of the whole sample. Self-efficacy and attitude toward entrepreneurship show the most significant change. In the case of the subsample, these two antecedent of the TPB lost statistical significance but the subjective norm variable maintain it, having a negative impact on the score of the entrepreneurial intention between pre and posttest. 
Table 10

Descriptive Statistics for the Three Factors Related to Entrepreneurial Intention

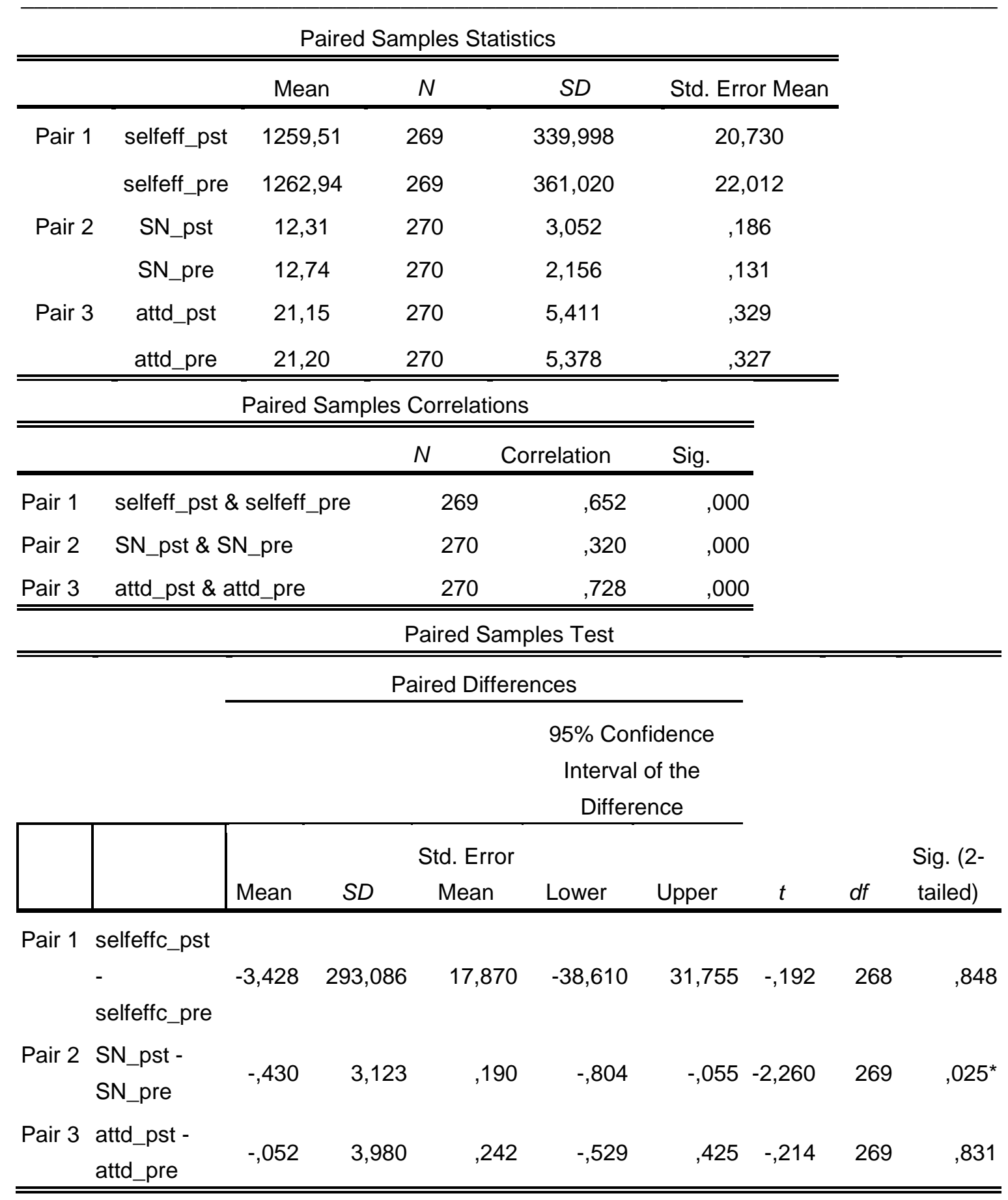

*. Significant at the 0.05 level (2-tailed). 


\section{Faculty's Entrepreneurial Experience}

The variable of faculty entrepreneurial experience summarized responses from a (yes/no) question regarding whether entrepreneurship faculty had owned or currently own a business. Table 11 shows that 13 out of the 18 faculty from the subsample mentioned they had owned a business in the past. The rest of them $(n=5)$ had never owned a business. Focusing on the current entrepreneurial experience, the proportion is different. From the subsample of faculty ( $n=18), 50 \%$ of the sample (9) are current business owners. From these results, I can imply that some of the faculty have closed their business or sold it to others investors.

Table 11

Descriptive Statistics Variable Past and Current Faculty's Entrepreneurial Experience

Have you had owned a business in the past?

\begin{tabular}{rrrrrr}
\hline \hline & & \multicolumn{1}{c}{$f$} & \multicolumn{1}{c}{$\%$} & Valid \% & Cumulative \% \\
\hline Valid & Yes & 13 & 72,2 & 72,2 & 72,2 \\
& No & 5 & 27,8 & 27,8 & 100,0 \\
& Total & 18 & 100,0 & 100,0 & \\
\hline \hline
\end{tabular}

Do you currently own a business?

\begin{tabular}{rrrrrr}
\hline \hline \multirow{2}{*}{ Valid } & \multicolumn{1}{c}{$f$} & \multicolumn{1}{c}{$\%$} & Valid \% & Cumulative \% \\
\cline { 2 - 5 } & Yes & 9 & 50,0 & 50,0 & 50,0 \\
& No & 9 & 50,0 & 50,0 & 100,0 \\
& Total & 18 & 100,0 & 100,0 & \\
\hline \hline
\end{tabular}

Running a crosstabulation between entrepreneurial experience and faculty's gender (see Table 12), from the total of female faculty of the sample $(n=10)$, six female 
faculty had owned a business in the past and four have never been business owners. In the case of male faculty, the proportion is quite different: seven out of eight male faculty have owned a business in the past. From these results, I can say the majority of faculty have had some entrepreneurial experience either in the past or present.

Table 12

Crosstabulation Between Past and Current Entrepreneurial Experience and Faculty's Gender

Crosstabulation Have you had owned a business in the past?* Gender

Frequency (\% of Total)

\begin{tabular}{|c|c|c|c|c|}
\hline & & \multicolumn{2}{|c|}{ Gender } & \multirow[b]{2}{*}{ Total } \\
\hline & & Female & Male & \\
\hline \multirow{2}{*}{$\begin{array}{l}\text { Have you had owned a business } \\
\text { in the past? }\end{array}$} & S Yes & $6(33,3 \%)$ & $7(38,9 \%)$ & $13(72$, \\
\hline & No & $4(22,2 \%)$ & $1(5,6 \%)$ & $5(27, \xi$ \\
\hline \multicolumn{2}{|l|}{ Total } & $10(55,6 \%)$ & $8(44,4 \%)$ & 6) $18(100$ \\
\hline \multicolumn{5}{|c|}{ Crosstabulation Do you currently own a business?* Gender } \\
\hline \multicolumn{5}{|l|}{ Frequency ( $\%$ of Total) } \\
\hline & & \multicolumn{2}{|c|}{ Gender } & \multirow[b]{2}{*}{ Total } \\
\hline & & Female & Male & \\
\hline \multirow{2}{*}{$\begin{array}{l}\text { Do you currently own a } \\
\text { business? }\end{array}$} & Yes & $4(22,2 \%)$ & $5(27,8 \%)$ & $9(50,0 \%)$ \\
\hline & No & $6(33,3 \%)$ & $3(16,7 \%)$ & $9(50,0 \%)$ \\
\hline Total & & $10(55,6 \%)$ & $8(44,4 \%) 18$ & $3(100,0 \%)$ \\
\hline
\end{tabular}




\section{Student entrepreneurial intentions and faculty's past entrepreneurial}

experience. To analyze whether there is a relationship between these two variables, I ran a dependent $t$ test that helps to determine if there is a statistically significant difference between the means of the group of student who had faculty with entrepreneurial experience and the group of student who had faculty without any entrepreneurial experience $(n=270)$.

Table 13 provides a summary of the descriptive statistics of the sample $(n=270)$ of the students identified by the group of students who has classes with a faculty with and without entrepreneurial experience. We can see that 195 out of the total of 270 students from the subsample had classes with faculty members that possess some entrepreneurial experience. The statistical results show that this group of students did not change their entrepreneurial intention after taking the entrepreneurship course because the results are not statistically significant. In contrast, in the case of the group out of 75 students who took a class with a faculty without any entrepreneurial experience, the student entrepreneurial intention increased 2,120 points, from a mean of 23 to 25 points $(+2.120$, $p<0.008)$. For this group, the $t$ test shows that the difference in the means is statistically significant. In sum, the change in the student entrepreneurial intention is only statistically significant for the group of students who have had a faculty without any entrepreneurial experience in the past. 
Table 13

Paired Sample t test Between the Student Entrepreneurial Intention and Faculty Entrepreneurial Experience in the Pas.

\begin{tabular}{|c|c|c|c|c|c|c|}
\hline \multicolumn{7}{|c|}{ Paired Samples Statistics } \\
\hline \multicolumn{3}{|c|}{$\begin{array}{l}\text { Faculty entrepreneurial } \\
\text { experience in the past }\end{array}$} & Mean & $N$ & $S D$ & Std. Error Mean \\
\hline \multirow[t]{2}{*}{ Yes } & Pair 1 & inten_pst & 26,83 & 195 & 8,144 &, 583 \\
\hline & & inten_pre & 27,30 & 195 & 8,079 &, 579 \\
\hline \multirow[t]{2}{*}{ No } & Pair 1 & inten_pst & 25,55 & 75 & 7,574 & ,875 \\
\hline & & inten_pre & 23,43 & 75 & 7,671 & ,886 \\
\hline
\end{tabular}

Paired Samples Correlations

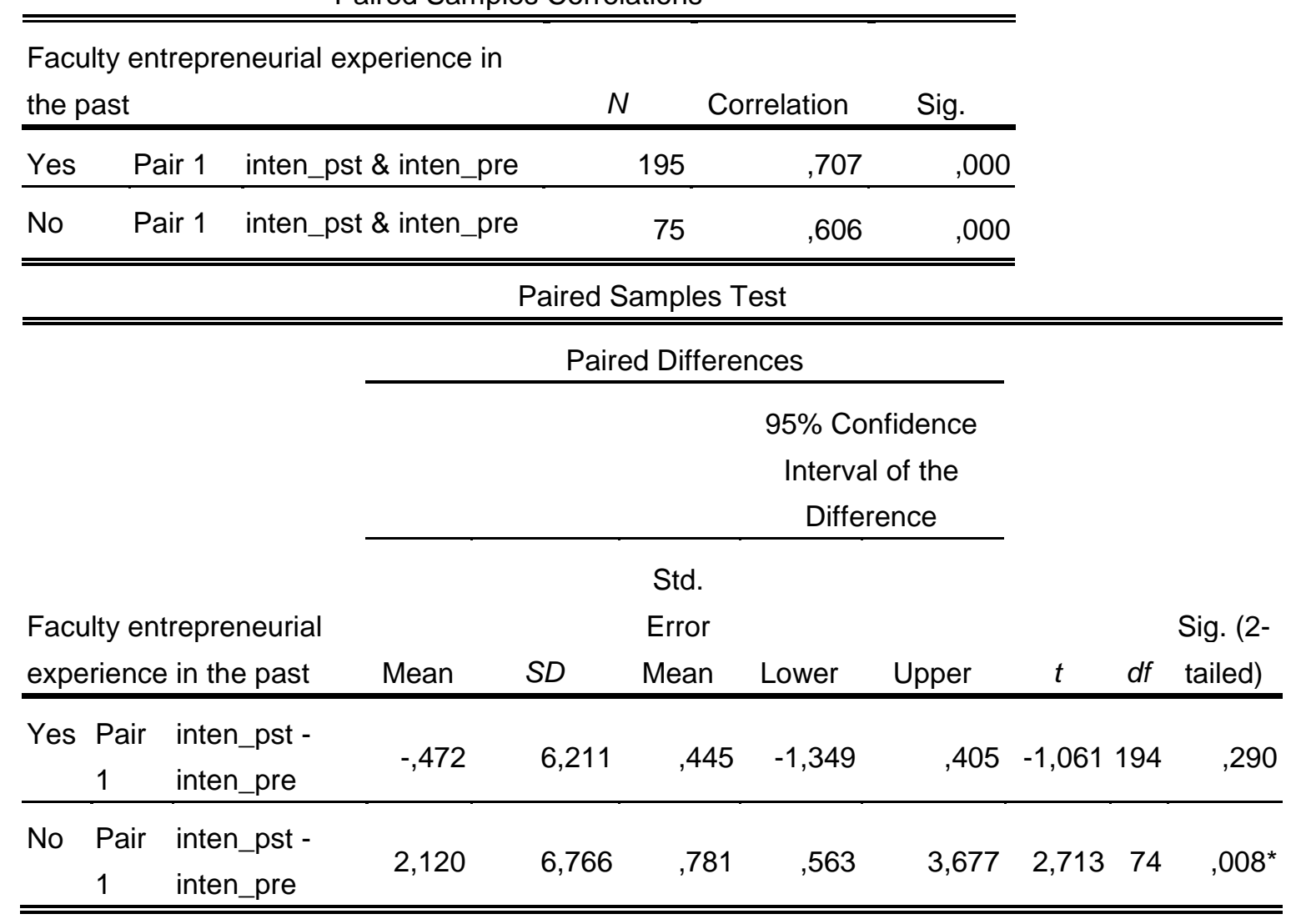

*. Significant at the 0.05 level (2-tailed). 


\section{Student entrepreneurial intentions and current faculty's entrepreneurial}

experience. To analyze whether there is a relationship between these two variables, I ran a dependent $t$ test that helps to determine if there is a statistically significant difference between the means of the group of students who had faculty with current entrepreneurial experience and the group of student who had faculty without any entrepreneurial experience. In the case of the variable current faculty's entrepreneurial experience, the sample changed slightly but the effect on the entrepreneurial intention is similar to the previous case in which the faculty had entrepreneurial experience in the past.

Table 14 provides a summary of the descriptive statistics for the students grouped by the current faculty's entrepreneurial experience. From Table 12, we can see that $50 \%$ of the students had classes with faculty who possess entrepreneurial experience. This group of students $(n=135)$ did not change their entrepreneurial intention after taking the entrepreneurship course. These results are similar with the previous analysis in the case of the past faculty's entrepreneurial experience. In the case of the group of 135 students who had a faculty without current entrepreneurial experience, the student entrepreneurial intention increased in 1.326 points, from a mean of 25 to almost 27 points. For this group, the $t$ test shows that the difference in the means is statistically significant $(+1.327$, $p<0.021)$. 
Table 14

Sample t test Between Current Faculty's Entrepreneurial Experience and Student Entrepreneurial Intention

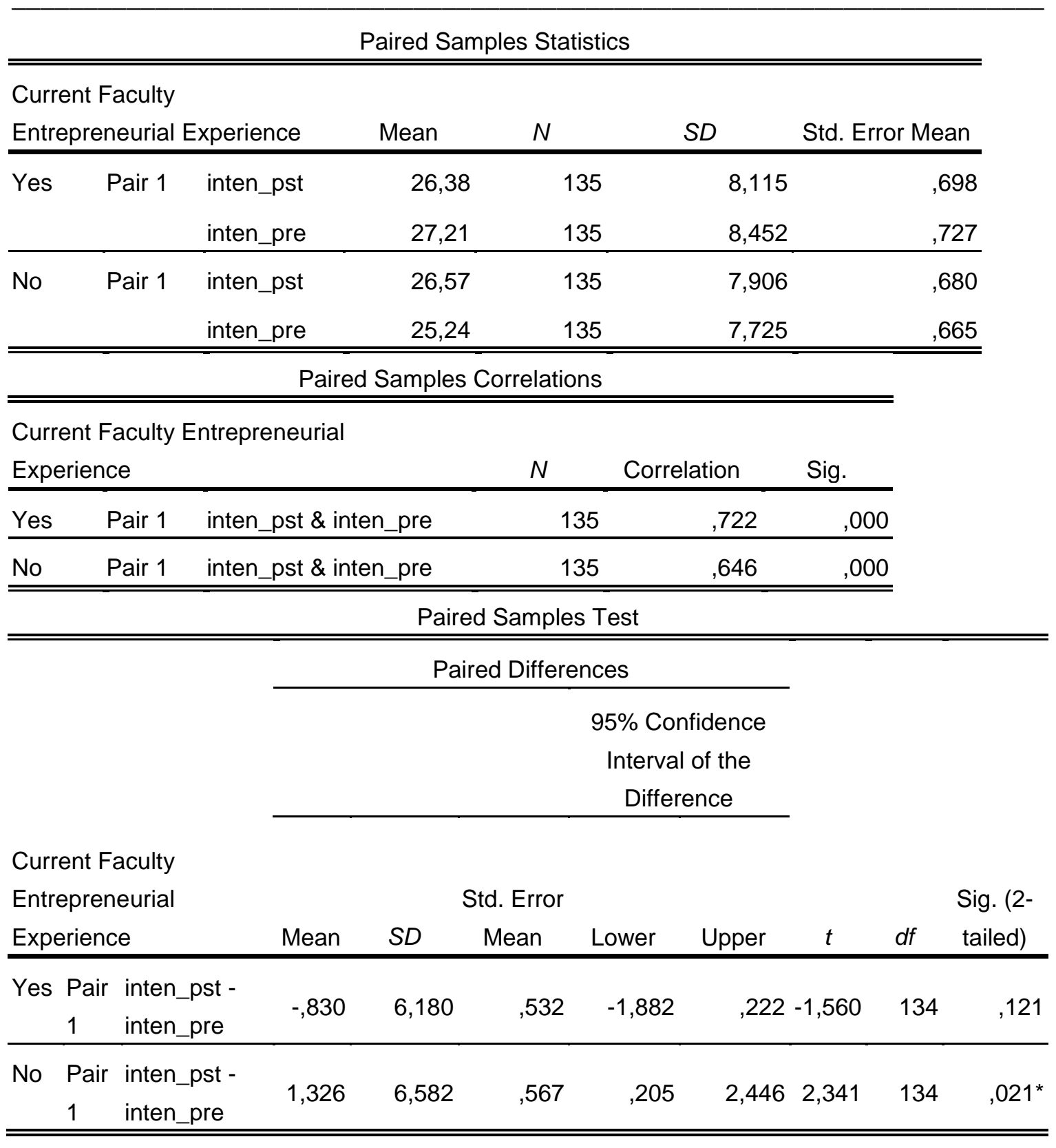

*. Significant at the 0.05 level (2-tailed). 


\section{Differences Between Means of the Student Entrepreneurial Intention as Impacted by Faculty $(n=270)$}

In order to test if there is any relationship between the mean of student entrepreneurial intention after taking the course by each entrepreneurship faculty, I used a dependent $t$ test between the student entrepreneurial intentions grouped by faculty. As Table 15 shows, the mean differences on the student entrepreneurial intention by faculty are different. Some of the faculty (7/18), have a positive impact on the student entrepreneurial intention level, and others (11/18) negatively impact the student entrepreneurial intention. However, even though faculty have different impacts on the student entrepreneurial intention, these mean differences are not statistically significant. It is important to notice that just one of the entrepreneurship faculty (EF14) from the sample $(n=18)$, show an impact on the student entrepreneurial intention which was positive $(+2.933, p<0.034)$ and statistically significant. For the rest of the 17 faculty from the sample, results indicate that there is no statistical significance between the mean differences on the entrepreneurial intention.

Therefore, due to the fact that there is no statistically significant differences between the student entrepreneurial intentions by faculty for the sample $(n=18)$, it could be very interesting and fundamental for the consecutive analysis to test whether the mean of the student entrepreneurial intention by teaching perspective profiles (TPI) of the entrepreneurship faculty are different. In order to do that, I first describe the TPI as a variable and then explain its descriptive statistics. Next, I show the results of the dependent $t$ test that measures the statistical significance of the difference between the five teaching profiles on the student entrepreneurial intention. 
Table 15

Sample t test on the Student Entrepreneurial Intention by Faculty

\begin{tabular}{|c|c|c|c|c|c|c|c|c|c|c|}
\hline \multicolumn{11}{|c|}{ Paired Samples Test } \\
\hline & & & \multicolumn{5}{|c|}{ Paired Differences } & \multirow{3}{*}{\multicolumn{3}{|c|}{$\begin{array}{l}\text { Sig. }(2- \\
\text { tailed) } \\
\end{array}$}} \\
\hline & & & & & & $\begin{array}{r}95 \% \text { Cor } \\
\text { Interval } \\
\text { Differ }\end{array}$ & $\begin{array}{l}\text { fidence } \\
\text { of the } \\
\text { ence }\end{array}$ & & & \\
\hline \multicolumn{3}{|c|}{ Entrepreneurship Faculty } & Mean & $S D$ & $\begin{array}{l}\text { Std. } \\
\text { Error } \\
\text { Mean }\end{array}$ & Lower & Upper & & & \\
\hline EF1 & Pair 1 & $\begin{array}{l}\text { inten_pst - } \\
\text { inten_pre }\end{array}$ &,- 800 & 6,847 & 1,768 & $-4,592$ & 2,992 &,- 452 & 14 & ,658 \\
\hline EF2 & Pair 1 & $\begin{array}{l}\text { inten_pst - } \\
\text { inten_pre }\end{array}$ & ,867 & 9,553 & 2,467 & $-4,424$ & 6,157 & ,351 & 14 & ,731 \\
\hline EF3 & Pair 1 & $\begin{array}{l}\text { inten_pst - } \\
\text { inten_pre }\end{array}$ &,- 400 & 5,998 & 1,549 & $-3,721$ & 2,921 &,- 258 & 14 & 800 \\
\hline EF4 & Pair 1 & $\begin{array}{l}\text { inten_pst - } \\
\text { inten_pre }\end{array}$ &,- 467 & 4,240 & 1,095 & $-2,815$ & 1,882 &,- 426 & 14 & ,676 \\
\hline EF5 & Pair 1 & $\begin{array}{l}\text { inten_pst - } \\
\text { inten_pre }\end{array}$ &,- 867 & 8,467 & 2,186 & $-5,556$ & 3,822 &,- 396 & 14 & ,698 \\
\hline EF6 & Pair 1 & $\begin{array}{l}\text { inten_pst - } \\
\text { inten_pre }\end{array}$ &,- 067 & 6,734 & 1,739 & $-3,796$ & 3,663 &,- 038 & 14 & ,970 \\
\hline EF7 & Pair 1 & $\begin{array}{l}\text { inten_pst - } \\
\text { inten_pre }\end{array}$ & $-1,933$ & 5,351 & 1,382 & $-4,897$ & 1,030 & $\begin{array}{r}- \\
1,399\end{array}$ & 14 & , 184 \\
\hline EF8 & Pair 1 & $\begin{array}{l}\text { inten_pst - } \\
\text { inten_pre }\end{array}$ & $-1,067$ & 4,183 & 1,080 & $-3,383$ & 1,250 &,- 988 & 14 & ,340 \\
\hline EF9 & Pair 1 & $\begin{array}{l}\text { inten_pst - } \\
\text { inten_pre }\end{array}$ & $-2,000$ & 6,199 & 1,601 & $-5,433$ & 1,433 & $\begin{array}{r}- \\
1,250 \\
\end{array}$ & 14 & ,232 \\
\hline EF10 & Pair 1 & $\begin{array}{l}\text { inten_pst - } \\
\text { inten_pre }\end{array}$ &,- 600 & 6,967 & 1,799 & $-4,458$ & 3,258 &,- 334 & 14 & ,744 \\
\hline EF11 & Pair 1 & $\begin{array}{l}\text { inten_pst - } \\
\text { inten pre }\end{array}$ &,- 600 & 5,616 & 1,450 & $-3,710$ & 2,510 &,- 414 & 14 & 685 \\
\hline
\end{tabular}

Table 15 (continued) 


\begin{tabular}{|c|c|c|c|c|c|c|c|c|c|}
\hline \multicolumn{3}{|c|}{ Entrepreneurship Faculty } & \multirow{2}{*}{$\frac{\text { Mean }}{1,667}$} & \multirow{2}{*}{$\frac{S D}{5,205}$} & \multirow{2}{*}{$\begin{array}{c}\text { Std. } \\
\text { Error } \\
\text { Mean }\end{array}$} & \multirow{2}{*}{$\begin{array}{l}\text { Lower } \\
-1,216\end{array}$} & \multirow{2}{*}{$\begin{array}{r}\text { Upper } \\
4,549\end{array}$} & \multirow{2}{*}{$d f$} & $\begin{array}{l}\text { Sig. (2- } \\
\text { tailed) }\end{array}$ \\
\hline EF12 & Pair 1 & $\begin{array}{l}\text { inten_pst - } \\
\text { inten_pre }\end{array}$ & & & & & & & 235 \\
\hline EF13 & Pair 1 & $\begin{array}{l}\text { inten_pst - } \\
\text { inten_pre }\end{array}$ & 2,400 & 8,724 & 2,253 & $-2,431$ & $7,2311,065$ & 14 & ,305 \\
\hline EF14 & Pair 1 & $\begin{array}{l}\text { inten_pst - } \\
\text { inten_pre }\end{array}$ & 2,933 & 4,832 & 1,248 & ,257 & $5,6092,351$ & 14 &, $034^{*}$ \\
\hline EF15 & Pair 1 & $\begin{array}{l}\text { inten_pst - } \\
\text { inten_pre }\end{array}$ & 2,067 & 7,245 & 1,871 & $-1,946$ & $6,0791,105$ & 14 & ,288 \\
\hline EF16 & Pair 1 & $\begin{array}{l}\text { inten_pst - } \\
\text { inten_pre }\end{array}$ &,- 200 & 3,783 & ,977 & $-2,295$ & 1,895 -,205 & 14 & 841 \\
\hline EF17 & Pair 1 & $\begin{array}{l}\text { inten_pst - } \\
\text { inten_pre }\end{array}$ & 1,533 & 7,846 & 2,026 & $-2,811$ & 5,878 ,757 & 14 & ,462 \\
\hline EF18 & Pair 1 & $\begin{array}{l}\text { inten_pst - } \\
\text { inten_pre }\end{array}$ & 2,000 & 5,682 & 1,467 & $-1,147$ & $5,1471,363$ & 14 & ,194 \\
\hline
\end{tabular}

*. Significant at the 0.05 level (2-tailed).

\section{TPI}

As I described in detail in chapter 3, the TPI is a 45-item instrument that assess the orientation to teaching (Pratt, 1998). Responses from the TPI identify dominant views of teaching from the five different perspectives on teaching that include: transmission, apprenticeship, developmental, nurturing, and social reform (see Appendix A for a description of each five teaching perspective). The perspective that scores the highest becomes the dominant perspective of teaching for the faculty. The TPI measures faculty's profiles on these five views of teaching (Pratt, Collins, \& Selinger, 2001) where each 
perspective represents a philosophical orientation toward knowledge, learning, and the social role of teaching.

In order to respond to the question of whether there is any relationship between the perspective of teaching by entrepreneurship faculty and the student entrepreneurial intention, I first observed and analyzed the descriptive statistic of the TPI as a variable in the subsample $(n=270)$. Table 16 shows the descriptive statistics of the TPI. You can see in Table16 that there are little differences between the mean of the five teaching perspectives. However, the apprenticeship profile shows the highest mean score $(39,22)$ with a standard deviation of 3,332 compared to the rest of profiles, followed by the nurturing profile $(37,94)$ with a standard deviation of 3.873 . The third highest mean profile corresponding to the developmental profile which value is 36,39 with a standard deviation of 5.077 .

Table 16

Descriptive Statistics on TPI

\begin{tabular}{lccccr}
\hline \hline & Mean & $N$ & Minimum & Maximum & SD \\
\hline Apprenticeship profile & 39,22 & 270 & 31 & 45 & 3,332 \\
Nurturing profile & 37,94 & 270 & 32 & 45 & 3,873 \\
& & & 24 & 45 & 5,077 \\
Developmental profile & 36,39 & 270 & & & 6,126 \\
Transmission profile & 35,94 & 270 & 26 & 45 & 5,750 \\
Social reform profile & 34,94 & 270 & 18 & 45 & \\
Valid $N$ (listwise) & & $270^{*}$ & & \\
\hline \hline
\end{tabular}


To test whether these mean differences of the five different profiles in the subsample are statistically significant, I used $t$ test for a dependent sample or paired sample. The statistically significant mean differences of the variable TPI are showed in the following Table 17. The mean differences between the five different teaching profiles are statistically significant for this sample $(n=270)$. The only exception is for the difference between the profile transmission and developmental (Pair 2, second row) that shows that the $t$ test is not statistically significant.

We can also see that the major difference is between the apprenticeship and social reform profiles. The mean difference is 4.278 points. The followed mean difference from the teaching profiles is between nurturing and social reform (Pair 10, last row). The $t$ test for this pair shows that also is statistically significant $(+3.000, p<0.001)$.

These differences are reinforced by the non-parametric test to measure mean differences for related samples, expressed as Friedman Chi-Square with a bilateral significance with a $p$-value $0.001<0.05 \alpha$-level (see Table 18) 
Table 17

t test Paired Sample, Variable TPI

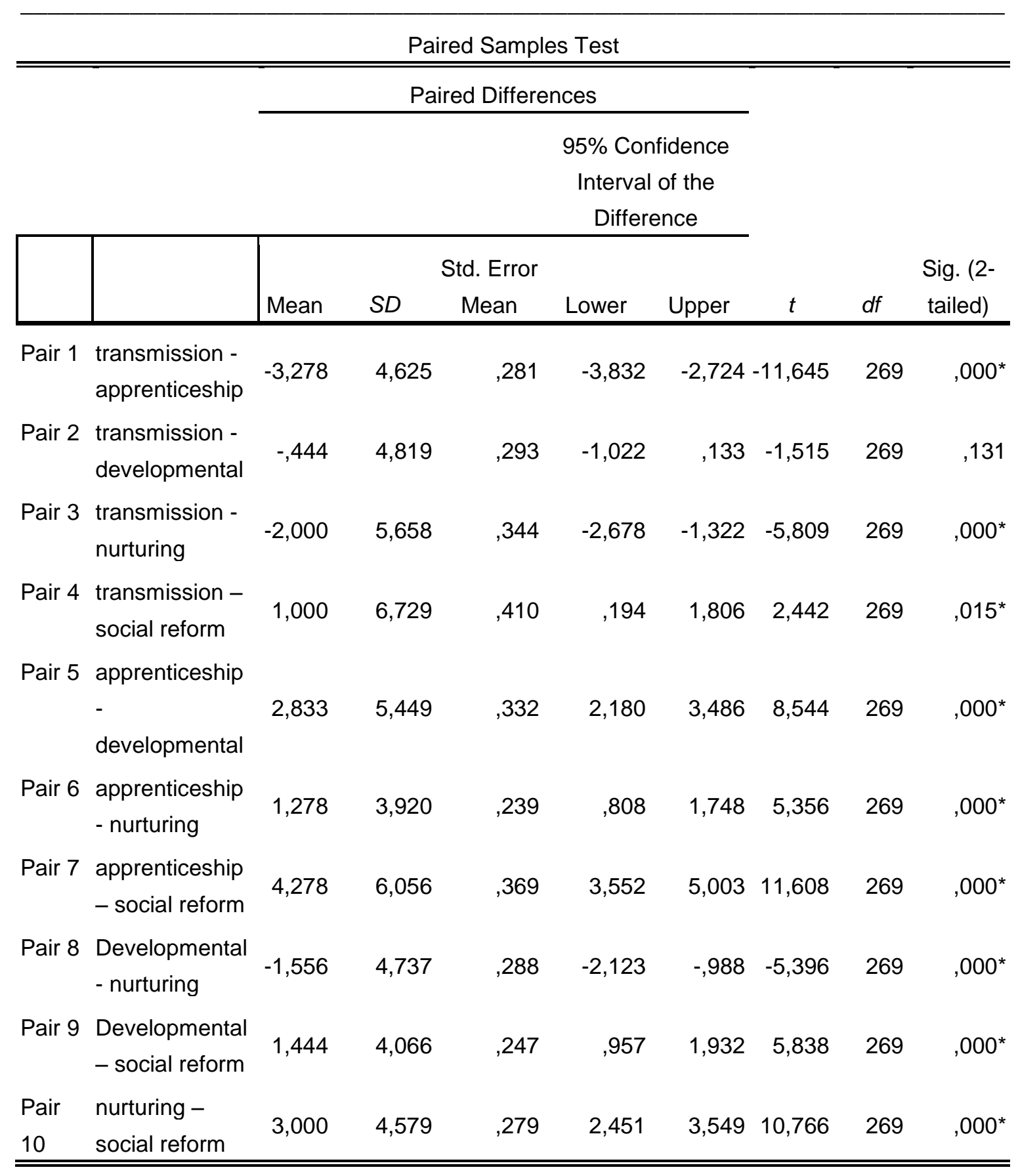

*. Significant at the 0.05 level (2-tailed). 
Table 18

Chi-Square Test

\begin{tabular}{ll}
\multicolumn{2}{l}{ Test Statistics $^{\mathrm{a}}$} \\
\hline$N$ & 270 \\
Chi-Square & 174,182 \\
$d f$ & 4 \\
Asymp. Sig. &, 000 \\
\hline \hline
\end{tabular}

a. Friedman Test

In the next section, I describe the results from the $t$ test to see if there is any impact on student entrepreneurial intention in relation to each teaching perspective profile.

Student entrepreneurial intention and teaching perspectives. To determine whether there is a statistically significant difference between the means of the five different teaching profiles in terms of the mean differences of the student entrepreneurial intention, I used a one-way ANOVA test (see Table 17). Fields (2009) defined the analyses of variance (ANOVA) as a statistical model used to analyze situations in which we want to compare more than two conditions or groups of people. In fact, an ANOVA test tells us whether three or more means are the same through testing the null hypothesis that all group means are equal. In addition, an ANOVA test makes three important assumptions: that the variances in each condition need to be similar, that the observations should be independent and, that the distributions within groups are normally distributed.

In this case, the independent variable is the type of teaching perspective profile because we have five different categories in which each faculty might have high scores 
on: Transmission, Apprenticeship, Developmental, Nurturing, and Social Reform. The dependent variable or outcome is the difference between pre and posttest on student entrepreneurial intention scores. The one-way ANOVA test allows me to analyze and answer this question: are the means of these five teaching profiles statistically significant in terms of student entrepreneurial intention? In other words, does the type of faculty's teaching profile influence student entrepreneurial intention level? In Table 19 we can observe that there are no significant differences between the different five teaching profiles. The statistical significance is superior to the $0.05 \alpha$-level. Thus, there is no statistical difference between the means of the groups of the students with regard to faculty's teaching perspectives. Thus, the student entrepreneurial intention is not impacted by the teaching perspective of the faculty who taught the class have.

Table 19

ANOVA Test Between Teaching Perspective Profile and Student Entrepreneurial Intentions

\begin{tabular}{|c|c|c|c|c|c|c|c|}
\hline \multicolumn{8}{|c|}{ ANOVA Table } \\
\hline & & & $\begin{array}{l}\text { Sum of } \\
\text { Squares }\end{array}$ & $d f$ & $\begin{array}{l}\text { Mean } \\
\text { Square }\end{array}$ & $F$ & Sig. \\
\hline \multirow{5}{*}{$\begin{array}{l}\text { dif_inten * } \\
\text { Transmission }\end{array}$} & Between & (Combined) & 474,807 & 11 & 43,164 & 1,035 & ,416 \\
\hline & Groups & Linearity & 3,834 & 1 & 3,834 & ,092 & ,762 \\
\hline & & $\begin{array}{l}\text { Deviation from } \\
\text { Linearity }\end{array}$ & 470,974 & 10 & 47,097 & 1,129 & ,341 \\
\hline & \multicolumn{2}{|c|}{ Within Groups } & 10761,567 & 258 & 41,711 & & \\
\hline & \multicolumn{2}{|l|}{ Total } & 11236,374 & 269 & & & \\
\hline
\end{tabular}


Table 19 (continued)

\begin{tabular}{|c|c|c|c|c|c|c|c|c|}
\hline & & & $\begin{array}{l}\text { Sum of } \\
\text { Squares }\end{array}$ & $d f$ & $\begin{array}{l}\text { Mean } \\
\text { Square }\end{array}$ & $F$ & Sig. & \\
\hline \multirow{6}{*}{$\begin{array}{l}\text { dif_inten * } \\
\text { Apprenticeship }\end{array}$} & Between & (Combined) & 314,452 & 8 & 39,306 & ,939 & ,484 & \\
\hline & Groups & Linearity & 4,343 & 1 & 4,343 & 104 & ,748 & \\
\hline & & $\begin{array}{l}\text { Deviation from } \\
\text { Linearity }\end{array}$ & 310,109 & 7 & 44,301 & 1,059 & ,391 & \\
\hline & Within Grc & ups & 10921,922 & 261 & 41,846 & & & \\
\hline & Total & & 11236,374 & 269 & & & & \\
\hline & & & $\begin{array}{l}\text { Sum of } \\
\text { Squares }\end{array}$ & $d f$ & $\begin{array}{l}\text { Mean } \\
\text { Square }\end{array}$ & $F$ & Sig. & \\
\hline \multirow{6}{*}{$\begin{array}{l}\text { dif_inten * } \\
\text { Developmental }\end{array}$} & Between & (Combined) & 422,607 & 12 & 35,217 & $7 \quad, 837$ & ,612 & \\
\hline & Groups & Linearity & 109,644 & 1 & 109,64 & $4 \quad 2,606$ & 108 & \\
\hline & & $\begin{array}{l}\text { Deviation from } \\
\text { Linearity }\end{array}$ & 312,964 & 11 & 28,45 & ;1 676 & ,761 & \\
\hline & Within Gro & ups & 10813,767 & 257 & 42,077 & & & \\
\hline & Total & & 11236,374 & 269 & & & & \\
\hline & & & $\begin{array}{l}\text { Sum } \\
\text { Squar }\end{array}$ & & $d f$ & $\begin{array}{l}\text { Mean } \\
\text { Square }\end{array}$ & $F$ & Sig. \\
\hline \multirow{5}{*}{$\begin{array}{l}\text { dif_inten * } \\
\text { Nurturing }\end{array}$} & Between & (Combined) & 211 & 896 & 10 & 21,190 & ,498 & ,891 \\
\hline & Groups & Linearity & 32 & 434 & 1 & 32,434 & ,762 & ,384 \\
\hline & & $\begin{array}{l}\text { Deviation fro } \\
\text { Linearity }\end{array}$ & m & 463 & 9 & 19,940 & ,468 & ,895 \\
\hline & Within G & oups & 11024 & 478 & 259 & 42,566 & & \\
\hline & Total & & 11236 & 374 & 269 & & & \\
\hline
\end{tabular}


Table 19 (continued)

\begin{tabular}{|c|c|c|c|c|c|c|c|}
\hline & & & $\begin{array}{l}\text { Sum of } \\
\text { Squares }\end{array}$ & $d f$ & $\begin{array}{l}\text { Mean } \\
\text { Square }\end{array}$ & $F$ & Sig. \\
\hline dif_inten * & Between & (Combined) & 392,230 & 11 & 35,657 & ,848 &, 592 \\
\hline \multirow[t]{4}{*}{ Social Reform } & Groups & Linearity & 19,245 & 1 & 19,245 & ,458 & ,499 \\
\hline & & $\begin{array}{l}\text { Deviation from } \\
\text { Linearity }\end{array}$ & 372,985 & 10 & 37,298 & ,887 & ,546 \\
\hline & \multicolumn{2}{|c|}{ Within Groups } & 10844,144 & 258 & 42,032 & & \\
\hline & \multicolumn{2}{|l|}{ Total } & 11236,374 & 269 & & & \\
\hline
\end{tabular}

In addition, the Kendall's test also shows that there is not a significant correlation between the teaching perspectives profile (TPI) and the differences in the mean differences in student entrepreneurial intention as you can see in Table 20.

Table 20

Correlation Between the Five Different Teaching Perspectives Profile and Differences in Student Entrepreneurial Intention

\begin{tabular}{|c|c|c|c|c|c|c|c|}
\hline \multicolumn{3}{|c|}{ Correlations } & \multirow{2}{*}{$\begin{array}{r}\text { Transm } \\
, 014\end{array}$} & \multirow{2}{*}{$\begin{array}{r}\text { Apprent } \\
-, 002\end{array}$} & \multirow{2}{*}{$\begin{array}{r}\text { Develop } \\
, 075\end{array}$} & \multirow{2}{*}{$\begin{array}{r}\text { Nurturing } \\
, 041\end{array}$} & \multirow{2}{*}{$\begin{array}{l}\text { Social } \\
\text { Reform } \\
, 025\end{array}$} \\
\hline Kendall's tau_b & Intention & $\begin{array}{l}\text { Correlation } \\
\text { Coefficient }\end{array}$ & & & & & \\
\hline & & $\begin{array}{l}\text { Sig. }(2- \\
\text { tailed) }\end{array}$ & ,741 & ,970 & ,084 & ,348 &, 563 \\
\hline & & $N$ & 270 & 270 & 270 & 270 & 270 \\
\hline
\end{tabular}

\section{Summary of the Primary Results in Phase I (quan)}

In summary, Phase I allowed me to analyze statistically two different databases (students and faculty) as well as to create a new dataset with 270 valid data paired from student and faculty. Analyzing the whole sample of students $(n=2,047)$ and this new 
database as a subsample $(n=270)$ through statistical analysis using dependent $t$ test, results demonstrate that the mandatory entrepreneurship class had an impact on the students' entrepreneurial intentions; however, it was not statistically significant for the sample of college students in Chilean universities. Table 21 summarizes the impact that a mandatory entrepreneurship class has on the student entrepreneurial intention and its antecedents.

Table 21

Summary of the Impact of the Mandatory Entrepreneurship Course (Difference Between Means Pre and Posttest)

\begin{tabular}{lrr}
\hline $\begin{array}{l}\text { Entrepreneurial intention and its antecedents (attitudes, } \\
\text { perceived behavioral control, and subjective norm) based on } \\
\text { the TPB (Azjen, 1991) }\end{array}$ & $\begin{array}{c}\text { Pre and } \\
\text { posttest }\end{array}$ & $\begin{array}{c}p \text {-value at } \\
0.05 \text { a-level }\end{array}$ \\
\hline Difference in the student entrepreneurial intention $(n=2,047)$ & -0.071 & 0.647 \\
Difference in the student entrepreneurial intention $(n=270)$ & 0.248 & 0.529 \\
Difference in attitudes toward entrepreneurial behavior $(n=2,047)$ & 0.317 & ${ }^{*} 0.003$ \\
Difference in attitudes toward entrepreneurial behavior $(n=270)$ & -0.052 & 0.831 \\
Difference in perceived behavioral control/self-efficacy $(n=2,047)$ & 33.026 & ${ }^{*} 0.001$ \\
Difference in perceived behavioral control/self-efficacy $(n=270)$ & -3.428 & 0.848 \\
Difference in subjective norm $(n=2,047)$ & -6.655 & ${ }^{*} 0.001$ \\
Difference in subjective norm $(n=270)$ & -0.430 & ${ }^{*} 0.025$ \\
\hline
\end{tabular}

*. Significant at the 0.05 level (2-tailed).

Regarding the dimensions or antecedents of the entrepreneurial intention based on the TPB (Azjen, 1991), results shows that there is statistical significance in the three dimensions for the whole sample $(n=2,047)$. Among the elements of the TPB; the selfefficacy or perceived behavioral control, entrepreneurial attitude and social norm, was the variable of perceived behavioral control that shows the major positive change. In the case of the subsample only the variable of perceived subjective norm of the TPB is statistically significant and the impact is negative in almost 0.5 points. 
When relating entrepreneurial intention to the variable of the past or current entrepreneurial experience of the faculty, the results are quite interesting. Table 22 summarizes the results of the dependent $t$ test applied to the entrepreneurial intention and its antecedents which shows statistical significance. In the case of the entrepreneurial intention, students change their intention after taking the entrepreneurship class by more than 2 points when the faculty who taught the class has no entrepreneurial experience in the past. Faculty without current entrepreneurial experience positively impact the entrepreneurial intention of the students by more than 1 point and also this score is statistically significant.

Table 22

Summary of the Impact of the Mandatory Entrepreneurship Course [Difference Between Means Pre and Posttest $(\mathrm{n}=270)]$ Regarding Entrepreneurial Experience by Faculty

\begin{tabular}{lcc}
\hline Variables & $\begin{array}{c}\text { Pre and } \\
\text { posttest }\end{array}$ & $\begin{array}{c}p \text {-value at } \\
0.05 \alpha \text {-level }\end{array}$ \\
\hline $\begin{array}{l}\text { Difference in the student entrepreneurial intention when the faculty } \\
\text { who taught the class has no past entrepreneurial experience }\end{array}$ & 2.120 & ${ }^{*} 0.008$ \\
$\begin{array}{l}\text { Difference in the student entrepreneurial intention when the faculty } \\
\text { who taught the class has no current entrepreneurial experience }\end{array}$ & 1.326 & ${ }^{*} 0.021$ \\
$\begin{array}{l}\text { Difference in attitudes toward entrepreneurial behavior when the } \\
\text { faculty who taught the class has no past entrepreneurial experience }\end{array}$ & 1.187 & ${ }^{*} 0.016$ \\
$\begin{array}{l}\text { Difference in attitudes toward entrepreneurial behavior when the } \\
\text { faculty who taught the class has current entrepreneurial experience }\end{array}$ & -0.667 & ${ }^{*} 0.046$ \\
\hline
\end{tabular}

*. Significant at the 0.05 level (2-tailed).

In the case of the antecedents of the entrepreneurial intention the only case that showed statistical significance is the variable attitude toward entrepreneurial behavior. In summary, students who had classes with a faculty without any entrepreneurial experience in the past, increase in more than 1 point their entrepreneurial attitude. When students in 
the subsample had classes with a faculty with current entrepreneurial experience, the students' entrepreneurial attitude decreased by 0.667 points.

Regarding the results of the student entrepreneurial intention by each of the 18 faculty, the $t$ test shows that the entrepreneurial intention of the students are different, but that just one faculty case was statistically significant. In other words, some of the faculty (7/18) have a positive impact on the student entrepreneurial intention level and others $(11 / 18)$ negatively impact the student entrepreneurial intention. Thus even though faculty have different impacts on student entrepreneurial intention, these mean differences are not statistically significant.

To understand whether there is relationship between the student entrepreneurial intention and the faculty's teaching profile, I used an ANOVA test. Results also demonstrate that there is no statistically significant different between means on the entrepreneurial intention of the students. Even though faculty $(n=18)$ have different impacts on the student entrepreneurial intention because some of them increase students' intentions and other decrease it, I cannot conclude that a faculty might impact the student entrepreneurial intention more or less due to the lack of statistical significance. Therefore, I decided to consider the whole sample of faculty $(n=18)$ as probable participants for Phase II (QUAL) to be interview. Only one of them has an impact on the entrepreneurial intention statistically significant.

All of these statistical results allowed me to select a subsample of entrepreneurship faculty as probable participants for the Phase II (QUAL) to conduct semi-structured interviews using purposive sampling as I detailed in chapter 3. From the 
subsample $(n=270), 18$ entrepreneurship faculty met the criteria to be interviewed. These 18 entrepreneurship faculty, according to the statistical analysis, impacted differently the entrepreneurial intention of the student subsample. Finally, these results also allowed me to respond research question 1, which results I present in chapter 5.

In the following section, I describe all of the procedures involved in data collection and analysis on Phase II (QUAL) of this research that permit me to respond to research question 2 to 5 , which are presented in chapter 5 .

\section{Analysis of Data Phase II: Qualitative Phase (QUAL)}

The goal of this Phase II was to conduct semi-structured interviews from those faculty who were in the subsample $(n=270)$. I conducted eight individual in-depth interviews with entrepreneurship faculty using the same protocol (see Appendix F) to obtain their specific views and hear their voices in more detail about the phenomenon of teaching entrepreneurship in university courses. This primary data collected helped me to describe and explain how faculty make meaning of $\mathrm{EE}$ and their teaching practices. I also asked them to bring their syllabi from their entrepreneurship courses. I considered these syllabi as another source of information to analyze.

\section{Overview Participants Interviewed}

Table 23 describes demographic information from the participants interviewed. The total of eight faculty represented six different Chilean universities from different geographical regions. A total of four faculty are female and four male. Most of them have degree in business administration and six of the eight have been entrepreneurs or are currently entrepreneurs. Also, the last column of Table 23 shows the results of the $t$ test between the means of the student entrepreneurial intention after taking an 
entrepreneurship. Results shown that just one of the faculty participants (Jenifer) has a positive and statistically significant impact on the intention of the students. In the rest of the faculty cases, the means on the entrepreneurial intention are different in its value but are not statistically significant.

Table 23

Overview of Interviewed Participants

\begin{tabular}{ccccccc}
\hline Name* & Gender & $\begin{array}{c}\text { Entrepreneurial } \\
\text { experience }\end{array}$ & Age & $\begin{array}{c}\text { Year of } \\
\text { experience } \\
\text { teaching } \\
\text { entrepreneurship } \\
\text { in University }\end{array}$ & $\begin{array}{c}\text { Change on the mean } \\
\text { of the student } \\
\text { entrepreneurial } \\
\text { intention between pre } \\
\text { and posttest }\end{array}$ \\
\hline 1 & Amanda & Female & Entrepreneur & 34 & 5 years & -.800 \\
2 & Horacio & Male & Entrepreneur & 27 & 4 years & -.867 \\
3 & Katy & Female & Entrepreneur & 39 & 4 years & -.067 \\
4 & Jenifer & Female & Academic- & 46 & 6 years & $+2.933^{* *}$ \\
5 & Liliana & Female & Entrepreneur & 38 & 4 years & -1.933 \\
6 & Manuel & Male & Entrepreneur & 38 & 5 years & -2.000 \\
7 & Ricardo & Male & Academic- & 57 & 6 years & +2.067 \\
& & & Consultant & & & -.200 \\
\hline 8 & Sergio & Male & Entrepreneur & 73 & 15 years & \\
\hline
\end{tabular}

$\left(^{*}\right)$ Entrepreneurship faculty' names are pseudonyms to keep their anonymity in this study.

(**) Significant at the 0.05 level (2-tailed).

\section{Thematic Network Analysis}

In this qualitative Phase II, I followed the step-by-step guide of thematic network analysis (Attride-Stirling, 2001) as a tool that helped me reveal the themes from the interview transcripts as well as to organize them into a graphical representation called the thematic network. I used a manual coding process to analyze the qualitative material in 
the interviews. The initial coding framework was created from the recurrent issues in the text as was explained in detail in chapter 3. Once all the text had been coded, I went through the text segment again and highlighted meaningful statements in order to extract the significant themes. I also used word and Excel as tools to organize the basic themes first, and then to select from the interview transcripts the significant statement from participants and across participants.

I looked for patterns in order to find basic and organizing themes, first individually within each participant's transcript and then across all eight participants' data (see Figure 8). This process allowed me to identify patterns and recurrent issues from the qualitative data. I was interested in the themes that were common through all participants.

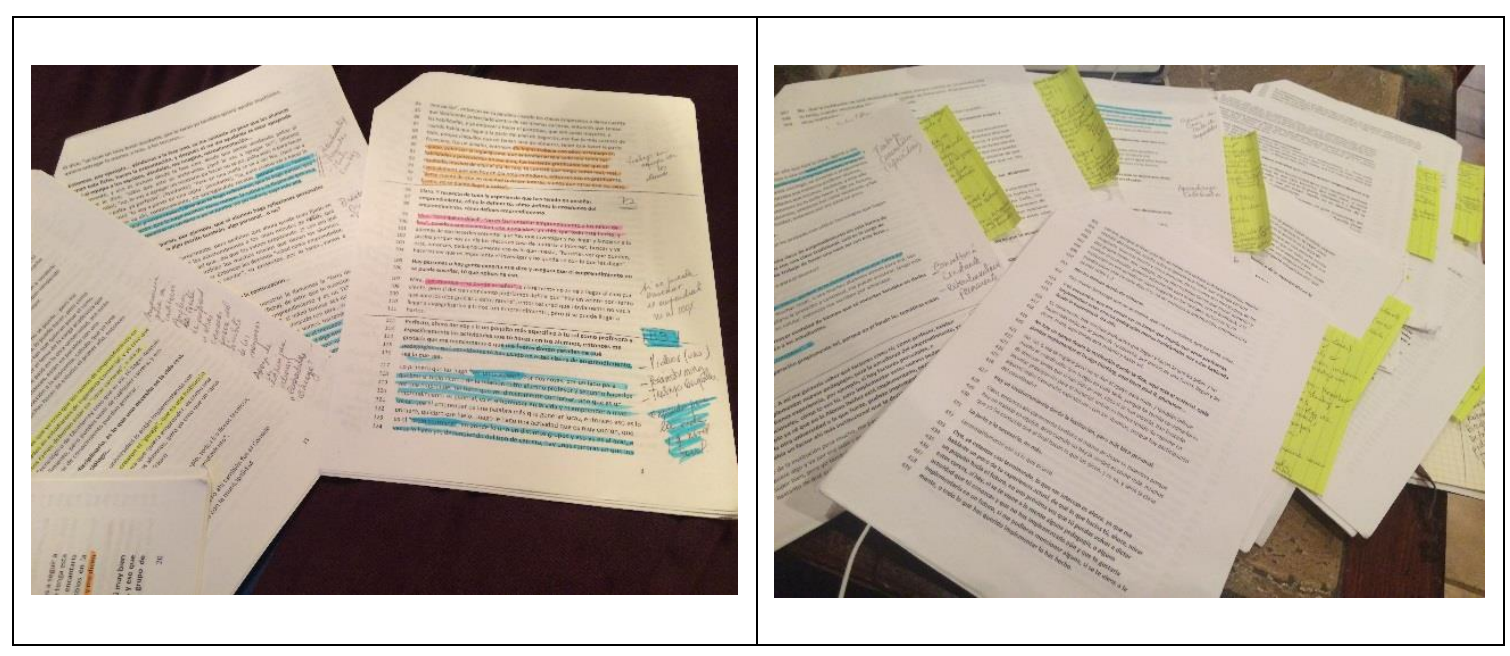

Figure 8. Photos of the process of manual coding in this research using the step by step guide of thematic network analysis. Source: Attride-Stirling (2001).

I then refined the themes to reduce the data into a more manageable set of significant themes in order to assemble them into similar groupings. According to 
Attride-Stirling (2001), thematic network analysis systematizes the extraction of the lowest-order premises derived from the actual text. These are considered the basic themes. Then, the categories of these basic themes grouped together to summarize more abstract principles, are called organizing themes, which represent clusters of themes of similar issues. Global themes are macro topics that make sense and represent an argument about a given issue.

As I mentioned in chapter 3, once all the texts have been coded, I went through the text segment again and highlighted meaningful statements in order to extract the significant themes. This process allowed me to identify patterns and recurrent issues across participants (see Figure 9).

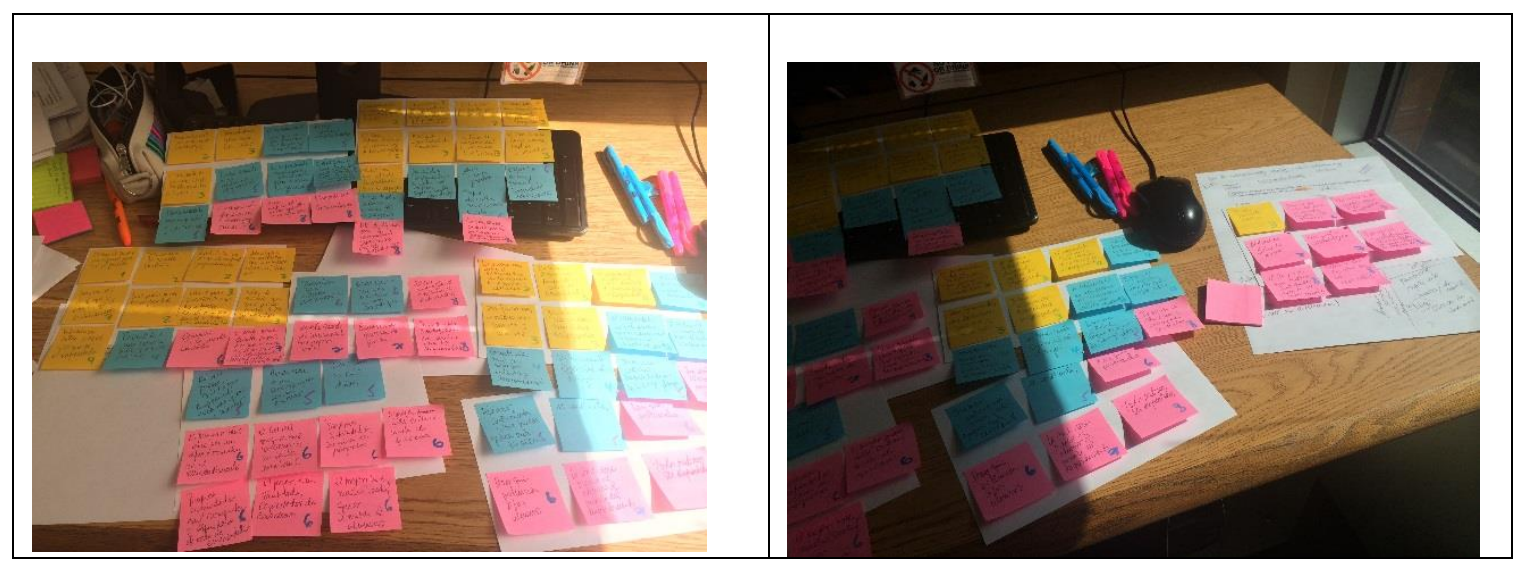

Figure 9. Photos of the process of manual coding determining basic and organizing themes from the interview transcripts.

Basic themes. I refined basic themes to reduce the data into a more manageable set of significant themes in order to assemble them into similar groupings. These basic themes are listed in the following Table 24 in which we can see a total of 27 basic themes across participants from the coding of interview transcripts. 
Table 24

\section{List of Basic Themes Across Participants}

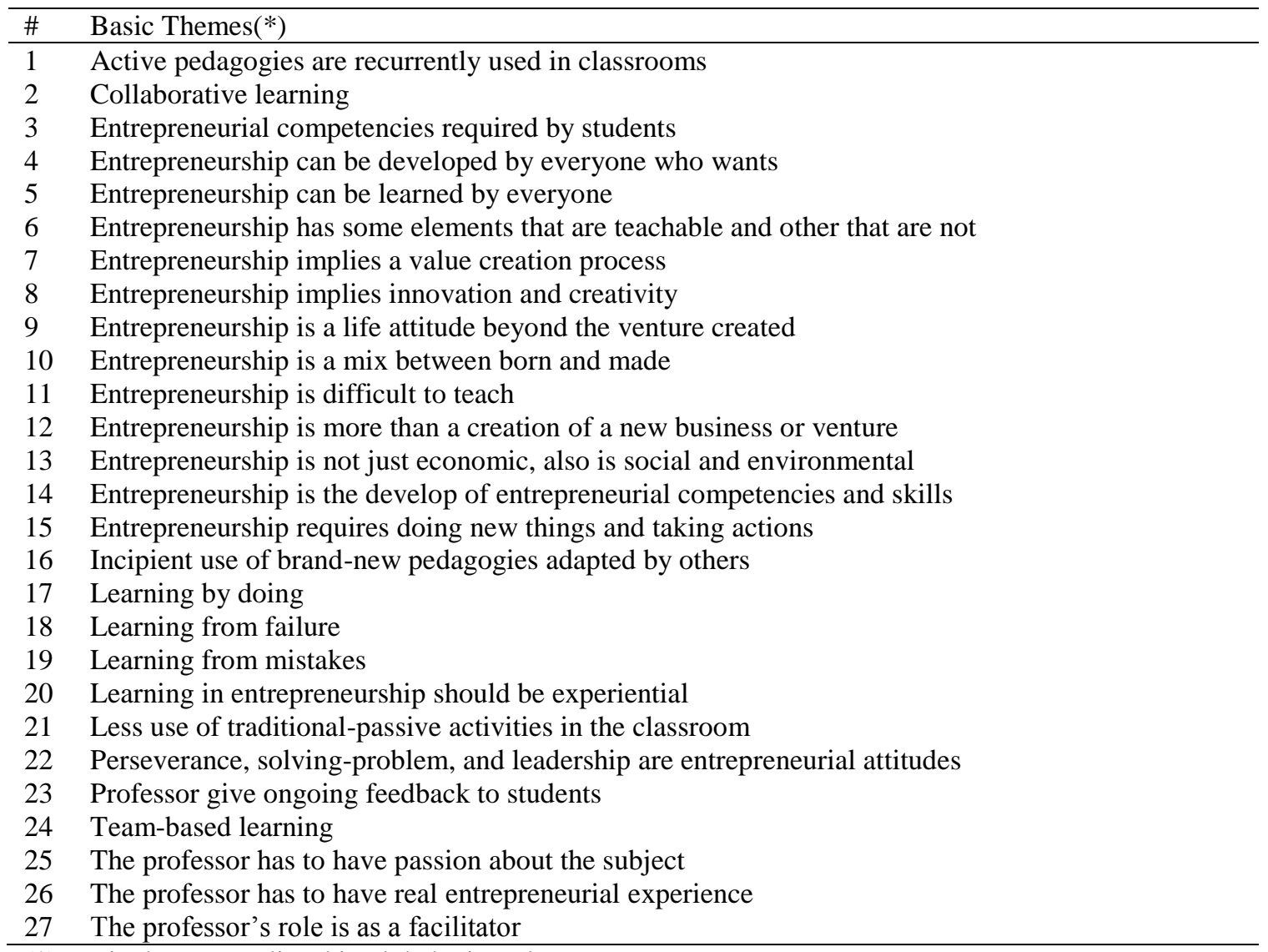

(*) Basic themes are listed in alphabetic order.

Organizing themes. From the list of basic themes across participants' interviews,

I grouped the themes that were common from the data in order creating clusters of basic

themes named organizing themes by Attride-Stirling (2001). According to the author,

from a practical point of view, an accurate number of organizing themes range from 4 to

15 as maximum to manage effectively the data and to construct the network in order to

respond to research questions. In the case of this study, I clustered the 27 basic themes

into 7 organizing themes, listed in following Table 25 . 
Table 25

\section{List of Organizing Themes Across Participants}

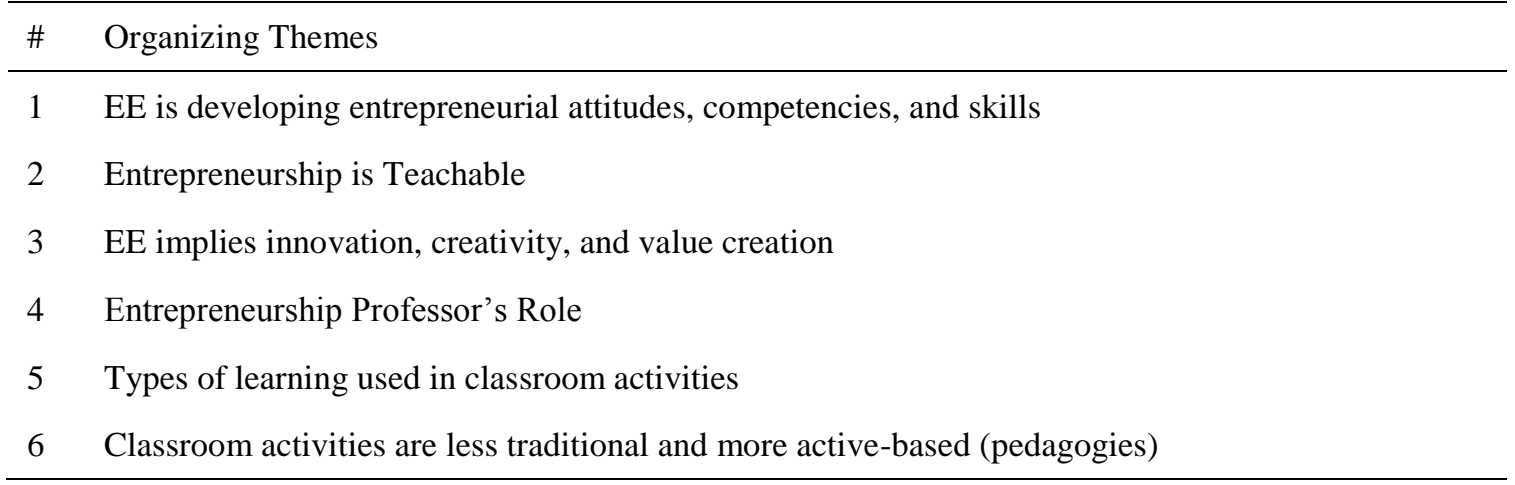

I created these organizing themes by the common topics between basic themes as well as considering the literature review on learning in entrepreneurship, teaching practices and pedagogies. In the next section, I present and describe in detail each of the seven organizing themes, providing reference to the specific quotes from participants that contained the basic themes as evidence from the interview transcripts.

\section{Theme 1: EE is developing an entrepreneurial attitudes, competencies, and}

skills. Table 26 contains the details of the basic themes were clustered to create the organizing theme of EE as developing of entrepreneurial attitudes, competencies, and skills. We can see in the Table that the first column contains the basic themes, the second column has the name of the participant who mentioned the theme as an example, and the final column shows the actual quote from the particular participant. 
Table 26

Evidence Supporting Entrepreneurial Attitude, Competencies, and Skills

\begin{tabular}{|c|c|c|}
\hline Basic Themes & $\begin{array}{l}\text { Participants } \\
\text { Quoted }\end{array}$ & Actual Quote \\
\hline \multirow[t]{3}{*}{$\begin{array}{l}\text { Entrepreneurship is a } \\
\text { life attitude beyond } \\
\text { the venture }\end{array}$} & Jenifer & $\begin{array}{l}\text { "entrepreneurial attitude is something much broader, in which } \\
\text { you can work on certain skills, like I said, teamwork, } \\
\text { leadership, communication, all this serves you for everything, } \\
\text { but not necessarily to create your company. So, I think those } \\
\text { are strong transferable skills for the development of our } \\
\text { students, as integral students" }\end{array}$ \\
\hline & Liliana & $\begin{array}{l}\text { "from the perspective of one who runs a venture indeed has to } \\
\text { do with attitudes, and has to do with attitudes that are not only } \\
\text { for business, but are for life in general, if you do not have that } \\
\text { for life overall, the truth is that it is extremely difficult to get a } \\
\text { project into a business, because perseverance is basic" }\end{array}$ \\
\hline & Manuel & $\begin{array}{l}\text { "entrepreneurship is actually the pursuit of happiness, and the } \\
\text { happiness you can search on any field of life and is becoming } \\
\text { more happy, true happiness, you're going to develop freely, } \\
\text { because you can be free as an employee and you can be an } \\
\text { intra-entrepreneur as an employee, and working individually" }\end{array}$ \\
\hline \multirow{2}{*}{$\begin{array}{l}\text { Entrepreneurship is } \\
\text { more than a creation } \\
\text { of a new business }\end{array}$} & Horacio & $\begin{array}{l}\text { "I feel that the social mobility is going to give to } \\
\text { entrepreneurship and education, not just one" }\end{array}$ \\
\hline & Ricardo & $\begin{array}{l}\text { "...entrepreneurship, say in the context of what is the form of } \\
\text { reasoning that an entrepreneur has?, how he/she thinks and } \\
\text { how it will be contacting for achieving these networking?, } \\
\text { finally, will enable him/her to create opportunities" }\end{array}$ \\
\hline \multirow[t]{2}{*}{$\begin{array}{l}\text { Development of } \\
\text { entrepreneurial } \\
\text { competencies }\end{array}$} & Jenifer & $\begin{array}{l}\text { "... we do not want them [students] all to be entrepreneurs, } \\
\text { but nevertheless if you develop these competencies, can foster } \\
\text { intra-entrepreneurs, then in this conviction that it motivates } \\
\text { me a little the subject of entrepreneurship. That if you develop } \\
\text { certain skills, the person will go well, regardless of whether } \\
\text { you think your company or not" }\end{array}$ \\
\hline & Liliana & $\begin{array}{l}\text { "I consider entrepreneurship as a competence model, that's } \\
\text { important, so therefore I always find the students made it clear } \\
\text { that there is a theoretical component, practical component and } \\
\text { an ethical component, and often taught them the issue of } \\
\text { value-creation to professionals especially in the ethical aspect, } \\
\text { that is, many make a difference" }\end{array}$ \\
\hline
\end{tabular}


Theme 2: Entrepreneurship is teachable. See Table 27.

Table 27

\section{Evidence Supporting Entrepreneurship is Teachable}

\begin{tabular}{|c|c|c|}
\hline Basic Themes & $\begin{array}{l}\text { Participants } \\
\text { Quoted }\end{array}$ & Actual Quote \\
\hline \multirow[t]{4}{*}{$\begin{array}{l}\text { Entrepreneurship } \\
\text { is difficult to } \\
\text { teach }\end{array}$} & Amanda & $\begin{array}{l}\text { "I think [EE] is difficult to teach, it is not easy to teach } \\
\text { entrepreneurship to today's students" ... but, I believe that you can } \\
\text { teach it, and clearly you cannot reach to the } 100 \% \text { but maybe you } \\
\text { can reach to the } 20 \% \text { per example" }\end{array}$ \\
\hline & Horacio & $\begin{array}{l}\text { "I believe that you can teach [EE], there is no way that you only } \\
\text { can be an entrepreneur since you are born...you can become an } \\
\text { entrepreneur fostering and developing entrepreneurial skills" }\end{array}$ \\
\hline & Katy & "definitely you can teach to become an entrepreneurial individual" \\
\hline & Ricardo & $\begin{array}{l}\text { "I think that entrepreneurship cannot be taught, but you can do is to } \\
\text { create an approach to the world of entrepreneurship to the students } \\
\text { and that clearly you can handle. The issue is how you approach } \\
\text { it...so it is in this context that one comes to [the] methodologies" }\end{array}$ \\
\hline \multirow{3}{*}{$\begin{array}{l}\text { Anyone can learn } \\
\text { how to be an } \\
\text { entrepreneurial } \\
\text { individual }\end{array}$} & Horacio & $\begin{array}{l}\text { "I believe that anyone can be an entrepreneur, it has shown me over } \\
\text { the years, from the students themselves, that people who are in a } \\
\text { totally different world, end up doing business" }\end{array}$ \\
\hline & Jenifer & $\begin{array}{l}\text { "That if you develop certain skills, the person is going to do well, } \\
\text { regardless of whether you think your company or not, the concept } \\
\text { of being an entrepreneur is a plus anyway" }\end{array}$ \\
\hline & Sergio & $\begin{array}{l}\text { "...I have the conviction, say, we can all be entrepreneurs, } \\
\text { everyone, absolutely everyone" }\end{array}$ \\
\hline \multirow[t]{2}{*}{$\begin{array}{l}\text { There are some } \\
\text { teachable } \\
\text { elements and } \\
\text { others that you } \\
\text { cannot teach }\end{array}$} & Katy & $\begin{array}{l}\text { "What I think is that there are some features certain people have } \\
\text { that there are so rooted in the attitudinal aspect, which cannot be } \\
\text { changed...but I believe that there is the option to change, and here } \\
\text { is when people take training" }\end{array}$ \\
\hline & Jennifer & $\begin{array}{l}\text { "another thing I also think it comes with the students and cannot } \\
\text { develop, is the subject of perseverance, that is, the person who is } \\
\text { already formed at that ... and to be an entrepreneur you have to be } \\
\text { persistent, you have to have tolerance for frustration, and that } \\
\text { neither can be taught, however, there are other things, } \\
\text { communication, planning, teamwork, leadership to some extent, } \\
\text { those you can form, but, however, I also ... we do not want all are } \\
\text { entrepreneurs, but nevertheless if you develop these skills, we can } \\
\text { foster intra-entrepreneurs, then in this conviction that it motivates } \\
\text { me a little the subject of entrepreneurship" }\end{array}$ \\
\hline \multirow{3}{*}{$\begin{array}{l}\text { The entrepreneur } \\
\text { is a mix between } \\
\text { born and made }\end{array}$} & Horacio & $\begin{array}{l}\text { "... as I said, if being a leader or leader is not, I think is not born, } \\
\text { there are the two" }\end{array}$ \\
\hline & Jenifer & $\begin{array}{l}\text { "I am convinced that the entrepreneur is a mix of born and made, I } \\
\text { think that there are things that have to be born with you, that cannot } \\
\text { be taught or developed, such as risk aversion. Some people are risk } \\
\text { averse and there are people who likes risk." }\end{array}$ \\
\hline & Sergio & $\begin{array}{l}\text { "Does the entrepreneur born, not made?, but I am radically } \\
\text { opposed to that, radically discouraged" }\end{array}$ \\
\hline
\end{tabular}


Theme 3: EE implies innovation, creativity and value creation. See Table 28.

Table 28

Evidence Supporting Entrepreneurship Implies Innovation, Creativity and Value Creation

\begin{tabular}{|c|c|c|}
\hline Basic Themes & $\begin{array}{l}\text { Participants } \\
\text { Quoted }\end{array}$ & Actual Quote \\
\hline \multirow{4}{*}{$\begin{array}{l}\text { Innovation and } \\
\text { creativity as content } \\
\text { or activities }\end{array}$} & Horacio & $\begin{array}{l}\text { "innovation, entrepreneurship and leadership are cornerstones, } \\
\text { that the College and the course have" }\end{array}$ \\
\hline & Katy & $\begin{array}{l}\text { "[the students] differentiate between innovation and } \\
\text { entrepreneurship and creativity" }\end{array}$ \\
\hline & Jenifer & $\begin{array}{l}\text { "... also we did some puzzles to develop a little creativity, it } \\
\text { was invented by a colleague, gave them the instruction to } \\
\text { write a poem, it had to do with entrepreneurship, they have to } \\
\text { give it a title, then as games to develop creativity" }\end{array}$ \\
\hline & Liliana & $\begin{array}{l}\text { "The program has aspects, as I said, creativity and innovation, } \\
\text { leadership issues, and project formulation. Sure, those are the } \\
\text { three areas" }\end{array}$ \\
\hline \multirow[t]{2}{*}{$\begin{array}{l}\text { Doing new things or } \\
\text { in an innovative } \\
\text { manner }\end{array}$} & Amanda & $\begin{array}{l}\text { "achieving students and empower them to be able also to } \\
\text { develop something new for them, then at the end of the } \\
\text { semester, develop a prototype, because in that ... one of the } \\
\text { demands that we did them, was to develop a prototype of the } \\
\text { idea they had planned, and initially an exhibition fair they had } \\
\text { to sell was made, but then evolved and now is an exhibition of } \\
\text { innovation" }\end{array}$ \\
\hline & Ricardo & $\begin{array}{l}\text { "innovation also have to do with new things, and the rest } \\
\text { maybe think you you're crazy, you're not realistic, etc., if you } \\
\text { find yourself in that situation, then, that way you're developing } \\
\text { what I call competencies" }\end{array}$ \\
\hline \multirow[t]{3}{*}{ Value Creation } & Manuel & $\begin{array}{l}\text { "I said students, do and create value, but the value is not } \\
\text { dollars, the value is not money, add value because they } \\
\text { build ... build relationships with people, because it builds } \\
\text { worlds, because through entrepreneurship makes networking } \\
\text { then I sack them and they change their chip" }\end{array}$ \\
\hline & Ricardo & $\begin{array}{l}\text { "... if they [students] approach to the entrepreneurial world } \\
\text { and see that the thing is in a certain way different from what } \\
\text { they thought, and that you are adding value" }\end{array}$ \\
\hline & Sergio & $\begin{array}{l}\text { "why not do the birthday party of something that lets value to } \\
\text { children?, who are the value propositions? I say that you have } \\
\text { to look always" }\end{array}$ \\
\hline
\end{tabular}


Theme 4. Entrepreneurship professor's role. See Table 29.

Table 29

\section{Evidence Supporting Entrepreneurship Professor's Role}

\begin{tabular}{|c|c|c|}
\hline Basic Themes & $\begin{array}{l}\text { Participants } \\
\text { Quoted }\end{array}$ & Actual Quote \\
\hline \multirow[t]{3}{*}{ Facilitator role } & Jenifer & $\begin{array}{l}\text { "the job of facilitator rather than being the center, that is, } \\
\text { because here the student is the center, and one is doing the } \\
\text { role of facilitator, versus being the center and everyone is } \\
\text { listening to you, and so on ... there are certain characteristics } \\
\text { that are relevant in order to have the teacher for this activity" }\end{array}$ \\
\hline & Manuel & $\begin{array}{l}\text { "facilitator and orchestrator, especially orchestrator of } \\
\text { emotions" }\end{array}$ \\
\hline & Sergio & $\begin{array}{l}\text { "... you have to be very atypical, as a teacher, I at most a } \\
\text { facilitator, important for students to drew their own } \\
\text { experiences, to write them, to describe them" } \\
\text { "The other is being "very constructive," i.e., starting with } \\
\text { experiences, then collect the opinions, process by the group, } \\
\text { that is, being a facilitator of what happens there" }\end{array}$ \\
\hline \multirow{2}{*}{$\begin{array}{l}\text { Professor gives } \\
\text { feedback to students } \\
\text { on an ongoing basis }\end{array}$} & Horacio & "[during class] it is a constant consulting, YES." \\
\hline & Manuel & $\begin{array}{l}\text { "then we first teach 'coaching' to students, not from the } \\
\text { ontological point of view, but we are always attentive to } \\
\text { supervise, guide, give feedback, show some possible ways, go } \\
\text { for it, so you choose the way you want, that entrepreneurship } \\
\text { is trying to do" }\end{array}$ \\
\hline \multirow{3}{*}{$\begin{array}{l}\text { Professor has to have } \\
\text { a real entrepreneurial } \\
\text { experience and } \\
\text { passion about } \\
\text { entrepreneurship }\end{array}$} & Amanda & $\begin{array}{l}\text { "The vast majority of teachers who teach entrepreneurship are } \\
\text { entrepreneurs themselves, then, we are in constant searching, } \\
\text { we are getting into training courses by our own" }\end{array}$ \\
\hline & Katy & $\begin{array}{l}\text { "The teacher who has this subject ... has to be closely linked } \\
\text { with the entrepreneurial environment too, I say weak point, } \\
\text { because if it is true I am involved, I have been involved with } \\
\text { many institutions, you do not have to lose that bond, must } \\
\text { remain updated, then that's where the job of staying current } \\
\text { with the institutions that support entrepreneurship and } \\
\text { entrepreneurs, then of course, when one begins to be fully } \\
\text { absorbed by the academy, that link is lost and you cannot miss } \\
\text { it, that's what matters" }\end{array}$ \\
\hline & Manuel & $\begin{array}{l}\text { "There is another factor that is important, is the person you } \\
\text { have in front of you who is going to teach, because the person } \\
\text { you have in front has to be passionate about entrepreneurship, } \\
\text { and otherwise is no good, honestly. There must be a person } \\
\text { who ... you can count on failure." }\end{array}$ \\
\hline
\end{tabular}


Theme 5: Types of learning used in classroom activities. See Table 30.

Table 30

\section{Evidence Supporting Types of Learning Used in Classroom Activities}

\begin{tabular}{|c|c|c|}
\hline Basic Themes & $\begin{array}{l}\text { Participants } \\
\text { Quoted }\end{array}$ & Actual Quote \\
\hline \multirow[t]{3}{*}{ Experiential Learning } & Katy & $\begin{array}{l}\text { "because guests speaker come to tell his/her story, the } \\
\text { experience and what I like the most is that the talks were } \\
\text { super-oriented, innovation, entrepreneurship, the innovative } \\
\text { environment, then they took the most important aspect from } \\
\text { the talk" }\end{array}$ \\
\hline & Liliana & $\begin{array}{l}\text { "to understand the difference between a satisfactory and a } \\
\text { necessity, I'm trying them to travel between their own lives, I } \\
\text { try to make this venture part of their life experience, for } \\
\text { example" }\end{array}$ \\
\hline & Sergio & $\begin{array}{l}\text { "is experiential learning, experiential, and this has a whole } \\
\text { logical sequence, I practice, that is, I do not do theory without } \\
\text { doing some practical exercise" }\end{array}$ \\
\hline \multirow[t]{3}{*}{ Learning by doing } & Amanda & $\begin{array}{l}\text { "... you know that in the end we learn by doing, however they } \\
\text { are kids or adults, we all like to get their hands in the dough } \\
\text { then entertain and see things in an entertaining way, and I find } \\
\text { it extremely pedagogically feasible, a little expensive, but as I } \\
\text { say, with few resources, just as with the students themselves } \\
\text { ask them if they want to do, it is quite good" }\end{array}$ \\
\hline & Horacio & $\begin{array}{l}\text { "With them [students] what we do, we do a lot of learning by } \\
\text { doing in the background ... I mean, they enter the course and } \\
\text { the first thing we must do is that day, the first class is to form } \\
\text { groups of students" }\end{array}$ \\
\hline & Rodrigo & $\begin{array}{l}\text { "they [students] are dedicated to making a case of an } \\
\text { entrepreneur who they have contacted, chosen, and has } \\
\text { accepted that the case be conducted on them" }\end{array}$ \\
\hline \multirow{2}{*}{$\begin{array}{l}\text { Collaborative } \\
\text { Learning/Team based } \\
\text { Learning }\end{array}$} & Katy & $\begin{array}{l}\text { "Team work is very important in this case. Like the lecture, } \\
\text { exercises and collaborative work." }\end{array}$ \\
\hline & Jenifer & $\begin{array}{l}\text { "Regarding methodology, well, there we use collaborative } \\
\text { learning after we did ... well students do not know how to } \\
\text { drew, but they had to create videos, creating videos on their } \\
\text { part, then the other issue that also works well, the work of } \\
\text { group in cases" }\end{array}$ \\
\hline \multirow[t]{2}{*}{$\begin{array}{l}\text { Learning from failure, } \\
\text { errors and mistakes }\end{array}$} & Amanda & $\begin{array}{l}\text { "... then you can see what a mistake they [students] can take } \\
\text { advantage, and learning, learning about them, never to make } \\
\text { that mistake" }\end{array}$ \\
\hline & Sergio & $\begin{array}{l}\text { "failure to me is something that is removed, is strikethrough, } \\
\text { say when speaking of failure, that is scratched, there is no } \\
\text { failure, there are experiences, then they [students] widely } \\
\text { practiced resilience and failure is a stage learning" }\end{array}$ \\
\hline
\end{tabular}


Theme 6: Classroom activities are less traditional and more active-based. See

Table 31.

Table 31

Evidence Supporting Classroom Activities: Less Traditional and More Active-Based

\begin{tabular}{|c|c|c|}
\hline Basic Themes & $\begin{array}{l}\text { Participant's } \\
\text { Quotes }\end{array}$ & Actual Quote \\
\hline \multirow[t]{4}{*}{$\begin{array}{l}\text { Less use of } \\
\text { traditional-passive } \\
\text { activities }\end{array}$} & Horacio & $\begin{array}{l}\text { "for instance, I used case studies, but all cases were what } \\
\text { Harvard [Business School] recommended, and that led us much } \\
\text { distance with the student, because they saw the impracticality in } \\
\text { Chile, even though they were very successful cases, Netflix, } \\
\text { Apple . . . etc., but I will not do that here in Chile . . I blame } \\
\text { that, it was like a little more structured, we wanted to do as } \\
\text { more academic the field, when the field has to be more } \\
\text { practical" }\end{array}$ \\
\hline & Liliana & $\begin{array}{l}\text { "I do not use the reading quiz or test, because actually I try to } \\
\text { generate the concept of entrepreneurship for life as an item in } \\
\text { the program" }\end{array}$ \\
\hline & Ricardo & $\begin{array}{l}\text { "there are just four lectures, classes are few, but there are more } \\
\text { development of cases, talks with entrepreneurs, talks of } \\
\text { CORFO" [Chilean public institution] }\end{array}$ \\
\hline & Manuel & $\begin{array}{l}\text { "[the students] make a presentation, we avoid long and tedious } \\
\text { reports, a very visual presentation covered the subject, where } \\
\text { they explain the process, to tell us [their] reflections on what } \\
\text { they learned, the hard..." }\end{array}$ \\
\hline \multirow[t]{3}{*}{$\begin{array}{l}\text { Active pedagogies } \\
\text { are more used }\end{array}$} & Katy & $\begin{array}{l}\text { "Students make a video in groups, they choose an entrepreneur } \\
\text { and make a video for the group. What is the purpose of the } \\
\text { video? The aim is not to learn to make videos unless the } \\
\text { purpose is to relate to entrepreneurs and then make them known } \\
\text { the entrepreneur in class." [filming videos/interview } \\
\text { entrepreneurs] }\end{array}$ \\
\hline & Liliana & $\begin{array}{l}\text { "I believe that aspects related to emotional intelligence, self- } \\
\text { confidence, teamwork, and everything that has to do with } \\
\text { creativity, which today is very important, and beyond that, I } \\
\text { would say, the subject of the research, because they [students] } \\
\text { are building autonomy, I think that here, to undertake, one of } \\
\text { the basic rules is the subject of autonomy" }\end{array}$ \\
\hline & Manuel & $\begin{array}{l}\text { "I believe that we cannot fall into abuse, especially early years } \\
\text { of education, like freshmen year, falling into the abuse of } \\
\text { writing papers, reading Harvard cases style, no!, you write it, } \\
\text { you write your entrepreneurial history as you go walking along } \\
\text { the race too, will go to strengthen this through life experiences } \\
\text { that you created, so is their hallmark, and that's extremely } \\
\text { important, learning by doing" }\end{array}$ \\
\hline
\end{tabular}


Table 31 (continued)

\begin{tabular}{|c|c|c|}
\hline Basic Themes & $\begin{array}{l}\text { Participant's } \\
\text { Quotes }\end{array}$ & Actual Quote \\
\hline & Sergio & $\begin{array}{l}\text { "... there's also a time of reflection, and to this gym I always } \\
\text { ask them to go with a blog [journal or dairy], and go and } \\
\text { writing down everything that passes them into the blog, what } \\
\text { they think, their reflections" }\end{array}$ \\
\hline \multirow[t]{3}{*}{$\begin{array}{l}\text { Other pedagogies/ } \\
\text { Incipient use of these } \\
\text { new pedagogies in } \\
\text { EE }\end{array}$} & Manuel & $\begin{array}{l}\text { "We have taken elements of 'design thinking,' a little of the } \\
\text { 'Lean start-up' as well. But I would say that there's nothing like } \\
100 \% \text { traced, this is an hybrid ... yes, it is a hybrid of different } \\
\text { methodologies, and we are not concerned so much, not even in } \\
\text { the syllabus, this comes from that side, no, but they built a } \\
\text { different approach" [Design Thinking } ® \text {, Lean Start-up] }\end{array}$ \\
\hline & Ricardo & $\begin{array}{l}\text { "Instead, my course is on the side of entrepreneurship, say in } \\
\text { the context of what is the form of reasoning that an entrepreneur } \\
\text { has? How she/he thinks, how she/he reasons, and how she/he } \\
\text { will achieve goals by contacting networks?, finally, they will } \\
\text { create opportunities. So our students have, what we call, a little } \\
\text { model of Sarasvathy" [Effectuation theory] }\end{array}$ \\
\hline & Sergio & $\begin{array}{l}\text { "... that would be my last update of what I'm doing, because } \\
\text { the 'enneagram' has given me a vision, which is: that all human } \\
\text { beings have their own characteristics, that differentiate them } \\
\text { from others such as the fingerprint, and we all can develop } \\
\text { healthily within the area in which we move us more easily, and } \\
\text { in all of these areas you can do entrepreneurship, innovation } \\
\text { and leadership, either. Well, and the enneagram describes nine } \\
\text { basic features, because they are basic, being mixed with each } \\
\text { other, but it's good to have them clear" [Enneagram] }\end{array}$ \\
\hline
\end{tabular}

\section{Analysis of the Pedagogies}

In addition to the analysis and coding of interview transcripts as a whole, in the case of the pedagogies and classroom activities, I also looked again through the responses to questions 3 to 6 in the interview protocol (see Table 32) to find evidence of the use of the pedagogies by each faculty. 
Table 32

Interview Protocol for Entrepreneurship Faculty

Q3: What are the specific pedagogies that you currently use in your classes?

Q4: What influenced you to select the pedagogies that you are using in your classes now?

Q5: What do you like the most about the pedagogies from your current syllabus/current class?

Q6: Tell me more about the experience of implementing those pedagogies with students.

It is important to note that the main criteria in this analysis was to go through the interview transcripts to see if any faculty mentioned a specific pedagogy or activity in the classroom as well as whether that pedagogy was used by the faculty in their classroom. I developed an initial code frame that drew upon from the literature review regarding different types of pedagogies used in entrepreneurship classrooms, presented in chapter 2. Researchers point out that there are two main groups of entrepreneurial pedagogies: traditional or passive versus innovative or active pedagogies (Mwaslawiba, 2010; Fayolle, 2013).

I then used this coding frame to look at the transcripts first by participant and then across participants. Results of this analysis are presented in Tables 34 to 36 . Each table shows the type of the pedagogy mentioned by the faculty. The criteria to select and check it from the interview transcripts were: (a) if the pedagogy was mentioned by the faculty and (b) if that pedagogy was used in the classroom activity.

Table 33 shows the results of the five different type of traditional pedagogies selected from the literature review. As we can observe in the table, just three out of five types of traditional pedagogies were mentioned by some of the faculty. The most common activity used is the business plan creation as written report. They do not mention 
the use of group discussion in class or individual presentation because these oral presentation usually are in groups. In fact, from these results, we can see that the majority of the faculty do not mention or use these type of pedagogies.

Table 33

Traditional or Passive Pedagogies in EE per Faculty

\begin{tabular}{|l|c|c|c|c|c|c|c|c|c|}
\hline $\begin{array}{l}\text { Type of } \\
\text { Traditional } \\
\text { or Passive } \\
\text { Pedagogy(*) }\end{array}$ & Amanda & Horacio & Katy & Jenifer & Liliana & Manuel & Ricardo & Sergio & $\begin{array}{c}\text { Total per } \\
\text { pedagogy }\end{array}$ \\
\hline $\begin{array}{l}\text { Business } \\
\text { Plan creation } \\
\text { (written } \\
\text { report) }\end{array}$ & $\mathrm{x}$ & & $\mathrm{x}$ & $\mathrm{x}$ & $\mathrm{x}$ & & $\mathrm{x}$ & & $5 / 8$ \\
\hline Case studies & & & $\mathrm{x}$ & $\mathrm{x}$ & & $\mathrm{x}$ & $\mathrm{x}$ & & $4 / 8$ \\
\hline $\begin{array}{l}\text { Group } \\
\text { discussion }\end{array}$ & & & & & & & & & $0 / 8$ \\
\hline $\begin{array}{l}\text { Individual } \\
\text { presentations }\end{array}$ & & & $\mathrm{x}$ & $\mathrm{x}$ & & & $\mathrm{x}$ & & $3 / 8$ \\
\hline Lecture & & & & & & & & & \\
\hline $\begin{array}{l}\text { Total by } \\
\text { faculty }\end{array}$ & $1 / 5$ & $0 / 5$ & $3 / 5$ & $3 / 5$ & $1 / 5$ & $1 / 5$ & $3 / 5$ & $0 / 5$ & \\
\hline
\end{tabular}

(*) Adapted from Mwaslawiba (2010) and Fayolle (2013) and listed in alphabetical order.

The following Table 34 shows the 12 different types of active-based pedagogies or classroom activities mentioned and used by faculty according to the transcripts interviews. As we can observe in the Table 34, the most-mentioned active-based pedagogy is the pedagogy of team work or group dynamic in classroom because as reported by faculty. 
Table 34

Active-Based Pedagogies Research Based in EE per Faculty

\begin{tabular}{|c|c|c|c|c|c|c|c|c|c|}
\hline Type of Active Pedagogy & 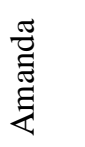 & $\begin{array}{l}\stackrel{0}{0} \\
\frac{\pi}{0} \\
\text { 足 }\end{array}$ & 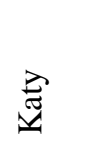 & 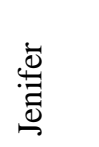 & $\stackrel{\stackrel{\Xi}{\Xi}}{: ~}$ & $\begin{array}{l}\bar{\Xi} \\
\stackrel{\Xi}{\Xi} \\
\stackrel{\Sigma}{\Sigma}\end{array}$ & 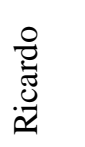 & $\begin{array}{l}. \frac{9}{00} \\
\vec{b} \\
\qquad\end{array}$ & 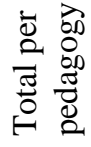 \\
\hline $\begin{array}{l}\text { Business Plan simulation } \\
\text { (with prototype) }\end{array}$ & $\mathrm{x}$ & & $\mathrm{x}$ & $\mathrm{x}$ & $\mathrm{x}$ & & & $\mathrm{x}$ & $5 / 8$ \\
\hline Canvas Model & $\mathrm{x}$ & $\mathrm{x}$ & $\mathrm{x}$ & $\mathrm{x}$ & & & & & $4 / 8$ \\
\hline Field Trips & $\mathrm{x}$ & & & & & & & & $1 / 8$ \\
\hline Games & & & $\mathrm{x}$ & $\mathrm{x}$ & & & & & $2 / 8$ \\
\hline Guest speakers & & & $\mathrm{x}$ & $\mathrm{x}$ & & & $\mathrm{x}$ & $\mathrm{x}$ & $4 / 8$ \\
\hline Interviews & & & & & & & $\mathrm{x}$ & $\mathrm{x}$ & $2 / 8$ \\
\hline $\begin{array}{l}\text { Personal Essays (written } \\
\text { reports) }\end{array}$ & & & $\mathrm{x}$ & $\mathrm{x}$ & & & $\mathrm{x}$ & $\mathrm{x}$ & $4 / 8$ \\
\hline $\begin{array}{l}\text { Setting real small business } \\
\text { ventures }\end{array}$ & & $\mathrm{x}$ & & & & $\mathrm{x}$ & & & $2 / 8$ \\
\hline $\begin{array}{l}\text { Team work or group } \\
\text { dynamic }\end{array}$ & $\mathrm{x}$ & $\mathrm{x}$ & $\mathrm{x}$ & $\mathrm{x}$ & $\mathrm{x}$ & $\mathrm{x}$ & $\mathrm{x}$ & $\mathrm{x}$ & $8 / 8$ \\
\hline Use videos in class & $\mathrm{x}$ & & $\mathrm{x}$ & & $\mathrm{x}$ & & & & $3 / 8$ \\
\hline $\begin{array}{l}\text { Video recording or filming } \\
\text { by students }\end{array}$ & & $\mathrm{x}$ & $\mathrm{x}$ & $\mathrm{x}$ & & $\mathrm{x}$ & & & $4 / 8$ \\
\hline Workshops or Seminars & & & $\mathrm{x}$ & $\mathrm{x}$ & & & $\mathrm{x}$ & & $3 / 8$ \\
\hline Total by faculty & $5 / 12$ & $4 / 12$ & $9 / 12$ & $8 / 12$ & $3 / 12$ & $3 / 12$ & $5 / 12$ & $5 / 12$ & \\
\hline
\end{tabular}

(*) Adapted from Mwaslawiba (2010) and Fayolle (2013) and listed in alphabetical order.

The business plan pedagogy is also one of the most reported and used by faculty, either as the traditional type of written report or the type of business plan simulated using a prototype. Guest speakers and filming videos of entrepreneurs' interviews by students are the third type of pedagogy more mentioned by faculty. The least used pedagogies in this categories are field trips (mentioned only in one case) due to the expensive of organization and implementation. 
Regarding results by faculty, just two of the participants (Katy and Jenifer) mentioned using different types of active-base pedagogies. In both cases, more than $50 \%$ of the total of pedagogies, 9 out of 12 and 8 out of 12 respectively. In sum, faculty are using a mix of activities in classroom; they do not use just one type. Comparing results from Tables 33 and 34, it appears that faculty are using more of the active-based pedagogies.

In Table 35, I grouped all of the pedagogies that were out of the frame of the initial coding used in this analysis and that were mentioned by faculty. I called these "other pedagogies" because even though some of them are mentioned in the literature review on pedagogies in entrepreneurship, they are relatively new for the field of the EE. Although some of these other pedagogies become increasingly attractive for some of the faculty, they have not yet been sufficiently recognized and discussed in the context of entrepreneurship and especially not in the context of EE (Von Kortzfleisch, Zerwas, \& Mokanis, 2013).

In summary, from this coding analysis of the pedagogies from interview transcripts, I can conclude that the most frequently used pedagogies mentioned by faculty are those that are identified in the literature as active-based activities, because they required active and vibrant participation from the students. From the total of 31 pedagogies listed in the coding frame, 5 are traditional or passive representing $16 \% ; 12$ are from the active-based categories representing $39 \%$ of the total; and other pedagogies total 14 , representing $45 \%$ of the total of 31 . 
Table 35

Other Pedagogies That Appear From the Analysis of the Qualitative Data

\begin{tabular}{|c|c|c|c|c|c|c|c|c|c|}
\hline Other Pedagogies & 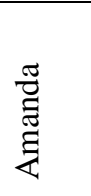 & 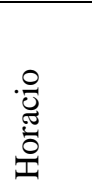 & 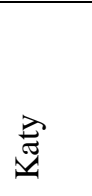 & 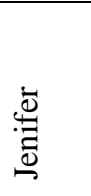 & 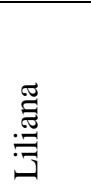 & 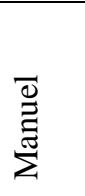 & 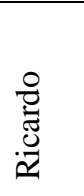 & $\begin{array}{l}\frac{0}{0} \\
\dot{0} \\
\omega\end{array}$ & 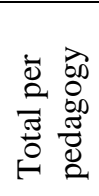 \\
\hline $\begin{array}{l}\text { Art and Music in } \\
\text { classroom }\end{array}$ & & & & & & & & $\mathrm{x}$ & $1 / 8$ \\
\hline Brainstorming & $\mathrm{x}$ & & & & & & & & $1 / 8$ \\
\hline Clickers (Tecleras) & & & $\mathrm{x}$ & $\mathrm{x}$ & & & & & $2 / 8$ \\
\hline Coaching to students & & & & & & $\mathrm{x}$ & & $\mathrm{x}$ & $2 / 8$ \\
\hline $\begin{array}{l}\text { Design Thinking }{ }^{\circledR} \\
\text { (elements of) }\end{array}$ & $\mathrm{x}$ & $\mathrm{x}$ & & & & $\mathrm{x}$ & & & $3 / 8$ \\
\hline Effectual Thinking & & & & & & & $\mathrm{x}$ & & $1 / 8$ \\
\hline Elevator Pitch & $\mathrm{x}$ & $\mathrm{x}$ & $\mathrm{x}$ & & & $\mathrm{x}$ & & & $4 / 8$ \\
\hline Enneagram & $\mathrm{x}$ & & & & & & & $\mathrm{x}$ & $2 / 8$ \\
\hline Entrepreneurial Fair & & $\mathrm{x}$ & & & $\mathrm{x}$ & $\mathrm{x}$ & & & $3 / 8$ \\
\hline Feedback to students & & $\mathrm{x}$ & & & $\mathrm{x}$ & $\mathrm{x}$ & & $\mathrm{x}$ & $4 / 8$ \\
\hline Keep a journal & & & & & & & & $\mathrm{x}$ & $1 / 8$ \\
\hline Observations & & & & & & & & $\mathrm{x}$ & $1 / 8$ \\
\hline Poems & & & $\mathrm{x}$ & $\mathrm{x}$ & & & & & $2 / 8$ \\
\hline $\begin{array}{l}\text { SWOT matrix } \\
\text { (strengths, weak-nesses, } \\
\text { opportunities and } \\
\text { threats) }\end{array}$ & $\mathrm{x}$ & & & & & $\mathrm{x}$ & & $\mathrm{x}$ & $3 / 8$ \\
\hline Total by faculty & $5 / 14$ & $5 / 14$ & $3 / 14$ & $2 / 14$ & $2 / 14$ & $6 / 14$ & $1 / 14$ & $7 / 14$ & \\
\hline
\end{tabular}

(*) Extracted from the coding analysis of the transcripts interview and listed in alphabetical order.

Figure 10 shows a graphic representation of the overall use of each type of pedagogy across participants. The active-based pedagogies were the most mentioned and used (49\%). Other pedagogies were $37 \%$ of those used or mentioned by faculty in their interviews. These types of other pedagogies are new or recent and their use is emerging 
in the field (Neck \& Greene, 2011). Traditional pedagogies are the least used (14\%) and this is in concordance with the analysis of the thematic network, in which various faculty mentioned that they are using those type of pedagogies less than before.

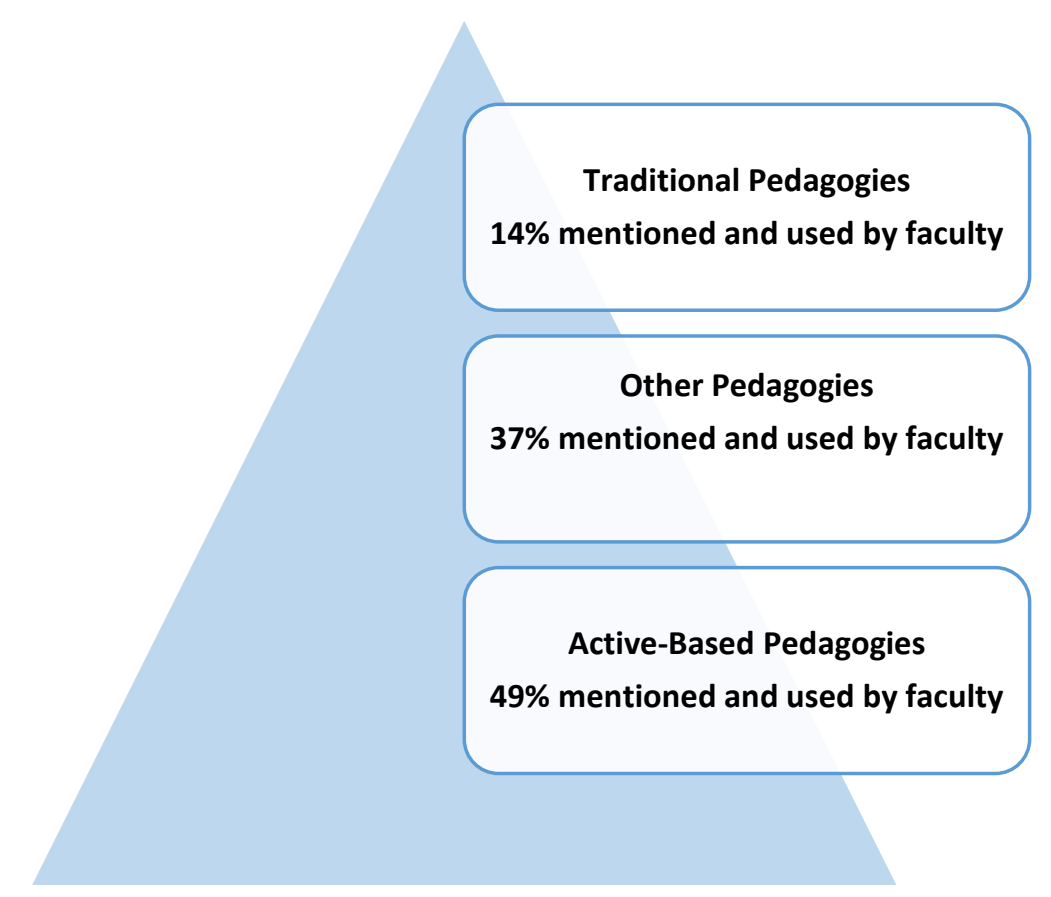

Figure 10. Relationship between types of pedagogies used by faculty.

Table 36 shows the use of pedagogies by each of the faculty participants. When I tabulated this information by each of the faculty participants, I realized that none of the eight faculty participants have the traditional type as the most used. They mostly used active-based pedagogies and/or new pedagogies. Faculty are divided between those who use more active-base or other pedagogies. Therefore, these results are similar to the information that I extracted from the basic thematic network analysis. Faculty are using more active-based and innovative pedagogies in their classrooms. 
Table 36

Use of Pedagogies by Faculty, Classified as Traditional, Active-Based, and Other

\begin{tabular}{lllccc}
\hline & $\begin{array}{c}\text { Name+ } \\
(\text { Age })\end{array}$ & $\begin{array}{c}\text { Entrepreneurial } \\
\text { experience }\end{array}$ & $\begin{array}{c}\text { Traditional } \\
\text { Pedagogies (\%) }\end{array}$ & $\begin{array}{c}\text { Active-Based } \\
\text { Pedagogies } \\
(\%)\end{array}$ & $\begin{array}{c}\text { Other } \\
\text { Pedagogies } \\
(\%)\end{array}$ \\
\hline 1 & $\begin{array}{l}\text { Amanda } \\
(34)\end{array}$ & Entrepreneur & $9 \%$ & $\mathbf{4 5 \%}$ & $\mathbf{4 5 \%}$ \\
2 & $\begin{array}{l}\text { Horacio } \\
(27)\end{array}$ & Entrepreneur & $0 \%$ & $44 \%$ & $\mathbf{5 6 \%}$ \\
3 & $\begin{array}{l}\text { Katy } \\
(39)\end{array}$ & Entrepreneur & $20 \%$ & $\mathbf{6 0 \%}$ & $20 \%$ \\
4 & $\begin{array}{l}\text { Jenifer } \\
(46)\end{array}$ & $\begin{array}{l}\text { Academic \& } \\
\text { Consultant }\end{array}$ & $23 \%$ & $\mathbf{6 2 \%}$ & $15 \%$ \\
5 & $\begin{array}{l}\text { Liliana } \\
(38)\end{array}$ & Entrepreneur & $17 \%$ & $\mathbf{5 0 \%}$ & $33 \%$ \\
6 & $\begin{array}{l}\text { Manuel } \\
(38)\end{array}$ & Entrepreneur & $10 \%$ & $30 \%$ & $\mathbf{6 0 \%}$ \\
7 & $\begin{array}{l}\text { Ricardo } \\
(57)\end{array}$ & Academic \& & & & \\
8 & $\begin{array}{l}\text { Consultant } \\
\text { Sergio } \\
(73)\end{array}$ & Entrepreneur & $33 \%$ & $\mathbf{5 6 \%}$ & $11 \%$ \\
\hline
\end{tabular}

(+) Entrepreneurship faculty names are pseudonyms to keep their anonymity in this study.

\section{Analysis of Syllabi as Artifacts}

As I mentioned in chapter 3, another data source collected and analyzed during Phase II (QUAL) was the syllabi from the faculty interviewed. Each syllabus was read in order to find evidence of the content, learning goals, and pedagogical practices of each entrepreneurship course as well as to contrast the information provided by the faculty during the interview about entrepreneurial learning goals. A structural coding method based on Saldana (2009) was used to code the text from syllabi. For the list of codes, I used the typology of EE based on the work of Pittaway and Edwards (2012) because it 
explains in detail what is meant by learning about, for and through EE and also it is related with the literature.

The six syllabi collected all contained some elements of the type of learning "for" entrepreneurship. Just one out of the six syllabi had elements of the type of learning about entrepreneurship, specifically regarding raising awareness about the EP and the entrepreneurial ecosystem. However, this course's syllabi also encouraged students to develop a business plan in a simulated context (see Table 37).

Regarding the third type of learning in EE (learning through entrepreneurship), just three out of the six syllabi mention the learning outcomes related to this form of EE. In those syllabi, I found expressions such as "students must learn how to develop key relationships and networking with stakeholders" and "students have to run real companies" or "students gets close to the lived experience of the entrepreneurs through the creation or videos about a real entrepreneur."

In sum, I extracted from the written narrative of the syllabi from each faculty interviewed and found that the majority of entrepreneurship courses from this sample are developing the type of EE that is similar to learning for entrepreneurship (Gibb, 2002) in which entrepreneurship is a process of developing competencies, skills and abilities for students to become entrepreneurs. From the analysis of the syllabus, even though the classes on entrepreneurship are different titles and names, the majority of them focus on preparing students to create business plans or becoming an entrepreneur. 
Table 37

Syllabus Analysis and Results. Based on Frame From Pittaway and Edwards (2012).

\begin{tabular}{|c|c|c|}
\hline $\begin{array}{l}\text { Title of the } \\
\text { course based on } \\
\text { syllabus }\end{array}$ & Principle form of EE & Type of learning outcome found in the syllabus \\
\hline $\begin{array}{l}\text { Entrepreneurial } \\
\text { and Innovative } \\
\text { skill } \\
\text { development } \\
\text { workshop }\end{array}$ & $\begin{array}{l}\text { Majority of the text } \\
\text { mention or related } \\
\text { with learning "for" } \\
\text { entrepreneurship } \\
\text { However there are a } \\
\text { few elements related } \\
\text { to learning "through" } \\
\text { entrepreneurship }\end{array}$ & $\begin{array}{l}\text { Entrepreneurial behavior, attitude and skill development. } \\
\text { Students gain generic entrepreneurship competencies } \\
\text { associated with entrepreneurship. } \\
\text { Learning how to develop key relationships through practice } \\
\text { with stakeholders and peers. }\end{array}$ \\
\hline $\begin{array}{l}\text { Business Plan } \\
\text { Creation }\end{array}$ & $\begin{array}{l}\text { Learning "for" } \\
\text { entrepreneurship }\end{array}$ & $\begin{array}{l}\text { Students gain generic entrepreneurship competencies } \\
\text { associated with entrepreneurship. } \\
\text { Engage students in tasks, activities, projects that enable } \\
\text { them to acquire skills and competencies through business } \\
\text { planning simulations. }\end{array}$ \\
\hline $\begin{array}{l}\text { Entrepreneurial } \\
\text { Attitude } \\
\text { Development }\end{array}$ & $\begin{array}{l}\text { Learning "about" } \\
\text { entrepreneurship } \\
\text { However there are a } \\
\text { few elements related } \\
\text { to learning "for" } \\
\text { entrepreneurship }\end{array}$ & $\begin{array}{l}\text { Key minimum business knowledge of the start-up process } \\
\text { and other entrepreneurial contexts. } \\
\text { To raise awareness about entrepreneurship and } \\
\text { entrepreneurial ecosystem. } \\
\text { Understanding the process of business entry and stages of } \\
\text { setting up an organization through business planning } \\
\text { simulations. }\end{array}$ \\
\hline $\begin{array}{l}\text { Entrepreneurial } \\
\text { Spirit }\end{array}$ & $\begin{array}{l}\text { Learning “for" } \\
\text { entrepreneurship }\end{array}$ & $\begin{array}{l}\text { Entrepreneurial behavior, attitude and skill development. } \\
\text { Students gain generic entrepreneurship competencies } \\
\text { associated with entrepreneurship. }\end{array}$ \\
\hline $\begin{array}{l}\text { Entrepreneurial } \\
\text { Initiative }\end{array}$ & $\begin{array}{l}\text { Learning "for" } \\
\text { entrepreneurship } \\
\text { However there are } \\
\text { some a elements } \\
\text { related to learning } \\
\text { "through" } \\
\text { entrepreneurship }\end{array}$ & $\begin{array}{l}\text { Entrepreneurial behavior, attitude and skill development. } \\
\text { Students gain generic entrepreneurship competencies } \\
\text { associated with entrepreneurship. } \\
\text { Engage students in activities that enable them to get close to } \\
\text { the lived experiences of entrepreneurs }\end{array}$ \\
\hline $\begin{array}{l}\text { Entrepreneurship } \\
\text { Workshop }\end{array}$ & $\begin{array}{l}\text { Learning "for" } \\
\text { entrepreneurship } \\
\text { However there are a } \\
\text { few elements related } \\
\text { to learning "through" } \\
\text { entrepreneurship }\end{array}$ & $\begin{array}{l}\text { Entrepreneurial behavior, attitude and skill development. } \\
\text { Students gain generic entrepreneurship competencies } \\
\text { associated with entrepreneurship. } \\
\text { Engage students in activities that enable them to get close to } \\
\text { the lived experiences of entrepreneurs and in "real" } \\
\text { projects. }\end{array}$ \\
\hline
\end{tabular}




\section{Summary of the Primary Findings in Phase II (QUAL)}

The different data sources in this qualitative Phase-interview transcripts, analysis of the pedagogies used in classrooms, and the syllabi analysis- helped me to extract from data a total of 27 basic themes, which were grouped into 6 organizing themes as well as to develop the global themes to create the final thematic network. Then, I summarize all these qualitative data and produce a thematic network for each global theme revealed by the analysis. Global themes are macro topics that make sense and represent an argument about a given issue; in this case, issues related with the research questions of this study: EE and entrepreneurship teaching.

The final objective was to summarize the themes in order to illustrate them in a non-hierarchical and web-like representation (Attride-Stirling, 2001). Figure 11 shows the first attempt to develop a thematic network relating themes regarding EE and its distinct characteristics. 


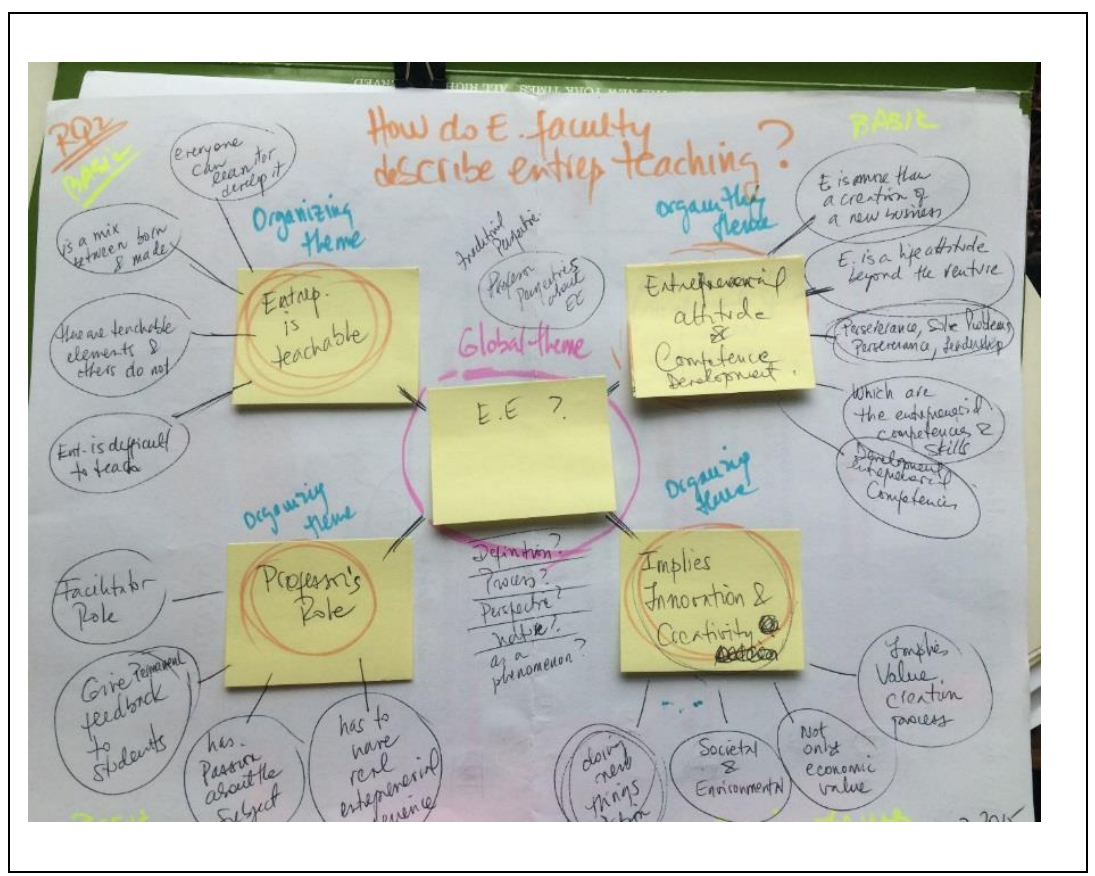

Figure 11. First sketch of the thematic network for the issue of EE.

Using the thematic network as a tool to analyze these qualitative data, I elaborated the thematic network that summarizes the analysis of qualitative data about EE (see Figure 12).

Regarding the topic of entrepreneurship teaching, I produced this thematic network that summarizes the organizing themes: types of learning used in classroom activities and the type of pedagogies used by faculty in their activities with students. I identified "teaching is the organization of students' activities" as a global theme in EE (see Figure 13). 


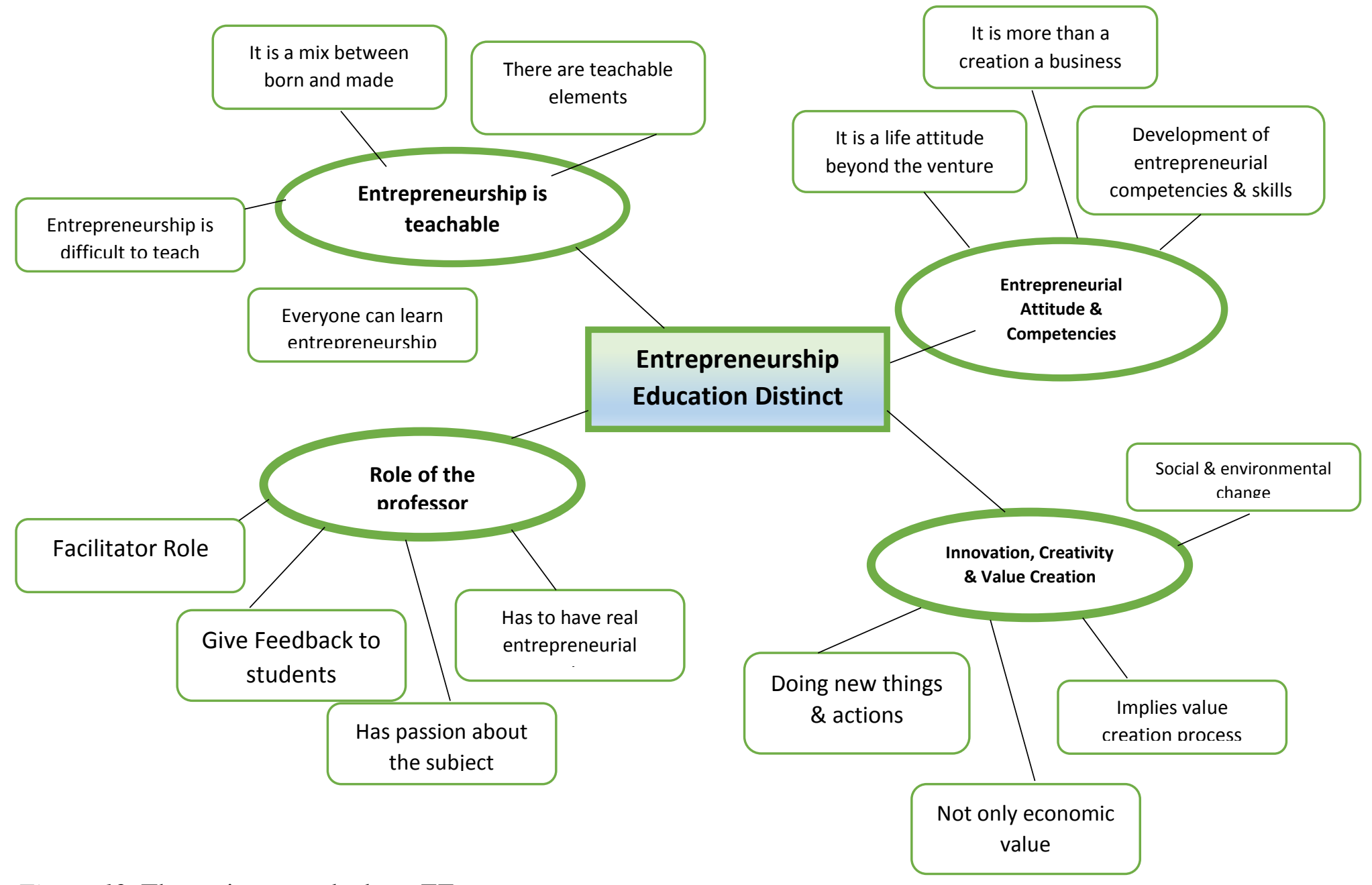

Figure 12. Thematic network about EE. 


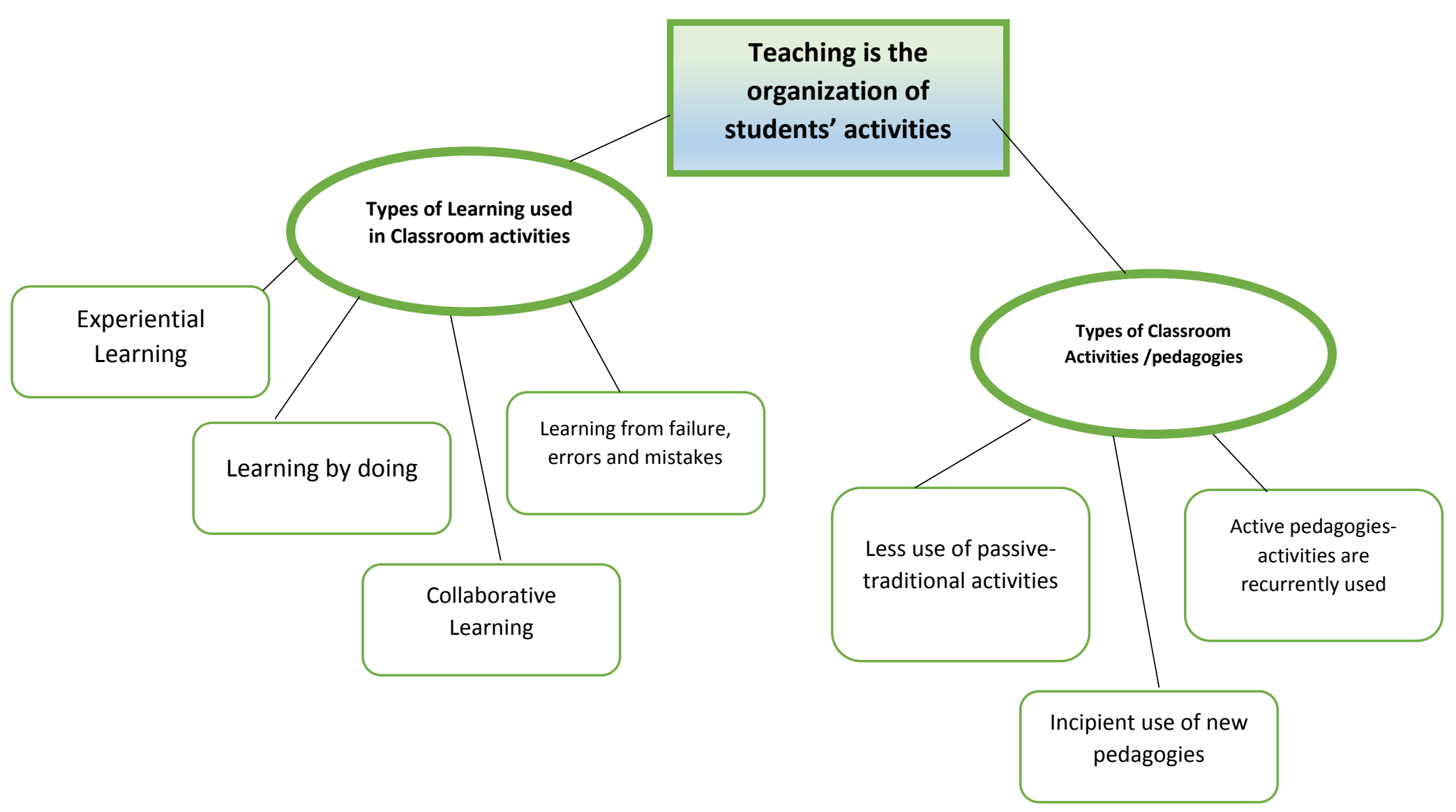

Figure 13. Thematic network about entrepreneurship teaching. 
Finally, during the process of creation and revision of the thematic network created, I identified a global theme that connects the networks created (see Figure 14). In fact, considering the information from the analysis of the syllabi, I wanted to find a global theme that connected the other two global themes about the characteristics of EE and entrepreneurship teaching. The final global theme is "learning for entrepreneurship," because this is the type of EE that most faculty mentioned they are developing in their classes and which was also shown in the syllabi as other sources of data.

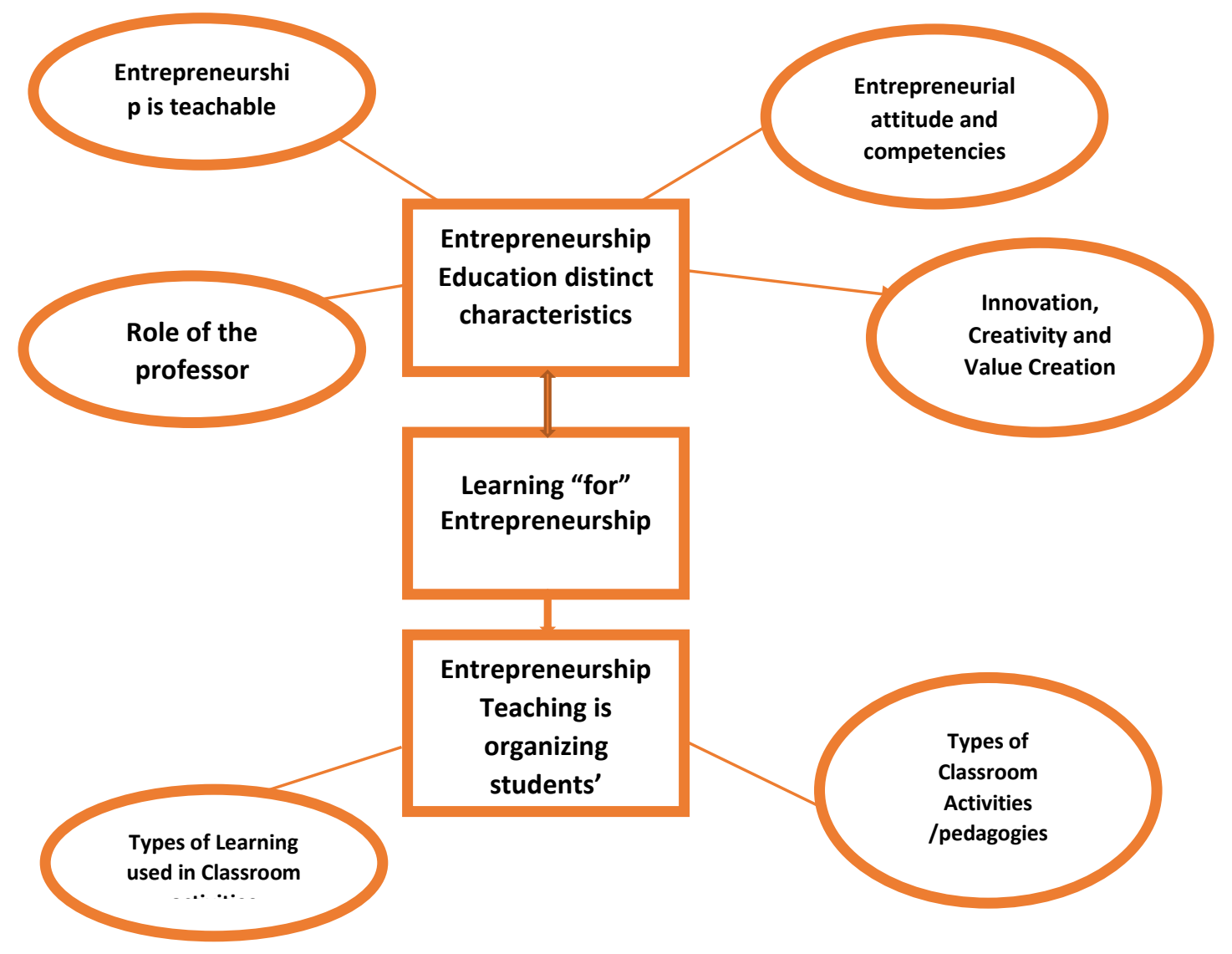

Figure 14. Final thematic network clustering organizing and global themes. 


\section{Limitations of the Study}

While there are interesting results and findings within this study, it would be remiss not to mention some limitations. I have identifies three limitations of my study. The first one is related to the instruments used to measure the entrepreneurial intention in the case of students and teaching perspectives in the case of faculty. Both instruments, student and faculty surveys, were self-reported and were accessed through an online platform. Some researchers claimed that self-reporting instruments hold some problems. For this reason, I also gathered qualitative data to corroborate self-reported quantitative data.

The second limitation regards the fact that I did not observe what is happening inside the classroom while taking to the faculty about the use of different pedagogies. I did not consider the observation of the student interaction in the entrepreneurship classroom. I used secondary data from online survey on students and faculty that were collected by a previous study, as I mentioned in chapter 3 . In addition, my study lacks the students' point of view in that no students were interviewed in this study. The lack of representation of students' voices could be addressed through further research.

The third limitation relates to the sample size $(n=270)$ in conducting statistical analyses during Phase I of my study. According to Krathwohl (2009), larger sample sizes are preferable because the standard error decreases and makes it easier to generalize results. The results and the lack of statistical significance did not allow me to select faculty for the subsample $(n=18)$ that have a high impact on the student entrepreneurial intentions. However, as stated in chapter 3, the intention of my study was not to 
generalize results, but rather to follow Morgan's (2007) and Creswell's (2014b) notion of transferability of results and findings to guide and inform other researchers looking for similar research designs and procedures.

\section{Summary}

In this chapter 4, I presented data collected and analyzed from both chronological Phases (quan $\rightarrow$ QUAL) in this study. First, I presented quantitative data results from Phase I that helped me to analyze variables such as the student entrepreneurial intention and teaching experience regarding entrepreneurship as well as to relate the student entrepreneurial intentions to the teaching perspective profile by faculty. All of the statistical analyses helped me to respond to research question 1.

Second, I presented the interpretation of the data result from qualitative Phase II to convey specific findings associated with the purpose of my study and research questions 2 to 5 using the step-by-step of thematic network analysis (Attride-Stirling, 2001). Finally, I presented a synthesis of results and findings by each of the two consecutive Phases I and II of my study that follows a MMR type of research. This chapter ends with the description of the limitations of my study.

Chapter 5 presents a discussion of each research question in my study, summarizing the findings and including implications for different stakeholders in EE as well as indications for further research. 


\section{CHAPTER 5}

\section{DISCUSSION AND IMPLICATIONS}

\section{Introduction}

Chapter 5 discusses the results and findings from this mixed methods study and presents major implications for EE and teaching practices. First, I synthesize results from chapter 4 and discuss each of the five research questions. Second, I consider what the research indicates about the theoretical and conceptual frameworks from chapter 2. Next, I discuss the implications for practice and present recommendations for future research. Lastly, I share my final thoughts and present a brief summary of chapter 5.

\section{Purpose of the Study and Research Questions}

The purpose of this study was twofold. First, I examined the relationship between faculty teaching perspectives/experiences, and student entrepreneurial intentions in required entrepreneurship courses at Chilean universities (Phase I: quantitative, secondary data). The purpose of this examination was to identify faculty who seem to have the greatest impact on students' entrepreneurial intentions. However, because of the lack of a statistical relationship between faculty teaching perspectives/experiences and student intentions found in the secondary data set during Phase I, I was unable to identify the faculty with the greatest impact on student intentions. From all the students from the secondary data set who had both pre and post scores on the entrepreneurial intention items $(n=270)$, I identified 18 faculty members who taught those students. I emailed that faculty group to ask if they were willing to participate in the qualitative part of the study. Finally, I ended up with eight faculty volunteers who were willing to participate in the study. I analyzed their impact on student entrepreneurial intentions and found that they 
had inconsistent effects on student entrepreneurial intentions. I addressed the implications of this Table 38 in this chapter 5. The second purpose was to describe and explain through analysis of interview results how the eight entrepreneurship faculty members define and think about EE and teaching methods (Phase II: qualitative, primary data).

The research questions (RQ) for this study were:

RQ1: As measured by the TPI, how do the faculty beliefs about and experience with teaching in entrepreneurship courses relate to the entrepreneurial intentions level of their students? (quan)

RQ2. How do entrepreneurship faculty describe EE? (QUAL)

RQ3. How do entrepreneurship faculty describe the relationship between entrepreneurship teaching and entrepreneurial learning? (QUAL)

RQ4. How do identified entrepreneurship faculty describe and explain the selection and the use of their pedagogical methods? (QUAL)

RQ5. In what ways do faculty understandings of entrepreneurship teaching and pedagogies (QUAL) help to explore the relationship between faculty perspectives about teaching, the pedagogies they use, and student entrepreneurial intention (quan)? 


\section{Discussion of Results by Research Question}

\section{Research Question 1}

As measured by the TPI, how do the faculty beliefs about and experience with teaching in entrepreneurship courses relate to the entrepreneurial intentions level of their students? (Phase I, quan)

First, I explain and describe the variable of the student entrepreneurial intentions, then, I move on to explain the relationship between student entrepreneurial intentions and entrepreneurial experience by faculty. Next, I describe the relationship between entrepreneurial intentions and the perspective about teaching based on the TPI. Last, I synthetize these results to respond to research question 1.

Change on the student entrepreneurial intentions level. According to the pre and posttest statistical analyses used during Phase I (quan), results demonstrated that a required entrepreneurship class seemed to have no significant statistical impact on the entrepreneurial intentions of Chilean college students as measured by the TPB (Albornoz, 2014), either for the whole sample $(n=2047)$ or the subsample $(n=270)$. Only the subsample is in Table 38. This lack of statistical effect on the student intentions is similar to results found by other researchers. In fact, when evaluating an entrepreneurship teaching program Fayolle et al. (2006a, 2006b), noticed a reduction in the entrepreneurial intention for students having previous knowledge in entrepreneurship.

There might be several explanations for the finding that there was no relationship between student pre and posttest scores on their entrepreneurial intentions. All of the students in the sample in my study were in the freshmen year of their programs. All of 
them took the entrepreneurship class as a required course. I can assume that the majority of students did not have a previous experience in entrepreneurship. Therefore, after taking the class, they may have become more aware of what it really means to become an entrepreneur. What they learned might have scared them or at least discouraged them regarding pursuing a career path in entrepreneurship. Being a required course they may not have been interested in being an entrepreneur in the first place. In addition, they are young. Chile's college freshmen are more traditional in age and are between the ages of 18 to 20 (Albornoz, 2014).

Table 38

Impact of a Required Entrepreneurship Class on Student Entrepreneurial Intentions and its Antecedents Based on the Theory Planned Behavior (Azjen, 1991) Based on Pre and Posttest Scores

\begin{tabular}{|l|r|r|}
\hline Differences on the means on variable & $\begin{array}{c}\text { Pre and } \\
\text { posttest }\end{array}$ & $\begin{array}{c}p \text {-value at } \\
0.05 \alpha- \\
\text { level }\end{array}$ \\
\hline $\begin{array}{l}\text { Global student entrepreneurial intention } \\
\text { Student entrepreneurial intentions }(n=270)\end{array}$ & 0.248 & 0.529 \\
& & \\
Antecedents of entrepreneurial intention & -0.052 & 0.831 \\
1. Attitudes toward entrepreneurial behavior $(n=270)$ & -3.428 & 0.848 \\
2. Perceived behavioral control $(n=270)$ & -0.430 & $* 0.025$ \\
3. Subjective norm $(n=270)$ &
\end{tabular}

*. Significant at the 0.05 level (2-tailed).

Table 38 shows the antecedents of the entrepreneurial intention based on the TPB (Azjen, 1991) as well as the "global" score on a set of items in the survey. Table 38 shows that for the subsample of students $(n=270)$ for whom I had pre and post data, the only antecedent that was statistically significant was the subjective norm. The other antecedents, attitudes toward entrepreneurial behavior and perceived behavioral control, 
were not significant. Attitudes toward entrepreneurial behavior refer to the evaluation of the idea of becoming an entrepreneur made by the student. Perceived behavioral control concerns the perception of the difficulty or ease of developing a behavior, which takes into account past experiences, deficiencies, and obstacles. In this case, it regards student perception of the difficulty or ease in becoming an entrepreneur. Results from my study show that the mean difference between these two variables was not statistically significant.

The third dimension, the subjective norm, was statistically significant. The subjective norm relates to how the students perceived the support or lack of support from others about whether they can actually perform the behaviors expected when acting on an entrepreneurial idea. The variable, subjective norm, had a significant and negative difference between pre and posttest. One explanation for this negative result might be that the students might have known more about what the kind of support it takes to be an entrepreneur. Given that knowledge, they may have felt that they would receive less support from their significant others in terms of their own capability to act as an entrepreneur.

The results described above can be possibly related to the fact that currently in Chile, the higher education system has been experiencing criticisms due to their lack of equity and quality education, especially for private institutions that focus on making a profit rather than educating students as good citizens. Therefore, for some students and their families, becoming an entrepreneur under the traditional view of entrepreneurship that focuses only in economic value creation rather than social change may not be viewed 
in a positive light. Currently, Chilean higher education system and universities are starting to show more interest in the social aspect of entrepreneurship such as social entrepreneur or an intra-preneur rather than a profit-driven entrepreneur. This might offer further explanation for the negative statistical relationship for the subjective norm.

Another aspect that is worth noting is that the students in the sample do not choose the entrepreneurship class voluntarily. This class was part of their required program. Therefore, it is highly possible that the students do not have a desire to become an entrepreneur. They have to take the class for the credits to complete their program. Data should be collected in the future from voluntary entrepreneurship classes to understand more about student views of support they might receive for being an entrepreneur (Albornoz, 2012).

When Jun, Qian, Miao, \& Fiet (2014) did a meta-analysis of 70 studies with almost 40,000 participants they found mixed results on the relationship between EE and entrepreneurial intentions. The authors argue that overall, EE has a statistically significant but small positive relationship with entrepreneurial intention. Also, in a study of Brazilian higher education, Lima, Lopes, Nassif, and da Silva, (2015) found that EE has a significant and negative effect on entrepreneurial intention. These authors mentioned that the lack of positive impact on the entrepreneurial intentions level by a required entrepreneurship class could be explained by the relative heterogeneity of the students, especially regarding their prior knowledge of entrepreneurship and their initial intention levels. Heterogeneity and lack of prior intention could provide explanations for 
why some recent studies did not find any significant positive effects when evaluating EEP.

In sum, this study showed no significant impact on the global student entrepreneurial intentions nor on the attitudes toward entrepreneurial behavior and the perceived behavioral control, as antecedents of the TPB. Even the effect on the third antecedent, subjective norm was statistically significant but negative. In general, based on the results from the survey, I can conclude that EE at the college or university level in Chile did not impact student entrepreneurial intentions after taking the class. It may be interesting for further research to question whether the definition of entrepreneurial intention as used in this study, was the best measure to evaluate the impact of EE. Next, I summarize the relationship between intention and the experience of faculty.

\section{Entrepreneurial experience by faculty and student entrepreneurial intentions.}

Quantitative results in Phase I indicated that the student entrepreneurial intentions are related with the variable of past or current experience of entrepreneurial activity among faculty regardless of whether they are or are not entrepreneur. In fact, when the faculty who taught the class has not been an entrepreneur, students positively change their entrepreneurial intention by more than 2 points and these results are statistically significant, as Table 39 shows. In regards to the variable of current faculty entrepreneurial experience, the impact on the student entrepreneurial intentions is also positive and it is statistically significant, but the change is less strong than in the previous case. The impact is slightly over 1 point; however, it is statistically significant. 
Table 39

Summary of the Impact of the Required Entrepreneurship Class on the Global Student Entrepreneurial Intentions and the Entrepreneurial Experience by Faculty

\begin{tabular}{lcr}
\hline $\begin{array}{l}\text { Difference in the student entrepreneurial intentions } \\
\text { (difference between means pre and posttest }(n=270))\end{array}$ & $\begin{array}{c}\text { Pre and } \\
\text { posttest }\end{array}$ & $\begin{array}{c}p \text {-value at } \\
0.05 \alpha \text {-level }\end{array}$ \\
\hline $\begin{array}{l}\text { When the faculty who taught the class had no past entrepreneurial } \\
\text { experience }(n=270)\end{array}$ & 2.120 & $* 0.008$ \\
$\begin{array}{l}\text { When the faculty who taught the class had no current entrepreneurial } \\
\text { experience }(n=270)\end{array}$ & 1.326 & $* 0.021$ \\
\hline *. Significant at the 0.05 level (2-tailed). & &
\end{tabular}

Based on these results, I can conclude that non-entrepreneur faculty can have a positive impact on student entrepreneurial intentions. These elements demonstrate statistically significant and positive differences between pre a posttest on the student entrepreneurial intentions.

Another variable if the TPB that shows statistical significance is the attitude toward entrepreneurship. When the faculty member who taught the class was an entrepreneur, the effect on students' attitudes was significant and negative. This is different than the other case, when the faculty has not been an entrepreneur. In that case, the effect on the attitudes is significant and positive. 
Table 40

Summary of the Impact of the Required Entrepreneurship Class on the Antecedent of the TPB: Attitudes Toward Entrepreneurial Behavior and the Entrepreneurial Experience by Faculty

Difference in the attitudes toward entrepreneurial behavior

(difference between means pre and posttest $(n=270)$ )

$\begin{array}{lc}\text { Pre and } & p \text {-value at } \\ \text { posttest } & 0.05 \alpha \text {-level }\end{array}$

When the faculty who taught the class had past entrepreneurial experience

1.187

$* 0.016$

When the faculty who taught the class had current entrepreneurial

$-0.667$

$* 0.046$ experience

*. Significant at the 0.05 level (2-tailed).

\section{Perspectives (beliefs) about teaching based on TPI and student}

entrepreneurial intentions. The ANOVA test results indicated that the entrepreneurial intentions of students in the case of the subsample $(n=270)$ were not significantly related to the faculty teaching perspectives (the combined five categories nor the individual category scores) as measured by the TPI. The TPI has five different categories:

transmission, apprenticeship, developmental, nurturing, and social reform (Pratt, 1998). The results showed that the global student entrepreneurial intentions were not impacted by the teaching perspective of the faculty as measured by the inventory.

Even though these results in statistical terms are insignificant, and even though they do not have any impact on the students' entrepreneurial intention, it is worth noting that these perspectives described the teaching profiles from the faculty subsample $(n=$ 18). Figure 15 shows the scores for each of the five teaching profiles for the faculty subsample as well as the mean score by perspective. Figure 15 shows the scores that faculty obtained in the TPI. The horizontal axis provides the scores of each of the faculty 
and the overall mean from the subsample $n=18$ ). Figure 15 also shows that the apprenticeship profile shows the highest mean score (39.22) with a standard deviation of 3.332 compared to the rest of profiles. The apprenticeship profile is the most characteristic teaching perspective even when I compared the scores with the other profiles. In total, apprenticeship has a difference of 1.278 with nurturing, 2.833 points more than the developmental profile, 3.278 points of difference with transmission, and 4.278 more points than the social reform profile, as I described in chapter 4.

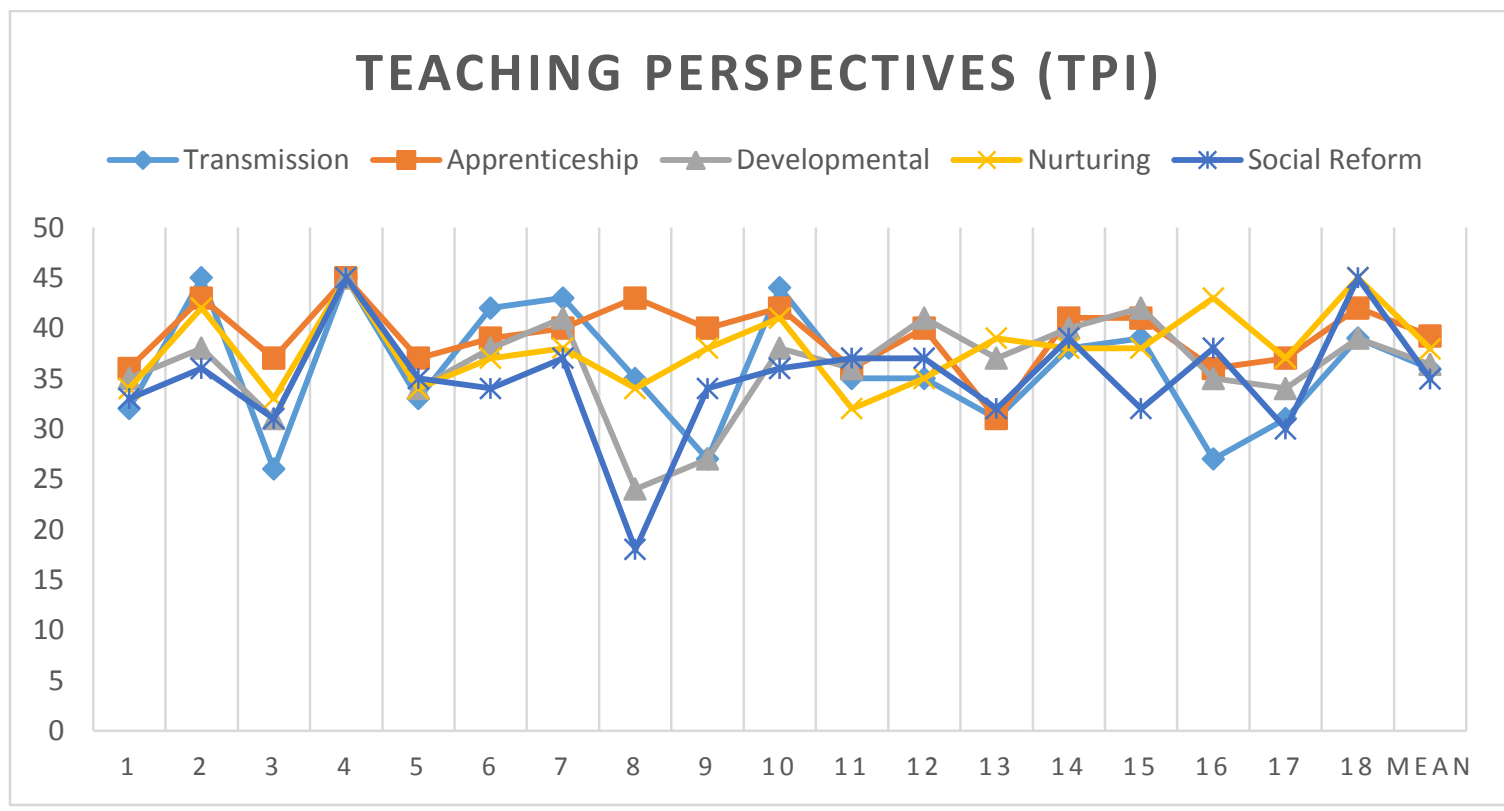

Figure 15. Graphic representation of the teaching profiles by Chilean entrepreneurial faculty.

According to Pratt (1998; 2005), beliefs govern the practice of teaching. Faculty with apprenticeship as the dominant teaching perspective believe that learning is not possible without practice. They also conceive of themselves as role models shaping the future practice of their students. These results, showing that the apprenticeship is the 
most characteristic teaching perspective among entrepreneurship faculty in the case of sample of 18 faculty. A total of 9 out of 18 faculty had as apprenticeship the highest scores. These results are similar to the results founded by Albornoz (2012).

The nurturing profile follows (37.94) apprenticeship. Nurturing profile is the second most important trend on the teaching perspectives from this subsample. Faculty, who have a nurturing profile respect students and care about them. They are committed to the developing the whole person and to creating a balance between challenge and support (Pratt, 2005).

The third highest mean teaching profile was the developmental profile whose mean was is 36.39 . From a developmental perspective, teachers are concerned about the student prior knowledge in regard to their content knowledge and skills. Faculty who hold this perspective as dominant believe in changing cognitive structures of students related to thinking about the content.

In sum, results from these analyses show that there were no significant differences in the student entrepreneurial intentions after taking a required entrepreneurship class in Chilean universities. These effects were similar to those results reported by Oosterbeek, van Praag, and Ijsseltein (2010) when they analyzed the impact of a leading EEP on college students' entrepreneurship skills and motivation. The authors found that the effect of the program on students' self-assessed entrepreneurial skills was insignificant and the effect on the intention to become an entrepreneur was even negative. According to these authors, the negative or even insignificant change in the intention to become an entrepreneur could be due to the student gaining a more realistic view of what is needed 
to start one's own business. Hence, even it is possible that students feel less attracted to pursuing an entrepreneurship career due to the real experiences and challenges that entrepreneur-faculty shared.

In sum, the relationship between the combined and individual faculty teaching perspectives on the TPI and global student entrepreneurial intentions was not statistically significant. When I examined the relationship between faculty experience or nonexperience as entrepreneurs and student entrepreneurial intentions, the relationship was statistically significant (Tables 38 and 39). However, this result did not seem to proceed in a logical direction, that is, the faculty with internship experience having the most impact on student entrepreneurial intentions. In fact, the opposite was statistically significant. When faculty had not ever been or currently were not an entrepreneur, the change in the student entrepreneurial intentions was statistically significant, indicating positive differences between pre a posttest. Therefore, there is some relationship between faculty not being an entrepreneur and positive student entrepreneurial intentions. These results were further analyzed in Phase II of this research study and that helped me to understand more about this significant finding.

\section{Research Question 2}

How do identified entrepreneurship faculty describe EE? (QUAL)

All of faculty participants in this study in the interview shared the idea that EE is more than the process of creation of a new venture or start-up. In fact, the majority of faulty mentioned that EE is a life attitude that focuses specifically on the developing of entrepreneurial competencies, skills, attitudes and spirit. In chapter 4, I provided evidence 
from the interview transcripts to describe the perspective on EE that faculty have. Figure 16 shows a graphical representation using thematic network analysis that synthetized the basic and organizing themes that emerged from qualitative data in regards to how faculty describe EE.

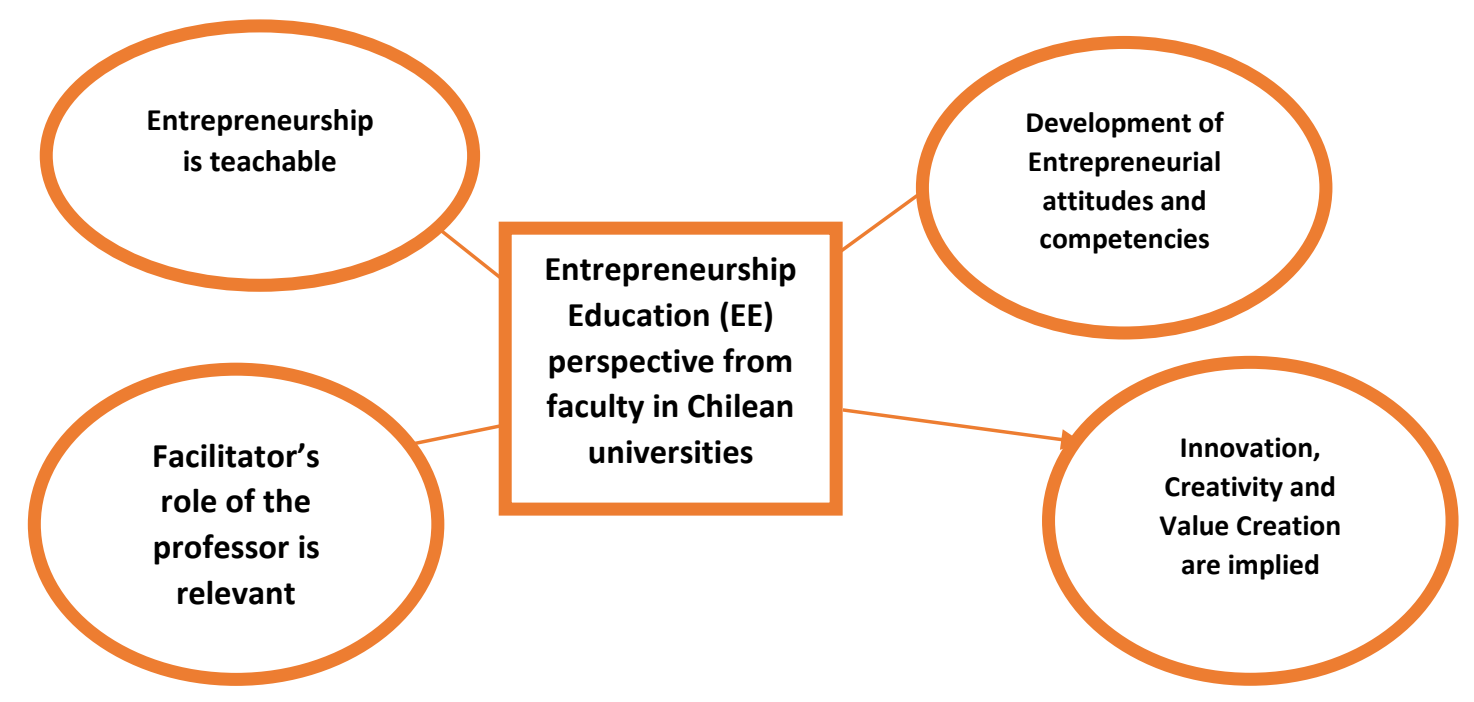

Figure 16. Thematic network summarizing how Chilean faculty describe EE.

As an example of a faculty description of EE, Horacio, an entrepreneurial faculty

who is in his mid-twenties and had current and past entrepreneurial experience said:

I think [entrepreneurship] is more or less as an attitude towards life. I see it that way, that a person, because it also can be intra-entrepreneur, may be within an organization and do something new. In the background is a different attitude "I want to do something," "I am not indifferent to things that are going on," then "I want to take care of that, or solve problems for both my organization or outside, or a social problem, and so not even ... political project," but I see it [entrepreneurship] as an attitude toward life, and that attitude can be learned and can be delivered just as other skills.

This quote shows that Horatio's perspective about EE encourages students to be creative and innovative in solving problems and also in finding opportunities to solve 
those problems. Faculty members mentioned that students have to be active participants during classroom activities.

Also, the majority of them mentioned their role as facilitator of student activities, giving the students ongoing feedback about their classroom participation and activities. Another professor, Katy, mentioned that her course "is beyond the development of a new business or venture" and Manuel stated,

I believe very much in entrepreneurship with innovation, that is, for me these are not two different aspects. Entrepreneurship works with innovation. Some universities may see these two as very different issues. That is, entrepreneurship simply generates business. No. The project has to go with innovation to address future sustainability issues. We touch the topic of innovation in my class from the first minute students walk in.

Manuel shows that entrepreneurship implies innovation and creativity.

Fayolle (2013) and Fayolle and Gailly (2015) suggested that to improve research in EE, educators and researchers might use the concept of teaching models (B Béchard \& Grégoire, 2005) to reflect on the philosophical and ontological level of EE. According to Fayolle (2013) "the philosophical level aims at defining the teaching object and the concepts of education that guide and determine the roles of educators and participants in a given EE intervention" (p. 695). These authors claimed that in order to move EE forward researchers need to ask questions such as: (a) What does entrepreneurship mean?, and (b) What are the respective roles of educators and participants?

Regarding the first ontological question about what entrepreneurship means from an educational perspective, some organizing themes that emerged from the data were useful to help me to analyze this issue. From the interviews, there were some examples of the vision of EE that faculty have. One recurrent theme was that EE is more than the 
creation of a business but it is also a way of thinking that implies innovation and creativity.

The themes that emerged from the analysis of the interviews followed a Schumpeterian school of thought about entrepreneurship (Schumpeter, 1934). Schumpeter advocated a creative approach to entrepreneurship. This perspective on entrepreneurship argues that the entrepreneurs are innovators who create or discover something new to break the market equilibrium (Wang \& Chugh, 2014). In fact, Gibb (2002) argued that the Schumpeterian perspective sees the entrepreneur as a person who creates opportunities to generate social, environmental, and economic value through the process of doing something innovative. Similar vision of EE was shared by faculty in the study. However, even though this perspective implies the use of innovation and creativity, according to more recent entrepreneurship research, this viewpoint is still seen as a traditional point of view in EE (Fayolle, 2013)

The interview results indicate that faculty participants are teaching entrepreneurship under the umbrella of the Schumpeterian school of thought (Schumpeter, 1934) rather than under the school of Kirzner $(1973,1979)$. Kirzner's school of thought is a discovery approach that means that entrepreneurs find opportunities that already exist out there in the environment. In contrast, the school of Schumpeter believes that the entrepreneurs are the person who creates opportunities on their own not in response to the environment. Indeed, Schumpeterian's perspective on entrepreneurship research sees entrepreneurship as the process of identifying and exploiting opportunities (Shane \& Venkatamaran, 2000). 
Regarding the second ontological question from Fayolle (2013) and Fayolle and Gailly (2015) about what are the respective roles of educators and students, qualitative data from faculty interviews indicated that faculty considered $\mathrm{EE}$ as a process-oriented field. To these faculty, the primary role of the teacher was to be a facilitator during student classroom activities as well as to provide feedback to students. To meet these classroom objectives, faculty noted that it takes a significant amount of time prior to the class as well as extra help with their teaching workload. As an illustration, Jenifer mentioned that she has "the job of being a facilitator rather than being the center of the class. That is here in my class, the student is the center, and I am doing the role of facilitator versus the faculty being the center and everyone is listening to me." Indeed, Jennifer emphasized that "there are faculty profiles that lead to students being less communicative. When faculty are talkative and are not comfortable with the facilitator role, then they become the center of the class. As a facilitator, therefore, I need more time to prepare, plan, evaluate, search for material and innovate in my teaching." These quotes from Jenifer and others in chapter 4 are evidence that faculty are aware of the need to be a facilitator in their classroom activities, especially in entrepreneurship classes. Being a facilitator could be an essential condition for becoming a teacher of entrepreneurship.

Regarding the role that students have in EE, faculty mentioned that students have to take an active role inside classrooms and be participants rather than just listeners. Faculty also mentioned that skills such as perseverance, motivation, and autonomy are relevant for becoming entrepreneurial individuals. However, they also shared that it is sometimes difficult to teach freshmen students when the faculty themselves do not have 
the specific education and pedagogical training about how these young students learn. In fact, Jenifer, a non-entrepreneur faculty in her mid-forties claimed that teaching entrepreneurship to freshmen is a challenge because students require interesting activities to be engaged. She stated,

the interesting thing is that they [students] are like new kids. Students are very enthusiastic. They are highly motivated. They can work and take advantage of that situation because they are very participatory. Then, any activity you do in this area, for any methodology, they are active, they integrate and participate more playfully. Yes, the course is fun. I give to [them] a whole series of activities and that engages them very well. And in parallel, I develop the simulation project. And, to the extent that they are motivated to engage in the same topic, they care and do the work.

In addition, Sergio, an entrepreneur faculty with more than 15 years of experience teaching entrepreneurship states clearly that

[it is] important for students to draw on their own experiences, to write them, to describe them. I say [to them] theory, hey, 'Dr. Google' exists, he teaches them all, that is ... how to make noodles. I tell them when I'm alone and I want to cook, then I look into Google, and Google knows everything. Then do not ask me. I tell them the same thing, because it would be boring, you had better share experiences and talk about them.

This quote illustrates how student participation in classes with the rest of their

peers is important to the professor. He seeks to make the course relevant and pertinent to their lives. The class is alive with many moments for personal engagement and learning.

Faculty shared a common perspective of EE, that is, entrepreneurship is more than the creation of a business. And, for all of them, it is a teachable subject. Their perspective that entrepreneurship is teachable coincides with the work of Neck \& Greene (2011) and Seelig (2015).

However, the faculty interviewed often mentioned that entrepreneurship is difficult to teach and that this impacted their decision-making regarding what contents are 
teachable and what are not. Fiet (2001) wrestled with this problem that some elements of EE are teachable and others are not and that faculty need support on this specific aspect on EE. For example, Jenifer mentioned some teachable elements in EE. She mentioned “ I also think that perseverance comes with the students and cannot be developed. That is, the person already has perseverance, and to be an entrepreneur you have to be persistent; you have to have tolerance for frustration. And neither can be taught. However, there are other things, communication, planning, teamwork, leadership to some extent, those you can form, but, however, I also ... we do not want all students to be (profit-driven) entrepreneurs, but nevertheless if you develop these other skills, we can foster intra-entrepreneurs. Then this conviction (teaching intra-entrepreneurs) motivates me a little to teach the subject of entrepreneurship.

Most of the faculty felt like Jenifer. Entrepreneurship is a valuable type of education that goes beyond the process of business creation and is more related to the development of entrepreneurial competencies, skills, attitudes and spirit. This aligns with a process-oriented view on EE rather than a practice-based approach (Neck and Greene, 2011; Neck et al., 2014). Faculty share the same perspective on EE. Faculty interviewed also lacked the knowledge of different theories on entrepreneurship.

Faculty in the study reported that they used a traditional perspective of EE, a process-oriented approach leading often to the development of a business plan. However, Sarasvathy (2008b) emphasized that entrepreneurship teaching should embrace a more practice and action-oriented approach that implies being creative and simulating how entrepreneurs think. Neck \& Greene (2011) suggest that an action-oriented approach should be accompanied by reflective practice (Neck \& Greene, 2011). Faculty do not report that they use these action-oriented approaches and reflective practice activities in their teaching. Fayolle and Gailly (2015) and Fisher (2012) called for research on the use of action-oriented approaches and reflective practice in EE classrooms. However, faculty 
members need to be taught how to use these new ideas effectively. Therefore, I argue that faculty need to participate in professional development activities to make these needed changes.

\section{Research Question 3}

How do identified entrepreneurship faculty describe relationship between entrepreneurship teaching and entrepreneurial learning? (QUAL)

Figure 17 summarizes the vision that the interviewed entrepreneurship faculty have with regards to entrepreneurship teaching and types of learning. As I mentioned in chapter 4, I produced this thematic network by clustering what I am calling basic and organizing themes extracted from interview transcripts relating to teaching and learning.

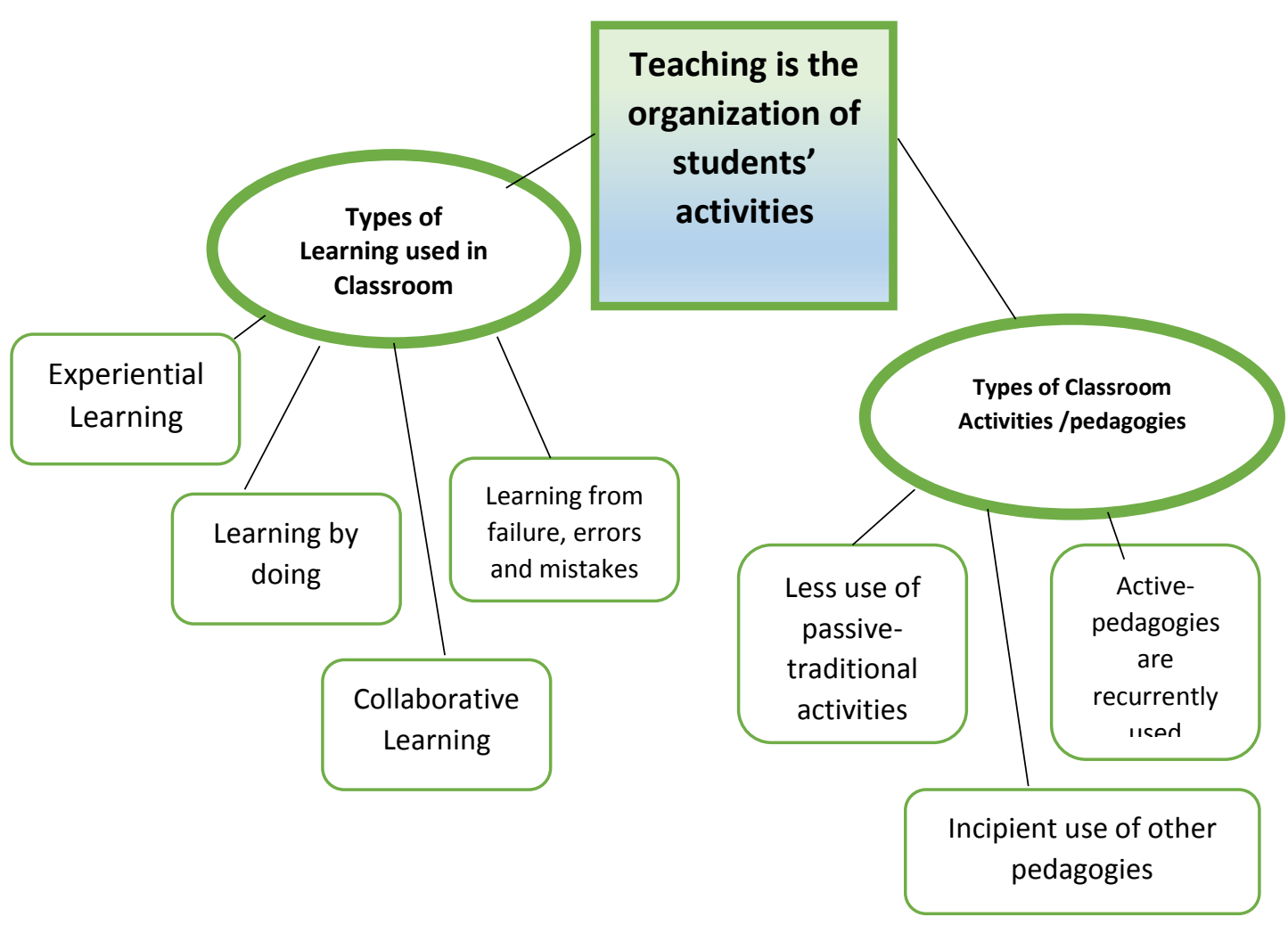

Figure 17. Thematic network that synthetizes the relationship between entrepreneurship teaching and learning among faculty in Chilean universities. 
Most of the entrepreneurship faculty interviewed appeared to believe that teaching in entrepreneurship means organizing activities for students and engaging them in the process of learning. Faculty members expect students to be active participants, and they see the faculty role as facilitator of these activities. Indeed, despite articulating the idea that $\mathrm{EE}$ is about the process of developing entrepreneurial skills most of their pedagogies focused on business plans and exercises related to the development of that plan.

The only faculty member that mentioned that he was developing student skills through a series of activities was Silvio. He noted

I would define entrepreneurship education as entrepreneurial skills development, and one of the things that has concerned me a lot, is how to define what those entrepreneurial skills are. For example, I have focused on developing the spirit of observation, overcoming the fear of risk, for example, and that is why my teaching methodology is geared to skills development. Skills are developed based on continuous practice in certain areas, to break the habits of the past.

Not only did Silvio talk about the need for skill development, he also reported specific activities that developed these skills. He was the only faculty member who focused on skill development both in his definition of EE and also in his description of his classroom practices.

The interviews showed that faculty have a need to know more about what it means to teach entrepreneurial skills or competencies as well as how to assess them. This lack of coherence between how faculty members define EE and what activities they describe in their classroom practices was a recurrent theme during the interviews. The lack of coherence can be addressed by future professional development that includes reflection on different teaching models, such as suggested by Fayolle and Gailly (2015). 
I used the perspectives on teaching models or approaches in EE based on Neck and Greene (2011) and Béchard and Grégoire (2005) to create a graphic representation (see Figure 18) to localize the perspectives that faculty shared in regards to teaching entrepreneurship based on their interviews.

Neck and Greene (2011) noted that there is no single entrepreneurship teaching approach in universities. Fayolle (2013) suggested that it is important to have coherence between how we define entrepreneurship and the methods used to teach it. There are two classifications of approaches to teaching that I referred in the literature review that I want to reconsider as I analyze Research Question 3. One of these perspectives is based on the work of Neck and Green's typology of four different approaches that classify EE in terms of how it is considered as a teaching subject: EW, EP, EC, and EM. These approaches range from the more "process-oriented" approaches (EW, EP, EC) focused on the entrepreneur to the approaches that are more "action-oriented" (EM). The former approaches, the process-oriented ones, focus on developing the business plan. The latter approach helps students to adopt entrepreneurial behaviors and to develop an entrepreneurial mind through practice (Neck et al., 2014).

The current environment for EE is changing rapidly and has high levels of uncertainty. Various researchers in EE claim that process-oriented teaching approaches are not the most effective nor realistic for the current environment of entrepreneurship (Neck \& Greene, 2011; Tounes et al., 2014; Sarasvathy, 2008a). In fact, Gibb (2002) and Krueger (2007) claimed that traditional teaching methods do not activate entrepreneurship because they inhibit the development of student entrepreneurial 
attitudes and skills. Therefore, a fundamental feature of EE should promote EE through action-based pedagogies (Neck \& Greene, 2011).

Another classification of approaches to EE is based on the work on Béchard and Grégoire (2005). These authors identified three teaching models or archetypes for teaching entrepreneurship at the higher education level: (a) the supply model, (b) the demand model and (c) the competence model. These three models describe different conceptions about philosophy of education and pedagogical choices by educators. On one hand, the supply model says that teaching should impart information as well as telling a story. In this model the teacher is a presenter and the students are passive recipients. Faculty interviews indicated that their philosophy and pedagogical choices were far away from the supply model, even though they sometimes use some traditional pedagogies such a lectures to develop content knowledge. The demand model describes teaching as the organization of activities. Finally, the competence model envisions teaching as a conversation in which mediation between the educator and students about the knowledge that needs to be learned makes learning possible. In this competence model, the professor serves a coach and developer rather than a facilitator and the students are seen as active participants in the co-construction of their knowledge.

On the horizontal axis on Figure 18 there are the three different models of teaching entrepreneurship from Béchard and Grégoire (2005) and on the vertical axis there are the four different approaches by Neck and Greene (2011) that are: EW, EP, EC, and EM. The content of the figure shows the relationship between these two constructs. Also, Figure 18 illustrates that faculty from the subsample of their interviews were 
mostly focusing their teaching practice on the demand model of teaching (Béchard \& Grégoire, 2005) between the supply and the competence models. Thus, the faculty teaching method was characterized by the demand model because faculty focused on teaching as assuring student appropriation of knowledge as well as organizing the students' classroom exercises and activities. This is in contrast to the competence model where students are immersed in real world problems and situations (Robinson \& Shumar, 2014).

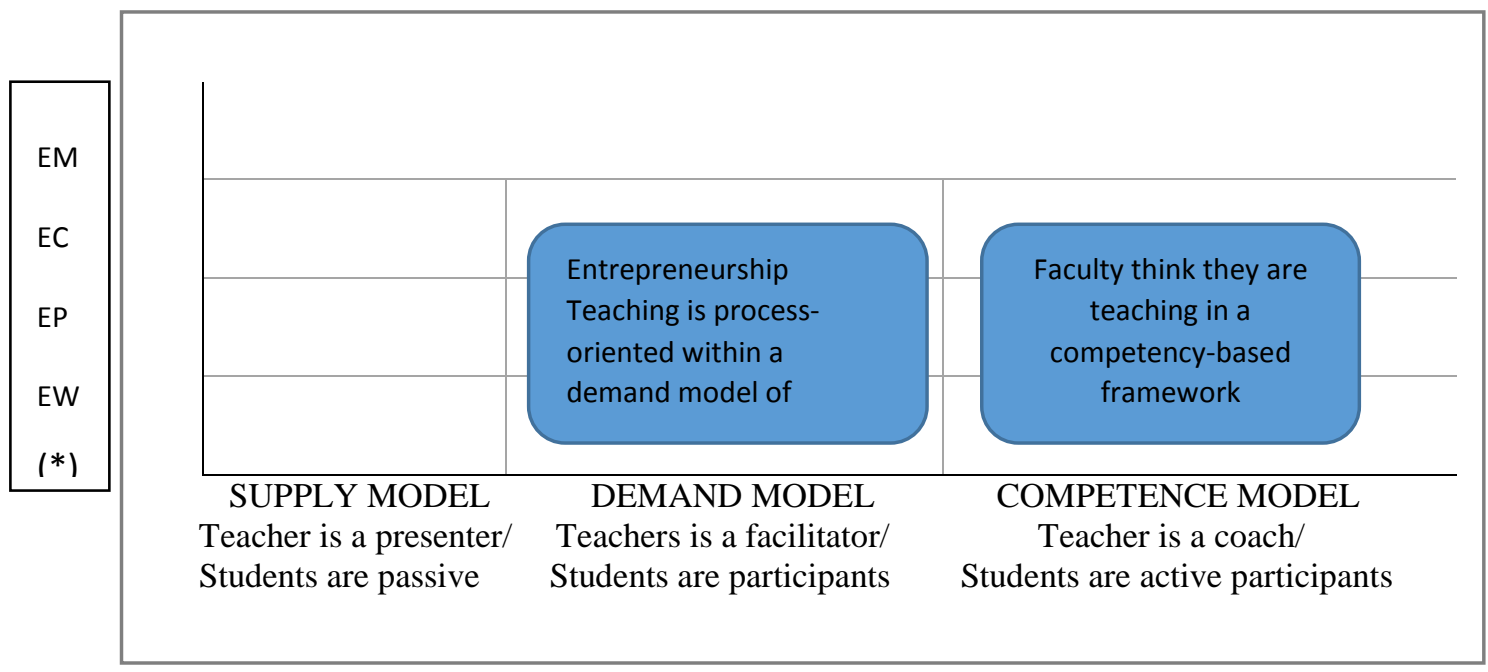

(*) EW) Entrepreneur World, (EP) Entrepreneurial Process, (EC) Entrepreneurial Cognition, (EM) Entrepreneurial Method.

Figure 18. Approaches of teaching entrepreneurship at universities based on Béchard and Grégoire (2005) and Neck and Greene (2011).

Therefore, drawing insights from these teaching models and approaches in EE as well as from the qualitative data from faculty interviewed, I found that there is a difference between faculty teaching ideals and the actual activities in classroom practice. There is an discrepancy among what topics want or desire to teach students, what their 
syllabi say regarding the main goal of the entrepreneurship course, and what faculty describe they are actually doing in their classroom activities as teaching practices.

My findings suggest that their actual practice showed evidence that faculty are teaching according to a demand model, but when faculty mentioned the main goal of their classes and activities, the majority of them mentioned that they want develop competencies and skills among their students, which means working in relation to a competence model of teaching. This is the discrepancy that I found. This suggests that there is a need to increase the coherence between the ideal and current practices among faculty in EE as well as the goals or outcomes that universities and faculty want to pursue.

In sum, my conclusion is that for the teachers I interviewed, EE is considered as a process-oriented approach. This is the most used and most often mentioned approach in EE according to recent entrepreneurship textbooks and research (Neck et al., 2014). In recent years, the entrepreneurship-as-process approach has had a stronghold in EE, and it has been difficult to move EE forward to other approaches. EE as a process-oriented approach of teaching has been influenced by the academic background of the scholars in the field of strategic management (Neck et al., 2014).

The findings in this study may be explained in part by the fact that the majority of the faculty from this study are from business and management fields. However, currently, some researchers in EE argue that in order to move teaching in entrepreneurship to the next level in terms of helping students think more entrepreneurially, faculty and programs should consider that the process-oriented approach to teaching is not the best alternative. A better option is to consider entrepreneurship as a "method" for dealing with a future 
that is not predictable, but can provide innovative solutions to current problems in uncertain environments, a more practice-oriented approach (Neck \& Greene, 2011; Sarasvathy, 2008b).

Hence, if there is a need to move the field of EE forward in terms of teaching and learning, the question of how entrepreneurship should be taught is not as relevant as how entrepreneurship should be learned. The more accurate question to ask in EE is, how should entrepreneurship be learned? It is this type of framework that will help students act and think more entrepreneurially (Robinson \& Shumar, 2014; Sarasvathy, 2008a).

\section{Research Question 4}

How do identified entrepreneurship faculty describe and explain the selection and the use of pedagogical methods? (QUAL)

The faculty interviewed used different types of pedagogies in their entrepreneurship classes. I classified the total of 31 pedagogies mentioned by faculty into three groups of pedagogies. For the analysis I added a new category named "other pedagogies" because these other pedagogies seemed to be very interesting to some of the faculty, but they have not yet been sufficiently recognized and discussed empirically in the context of EE.

Figure 19 shows the list of pedagogies mentioned by faculty participants in their interviews. A total of 31 pedagogies were extracted from the interview. "Traditional or passive pedagogies" represent $14 \%$ of the total. The next category is the pedagogies classified as active-based categories representing $49 \%$ of the total. The last category that I found that faculty frequently mentioned were the category I classified as "other 
pedagogies" representing $37 \%$ of the total. Among the "other" pedagogies, faculty reported some of them that have been adapted pedagogies from American universities as well as others from Chilean faculty. These include: Business Model Canvas by Alexander Osterwalder, elements of the process of Design Thinking ${ }^{\circledR}$, and the Elevator Pitch.

These pedagogies have been implemented recently and faculty noted that they were brand new in Chilean EE. Little empirical research has been done on these other pedagogies, especially in Chilean universities.

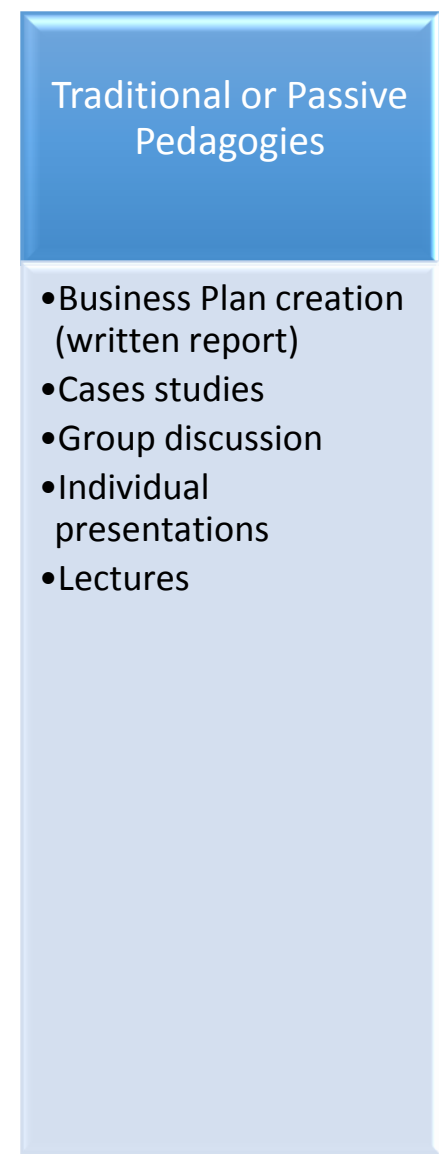

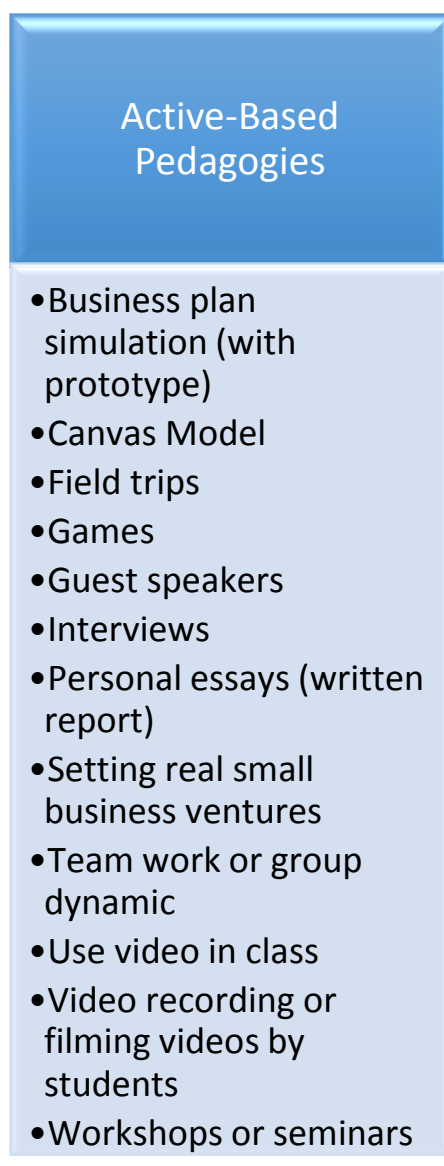

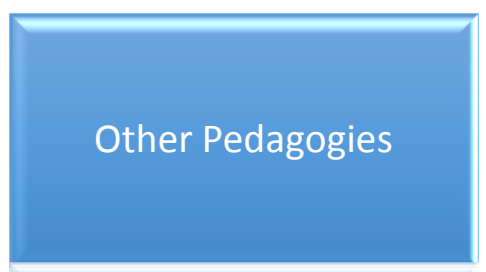

-Art and music in classroom

-Brainstorming

- Clickers (Tecleras)

- Coaching to students

-Design thinking (elements of)

- Effectual thinking

- Elevator Pitch

- Enneagram

- Entrepreneurial fair

- Feedback students

- Keeping a journal

- Observations

- Poems

- SWOT (Strengths, weaknesses, opportunities, and threats)

Figure 19. Classification of different types of pedagogies across faculty. Pedagogies are listed in alphabetical order. 
Faculty reported that traditional or passive pedagogies are less commonly used than active-based and other pedagogies. On average, "traditional pedagogies" represent $14 \%$ in comparison to "active-based" and "other pedagogies" which represent $49 \%$ and $37 \%$ respectively (see Figure 20 last column).

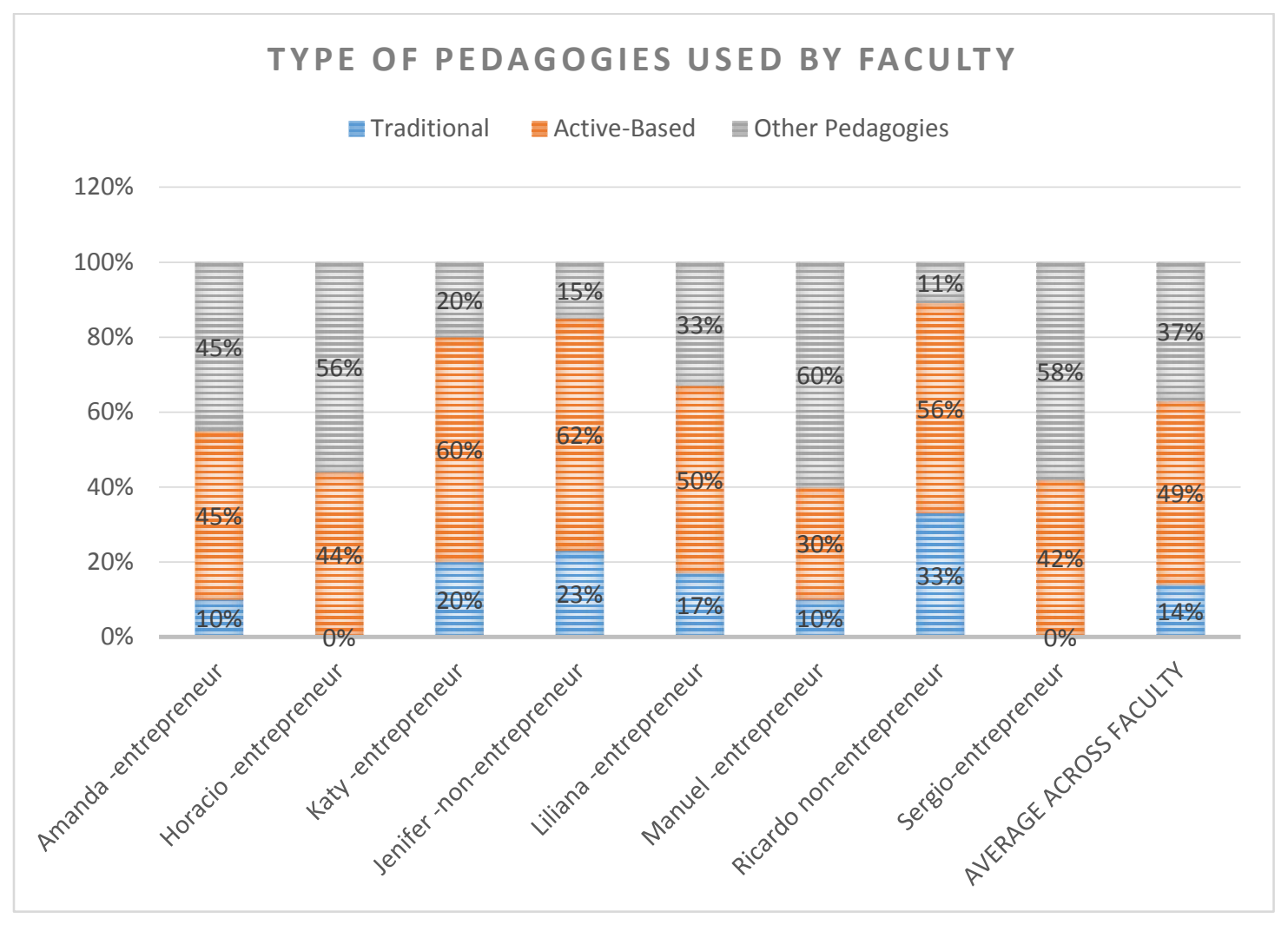

Figure 20. Types of pedagogies used by the individual faculty and backgrounds.

Among the faculty interviewed, I saw that they use a mix of pedagogies. Some of them mentioned that they have been adapting pedagogies in a process of a trial and error with students. For instance, Katy, an entrepreneur faculty with a business background mentions that she uses a "potpourri of types of styles, starting with the traditional, which is the power point and the lectures...I also did many workshops, workshops in groups 
work and workshops during all the course." This quote shows evidence of the typical mix of pedagogies that faculty mention.

Faculty used a mix of different pedagogies and activities that combined less use of traditional pedagogies and more use of active-based pedagogies such as the business plan as a written report or in simulations environments. Even though faculty participants in the interviews demonstrated they followed a process-oriented approach to teaching entrepreneurship in universities, few of the faculty interviewed were using hands-on and learning-by-doing activities because they are time consuming. Even fewer used personal reflection with students because of the amount of time it took to give feedback to students. It is worth noting that in Chilean universities and especially in these type of classes, there are usually 30 students on average per class; yet, classes can range from 20 to 60 students. As a summary, even though the faculty interviewed tend to be more innovative in adapting pedagogies from other fields and other contexts, especially US contexts, faculty report that they are using a process-oriented teaching approach to entrepreneurship. Also, faculty reported that they used the pedagogy of business plan creation. The business plan as a simulation project was still the most used often by faculty in their courses. This would be considered active-based pedagogy. Yet, it would also be considered very limited in the long run because it does not seem to impact the mindset of an entrepreneur or foster the behaviors of entrepreneurs. 


\section{Research Question 5}

In what ways do faculty understandings of entrepreneurship teaching and pedagogies (QUAL) help to explore the relationship between faculty perspectives about teaching, the pedagogies they use, and students' entrepreneurial intention (quan)?

In this mixed method study that used an explanatory research design, the qualitative data helped the researcher to explore the results from quantitative data. Thus, as a result, this last research question 5 required the examination of the two types of data (quan $\rightarrow$ QUAL) collected during chronological Phases I and II. Results from the Phase I (quan), determined that, from the data collected using the College Student Survey, there was no difference between the global student entrepreneurial intentions from pre to post after taking a required entrepreneurship class. Therefore, in this specific situation, I can summarize that there was no impact of entrepreneurship course on the student entrepreneurial intentions in the immediate term, after finishing the classes, based on student responses to the survey.

There exists a relationship between the entrepreneurial experiences of the subsample of faculty $(n=18)$ and student E intention (Tables 39 and 40). According to the statistical results analyzed during Phase I, the faculty without entrepreneurial experience positively impacted the student global entrepreneurial intention and one of the antecedents, that is, the attitude toward entrepreneurial behavior (Azjen, 1991). The faculty with past entrepreneurial experience had no significant statistical relationship with student global entrepreneurial intentions. The faculty with past experience did seem to impact the antecedent, student attitudes, positively but those with current experience had 
a negative impact on student attitudes. These mixed results seem to indicate that there is a complex relationship between faculty experience and student entrepreneurial intentions. It seems it would be good to do further qualitative research on these phenomena. . In addition, the different teaching profiles derived from the TPI for the subset of faculty $(n=8)$ did not have a statistical relationship with the student entrepreneurial intentions. The overall statistical results demonstrated that the student entrepreneurial intentions did not change after taking the entrepreneurship class. The only exception is the case of Jenifer, who was without experience of being an entrepreneur and, yet, she positively impacted the intention of her students. Table 41 uses data from both Phases I and II of this study (quan $\rightarrow$ QUAL): the entrepreneurial experience of the faculty, the dominant perspective on teaching that each faculty possessed, the quantitative results of the change between pre and posttest of the students' entrepreneurial intention, and the type of pedagogies that the faculty mentioned using during their classes.

As we observe in Table 41, the dominant teaching perspective among faculty was the apprenticeship profile. These results are similar to Albornoz's (2012) research that analyzed the way in which EE faculty selected their goals, content, and methods for their classes. Albornoz found that these selections were based on the apprenticeship model.

From the results and findings in this study, I can identify two main profiles between faculty interviewed. On one hand, there are the "practitioner" faculty who have entrepreneurial experience and, on the other hand, there are the "academic/consultant" faculty without entrepreneurial experience but with more education experience as teachers. To understand and explain these two different profiles that I identified from the 
quan $\rightarrow$ QUAL data, I used the theory-practice matrix proposed by Neck et al. (2014)

regarding entrepreneurship teaching. Figure 21 describes four different profiles of

teaching entrepreneurship at universities, considering the emphasis on theory or the

emphasis on practice that they tend to use. The four profiles are: Genesis, Academic,

Apprentice, and Synthesis.

Table 41

Quantitative and Qualitative Data by Faculty Interviewed

\begin{tabular}{lllll}
\hline & & & & \\
& & & &
\end{tabular}

$(+)$ Entrepreneurship faculty' names are pseudonyms to keep their anonymity in this study.

(*) The perspective that scores the highest, becomes the dominant perspective of teaching for the faculty.

Responses are based on the online survey responses (questions \#2, \#3 \#4 in faculty's survey). The teaching perspective scores range from 9 as minimum to 45 as a maximum (Pratt, 1998). See Appendix A for detail in the TPI scores for faculty interviewed

(**) Significant at the 0.05 level (2-tailed). 
According to the authors, the theory-practice matrix is a useful guide to considering the theory based options (or lack thereof) for teaching entrepreneurship today as well as for understanding the main differences between these types of teaching in EE. According to Neck et al. (2014), entrepreneurship teaching today is moving between the areas in which educators in EE are in the academic cell or in the apprentice cell.

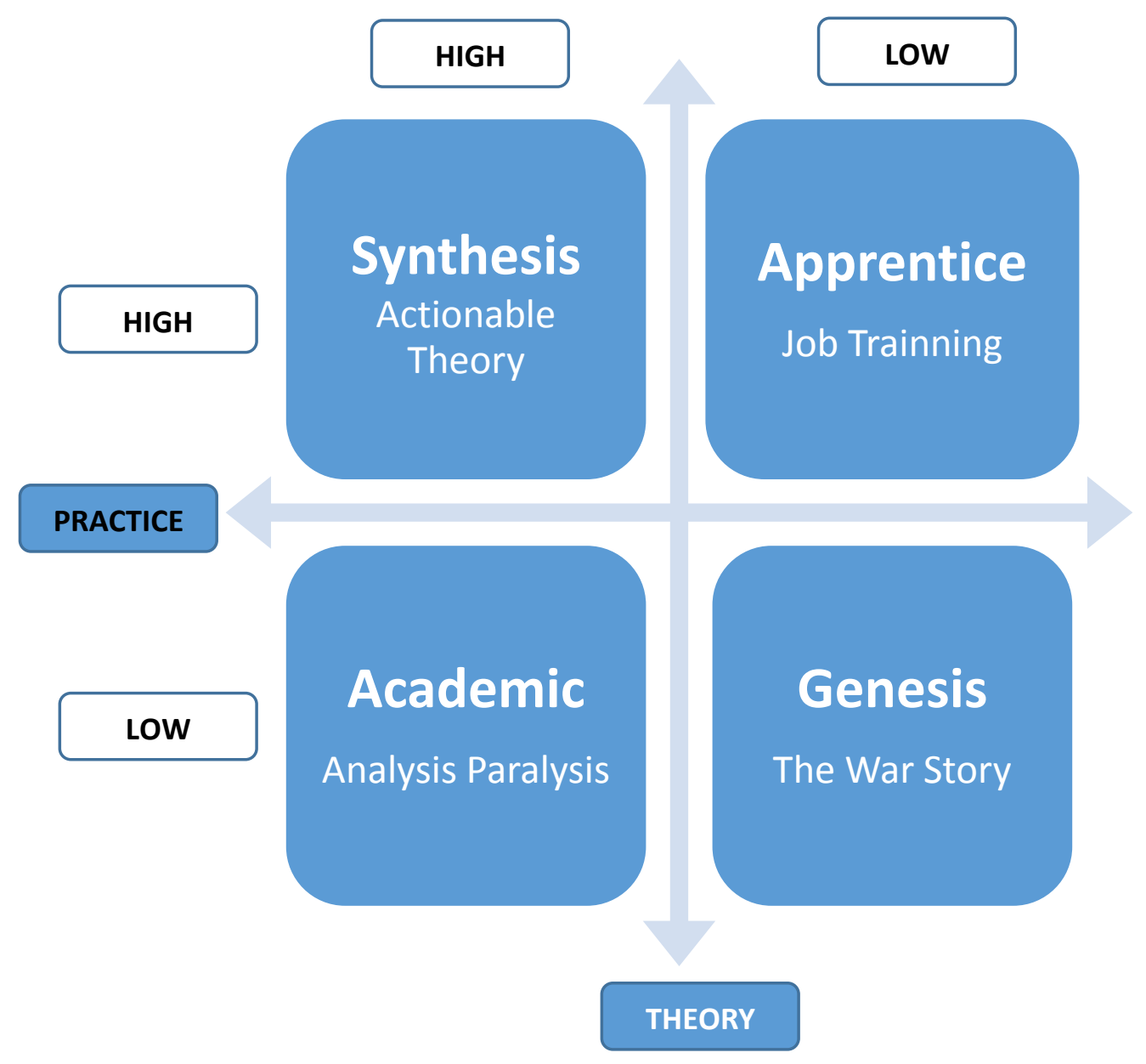

Figure 21. Theory-practice matrix in teaching entrepreneurship. Based on Neck et al. (2014). Horizontal axis represents the high versus low level of practice, and vertical axis represents high versus low level of theory. 
On the one hand, I perceived that faculty who were entrepreneurs were eager to foster entrepreneurial skills and competencies in students through practices that come from their real experiences as entrepreneurs. They were the practitioners who had the experience of creating their own businesses. According to the matrix in Figure 21, I would classify them into the category of Apprentice that means that they are focused on job training. For instance, one entrepreneurial experienced faculty used active-pedagogies, such as filming an interview with an entrepreneur, to infuse discussion among the class. He also used some elements of design thinking such as observation to excite student interest. As the data from interview showed, entrepreneurial-faculty believed that students learn from the experience of doing hands-on activities. These faculty tend to follow some elements of learning-by-doing pedagogies, but they do not necessarily know what these activities really mean. They also do not understand the educational or entrepreneurship theories that can help them to achieve their purpose of fostering entrepreneurial skills in students. I argue that their teaching would be improved if they understood more about the theoretical and pedagogical knowledge of teaching entrepreneurship. In sum, as an outcome for the class, the apprentice perspective leads to a preference for skill and competency development over the development of critical thinking, understanding and developing theory, or practicing reflection.

The study also found that there are faculty who have no real experience in being entrepreneurs. According to the matrix described in Figure 21, the non-entrepreneurship faculty could be classified into the category of "academic" because they support and use 
theory instead on focusing just on the practice. According to Neck et al. (2014) these type of faculty are guided by a sense that theories and frameworks in EE should lead practice.

The apprentice and the academic are two different and complementary faculty profiles. Both are needed to teach entrepreneurship. In fact, when I asked about pedagogies and teaching practices with the two faculty who had no real entrepreneurial experience, they both agreed that a missing piece in their teaching in entrepreneurship was a lack of entrepreneurial experience. Thus, both faculty (Jenifer and Ricardo) tried to incorporate real entrepreneurial experience using current entrepreneurs as guest speakers in the classroom.

In addition, a recurrent issue mentioned by all faculty participants was the importance of being an entrepreneur to be able to teach entrepreneurship because these faculty can teach about entrepreneurship from their own experience. For instance, Liliana, an entrepreneur faculty claims that "I cannot imagine someone who is teaching an entrepreneurship class, who has never been an entrepreneur, and because you have to teach students how to overcome difficulties." Hence, there is an implicit value placed on real experience of entrepreneurship that a faculty possessed compared to the nonentrepreneur faculty.

In sum, non-entrepreneur faculty were aware of their lack of real experience as an entrepreneur. Yet, they used some strategies to overcome this deficit. One of nonentrepreneurial experience faculty was Jenifer. It is worth noting that Jenifer was the only faculty from the sample who earned a $\mathrm{PhD}$ in Business Management. However, Jenifer is 
only one example in the study. Yet, her education could become a potential factor that it could be interesting to investigate further.

The matrix presented in Figure 21 has been useful to classify the profile of faculty interviewed as well as to understand what will be the next step to move entrepreneurship teaching forward. The Synthesis cell in matrix from Figure 21 represents the perspective of using a practice-based approach to teaching entrepreneurship. A faculty who uses theory and practice might provide the opportunity to students to practice entrepreneurship using practices that come from relevant theories in entrepreneurship. There is no doubt from entrepreneurship researchers that in order to learn entrepreneurship, students must do and practice entrepreneurship (Fayolle, 2013; Byrne, Fayolle \& Toutain, 2014; Gibb, 2002; Neck \& Green, 2011). However, when it comes to the doing and the practicing "through" entrepreneurship by students, the researchers seem to agree that this does not mean to exclude theory.

Neck et al. (2014) proposed that effectiveness in entrepreneurship teaching requires a set of practices that are grounded in theory, but these theories are invisible for students. The author calls this situation as actionable theory. This approach to teaching entrepreneurship using theory and practice can overcome the situation that Byrne, Fayolle and Toutain (2014) identified as lack of clear use of theorizing and organizing taxonomies in EE. This Synthesis approach, can incorporate into the discussion new theories or emerging theories in EE such as the theory of bricolage (Fisher, 2012) or effectuation theory (Sarasvathy, 2008b) that consider entrepreneurship as an everyday practice (Robinson \& Shumar, 2014) beyond the process of business creation. 
In conclusion, from the results, most faculty who are currently teaching entrepreneurship in Chilean universities from the sample in this study are not adequately informed about pedagogical knowledge and educational theory. This lack of pedagogical knowledge means that even faculty with entrepreneurial experience are not successful in impacting student entrepreneurial intentions. Therefore, this lack of pedagogical theory maybe is a limiting factor to move EE forward in terms of students' entrepreneurial learning.

\section{Discussion}

According to recent entrepreneurship research, entrepreneurship courses have mixed results on student entrepreneurial intentions (Byrne, Fayolle, \& Toutain, 2014). The research in this study echoes those past findings. In this study, as measured by the College Student Survey, the entrepreneurial intentions of Chilean freshmen were not affected by the required entrepreneurship class. The TPB informed the development of the student survey. In this work and reflected in the survey, entrepreneurial intention was defined as an individual psychological construct that demonstrates the intention to start a business. The Likert-scale question items were: "I intend to start a business in the future," "I am looking for opportunities to do business of any kind," "I am figuring out how to start a business" so on (see Appendix B, Section V on College Student Survey).

The survey items suggested that student should envision starting a business to have an entrepreneurial intention. Of course, these items were derived from the TPB that defines entrepreneurial intention in a certain way. I suggest that these survey items may not represent entrepreneurial intention fully. The survey missed the development of skills 
that underlie entrepreneurship like Sergio mentioned. It did not take into account the intra-entrepreneurial characteristics that Jenifer values in her classes. All it asked students to respond to was their interest, ability and knowledge to start a business. The students in this survey are from 18 to 20 years old. They are freshman taking a required course. I argue that the instrument was not as refined as it could have been to capture what students learned about entrepreneurship in these required courses. The survey should more closely match what was taught in the classes.

Future research should address the issue of whether the TPB is an appropriate model to measure effectiveness of entrepreneurship classes as an educational outcome. The TPB may be not the best theory to measure and predict the relationship between the intention (state of mind) and the entrepreneurial behavior (acting on entrepreneurial activities). Intention is not equivalent to behavior and research aimed at better understanding the role of entrepreneurial intention could address the link between intention and behavior (Fayolle \& Gailly, 2015). Also, if the goal of the entrepreneurship class is to help students gain entrepreneurial skills beyond the intention to start a business, then, the better way to measure impact could be look a set of appropriate entrepreneurial skills instead of the global entrepreneurial intention found in the survey.

\section{Implications}

This research study has several implications for the teaching practice of entrepreneurship educators as well as for program developers in EE within universities. Faculty interviewed for the study tended to be uninformed about the broader pedagogical research and frameworks of EE as a field. This suggests that entrepreneurship educators 
might benefit from having deeper understanding of what it means to teach entrepreneurial competencies and skills in a university context. Entrepreneurship faculty could know and use more concepts supporting students' entrepreneurial learning, the development of entrepreneurial competencies and the methods used to assess students effectively (Middleton \& Donnellon, 2013).

The findings of this study also suggest that faculty entrepreneurship experience alone may not be enough to have an impact on student entrepreneurial intentions as measured by the survey. In fact, the results suggest the opposite. Faculty who had experience as entrepreneurs had a mixed and negative effect on student entrepreneurial intentions. Those who had no entrepreneurial experience had a greater effect on student $\mathrm{E}$ intention. This runs counter to common sense and prevailing wisdom that faculty who teach entrepreneurial classes should have experience starting and running a business. Yet, it appears that those with greater entrepreneurial experience had a mixed and negative effect on student E intentions.

How do I explain this finding about the relationship between faculty experience as entrepreneurs and student E intention? First of all, as I have mentioned above the measure of student $\mathrm{E}$ intention may be flawed. In addition, the students who took the measure are young, freshmen, and it is a required class. These two conditions do not seem to foster a positive response to the idea of changing, or even envisioning changing behavior, and becoming an entrepreneur. This finding suggests even another interpretation. Maybe there is something different about the faculty members who have little or no entrepreneurial experience and yet have an effect on student entrepreneurial 
intentions. When I look at the much smaller subset of faculty $(n=8)$ who were interviewed, I have some clues about what the no entrepreneurial experience faculty are doing. Jenifer, for example, has a broader definition of $\mathrm{E}$ that includes not just being a profit-driven entrepreneur, but includes intra-preneurship. Also, she has a variety of activities in her classes and speaks of her class as "fun." Much of this work implies that faculty could learn from the field of education about theoretical frameworks, learning theories, and pedagogical methods such as the experiential learning theory, and the learning styles of individuals to improve their teaching of EE (Kolb, 1984; Neck \& Greene, 2011). As recent research on EE argues, incorporating theories from the field of education into entrepreneurship teaching could be a strategy to connect these fields, which have been disconnected (Fayolle, 2013; Fayolle \& Gailly, 2015). For instance, the concepts of teaching methods like the idea of process-oriented and action-oriented teaching (Béchard \& Grégoire, 2005) could be useful to align the learning goals that faculty want to pursue in their classes and the learning needs of the students. Understanding and deliberately using teaching models will help entrepreneurship educators enhance the coherence between the learning goals, contents, and methods in EE (Fayolle \& Gailly, 2015).

Moreover, the entrepreneurship literature focuses on the development of an entrepreneurial mindset and entrepreneurial thinking (Sarasvathy, 2008a; 2008b). Yet, the faculty interviewed were largely unaware of this valuable literature. Educators in entrepreneurial education (EE) would benefit from learning about entrepreneurship literature to design content and methods that incorporates emerging theories in 
entrepreneurship into their teaching practice, such as the effectuation theory or bricolage (Fisher, 2012), which focuses on developing skills instead of starting businesses. For instance, I suggest that entrepreneurship faculty (including adjunct faculty, instructors, professors, and educators) should receive training not only in how to teach entrepreneurship using practice-based approaches or emerging entrepreneurship theories, but also that they should learn about how students learn about entrepreneurship in general (Cope, 2005; Sanchez, 2011). Collaboration between researchers, educators, and program developers in entrepreneurship within the university will help us to identify the most useful research issues to investigate as well as to improve the design of entrepreneurship courses in terms of content and pedagogies.

Results from this study show that, as a group, educators are currently teaching the type of EE that is learning "for" entrepreneurship using a process-oriented approach (citation). Learning "for" entrepreneurship means that students acquire skills in the use of techniques and in the analysis of business situations and in the synthesis of action plans to develop self-confidence and capacity to start-up companies (Fayolle, 2013; Fisher, 2012, Kozlinska, 2012; Mwasalwiba, 2010). Under the learning "for" entrepreneurship type of EE, entrepreneurship is a broad concept that implies professional and practical dimensions (know what, know how, and know who) of the business creation process.

To help EE move forward, educators might move toward the framework of learning "through" entrepreneurship that considers entrepreneurship as a process of creation and action (Neck \& Greene, 2011). Also, this type of EE incorporates the development of enterprising or entrepreneurial attitudes and skills (know why and know 
when). In other words, learning "through" entrepreneurship means that students learn to become enterprising entrepreneurial individuals in ways that go beyond the start-up process (Sarasvathy, 2008a, 2008b). This implies that practice should use real problems and social issues to develop business plans instead of doing business plans in simulated environments. Educators could encourage students go to their communities and surroundings to find, discover, or create opportunities to solve communities issues (Neck \& Greene).

Indeed, in tune with Fayolle's (2013) and Neck and Greene (2011) arguments that educators in $\mathrm{EE}$ need to reflect on their practice as researchers and educators, entrepreneurship educators need to take a more critical stance toward improving teaching practices and pedagogies in entrepreneurship. This is especially important given the immense growth and public investment in EE on a global scale. More analysis of and critical reflection on the existing research on EE would be useful to advance the body of knowledge (Byrne et al., 2014). Indeed, some entrepreneurship scholars on teaching and learning postulate that entrepreneurship researchers and educators must strive to create a professional community by sharing the same values and objectives in EE (Fayolle \& Gailly, 2008). As an association or faculty group in EE, this professional community will lead to improved reflection on the field of teaching entrepreneurship and on enhancing students' critical thinking to increase the effectiveness of EEP in universities. As a result, increasing self-reflection of faculty could result in better performance (Fayolle \& Gailly, 2015). 
Several scholars agree that it is through the sense-making and interpretation of the experience that learning happens (Rae \& Carswell, 2000). For example, Cope (2005; 2011) observed that higher level of learning happens based on critical incidents during the entrepreneurial experiences, but those incidents require mentoring and coaching from educators that help the learners to reflect and interpret them as learning experience. This calls attention to the role of the educator in encouraging self-reflection during the learning process.

\section{Recommendations for Future Research}

The results and findings of this MMR study open the doors for a larger research agenda especially in Chilean higher education institutions.

One result was that the TPB (Azjen, 1991) might not be the best way to test the acquisition of entrepreneurial intention and skills, especially in freshmen taking a required course. It would be interesting to research other models proposed in entrepreneurship research that are more focused on student skills and competencies rather than just the intention. These models may be more appropriate for assessing the broader and more effective impact of EE (Carsrud \& Krueger, 1993).

Also, there is great opportunity for further research to examine the extent to which the elements of the teaching model proposed by Fayolle and Gailly $(2008,2015)$ align with student learning outcomes, assessments and classroom pedagogies. An area of research could be to analyze the objectives and learning goals of entrepreneurship classes and their coherence with the pedagogies and assessment of students. 
One limitation of this study is that students were not interviewed. They were surveyed but, as noted above, that survey seems to have been limited in its definition of entrepreneurial intention. This limitation could be overcome by the incorporation of the students' point of views and voices regarding how they changed their perceptions after taking an entrepreneurship class. Initially it might be best to design qualitative studies to capture the variety of ways student E intention, skills and dispositions are developed in the class. How do they see EE? How do they perceive it as a tool that allows them to develop other skills necessary for their professional future? Other possible qualitative research could include students' interviews and class observations as well as longitudinal studies to see the impact of EE in long term (over the years in a program) rather than short-term (one semester).

Moreover, it would be very interesting to develop an area of research from the pedagogical perspective, using the effectuation theory (Sarasvathy, 2008a) because this might bring a totally different view on how opportunities are discovered or created. In addition, this research area could focus on how entrepreneurs think and act when they are entrepreneurs. The effectuation theory in EE and teaching is an exciting new area with myriad opportunities for scholarship to move EE toward a type of learning "through" entrepreneurship (Byrne et al., 2014). For example, research might look at questions such as: How should we teach entrepreneurial action using effectuation theory? How should we teach effectuation? How should we teach for an entrepreneurial mind or entrepreneurial thinking? Such questions could help us understand which pedagogies are 
effective in teaching students to think and act like entrepreneurs (Robinson \& Shumar, 2014).

Additional research on entrepreneurial learning and how student best learn in EE is needed (Fayolle, Pittaway, Politis, \& Toutain, 2014). Specifically, some have suggested that researchers design qualitative studies on some of the particular types of learning such as learning from failure in EE (Cope, 2011) and the use of experiential learning (Kolb, Boyatzis, \& Mainemelis, 2001). We also need research that explores the different learning contexts within university settings. For instance, how can EE research be more helpful in improving our understanding of the concepts of entrepreneurship learning and entrepreneurial competencies? How can educators enable entrepreneurial learning and entrepreneurial competencies in the classrooms and outside?

Finally, this study also opens a number of research paths about entrepreneurship as a competence-model of teaching. For example, future research could look at what types of entrepreneurial competencies students develop or enhance during an entrepreneurship class or training. It would be useful for future research to provide a deeper, richer analysis of the pertinent entrepreneurial competencies defined as relevant to developing entrepreneurial thinking and acting.

\section{Final Thoughts}

EE is at the crossroads of entrepreneurship research and the field of education. This intersection is one of the main reasons why I pursued a doctorate in the education field. I started this research motivated by a desire to learn more about education and educators in the field of entrepreneurship at the university level. During the period of 
time conducting this research, I have become much more aware of how important are faculty beliefs about teaching, as well as what are some of the most valuable pedagogical tools that faculty use. At the end, I feel more passionate about EE and more interested in learning more details about how we as educators and researchers can improve our practice to impact student learning.

EE is a new area of research in Chile that needs to be developed. In spite of institutional efforts and public policy incentives made by the Chilean government over the last five years regarding entrepreneurship, there is little research in Chile about EE, the overall effectiveness of entrepreneurship programs, and the impact that entrepreneurship courses might have on university students. Most research has focused on the impact of entrepreneurship at the socio-economic level such as the GEM report rather than on educational and pedagogical level such as how entrepreneurship is defined, taught or how to share best practices among universities classrooms.

This research study looked at the faculty perspectives about teaching, faculty experience of entrepreneurship, and the different pedagogies (active versus passive) that might affect students' entrepreneurial intentions. This study found that there was no impact of required entrepreneurship courses on the student entrepreneurial intentions in the immediate term, after finishing the classes. The study showed a reverse and mixed relationship between faculty entrepreneurial experience and the student entrepreneurial intentions. Faculty entrepreneurial experience seems to have a relationship to student entrepreneurial intention but the results are mixed and not in the direction expected. The faculty with no entrepreneurial experience had a greater effect on student entrepreneurial 
intentions than those with experience. Perhaps it is the teaching methodologies and philosophies that had a much greater impact on student intentions than the experience of the faculty. In addition, as noted above, the College Student Survey, informed by the TPB, may be far too limited in its definition of entrepreneurship to capture what students were learning about entrepreneurship in the classes.

The study also showed that the most common teaching perspective among faculty interviewed was the apprenticeship perspective. However, this study found that there is no impact on the student entrepreneurial intentions by the specific faculty teaching perspectives. Again, the survey that measured entrepreneurial intention may have affected these results. While this survey in the secondary data set provides a powerful starting point for studying EE, there is a need for more research that captures the nuances of classroom teaching, such as, the development of skills associated with entrepreneurship.

The findings contribute to the understanding of EE in Chile. Faculty members define EE as more than a process of business creation. Faculty described EE as a life attitude that focuses specifically on the process of developing entrepreneurial skills and competencies. Regarding teaching entrepreneurship among these faculty, this study found that faculty are using the more practical-oriented type of EE that is learning "for" entrepreneurship while also incorporating some elements of learning "through" entrepreneurship-as opposed to the learning "about" entrepreneurship that is more theoretically oriented. In addition, faculty described they are using a mix of different pedagogies and activities to encourage entrepreneurship practice including: generating 
ideas, team building, business planning, and guest speakers. Faculty reported that they are using fewer traditional pedagogies and more active-based pedagogies. However, in most classes students are asked to pretend to be entrepreneurs in simulated environments rather than really being an entrepreneur dealing with a real world problem, which is the core difference between learning "for" and "through" entrepreneurship. Learning "through" entrepreneurship suggests that learning with and in real-life entrepreneurship situations enables students to experience pitching business ideas to real investors, participating in incubators and internships to create products for real clients.

My future mission as a scholar, educator, and agent of change is to continue to connect the network between entrepreneurship educators and researchers in order to move EE forward as a research field in Chile. Moreover, I will participate in networking, associations, and collaborations to address the issues and challenges that EE faces as a field of research including the lack of legitimacy and coherence (Fayolle, 2013). Because teaching entrepreneurship requires a wide range of pedagogical skills, I would like to contribute to the development of the competencies, knowledge, and reflexivity in entrepreneurship educators.

Finally, as a leader and agent of change, I am fully motivated to keep working toward increasing the equity and the quality of the education that we provide to our students in Chile. I am very committed to create the necessary conditions to support entrepreneurship educators in their teaching practice that allow students to become more entrepreneurial, socially responsible, and capable not only of developing and creating 
new ideas to solve social issues but also to be the world citizens that the $21^{\text {st }}$ century demands.

\section{Summary}

Chapter 5 discussed the results and findings from this MMR study and presents major implications for EE and teaching practice. The findings contribute to the understanding of EE in Chilean universities. In addition, this research is one of the first attempts to add information to the community of researchers and practitioners in entrepreneurship in order to improve the state of the art of EE research in Chile. To the best of my knowledge, no studies in Chile have explored EE in terms of how faculty are implementing EE and how they are using the activities and pedagogies with students. Finally, this study was worth doing because now we know more about how faculty are teaching entrepreneurship in universities in Chile as well as how they define EE and what approaches they are using in teaching entrepreneurship. 


\section{REFERENCES}

Ajzen, I. (1991). The theory of planned behavior. Organizational behavior and human decision processes, 50(2), 179-211.

Alberti, F., Sciascia, S., \& Poli, A. (2004, July). Entrepreneurship education: Notes on an ongoing debate. Proceedings of the 14th Annual International Entrepreneurship Conference, University of Napoli Federico II, Italy.

Albornoz, C. (2013). Is business creation the mean or the end of entrepreneurship education? A multiple case study exploring teaching goals in entrepreneurship education. Journal of Technology Management and Innovation, 8(1), 1-10.

Albornoz, C. A. (2011). Exploring the goals, content, and methods of entrepreneurship professors: A multiple case study (Doctoral dissertation). Florida International University, Miami, Florida.

Albornoz, C. A. (2012). The effect of obligatory entrepreneurship education on college students. Santiago, Chile: National Research Funding Competition by the Fund for Scientific \& Technological Development and National Commission for Scientific \& Technological Research.

Albornoz, C. A. (2014). Effect of the entrepreneurship mandatory class on college students: An exploratory research. Santiago, Chile: National Research Funding Competition by the Fund for Scientific \& Technological Development and National Commission for Scientific \& Technological Research.

Alvarez, C., \& Urbano, D. (2011). Environmental factors and entrepreneurial activity in Latin America. Academia Revista Latinoamericana de Administración [Latin American Journal of Management Academy], 48, 31-45.

Alvarez, S. A., \& Barney, J. B. (2013). Epistemology, opportunities, and entrepreneurship: Comments on Venkataraman et al. (2012) and Shane (2012). Academy of Management Review, 38(1), 154-157.

Amorós, J. E., \& Cazenave, C. P. (2011). Global entrepreneurship monitor (GEM) Reporte especial de Chile. Santiago, Chile: Salesianos Impresores S. A. [Global entrepreneurship monitor (GEM) special report].

Arthur, S., Hisrich, R. ., \& Cabrera, A. (2012). The importance of education in the entrepreneurial process: A world view. Journal of Small Business and Enterprise Development, 19(3), 500-514.

Attride-Stirling, J. (2001). Thematic networks: An analytic tool for qualitative research. Qualitative Research, 1(3), 385-405. 
Bae, T. J., Qian, S., Miao, C., \& Fiet, J. O. (2014). The relationship between entrepreneurship education and entrepreneurial intentions: A meta-analytic review. Entrepreneurship Theory and Practice, 38(2), 217-254.

Baker, T., \& Nelson, R. E. (2005). Creating something from nothing: Resource construction through entrepreneurial bricolage. Administrative Science Quarterly, 50(3), 329-366.

Balan, P., \& Metcalfe, M. (2012). Identifying teaching methods that engage entrepreneurship students. Education and Training, 54(5), 368-384.

Bandura, A. (1982). Self-efficacy mechanism in human agency. American Psychologist, 37(2), 122.

Baumol, W. J. (2010). The microtheory of innovative entrepreneurship. Princeton, NJ: Princeton University Press.

Béchard, J. P., \& Grégoire, D. (2005). Entrepreneurship education research revisited: The case of higher education. Academy of Management Learning and Education, 4(1), 22-43.

Bennett, R. (2005). Business lecturers' perceptions of the nature of entrepreneurship. International Journal of Entrepreneurial Behaviour and Research, 12(3), 165-188.

Blenker, P., T. Elmholdt, S., H. Frederiksen, S., Korsgaard, S., \& Wagner, K. (2014). Methods in entrepreneurship education research: A review and integrative framework. Education and Training, 56(8/9), 697-715.

Blenker, P., Frederiksen, S. H., Korsgaard, S., Müller, S., Neergaard, H., \& Thrane, C. (2012). Entrepreneurship as everyday practice: Towards a personalized pedagogy of enterprise education. Industry and Higher Education, 26(6), 417-430.

Bolman, L., \& Deal, T. (2008). Reframing organizations: Artistry, choice and leadership. San Francisco, CA: Jossey-Bass.

Brush, C., Duhaime, I., Gartner, W., Stewart, A., Katz, J., Hitt, M., . . Venkataraman, S. (2003). Doctoral education in the field of entrepreneurship. Journal of Management , 29(3), 309-311.

Byrne, J., Fayolle, A., \& Toutain, O. (2014). 15. Entrepreneurship education: What we know and what we need to know. In E. Chell \& M. Karataş-Özkan (Eds.), Handbook of research on small business and entrepreneurship (pp. 261288). Northampton, MA: Edward Elgar. 
Chia, R. (1996). Teaching paradigm shifting in management education: University business schools and the entrepreneurial imagination. Journal of Management Studies, 33(4), 40.

Collins, J. B., \& Pratt, D. D. (2011). The teaching perspectives inventory at 10 years and 100,000 respondents reliability and validity of a teacher self-report inventory. Adult Education Quarterly, 61(4), 358-375.

Comisión Nacional de Investigación Científica y Tecnológica (CONICYT) [National Commission for Scientific and Technological Research]. (2014). Basic information. Retrieved December 14, 2014, from http://www.conicyt.cl

Consejo Nacional de Educación, (CNED) [National Education Council, Chile]. (2015). Basic information. Retrieved May 1, 2015, from http://www.cned.cl

Conti, G. J. (2004). Identifying your teaching style. In M. W. Galbraith (Ed.), Adult learning methods: A guide for effective instruction ( ${ }^{\text {rd }}$ ed.; pp. 75-92). Malabar, FL: Krieger.

Cope, J. (2005). Toward a dynamic learning perspective of entrepreneurship. Entrepreneurship Theory and Practice, 29(4), 373-397.

Cope, J. (2011). Entrepreneurial learning from failure: An interpretative phenomenological analysis. Journal of Business Venturing, 26(6), 604-623.

Corbett, A. C. (2005). Experiential learning within the process of opportunity identification and exploitation. Entrepreneurship Theory and Practice, 29(4), 473-491.

Creswell, J. W. (2014a). A concise introduction to mixed methods research. Thousand Oaks, CA: Sage.

Creswell, J. W. (2014b). Research design: Qualitative, quantitative, and mixed methods approaches. Thousand Oaks, CA: Sage.

Creswell, J. W., \& Plano Clark, V. L. (2011). Designing and conducting mixed methods research $\left(2^{\text {nd }}\right.$ ed.). Thousand Oaks, CA: Sage.

Duarte, F. P. (2013). Conceptions of good teaching by good teachers: Case studies from an Australian university. Journal of University Teaching and Learning Practice, 10(1), 1-15.

Farashah, A. D. (2013). The process of impact of entrepreneurship education and training on entrepreneurship perception and intention: Study of educational system of Iran. Education and Training, 55(8/9), 868-885. 
Fayolle, A. (2007). Handbook of research in entrepreneurship education: A general perspective (Vol. 1-2). Chentenham, England: Edward Elgar.

Fayolle, A. (2013). Personal views on the future of entrepreneurship education. Entrepreneurship and Regional Development, 25(7-8), 692-701.

Fayolle, A., \& Gailly, B. (2008). From craft to science teaching models and learning process in entrepreneurship education. Journal of European Industrial Training, 32(7), 569-593.

Fayolle, A., \& Gailly, B. (2015). The impact of entrepreneurship education on entrepreneurial attitudes and intention: Hysteresis and persistence. Journal of Small Business Management, 53(1), 75-93.

Fayolle, A., Gailly, B., \& Lassas-Clerc, N. (2006a). Assessing the impact of entrepreneurship education programmes: A new methodology. Journal of European Industrial Training, 30(9), 701-720.

Fayolle, A., Gailly, B., \& Lassas-Clerc, N. (2006b). Effect and counter-effect of entrepreneurship education and social context on student's intentions. Estudios de Economía Aplicada [Applied Economic Studies], 24(2), 509-523

Fayolle, A., \& Liñán, F. (2013). The future of research on entrepreneurial intentions. Journal of Business Research, 67(5), 663-666.

Fayolle, A., \& Toutain, O. (2013). Four educational principles to rethink ethically entrepreneurship education. Revista de Economía Mundial [Journal of World Economy], 35, 165-176.

Fayolle, A., \& Wright, M. (Eds.). (2014). How to get published in the best entrepreneurship journals: A guide to steer your academic career. Northampton, MA: Edward Elgar.

Feilzer, M. Y. (2010). Doing mixed methods research pragmatically: Implications for the rediscovery of pragmatism as a research paradigm. Journal of Mixed Methods Research, 4(1), 6-16. doi:10.1177/1558689809349691

Field, A. (2009). Discovering statistics using SPSS ( ${ }^{\text {rd }}$ ed.), London, England: Sage.

Fiet, J. (2001). The pedagogical side of entrepreneurship theory. Journal of Business Venturing, 16(2), 101-117.

Fink, L. (2003). Creating significant learning experiences: An integrated approach to designing college courses. San Francisco, CA: Jossey-Bass. 
Fisher, G. (2012). Effectuation, causation, and bricolage: A behavioral comparison of emerging theories in entrepreneurship research. Entrepreneurship Theory and Practice, 36(5), 1019-1051.

Gibb, A. (1993). Enterprise culture and education: Understanding enterprise education and its links with small business, entrepreneurship and wider educational goals. International Small Business Journal, 11(3), 11-34.

Gibb, A. (1996). Entrepreneurship and small business management: Can we afford to neglect them in the twenty-first century business school? British Journal of Management, 7(4), 309-321.

Gibb, A. (2002). In pursuit of a new enterprise and entrepreneurship paradigm for learning: Creative destruction, new values, new ways of doing things and new combinations of knowledge. International Journal of Management Reviews, 4(3), 233-269.

Greenberg, D., McKone-Sweet, K., \& Wilson, H. J. (2011). The new entrepreneurial leader: Developing leaders who shape social and economic opportunity. San Francisco, CA: Berrett-Koehler.

Griffiths, M., Kickul, J., Bacq, S., \& Terjesen, S. (2012). A Dialogue with William J. Baumol: Insights on entrepreneurship theory and education. Entrepreneurship Theory and Practice, 36(4), 611-625.

Haase, H., \& Lautenschläger, A. (2011). The teachability dilemma of entrepreneurship. International Entrepreneurship and Management Journal, 7(2), 145-162.

Hamidi, D. Y., Wennberg, K., \& Berglund, H. (2008). Creativity in entrepreneurship education. Journal of Small Business and Enterprise Development, 15(2), 304-320.

Hannon, P. (2006). Teaching pigeons to dance: Sense and meaning in entrepreneurship education. Education and Training, 48(5), 296-308.

Harrits, G. S. (2011). More than method?: A discussion of paradigm differences within mixed methods research. Journal of Mixed Methods Research, 5(2), 150-166.

Heinonen, J., \& Poikkijoki, S. (2006). An entrepreneurial-directed approach to entrepreneurship education: Mission impossible? The Journal of Management Development, 25(1), 80-94

Henry, C., Hill, F., \& Leitch, C. (2005). Entrepreneurship education and training: Can entrepreneurship be taught? Part I. Education and Training, 47(2), 98-111. 
Hindle, K. (2007). Teaching entrepreneurship at university: From the wrong building to the right philosophy. In A. Fayolle (Ed.), Handbook of research in entrepreneurship education (Vol. 1; pp. 104-126). Cheltenham, England: Edward Elgar.

Ivankova, N. V., Creswell, J. W., \& Stick, S. L. (2006). Using mixed-methods sequential explanatory design: From theory to practice. Field Methods, 18(1), 3-20.

Johnson, R. B., \& Onwuegbuzie, A. J. (2004). Mixed methods research: A research paradigm whose time has come. Educational researcher, 33(7), 14-26.

Jones, B., \& Iredale, N. (2010). Enterprise education as pedagogy. Education and Training, 52(1), 7-19.

Kantis, H. (2008). Aportes para el diseño de programas nacionales de desarrollo emprendedor en América Latina [Contributions to the design of national entrepreneur development programs in Latin America]. Retrieved from http://services.iadb.org/wmsfiles/products/Publications/35166775.pdf

Katz, J. (2003). The chronology and intellectual trajectory of American entrepreneurship education: 1876-1999. Journal of Business Venturing , 18(2), 283-300.

Katz, J. (2008). Fully mature but not fully legitimate: A different perspective on the state of entrepreneurship education. Journal of Small Business Management , 46(4), $550-556$.

Kember, D. (1997). A reconceptualisation of the research into university academics' conceptions of teaching. Learning and Instruction, 7(3), 255-275.

Kirby, D. A. (2004). Entrepreneurship education: Can business schools meet the challenge. Education and Training , 46(8/9), 510-519.

Kirzner, I. M. (1978). Competition and entrepreneurship. Chicago, IL: University of Chicago Press.

Kirzner, I. M. (1979). Perception, opportunity, and profit: Studies in the theory of entrepreneurship. Chicago, IL: University of Chicago Press.

Klinger, B., \& Schündeln, M. (2011). Can entrepreneurial activity be taught? Quasiexperimental evidence from Central America. World Development, 39(9), 15921610.

Kolb, D. A. (1984). Experiential learning: Experience as the source of learning and development (Vol. 1). Englewood Cliffs, NJ: Prentice-Hall. 
Kolb, D. A., Boyatzis, R. E., \& Mainemelis, C. (2001). Experiential learning theory: Previous research and new directions. In R. J. Sternberg \& J. Zhang (Eds.), Perspectives on Thinking, Learning, and Cognitive Styles (pp. 193-210). Mahwah, NJ: Lawrence Erlbaum.

Kozlinska, I. (2011). Contemporary approaches to entrepreneurship education. Journal of Business Management, (4), 205-220.

Krathwohl, D. R. (1993). Methods of educational and social science research: An integrated approach. New York, NY: Longman/Addison Wesley.

Krueger, N. F. (2007). What lies beneath? The experiential essence of entrepreneurial thinking. Entrepreneurship Theory and Practice, 31(1), 123-138.

Krueger, N. F., \& Carsrud, A. L. (1993). Entrepreneurial intentions: Applying the theory of planned behaviour. Entrepreneurship and Regional Development, 5(4), 315-330.

Krueger, N. F., Reilly, M. D., \& Carsrud, A. L. (2000). Entrepreneurial intentions: A competing models approach. Journal of Business Venturing, 15(5/6), 411-432.

Kuratko, D. (2005). The emergence of entrepreneurship education: Development, trends, and challenges. Entrepreneurship: Theory and Practice, 29(5), 577-598.

Kwon, S. W., \& Arenius, P. (2010). Nations of entrepreneurs: A social capital perspective. Journal of Business Venturing, 25(3), 315-330.

Kyro, P. (2007). A theoretical framework for teaching and learning entrepreneurship. International Journal of Business and Globalization, 2(1), 39-55.

Lautenschläger, A., \& Haase, H. (2011). The myth of entrepreneurship education: Seven arguments against teaching business creation at universities. Journal of Entrepreneurship Education, 14(1), 147-161.

Lepeley, M. T., \& Albornoz, C. (2012) Business education in Chile: Advancing to the $21^{\text {st }}$ century people centered-innovation based entrepreneurial "mega trend." Retrieved from http://mba.americaeconomia.com/biblioteca/papers/businesseducation-chile-advancing-21st-century-people-centered-innovation-based-e

Lima, E., Lopes, R. M., Nassif, V., \& Silva, D. (2015). Opportunities to improve entrepreneurship education: Contributions considering Brazilian challenges. Journal of Small Business Management, 53(4), 1033-1051.

Löbler, H. (2006). Learning entrepreneurship from a constructivist perspective. Technology Analysis AND Strategic Management, 18(1), 19-38. 
Lorz, M., Mueller, S., \& Volery, T. (2013). Entrepreneurship education: A systematic review of the methods in impact studies. Journal of Enterprising Culture, 21(2), 123-151.

Maguire, M., \& Lunati, M. (2009). Evaluation of programmes concerning education for entrepreneurship: Report by the OECD Working Party on SMEs and Entrepreneurship, OECD. Paris, France: Organization for Economic Co-operation and Development.

Mäkimurto-Koivumaa, S., \& Puhakka, V. (2013). Effectuation and causation in entrepreneurship education. International Journal of Entrepreneurial Venturing, $5(1), 68-83$.

Maritz, A., \& Brown, C. R. (2013). Illuminating the black box of entrepreneurship education programs. Education and Training, 55(3), 234-252.

Mars, M ., \& Rios-Aguilar, C. (2010). Academic entrepreneurship (re)defined: Significance and implications for the scholarship of higher education. Journal of Higher Education , 59(4), 441-460.

Martin, B. C., McNally, J. J., \& Kay, M. J. (2013). Examining the formation of human capital in entrepreneurship: A meta-analysis of entrepreneurship education outcomes. Journal of Business Venturing, 28(2), 211-224.

Martínez, A. C., Levie, J., Kelley, D. J., Sæmundsson, R. J., \& Schøtt, T. (2010). Global entrepreneurship monitor special report (2008): A global perspective on entrepreneurship education and training. London, England: Global Entrepreneurship Research Association.

Matlay, H. (2006). Researching entrepreneurship and education. Part 2: What is entrepreneurship education and does it matter? Education and Training, 48(8/9), 704-718.

Matlay, H. (2010). Introduction: Contemporary perspectives on entrepreneurship education and training. Journal of Small Business and Enterprise Development, 17(4). Retrieved from http://dx.doi.org/10.1108/jsbed.2010.27117daa.001

Mayhew, M. J., Simonoff, J. S., Baumol, W. J., Wiesenfeld, B. M., \& Klein, M. W. (2012). Exploring innovative entrepreneurship and its ties to higher educational experiences. Research in Higher Education, 53(8), 831-859.

McMullan, W.E., \& Long, W.A. (1987). Entrepreneurship education in the nineties. Journal of Business Venturing, 2, 261-275. 
Mejoramiento de la Calidad en Educación Superior Chile (MECESUP) [Quality Improvement in Higher Education Chile]. (2015). Retrieved June 10, 2015, from http://www.mecesup.cl

Merriam, S. B. (2009). Qualitative research: A guide to design and implementation. San Francisco, CA: John Wiley \& Sons.

Mertens, D. M. (2012). What comes first? The paradigm or the approach? Journal of Mixed Methods Research, 6(4), 255-257. doi:10.1177/1558689812461574

Mertens, D. M. (2010). Philosophy in mixed methods teaching: The transformative paradigm as illustration. International Journal of Multiple Research Approaches, 4(1), 9-18.

Middleton, W. K., \& Donnellon, A. (2014). Personalizing entrepreneurial learning: A pedagogy for facilitating the know why. Entrepreneurship Research Journal, 4(2), 167-204.

Middleton, W. K., Mueller, S., Blenker, P., Neergaard, H., \& Tunstall, R. (2014, November ). Experience-based learning in entrepreneurship education: A comparative study of four programmes in Europe. Research in Entrepreneurship and Small Business, ) 28, 1-15. Retrieved from http://publications.lib.chalmers.se/ records/fulltext/203607/local_203607.pdf

Ministerio de Educación - Gobierno de Chile (MINEDUC) [Ministry of Education of Chile]. (2014). Directory of Higher Education Institutions. Retrieved January 24, 2014, from http://www.mineduc.cl

Molina-Azorín, J. F., López-Gamero, M. D., Pereira-Moliner, J., \& Pertusa-Ortega, E. M. (2012). Mixed methods studies in entrepreneurship research: Applications and contributions. Entrepreneurship and Regional Development, 24(5-6), 425-456.

Morgan, D. L. (2007). Paradigms lost and pragmatism regained methodological implications of combining qualitative and quantitative methods. Journal of Mixed Methods Research, 1(1), 48-76.

Morgan, D. L. (2013). Integrating qualitative and quantitative methods. Thousand Oaks, CA: Sage.

Mueller, S. (2011). Increasing entrepreneurial intention: Effective entrepreneurship course characteristics. International Journal of Entrepreneurship and Small Business, 13(1), 55-74.

Mwasalwiba, E. (2010). Entrepreneurship education: A review of its objectives, teaching methods, and impact indicators. Education and Training, 52(1), 20-47. 
Nabi, G., \& Liñán, F. (2011). Graduate entrepreneurship in the developing world: Intentions, education and development. Education and Training, 53(5), 325-334.

Neck, H ., \& Greene, P. (2011). Entrepreneurship education: Known worlds and new frontiers. Journal of Small Business Management, 49(1), 55-70.

Neck, H. M., Greene, P. G., \& Brush, C. G. (Eds.). (2014). Teaching entrepreneurship: A practice-based approach. Northampton, MA: Edward Elgar.

Norton, L., Richardson, T. E., Hartley, J., Newstead, S., \& Mayes, J. (2005). Teachers' beliefs and intentions concerning teaching in higher education. Higher Education, 50(4), 537-571.

O'Connor, A. (2012). A conceptual framework for entrepreneurship education policy: Meeting government and economic purposes. Journal of Business Venturing. doi:10.1016/j.jbusvent.2012.07.003

Oosterbeek, H., van Praag, M., \& Ijsselstein, A. (2010). The impact of entrepreneurship education on entrepreneurship skills and motivation. European Economic Review, 54(3), 442-454.

Perry, J. T., Chandler, G. N., \& Markova, G. (2012). Entrepreneurial effectuation: A review and suggestions for future research. Entrepreneurship Theory and Practice, 36(4), 837-861.

Pittaway, L., \& Cope, J. (2007a). Entrepreneurship education a systematic review of the evidence. International Small Business Journal, 25(5), 479-510.

Pittaway, L., \& Cope, J. (2007b). Simulating entrepreneurial learning integrating experiential and collaborative approaches to learning. Management Learning, $38(2), 211-233$.

Pittaway, L., \& Edwards, C. (2012). Assessment: Examining practice in entrepreneurship education. Education and Training, 54(8/9), 778-800.

Plaschka, G ., \& Welsch, H. (1990). Emerging structures in entrepreneurship education: Curriculum designs and strategies. Entrepreneurship Theory and Practice, 14(3), $55-71$.

Politis, D. (2005). The process of entrepreneurial learning: A conceptual framework. Entrepreneurship theory and practice, 29(4), 399-424.

Potter, J. (Ed.). (2008). Local economic and employment development (LEED). Entrepreneurship and higher education. Paris, France: Organization for Economic Co-operation and Development. 
Pratt, D. D., \& Collins, J. B. (2000, February). The teaching perspectives inventory (TPI). Paper presented at the Adult Education Research Conference, Vancouver, BC. Retrieved from http://www.teachingperspectives.com/tpi/

Pratt, D. D., Collins, J. B., \& Selinger, S. J. (2001, April 10-14). Development and use of the teaching perspectives inventory (TPI). Paper presented at the annual meeting of the American Educational Research Association, Seattle, WA.

Pratt, D. D. (1998). Five perspectives on teaching in adult and higher education. Melbourne, FL: Krieger.

Pratt, D. D. (2005). Personal philosophies of teaching: A false promise? ACADEME, 91, 32-36.

Rae, D. (2005). Entrepreneurial learning: A narrative-based conceptual model. Journal of Small Business and Enterprise Development, 12(3), 323-335.

Rae, D., \& Carswell, M. (2001). Towards a conceptual understanding of entrepreneurial learning. Journal of Small Business and Enterprise Development, 8(2), 150-158.

Read, S., \& Sarasvathy, S. (2005). Knowing what to do and doing what you know: Effectuation as a form of entrepreneurial expertise. The Journal of Private Equity, 9(1), 45-62.

Reynolds, P. D. (2007). Entrepreneurship in the United States: The future is now (Vol. 15). Retrieved from http://www.springer.com/us/book/9780387456676

Robinson, S., \& Shumar, W. (2014). Ethnographic evaluation of entrepreneurship education in higher education: A methodological conceptualization. The International Journal of Management Education, 12(3), 422-432.

Ruskovaara, E., \& Pihkala, T. (2013). Teachers implementing entrepreneurship education classroom practices. Education and Training, 55(2), 7-25.

Saldaña, J. (2012). The coding manual for qualitative researchers (No. 14). Thousand Oaks, CA: Sage.

Sánchez, J. C. (2011). University training for entrepreneurial competencies: Its impact on intention of venture creation. International Entrepreneurship and Management Journal, 7(2), 239-254.

Sánchez, J. C. (2013). The impact of an entrepreneurship education program on entrepreneurial competencies and intention. Journal of Small Business Management, 51(3), 447-465. 
Sarasvathy, S., \& Venkataraman, S. (2011). Entrepreneurship as method: Open questions for an entrepreneurial future. Entrepreneurship Theory and Practice, 35(1), 113-135.

Sarasvathy, S. (2008a). Effectuation: Elements of entrepreneurial expertise. Northampton, MA: Edward Elgar.

Sarasvathy, S. (2008b). What makes entrepreneurs entrepreneurial? Retrieved from http://www.effectuation.org/sites/default/files/documents/what-makesentrepreneurs-entrepreneurial-sarasvathy.pdf

Schön, D. A. (1983). The reflective practitioner: How professionals think in action (Vol. 5126). New York, NY: Basic Books.

Schön, D. A. (1987). Educating the reflective practitioner. San Francisco, CA: JosseyBass.

Schumpeter, J. A. (1934). The theory of economic development: An inquiry into profits, capital, credit, interest, and the business cycle. Urbana, IL: University of Illinois at Urbana-Champaign's Academy for Entrepreneurial Leadership Historical Research Reference in Entrepreneurship. Retrieved from http://ssrn.com/ abstract $=1496199$

Seelig, T. (2015). Insight out: Get ideas out of your head and into the world. New York, NY: Harper Collins.

Seikkula-Leino, J., Satuvuori, T., Ruskovaara, E., \& Hannula, H. (2015). How do Finnish teacher educators implement entrepreneurship education? Education and Training, 57(4), 392-404.

Shane, S., \& Venkataraman, S. (2000). The promise of entrepreneurship as a field of research. Academy of Management Review, 25(1), 217-226.

Sirelkhatim, F., \& Gangi, Y. (2015). Entrepreneurship education: A systematic literature review of curricula contents and teaching methods. Cogent Business and Management, 2(1). Retrieved from http://www.tandfonline.com/doi/pdf/ $10.1080 / 23311975.2015 .1052034$

Sistema de Investigación Educación Superior Chile (SIES) [Higher Education Research System Chile]. (2015). Retrieved February 25, 2015, from http://www.sies.cl

Solomon, G. T., Duffy, S., \& Tarabishy, A. (2002). The state of entrepreneurship education in the United States: A nationwide survey and analysis. International Journal of Entrepreneurship Education, 1(1), 65-86. 
Solomon, G. T., Weaver, K. M., \& Fernald, L. W. (1994). A historical examination of small business management and entrepreneurship pedagogy. Simulation and Gaming, 25(3), 338-352.

Stentz, J. E., Plano Clark, V. L., \& Matkin, G. S. (2012). Applying mixed methods to leadership research: A review of current practices. The Leadership Quarterly, 23(6), 1173-1183.

Taatila, V. (2010). Learning entrepreneurship in higher education. Education and Training, 52(1), 48-61.

Tounés, A., Lassas-Clerc, N., \& Fayolle, A. (2014). Perceived entrepreneurial competences tested by business plan pedagogies. International Journal of Entrepreneurship and Small Business, 21(4), 541-557.

Venkataraman, S. (1997). The distinctive domain of entrepreneurship research: An editor's perspective. Advances in entrepreneurship, firm emergence, and growth, 3, 119-138.

Venkataraman, S., Sarasvathy, S. D., Dew, N., \& Forster, W. R. (2012). Reflections on the 2010 AMR decade award: Whither the promise? Moving forward with entrepreneurship as a science of the artificial. Academy of Management Review, 37(1), 21-33.

Vesper, K., \& Gartner, W. (1997). Measuring progress in entrepreneurship education. Journal of Business Venturing, 12, 403-421.

Volkmann, C., Wilson, K. E., Marlotti, S., Rabuzzi, D., Vyakarnam, S., \& Sepulveda, A. (2009). Educating the next wave of entrepreneurs: Unlocking entrepreneurial capabilities to meet the global challenges of the $21^{\text {st }}$ century. A report of the global education initiative. Retrieved from http://www.weforum.org/pdf/GEI/ 2009/Entrepreneurship_Education_Report.pdf

Von Graevenitz, G., Harhoff, D., \& Weber, R. (2010). The effects of entrepreneurship education. Journal of Economic Behavior and Organization, 76(1), 90-112.

Von Kortzfleisch, H. F., Zerwas, D., \& Mokanis, I. (2013). Potentials of entrepreneurial design thinking® for entrepreneurship education. Procedia-Social and Behavioral Sciences, 106, 2080-2092.

Wang, C. L., \& Chugh, H. (2014). Entrepreneurial learning: Past research and future challenges. International Journal of Management Reviews, 16(1), 24-61.

Winkel, D. (2013). The changing face of entrepreneurship education. Journal of Small Business Management, 51(3), 313-314. 
World Bank. (2013). Doing business 2013: Smarter regulations for small and mediumsize enterprises. Washington, DC: World Bank Group. Retrieved from http://www.doingbusiness.org/reports/global-reports/doing-business-2013

Xavier, S. R., Kelley, D., Kew, J., Herrington, M., \& Vorderwülbecke A. (2013). Global entrepreneurship monitor: Global report 2012. London, England: Global Entrepreneurship Research Association

Zhao, Y. (2012). World class learners: Educating creative and entrepreneurial students. SAGE. 
APPENDIX A

SUMMARY OF FIVE PERSPECTIVES ON GOOD TEACHING

\begin{tabular}{|c|c|}
\hline PERSPECTIVE & EXPLANATION OF GOOD TEACHING \\
\hline TRANSMISSION & $\begin{array}{l}\text { Effective teaching requires a substantial commitment to the } \\
\text { content or subject matter. } \\
\text { From a transmission perspective, effective teaching assumes } \\
\text { instructors will have the mastery over their content. Those who } \\
\text { see transmission as their dominant perspective are committed, } \\
\text { sometimes passionately, to their content or subject matter. They } \\
\text { believe their content is a relatively well-defined and stable body } \\
\text { of knowledge and skills. It is the learners' responsibility to } \\
\text { master their content. The instructional process is shaped and } \\
\text { guided by the content. It is the teacher's primary responsibility } \\
\text { to present the content accurately and efficiently to learners. }\end{array}$ \\
\hline APPRENTICESHIP & $\begin{array}{l}\text { Effective teaching is a process of socializing students into } \\
\text { new behavioral norms and ways of working. } \\
\text { From apprenticeship perspective, effective teaching assumes } \\
\text { that instructors will be experienced practitioners of what they } \\
\text { are teaching. Those who hold apprenticeship as their dominant } \\
\text { perspective are committed to having learners observe then in } \\
\text { action, doing, what it is that leaners must learn. They believe, } \\
\text { rather passionately, that teaching and learning are most effective } \\
\text { when people are working on authentic tasks in real settings of } \\
\text { application or practice. Therefore, the instructional process is } \\
\text { often a communication of demonstration, observation and } \\
\text { guided practice, with leaners gradually, with learners gradually } \\
\text { doing more and more of the work. }\end{array}$ \\
\hline DEVELOPMENTAL & $\begin{array}{l}\text { Effective teaching must be planned and conducted from the } \\
\text { learner's point of view. } \\
\text { From a developmental perspective, effective teaching begins } \\
\text { with the learners' prior knowledge of the content and skills to be } \\
\text { learned. Instructors holding a developmental dominant } \\
\text { perspective are committed to restructuring how people think } \\
\text { about the content. They believe in the emergence of } \\
\text { increasingly complex and sophisticated cognitive structures } \\
\text { related to thinking about the content. The key to changing those } \\
\text { structures lies in a combination of effective questioning and } \\
\text { 'bridging' knowledge the challenges learners to move from } \\
\text { relatively simple to more complex forms of thinking. }\end{array}$ \\
\hline NURTURING & $\begin{array}{l}\text { Effective teaching assumes that long-term, hard, persistent } \\
\text { effort to achieve comes from the heart, not the head. }\end{array}$ \\
\hline
\end{tabular}




\begin{tabular}{l|l}
\hline & $\begin{array}{l}\text { From a nurturing perspective, effective teaching must respect } \\
\text { the leaner's self-concept and self-efficacy. Instructors holding } \\
\text { nurturing as their dominant perspective care deeply about their } \\
\text { learners, working to support effort as much as achievement. } \\
\text { They are committed to the whole person and certainly not just } \\
\text { the intellect of the learner. They believe passionately, that } \\
\text { anything that threatens the self-concept interferes with learning. } \\
\text { Therefore, their teaching always strives for a balance between } \\
\text { challenging people to do their best, while supporting and } \\
\text { nurturing their efforts to be successful. }\end{array}$ \\
\hline SOCIAL REFORM & $\begin{array}{l}\text { Effective teaching seeks to change society in substantive } \\
\text { ways. } \\
\text { From a social reform perspective, effective teaching is the } \\
\text { pursuit of social change more than individual learning. } \\
\text { Instructors holding social reform as their dominant perspective } \\
\text { are deeply committed to social issues and structural changes in } \\
\text { society. Both content and learners are secondary to large-scale } \\
\text { change in society. Instructors are clear and articulate about what } \\
\text { changes must take place, and their teaching as an instrument of } \\
\text { social change. Even when teaching, their professional identity is } \\
\text { as an advocate for the changes they wish to bring about in } \\
\text { society. }\end{array}$ \\
2000.
\end{tabular}

Source: Pratt \& Collins, 2000. 


\section{APPENDIX B}

\section{SURVEY STUDENTS (ENGLISH)}

\section{INFORMED CONSENT}

You have been invited to participate in a study of the "effects of a required course in the entrepreneurship intention." The aim of this study is to determine the effect that a required course in entrepreneurship has on students' entrepreneurial intentions. Your participation consists in answering questions in a survey at the beginning and end of their course that you are taking. The survey will take approximately 20 minutes to answer. All information collected will be confidential and will not be used for any other purpose outside of this research. Responses to the questionnaire will be coded using an identification number and will be handled anonymously. This information will not be known by people other than the researcher or the person in charge of the research data. You may refuse to answer any questions and may withdraw your participation in the study at any time you want. If you have any questions about this project, you can ask questions at any time during your participation. This project has the support of FONDECYT. The project No. is 11121458 and is in charge of Dr. Carlos Albornoz (calbronoz@udd.cl), professor of the Faculty of Economics and Business, at Universidad del Desarrollo, Santiago, Chile.

\section{AGREE}

I DISAGREE

II. DEMOGRAFIC DATA (7 Questions)

\section{STUDENT'S NATIONAL IDENTIFICATION NUMBER:}

2. e-mail:

\section{Year or birth:}

4. Gender: Female ___ Male

5. University name:

6. Name of the faculty, professor, instructor of the entreprenuership course:

7. Program in which you are studying:

III. ENTREPRENEURSHIP INTENTION Y ATTITUD (GEM) (3 Preguntas)

8. Are you thinking of starting a new business in the next 12 months? (including any self-employment or selling any goods and / or services to others)

YES NO__ I DO NOT KNOW

9. Do you think you have the knowledge, skills and experience required to start a new business? YES I DO NOT KNOW

10. At the end of your career, in which sector do you see yourself working? (in which sector you would like professionally develop your career?): 
IV. COURSE REJECTION

11. What do you think of the following statements?

\begin{tabular}{|c|c|c|c|c|c|}
\hline \# & QUESTIONS & $\begin{array}{l}\text { Strongly } \\
\text { disagree }\end{array}$ & Disagree & Agree & $\begin{array}{l}\text { Strongly } \\
\text { Agree }\end{array}$ \\
\hline 1 & $\begin{array}{l}\text { I would do not take this course if I } \\
\text { choose (if voluntary) }\end{array}$ & & & & \\
\hline 2 & $\begin{array}{l}\text { This course contributes little to my } \\
\text { training }\end{array}$ & & & & \\
\hline 3 & $\begin{array}{l}\text { I think this course will have little } \\
\text { impact on my entrepreneurial skills }\end{array}$ & & & & \\
\hline 4 & $\begin{array}{l}\text { Taking an entrepreneurship class } \\
\text { early in my college years is a } \\
\text { waste of time }\end{array}$ & & & & \\
\hline 5 & $\begin{array}{l}\text { Learning for entrepreneurship is a } \\
\text { waste of time }\end{array}$ & & & & \\
\hline 6 & $\begin{array}{l}\text { I wish other courses were } \\
\text { required, they would be more } \\
\text { related to my degree }\end{array}$ & & & & \\
\hline 7 & Entrepreneurship cannot be taught & & & & \\
\hline 8 & $\begin{array}{l}\text { It is not necessary taking a course } \\
\text { in entrepreneurship to create a } \\
\text { business }\end{array}$ & & & & \\
\hline 9 & $\begin{array}{l}\text { In general I dislike the required } \\
\text { courses }\end{array}$ & & & & \\
\hline
\end{tabular}

V. ENTREPRENEURIAL INTENTION SCALE

12. What do you think of the following statements regarding the intention to start a business?

\begin{tabular}{|l|l|l|l|l|l|l|l|l|}
\hline$\#$ & Questions & $\begin{array}{l}\text { Absolutel } \\
\text { y false }\end{array}$ & False & $\begin{array}{l}\text { Slightly } \\
\text { false }\end{array}$ & $\begin{array}{l}\text { Neither } \\
\text { true } \\
\text { nor } \\
\text { false }\end{array}$ & $\begin{array}{l}\text { Some } \\
\text { Truth }\end{array}$ & True & $\begin{array}{l}\text { Absolutel } \\
\text { y true }\end{array}$ \\
\hline 1 & $\begin{array}{l}\text { I'm looking for } \\
\text { opportunities to do } \\
\text { business of any kind }\end{array}$ & & & & & & & \\
\hline 2 & $\begin{array}{l}\text { I'm saving money to } \\
\text { start a business that I } \\
\text { have in mind }\end{array}$ & & & & & & & \\
\hline 3 & $\begin{array}{l}\text { I'm figuring out how to } \\
\text { start a business }\end{array}$ & & & & & & & \\
\hline 4 & $\begin{array}{l}\text { I do not plan on starting } \\
\text { a business }\end{array}$ & & & & & & & \\
\hline 5 & $\begin{array}{l}\text { I spend time learning } \\
\text { how to start a business }\end{array}$ & & & & & & & \\
\hline 6 & I intend to start a & & & & & & & \\
\hline
\end{tabular}




\section{ENTREPRENEURIAL SELF-EFFICACY}

13. From 0 to 100. How good do you consider yourself at the following tasks? (Rate yourself from 0 to 100)

\begin{tabular}{|l|l|l|}
\hline$\#$ & Questions & From 0 A 100 \\
\hline 1 & Find a new idea, product or service & \\
\hline 2 & $\begin{array}{l}\text { Get together with others to brainstorm in order to find new } \\
\text { products or services }\end{array}$ & \\
\hline 3 & Identify the need for a new product or service & \\
\hline 4 & $\begin{array}{l}\text { Design a product or service that meets the needs and desires } \\
\text { of potential customers }\end{array}$ & \\
\hline 5 & Estimate the demand that product could have & \\
\hline 6 & $\begin{array}{l}\text { Determine the optimal price at which the product should be } \\
\text { sold }\end{array}$ & \\
\hline 7 & Know how much money is needed to start a business & \\
\hline 8 & Design an effective campaign to sell a product or service & \\
\hline 9 & $\begin{array}{l}\text { Make others to believe in my idea and be inspired by my } \\
\text { future vision }\end{array}$ & \\
\hline 10 & Develop and utilize networking for the benefit of a business & \\
\hline 11 & Explain a business idea clearly and concisely & \\
\hline 12 & Supervise an employee or collaborator & \\
\hline 13 & Recruit and hire people & \\
\hline 14 & Delegate tasks and responsibilities to employees & \\
\hline 15 & $\begin{array}{l}\text { Effectively deal with the problems of everyday life of a } \\
\text { business }\end{array}$ & \\
\hline 16 & Inspire, encourage, and motivate employees & \\
\hline 17 & Train employees & \\
\hline 18 & Keep business accounts ordered & \\
\hline 19 & $\begin{array}{l}\text { Properly manage financial assets of a business (money , } \\
\text { machinery, and things of value) }\end{array}$ & \\
\hline 20 & Read and interpret financial statements & \\
\hline
\end{tabular}

VII. SUBJETIVA NORM SCALE (2 Questions)

14. What opinion will have or have friends and family if you become a business owner?

\begin{tabular}{|c|c|c|c|c|c|c|c|c|c|c|}
\hline \# & Questions & $\begin{array}{l}\text { very } \\
\text { negati } \\
\text { ve }\end{array}$ & $\begin{array}{l}\text { negati } \\
\text { ve }\end{array}$ & $\begin{array}{l}\text { somet } \\
\text { hing } \\
\text { negati } \\
\text { ve }\end{array}$ & $\begin{array}{l}\text { Neithe } \\
r \\
\text { positiv } \\
\text { e nor } \\
\text { negati } \\
\text { ve }\end{array}$ & $\begin{array}{l}\text { somet } \\
\text { hing } \\
\text { positiv } \\
\text { e }\end{array}$ & $\begin{array}{l}\text { positiv } \\
\mathrm{e}\end{array}$ & $\begin{array}{l}\text { very } \\
\text { positiv } \\
\text { e }\end{array}$ & $\begin{array}{l}\text { have } \\
\text { no } \\
\text { relatio } \\
\text { nship } \\
\text { with } \\
\text { my } \\
\text { family } \\
\text { or } \\
\text { friends }\end{array}$ & $\begin{array}{l}\text { I do } \\
\text { not } \\
\text { know }\end{array}$ \\
\hline 1 & $\begin{array}{l}\text { My family } \\
\text { would be } \\
\text { very } \\
\text { positive if I } \\
\text { started a } \\
\text { business }\end{array}$ & & & & & & & & & \\
\hline
\end{tabular}




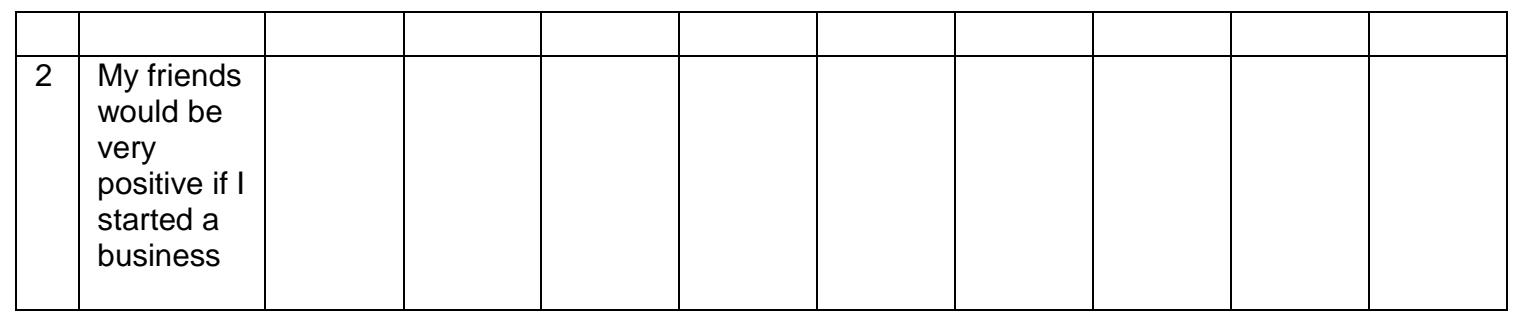

15. What do you think of the following statements?

\begin{tabular}{|c|l|l|l|l|l|l|l|l|}
\hline$\#$ & Questions & $\begin{array}{l}\text { Strongly } \\
\text { disagre } \\
\text { e }\end{array}$ & $\begin{array}{l}\text { Disagre } \\
\text { e }\end{array}$ & $\begin{array}{l}\text { Some } \\
\text { how } \\
\text { disagre } \\
\text { e }\end{array}$ & $\begin{array}{l}\text { Neither } \\
\text { agree } \\
\text { nor } \\
\text { disagre } \\
\text { e }\end{array}$ & $\begin{array}{l}\text { Some } \\
\text { how } \\
\text { agree }\end{array}$ & Agree & $\begin{array}{l}\text { Strongly } \\
\text { agree }\end{array}$ \\
\hline 1 & $\begin{array}{l}\text { Entrepreneurs play a } \\
\text { positive role in society }\end{array}$ & & & & & & & \\
\hline 2 & $\begin{array}{l}\text { Entrepreneurs help } \\
\text { foster inequality }\end{array}$ & & & & & & & \\
\hline 3 & $\begin{array}{l}\text { Employers contribute } \\
\text { to social welfare }\end{array}$ & & & & & & & \\
\hline 4 & $\begin{array}{l}\text { If are no } \\
\text { entrepreneurs, society } \\
\text { would be better }\end{array}$ & & & & & & & \\
\hline 5 & $\begin{array}{l}\text { Entrepreneurs inject } \\
\text { creativity and optimism } \\
\text { to society }\end{array}$ & & & & & & & \\
\hline 6 & $\begin{array}{l}\text { Without entrepreneurs } \\
\text { a country can become } \\
\text { happier }\end{array}$ & & & & & & & \\
\hline
\end{tabular}

VIII. ENTREPRENEURIAL ATTITUDE

16. Review the following statements and report how you agree with each.

\begin{tabular}{|l|l|l|l|l|l|l|}
\hline$\#$ & Questions & $\begin{array}{l}\text { Strongly } \\
\text { disagree }\end{array}$ & disagree & $\begin{array}{l}\text { Neither } \\
\text { agree nor } \\
\text { disagree }\end{array}$ & Agree & $\begin{array}{l}\text { Strongly } \\
\text { agree }\end{array}$ \\
\hline 1 & $\begin{array}{l}\text { I often think about becoming } \\
\text { a business owner }\end{array}$ & & & & & \\
\hline 2 & $\begin{array}{l}\text { I would like to see myself as } \\
\text { the owner of a company }\end{array}$ & & & & & \\
\hline 3 & $\begin{array}{l}\text { Becoming a business owner } \\
\text { is an important part of who I } \\
\text { am }\end{array}$ & & & & & \\
\hline 4 & $\begin{array}{l}\text { When I think of the term } \\
\text { "entrepreneur" I think it's }\end{array}$ & & & & & \\
\hline
\end{tabular}




\begin{tabular}{|l|l|l|l|l|l|l|}
\hline & something that suits me & & & & \\
\hline 5 & $\begin{array}{l}\text { I am one who is always } \\
\text { thinking about how to } \\
\text { become an entrepreneur }\end{array}$ & & & & & \\
\hline 6 & $\begin{array}{l}\text { It is important for me to talk } \\
\text { about my aspiration to } \\
\text { become an entrepreneur } \\
\text { someday }\end{array}$ & & & & & \\
\hline
\end{tabular}

IX. SOCIODEMOGRAFIC DATA (7 questions)

17. Please, point to the monthly household income in your household.

\begin{tabular}{|c|c|}
\hline Option & Chilean pesos range \\
\hline & $\$ 0 \quad-\$ 999.999$ \\
\hline & $\$ 1.000 .000-\$ 1.999 .999$ \\
\hline & $\$ 2.000 .000-$ \\
\hline & $\$ 3.000 .000-$ \\
\hline & $\$ 4.000 .000-\$ 4.999 .999$ \\
\hline & $\$ 5.000 .000-y$ mas \\
\hline
\end{tabular}

18. What is the work/job of your father?

19. What is the work/job of your mother?

20. What is the educational level of your father?

21. What is the educational level of your mother?

22. How many cars does your household own?

23. Does your household has domestic service?

\section{SUCCESS VALUATION OF PARENTS}

24. Do any of your parents own a company or business?

YES _ NO _ I DO NOT KNOW 
25. How many employees does your family business have?

26. How successful do you think is the family business? Note 1-7

27. Would you like to own a business like your family's?

YES _ _ NO _ _ I DO NOT KNOW

28. Once you are a college graduate, would you like to take care of the family business?

YES _ _ NO _ _ I DO NOT KNOW 


\section{APPENDIX C}

\section{SURVEY STUDENTS (SPANISH)}

\section{CONSENTIMIENTO INFORMADO}

Usted ha sido invitado a participar en el estudio "Efectos de un curso obligatorio de emprendimiento en la intención de emprender". El objetivo de este estudio es conocer el efecto que un curso obligatorio de emprendimiento tiene en la intención a emprender en sus estudiantes. Tu participación consistirá en responder preguntas de una encuesta al comienzo y al final de su curso de emprendimiento. La encuesta tomará aproximadamente 20 minutos responder. Toda información que se recoja será confidencial, por lo que no se usará para ningún otro propósito fuera de esta investigación. Las respuestas al cuestionario serán codificadas usando un número de identificación y se manejarán de forma anónima. Dicha información no será conocida por otras personas que no sean el investigador titular o la persona a cargo de los estudios. Usted puede negarse a contestar algunas preguntas y puede retirar su participación en el estudio en cualquier momento que desee. Si tiene alguna duda sobre este proyecto, puede hacer preguntas en cualquier momento durante su participación en él. Este proyecto cuenta con el apoyo de FONDECYT. El $\mathrm{N}^{\circ}$ de proyecto es 11121458 y está a cargo del Dr. Carlos Albornoz (calbornoz@udd.cl), profesor de la Facultad de Economía y Negocios de la Universidad del Desarrollo.

ACEPTO PARTICIPAR

NO ACEPTO

II. DATOS DEMOGRAFICOS (7 preguntas)

\section{RUT (Sin puntos ni guion):}

2. Email:

3. Año de nacimiento:

4. Género: Femenino ___ Masculino

5. Nombre de la universidad en la que estudia:

6. Nombre del profesor(a) que realiza el curso:

7. Carrera que está cursando:

III. INTENCION Y ACTITUD EMPRENDEDORA (GEM) (3 Preguntas)

12. ¿Estás pensando en poner en marcha un nuevo negocio en los próximos 12 meses? (incluyendo cualquier tipo de autoempleo o venta de cualquier tipo de bienes y/o servicios a otros)

_si no no no sabe

13. ¿Crees tener los conocimientos, habilidades y experiencia requerida para poner en marcha un nuevo negocio?

si _ no _ no sabe

14. Al terminar tu carrera como te visualizas (en qué sector te gustaría desempeñarte profesionalmente): 
IV. RECHAZO DEL CURSO

15. ¿Qué opinas de las siguientes afirmaciones?

\begin{tabular}{|l|l|l|l|l|l|}
\hline$\#$ & PREGUNTAS & $\begin{array}{l}\text { Muy en } \\
\text { desacuerdo }\end{array}$ & $\begin{array}{l}\text { Medianamente } \\
\text { en desacuerdo }\end{array}$ & $\begin{array}{l}\text { Medianamente } \\
\text { de acuerdo }\end{array}$ & $\begin{array}{l}\text { Mu de } \\
\text { acuerdo }\end{array}$ \\
\hline 1 & $\begin{array}{l}\text { No tomaría este curso si de } \\
\text { mí dependiera (si fuese } \\
\text { voluntario) }\end{array}$ & & & & \\
\hline 2 & $\begin{array}{l}\text { Este curso escasamente } \\
\text { contribuye a mi formación } \\
\text { profesional }\end{array}$ & & & & \\
\hline 3 & $\begin{array}{l}\text { Creo que este curso tendrá } \\
\text { poco impacto en mis } \\
\text { habilidades emprendedoras }\end{array}$ & & & & \\
\hline 4 & $\begin{array}{l}\text { Tomar emprendimiento en los } \\
\text { primeros años de la } \\
\text { universidad es una pérdida } \\
\text { de tiempo }\end{array}$ & & & & \\
\hline 5 & $\begin{array}{l}\text { Aprender a emprender es } \\
\text { una pérdida de tiempo }\end{array}$ & & & & \\
\hline 6 & $\begin{array}{l}\text { Desearía que fueran } \\
\text { obligatorios otros cursos, que } \\
\text { estuvieran más relacionados } \\
\text { con mi carrera universitaria }\end{array}$ & & & & \\
\hline 7 & $\begin{array}{l}\text { No se puede enseñar a } \\
\text { emprender }\end{array}$ & & & & \\
\hline 8 & $\begin{array}{l}\text { No es necesario un curso de } \\
\text { emprendimiento para crear } \\
\text { un negocio }\end{array}$ & & & & \\
\hline 9 & $\begin{array}{l}\text { En general me molestan los } \\
\text { cursos obligatorios }\end{array}$ & & & & \\
\hline
\end{tabular}

V. ESCALA DE INTENCION EMPRENDEDORA

12. ¿Qué opinas de las siguientes afirmaciones relativas a tus intenciones de iniciar un negocio?

\begin{tabular}{|c|c|c|c|c|c|c|c|c|}
\hline$\#$ & Pregunta & $\begin{array}{l}\text { Absoluta } \\
\text { mente } \\
\text { falso }\end{array}$ & Falso & $\begin{array}{l}\text { Un poco } \\
\text { falso }\end{array}$ & $\begin{array}{l}\mathrm{Ni} \\
\text { verdad } \\
\text { ero ni } \\
\text { falso } \\
\end{array}$ & $\begin{array}{l}\text { Algo } \\
\text { de } \\
\text { verdad }\end{array}$ & $\begin{array}{l}\text { Verdad } \\
\text { ero }\end{array}$ & $\begin{array}{l}\text { Absoluta } \\
\text { mente } \\
\text { cierto }\end{array}$ \\
\hline 1 & $\begin{array}{l}\text { No ando } \\
\text { buscando } \\
\text { oportunidades } \\
\text { para hacer } \\
\text { negocios de } \\
\text { ningún tipo }\end{array}$ & & & & & & & \\
\hline 2 & $\begin{array}{l}\text { Estoy ahorrando } \\
\text { dinero para } \\
\text { comenzar un } \\
\text { negocio que } \\
\text { tengo en mente }\end{array}$ & & & & & & & \\
\hline 3 & $\begin{array}{l}\text { No ando } \\
\text { averiguando } \\
\text { cómo iniciar un } \\
\text { negocio }\end{array}$ & & & & & & & \\
\hline 4 & $\begin{array}{l}\text { No tengo planes } \\
\text { de partir un }\end{array}$ & & & & & & & \\
\hline
\end{tabular}




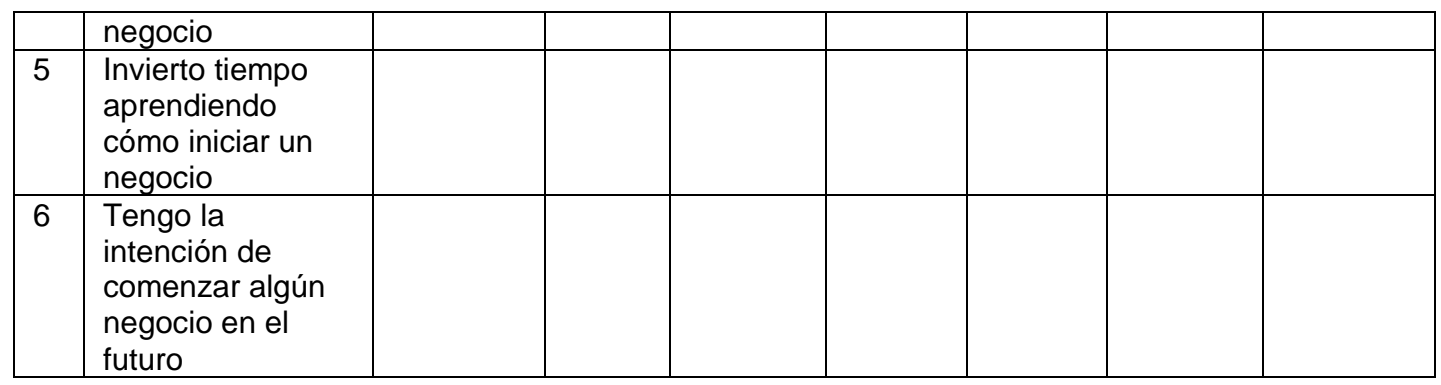

\section{AUTOEFICACIA EMPRENDEDORA}

13. De 0 a 100, ¿Qué tan bueno te consideras para hacer las siguientes tareas? (evalúate de 0 a 100)

\begin{tabular}{|l|l|l|}
\hline$\#$ & Preguntas & De 0 A 100 \\
\hline 1 & Encontrar una idea nueva de producto o servicio & \\
\hline 2 & $\begin{array}{l}\text { Juntarme con otros a hacer lluvia de ideas para encontrar } \\
\text { nuevos productos o servicios }\end{array}$ & \\
\hline 3 & Identificar la necesidad de un nuevo producto o servicio & \\
\hline 4 & $\begin{array}{l}\text { Diseñar un producto o servicio que satisface las necesidades } \\
\text { o deseos de potenciales clientes }\end{array}$ & \\
\hline 5 & Estimar la demanda que tendría un producto & \\
\hline 6 & $\begin{array}{l}\text { Determinar el precio óptimo al cual debiera venderse el } \\
\text { producto }\end{array}$ & \\
\hline 7 & Saber cuánto dinero se necesita para comenzar un negocio & \\
\hline 8 & $\begin{array}{l}\text { Diseñar una campaña efectiva para vender un producto o } \\
\text { servicio }\end{array}$ & \\
\hline 9 & $\begin{array}{l}\text { Hacer que otros crean en mi idea y se inspiren en mi visión } \\
\text { del futuro }\end{array}$ & \\
\hline 10 & $\begin{array}{l}\text { Desarrollar y utilizar redes de contactos en beneficio de un } \\
\text { negocio }\end{array}$ & \\
\hline 11 & Explicar, de manera clara y concisa, una idea de negocio & \\
\hline 12 & Supervisar empleados & \\
\hline 13 & Reclutar y contratar personas & \\
\hline 14 & Delegar tareas y responsabilidades en los empleados & \\
\hline 15 & $\begin{array}{l}\text { Lidiar efectivamente con los problemas del día a día de un } \\
\text { negocio }\end{array}$ & \\
\hline 16 & Inspirar, animar, y motivar empleados & \\
\hline 17 & Entrenar empleados & \\
\hline 18 & Mantener las cuentas del negocio ordenadas & \\
\hline 19 & $\begin{array}{l}\text { Manejar adecuadamente activos financieros de un negocio } \\
\text { (dinero, maquinarias, y cosas de valor) }\end{array}$ & \\
\hline 20 & Leer e interpretar balances financieros & \\
\hline
\end{tabular}

\section{NORMA SUBJETIVA (2 preguntas)}

14. ¿Qué opinión cree usted que tienen o tendrían sus familiares y amigos si usted se convirtiera en dueño de un negocio?

\begin{tabular}{|c|c|c|c|c|c|c|c|c|c|c|}
\hline \# & Pregunta & $\begin{array}{l}\text { Muy } \\
\text { nega } \\
\text { tiva }\end{array}$ & $\begin{array}{l}\text { neg } \\
\text { ativ } \\
0\end{array}$ & $\begin{array}{l}\text { Algo } \\
\text { negati } \\
\text { vo }\end{array}$ & $\begin{array}{l}\mathrm{Ni} \\
\text { posi } \\
\text { tiva } \\
\text { ni } \\
\text { neg } \\
\text { ativ } \\
\text { a }\end{array}$ & $\begin{array}{l}\text { Algo } \\
\text { positiv } \\
\text { a }\end{array}$ & $\begin{array}{l}\text { positiv } \\
\text { a }\end{array}$ & $\begin{array}{l}\text { Muy } \\
\text { positiv } \\
\text { a }\end{array}$ & $\begin{array}{l}\text { No } \\
\text { tengo } \\
\text { relació } \\
\mathrm{n} \text { con } \\
\text { mi } \\
\text { familia } \\
\text { o }\end{array}$ & No se \\
\hline
\end{tabular}




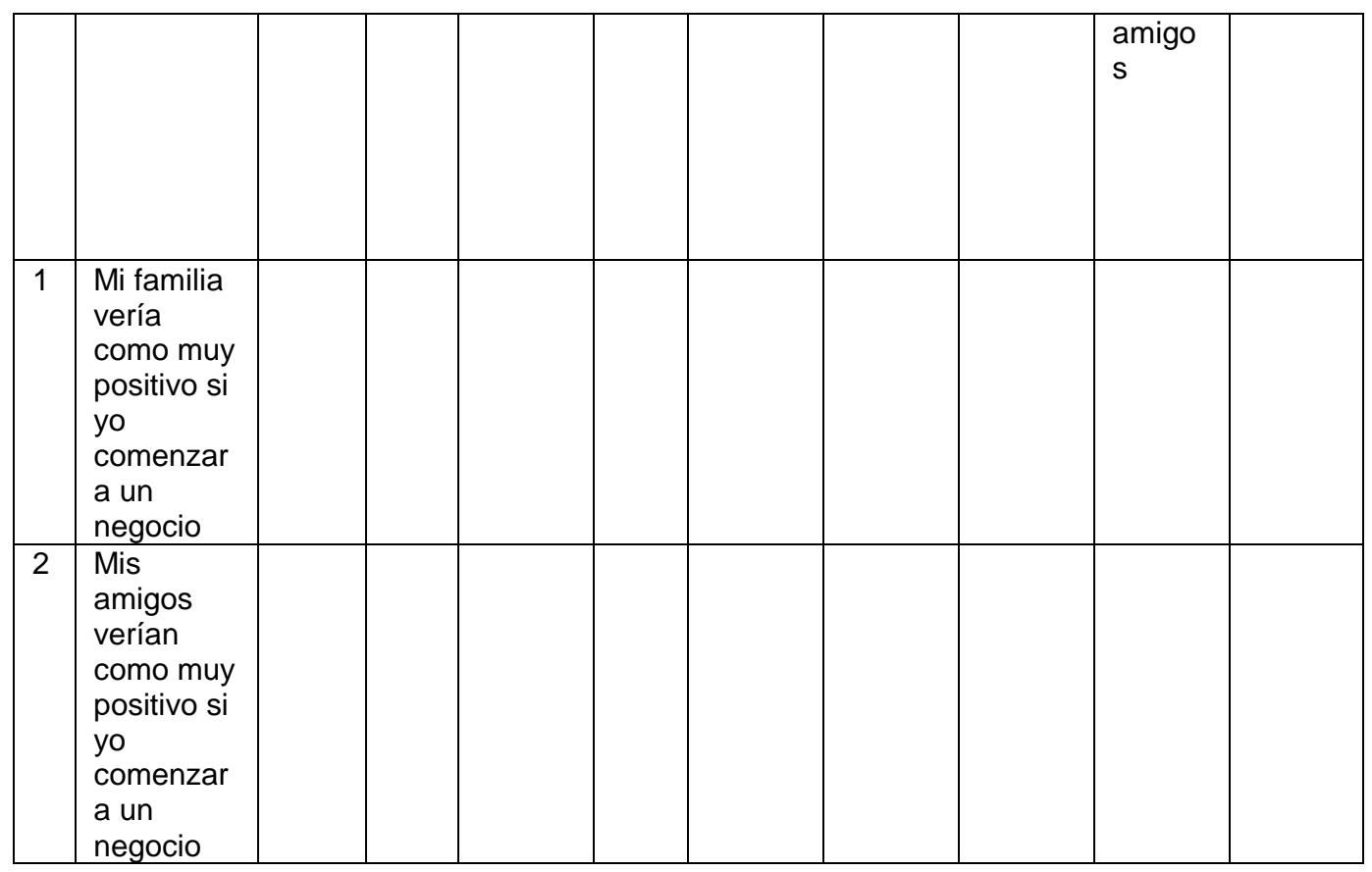

15. ¿Qué opinas de las siguientes afirmaciones?

\begin{tabular}{|c|c|c|c|c|c|c|c|c|}
\hline$\#$ & Pregunta & $\begin{array}{l}\text { Muy en } \\
\text { desacu } \\
\text { erdo }\end{array}$ & $\begin{array}{l}\text { En } \\
\text { desacu } \\
\text { erdo }\end{array}$ & $\begin{array}{l}\text { Algo en } \\
\text { desacu } \\
\text { erdo }\end{array}$ & $\begin{array}{l}\text { Ni de } \\
\text { acuerdo } \\
\text { ni en } \\
\text { desacu } \\
\text { erdo }\end{array}$ & $\begin{array}{l}\text { Algo de } \\
\text { acuerdo }\end{array}$ & $\begin{array}{l}\text { En } \\
\text { acuerdo }\end{array}$ & $\begin{array}{l}\text { Muy de } \\
\text { acuerdo }\end{array}$ \\
\hline 1 & $\begin{array}{l}\text { Los } \\
\text { empresarios } \\
\text { juegan un rol } \\
\text { positivo en la } \\
\text { sociedad }\end{array}$ & & & & & & & \\
\hline 2 & $\begin{array}{l}\text { Los } \\
\text { empresarios } \\
\text { contribuyen a } \\
\text { fomentar la } \\
\text { desigualdad }\end{array}$ & & & & & & & \\
\hline 3 & $\begin{array}{l}\text { Los } \\
\text { empresarios } \\
\text { contribuyen al } \\
\text { bienestar } \\
\text { social }\end{array}$ & & & & & & & \\
\hline 4 & $\begin{array}{l}\text { Si no hubiera } \\
\text { empresarios } \\
\text { la sociedad } \\
\text { estaría mejor }\end{array}$ & & & & & & & \\
\hline 5 & $\begin{array}{l}\text { Los } \\
\text { empresarios } \\
\text { inyectan } \\
\text { creatividad y }\end{array}$ & & & & & & & \\
\hline
\end{tabular}




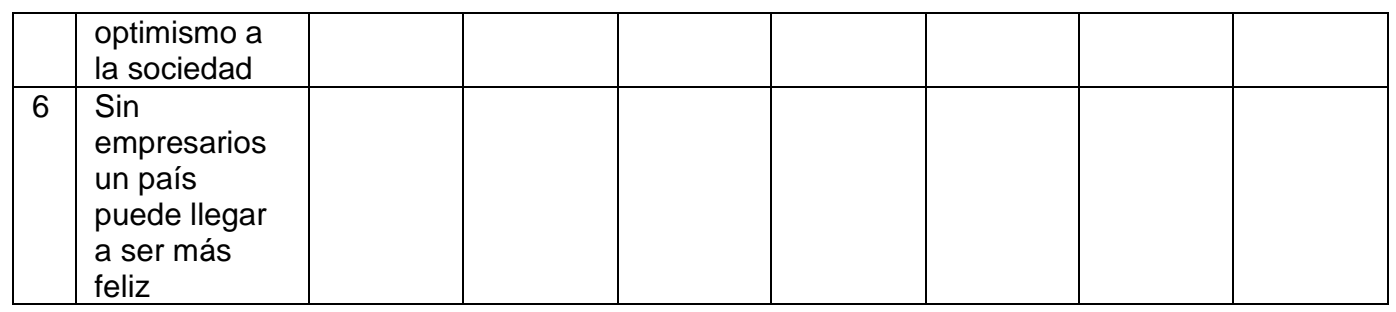

VIII. ACTITUD EMPRENDEDORA

16. Revise las siguientes afirmaciones y reporte que tan de acuerdo estás con cada una de ellas.

\begin{tabular}{|c|c|c|c|c|c|c|}
\hline$\#$ & PREGUNTAS & $\begin{array}{l}\text { Muy en } \\
\text { desacuerd } \\
0\end{array}$ & $\begin{array}{l}\text { En } \\
\text { desacuerd } \\
0\end{array}$ & $\begin{array}{l}\text { Ni de } \\
\text { acuerdo ni } \\
\text { en } \\
\text { desacuerd } \\
\text { o }\end{array}$ & $\begin{array}{l}\text { De } \\
\text { acuerdo }\end{array}$ & $\begin{array}{l}\text { Muy de } \\
\text { acuerdo }\end{array}$ \\
\hline 1 & $\begin{array}{l}\text { A menudo pienso } \\
\text { en llegar a ser } \\
\text { dueño de una } \\
\text { empresa }\end{array}$ & & & & & \\
\hline 2 & $\begin{array}{l}\text { Me gustaría llegar a } \\
\text { verme a mí mismo } \\
\text { como el dueño de } \\
\text { una empresa }\end{array}$ & & & & & \\
\hline 3 & $\begin{array}{l}\text { Llegar a ser dueño } \\
\text { de una empresa } \\
\text { forma parte } \\
\text { importante de quien } \\
\text { yo soy }\end{array}$ & & & & & \\
\hline 4 & $\begin{array}{l}\text { Cuando pienso en } \\
\text { el concepto } \\
\text { "Empresario", creo } \\
\text { que es algo que me } \\
\text { queda bien }\end{array}$ & & & & & \\
\hline 5 & $\begin{array}{l}\text { Soy de los que } \\
\text { anda siempre } \\
\text { pensando en cómo } \\
\text { convertirme en } \\
\text { empresario }\end{array}$ & & & & & \\
\hline 6 & $\begin{array}{l}\text { Es importante para } \\
\text { mi hablar de mi } \\
\text { aspiración de } \\
\text { convertirme en } \\
\text { empresario algún } \\
\text { día }\end{array}$ & & & & & \\
\hline
\end{tabular}

\section{DATOS SOCIODEMOGRAFICOS (7 preguntas)}

17. Señale el ingreso familiar mensual de su grupo familiar. 


\begin{tabular}{|l|l|}
\hline $\begin{array}{l}\text { Marque la } \\
\text { opción }\end{array}$ & Rango en Pesos Chilenos \\
\hline & $\$ 0 \quad-\$ 999.999$ \\
\hline & $\$ 1.000 .000-\$ 1.999 .999$ \\
\hline & $\$ 2.000 .000-\$ 2.999 .999$ \\
\hline & $\$ 3.000 .000-\$ 3.999 .999$ \\
\hline & $\$ 4.000 .000-\$ 4.999 .999$ \\
\hline & $\$ 5.000 .000-$ y mas \\
\hline
\end{tabular}

18. ¿Cuál es la ocupación de tu Padre?

19. ¿Cuál es la ocupación de tu Madre?

20. ¿Cuál es el nivel educacional de tu padre?

21. ¿Cuál es el nivel educacional de tu madre?

22. ¿Cuántos autos propios o pagándose tiene tu hogar?

23. ¿Tu hogar cuenta con servicio doméstico?

$$
\mathrm{SI} \_ \text {NO _ NO SE }
$$

\section{VALORACION DE ÉXITO EN EL EMPRENDIMIENTO DE LOS PADRES}

24. ¿Es alguno de tus padres dueño de una empresa o negocio?

$$
\mathrm{SI} \_ \text {NO_ NO SE _ _ }
$$

25. ¿Cuántos empleados tiene el negocio familiar?

26. ¿Cuán exitoso piensas que es el negocio familiar? Nota de 1 a 7

27. ¿Te gustaría ser dueño de un negocio como el que tiene tu familia?

SI__ NO _ NO SE

28. Una vez egresado de la universidad ¿Te gustaría encargarte del negocio familiar?

$\mathrm{SI} \_$NO_ NO SE _ _ 


\section{APPENDIX D}

\section{SURVEY FACULTY (ENGLISH)}

\section{INFORMED CONSENT}

You have been invited to participate in a study of the "effects of a required course in the entrepreneurship intention." The aim of this study is to determine the effect that a required course in entrepreneurship has on students' entrepreneurial intentions. When answering, please think in the course of undertaking that is currently teaching or will teach in the near future. The survey will take approximately 20 minutes to answer. All information collected will be confidential and will not be used for any other purpose outside of this research. Responses to the questionnaire will be coded using an identification number and will be handled anonymously. This information will not be known by people other than the researcher or the person in charge of the research data. You may refuse to answer any questions and may withdraw your participation in the study at any time you want. If you have any questions about this project, you can ask questions at any time during your participation. This project has the support of FONDECYT. The project No. is 11121458 and is in charge of Dr. Carlos Albornoz (calbronoz@udd.cl), professor of the Faculty of Economics and Business, at Universidad del Desarrollo, Santiago, Chile.

I AGREE I DISAGREE

\section{ENTREPRENEURIAL SELF-EFFICACY}

1. From 0 to 100 . How good do you consider yourself at the following tasks? (Rate yourself from 0 to 100)

\begin{tabular}{|l|l|l|}
\hline$\#$ & Questions & From 0 A 100 \\
\hline 1 & Find a new idea, product, or service & \\
\hline 2 & $\begin{array}{l}\text { Get together with others to brainstorm in order to find new } \\
\text { products or services }\end{array}$ & \\
\hline 3 & Identify the need for a new product or service & \\
\hline 4 & $\begin{array}{l}\text { Design a product or service that meets the needs and desires } \\
\text { of potential customers }\end{array}$ & \\
\hline 5 & Estimate the demand that product could have & \\
\hline 6 & $\begin{array}{l}\text { Determine the optimal price at which the product should be } \\
\text { sold }\end{array}$ & \\
\hline 7 & Know how much money is needed to start a business & \\
\hline 8 & Design an effective campaign to sell a product or service & \\
\hline 9 & $\begin{array}{l}\text { Make others believe in my idea and be inspired by my future } \\
\text { vision }\end{array}$ & \\
\hline 10 & Develop and utilize networking for the benefit of a business & \\
\hline 11 & Explain a business idea clearly and concisely & \\
\hline 12 & Supervise an employee or collaborator & \\
\hline 13 & Recruit and hire people & \\
\hline 14 & Delegate tasks and responsibilities to employees & \\
\hline 15 & $\begin{array}{l}\text { Effectively deal with the problems of everyday life of a } \\
\text { business }\end{array}$ & \\
\hline 16 & Inspire, encourage, and motivate employees & \\
\hline 17 & Train employees & \\
\hline 18 & Keep business accounts ordered & \\
\hline 19 & $\begin{array}{l}\text { Properly manage financial assets of a business (money , } \\
\text { machinery, and things of value) }\end{array}$ & \\
\hline 20 & Read and interpret financial statements & \\
\hline
\end{tabular}




\section{TEACHING PERSPECTIVE INVENTORY (TPI: 3 ITEMS)}

2. What do you believe about instruction or teaching? (BELIEFS)

For each statement, select the response that best represents your Agreement or Disagreement.

\begin{tabular}{|c|c|c|c|c|c|c|}
\hline$\#$ & QUESTIONS & $\begin{array}{l}\text { Strongly } \\
\text { disagree }\end{array}$ & disagree & $\begin{array}{l}\text { Neither } \\
\text { agree nor } \\
\text { disagree }\end{array}$ & Agree & $\begin{array}{l}\text { Strongly } \\
\text { agree }\end{array}$ \\
\hline 1 & $\begin{array}{l}\text { Learning benefits from having } \\
\text { predetermined goals. }\end{array}$ & & & & & \\
\hline 2 & $\begin{array}{l}\text { To be an effective teacher one must } \\
\text { practice what ones preaches }\end{array}$ & & & & & \\
\hline 3 & $\begin{array}{l}\text { Above all, learning depends on what } \\
\text { one already knows }\end{array}$ & & & & & \\
\hline 4 & $\begin{array}{l}\text { It is important to recognize the } \\
\text { emotional reactions of students }\end{array}$ & & & & & \\
\hline 5 & $\begin{array}{l}\text { My teaching focuses on social } \\
\text { change, not the individual student }\end{array}$ & & & & & \\
\hline 6 & $\begin{array}{l}\text { Teachers should have a complete } \\
\text { mastery of their subject }\end{array}$ & & & & & \\
\hline 7 & $\begin{array}{l}\text { The best learning comes from } \\
\text { working with skilled professionals }\end{array}$ & & & & & \\
\hline 8 & $\begin{array}{l}\text { Education should focus on the } \\
\text { development of qualitative changes in } \\
\text { thinking }\end{array}$ & & & & & \\
\hline 9 & $\begin{array}{l}\text { In my teaching, building confidence } \\
\text { in students is a priority }\end{array}$ & & & & & \\
\hline 10 & $\begin{array}{l}\text { Individual learning without social } \\
\text { change is not enough }\end{array}$ & & & & & \\
\hline 11 & $\begin{array}{l}\text { Effective teachers must first be } \\
\text { experts in their own subject areas }\end{array}$ & & & & & \\
\hline 12 & $\begin{array}{l}\text { Knowledge and its application cannot } \\
\text { be separated }\end{array}$ & & & & & \\
\hline 13 & $\begin{array}{l}\text { Education should be based on what } \\
\text { people already know }\end{array}$ & & & & & \\
\hline 14 & $\begin{array}{l}\text { In learning, the effort of the people } \\
\text { should be rewarded as much as } \\
\text { accomplishment }\end{array}$ & & & & & \\
\hline 15 & $\begin{array}{l}\text { For me, teaching is a moral act as } \\
\text { well as an intellectual activity }\end{array}$ & & & & & \\
\hline
\end{tabular}


3. What do you try to accomplish in your instruction or teaching? (INTENTIONS)

For each statement, select the response that best represents how OFTEN it represents your educational intention.

\begin{tabular}{|c|c|c|c|c|c|c|}
\hline$\#$ & PREGUNTAS & $\begin{array}{l}\mathrm{N}= \\
\text { Never }\end{array}$ & $\begin{array}{l}\mathrm{R}= \\
\text { Rarely }\end{array}$ & $\begin{array}{l}\text { S= } \\
\text { Sometim } \\
\text { es }\end{array}$ & $\begin{array}{l}U= \\
\text { Usually }\end{array}$ & $\begin{array}{l}\mathrm{A}= \\
\text { Alway } \\
\mathrm{s}\end{array}$ \\
\hline 1 & $\begin{array}{l}\text { My intent is to prepare students for } \\
\text { examinations }\end{array}$ & & & & & \\
\hline 2 & $\begin{array}{l}\text { My purpose is to demonstrate how to } \\
\text { perform or work in real conditions }\end{array}$ & & & & & \\
\hline 3 & $\begin{array}{l}\text { My purpose is to help people develop } \\
\text { more sophisticated methods of } \\
\text { reasoning }\end{array}$ & & & & & \\
\hline 4 & $\begin{array}{l}\text { My purpose is to encourage my } \\
\text { students to develop self-esteem and } \\
\text { confidence as learners }\end{array}$ & & & & & \\
\hline 5 & $\begin{array}{l}\text { My purpose is to make people } \\
\text { reconsider their values seriously }\end{array}$ & & & & & \\
\hline 6 & $\begin{array}{l}\text { I hope people are able to handle a } \\
\text { large amount of information related to } \\
\text { the subject }\end{array}$ & & & & & \\
\hline 7 & $\begin{array}{l}\text { I expect people to implement the } \\
\text { content of the subject in real life }\end{array}$ & & & & & \\
\hline 8 & $\begin{array}{l}\text { I hope that people develop new ways } \\
\text { of thinking about the subject content }\end{array}$ & & & & & \\
\hline 9 & $\begin{array}{l}\text { I expect people to increase their self- } \\
\text { esteem through my teaching } \\
\text { methodology }\end{array}$ & & & & & \\
\hline 10 & $\begin{array}{l}\text { I hope people are committed to } \\
\text { changing our society }\end{array}$ & & & & & \\
\hline 11 & $\begin{array}{l}\text { I want people to get good grades on } \\
\text { tests thanks to my teaching methods }\end{array}$ & & & & & \\
\hline 12 & $\begin{array}{l}\text { I want people to understand the } \\
\text { reality of the working world }\end{array}$ & & & & & \\
\hline 13 & $\begin{array}{l}\text { I want people to realize how complex } \\
\text { and interrelated things are }\end{array}$ & & & & & \\
\hline 14 & $\begin{array}{l}\text { I want to keep a balance between my } \\
\text { concern and challenging students } \\
\text { when I teach }\end{array}$ & & & & & \\
\hline 15 & $\begin{array}{l}\text { I want to make clear what people take } \\
\text { for granted in a society }\end{array}$ & & & & & \\
\hline
\end{tabular}


4. What do you do when instructing or teaching? (ACTIONS)

For each statement, select the response that best represents how OFTEN you do that action.

\begin{tabular}{|c|c|c|c|c|c|c|}
\hline$\#$ & QUESTIONS & $\begin{array}{l}\mathrm{N}= \\
\text { Never }\end{array}$ & $\begin{array}{l}\mathrm{R}= \\
\text { Rarely }\end{array}$ & $\begin{array}{l}\text { S= } \\
\text { Sometim } \\
\text { es }\end{array}$ & $\begin{array}{l}U= \\
\text { Usually }\end{array}$ & $\begin{array}{l}\mathrm{A}= \\
\text { Alway } \\
\mathrm{S}\end{array}$ \\
\hline 1 & $\begin{array}{l}\text { I cover the content of the material } \\
\text { accurately and at the indicated time }\end{array}$ & & & & & \\
\hline 2 & $\begin{array}{l}\text { I relate the course content to } \\
\text { applications of real-life scenarios }\end{array}$ & & & & & \\
\hline 3 & $\begin{array}{l}\text { I ask a lot of questions while } \\
\text { teaching }\end{array}$ & & & & & \\
\hline 4 & $\begin{array}{l}\text { I always find something } \\
\text { praiseworthy in the work or the } \\
\text { contribution of each person }\end{array}$ & & & & & \\
\hline 5 & $\begin{array}{l}\text { I use the content of the material as a } \\
\text { way to teach values }\end{array}$ & & & & & \\
\hline 6 & $\begin{array}{l}\text { My teaching is guided by the } \\
\text { objectives of the course }\end{array}$ & & & & & \\
\hline 7 & $\begin{array}{l}\text { I show the skills and methods } \\
\text { involved in good teaching practice }\end{array}$ & & & & & \\
\hline 8 & $\begin{array}{l}\text { I challenge familiar ways of } \\
\text { understanding the content of the } \\
\text { subject }\end{array}$ & & & & & \\
\hline 9 & $\begin{array}{l}\text { I promote the expression of feelings } \\
\text { and emotions }\end{array}$ & & & & & \\
\hline 10 & $\begin{array}{l}\text { I present values that emphasize } \\
\text { more academic content area }\end{array}$ & & & & & \\
\hline 11 & I review what has been learned & & & & & \\
\hline 12 & $\begin{array}{l}\text { I think novices learn from people } \\
\text { with experience }\end{array}$ & & & & & \\
\hline 13 & $\begin{array}{l}\text { I promote questioning the thinking of } \\
\text { others }\end{array}$ & & & & & \\
\hline 14 & $\begin{array}{l}\text { I share my feelings and expect the } \\
\text { same from my students }\end{array}$ & & & & & \\
\hline 15 & $\begin{array}{l}\text { I help people see the need for } \\
\text { changes in society }\end{array}$ & & & & & \\
\hline
\end{tabular}




\section{PEDAGOGIES USED IN AN ENTREPRENEURSHIP COURSE}

5. Do you use some the next activities in your entrepreneurship class?

\begin{tabular}{|l|l|l|l|}
\hline$\#$ & Questions & YES & NO \\
\hline 1 & Case studies (Harvard type) & & \\
\hline 2 & $\begin{array}{l}\text { Readings / topics students for subsequent } \\
\text { group discussion }\end{array}$ & & \\
\hline 3 & Business consulting done by students & & \\
\hline 4 & $\begin{array}{l}\text { Development of business plans by students in } \\
\text { groups }\end{array}$ & & \\
\hline 5 & $\begin{array}{l}\text { Essays, blogs that stimulate individual } \\
\text { reflection }\end{array}$ & & \\
\hline 6 & Give feedback to "shake" the thinking & & \\
\hline 7 & Interviews with entrepreneurs & \\
\hline 8 & Implement group dynamics in the classroom & & \\
\hline 9 & Implement games or outdoor group dynamics & & \\
\hline 10 & I invite guest speakers/entrepreneurs & & \\
\hline 11 & I show videos to students & & \\
\hline 12 & Power point presentation and/or the board & & \\
\hline 13 & Computer simulations & & \\
\hline 14 & Company visits (field trips) & & \\
\hline
\end{tabular}

6. Which one of the methodologies or approaches mentioned in the previous question you have received some training?

\begin{tabular}{|l|l|l|l|}
\hline$\#$ & QUESTIONS & YES & NO \\
\hline 1 & Case studies (Harvard type) & & \\
\hline 2 & $\begin{array}{l}\text { Readings / topics students for subsequent } \\
\text { group discussion }\end{array}$ & & \\
\hline 3 & Business consulting done by students & & \\
\hline 4 & $\begin{array}{l}\text { Development of business plans by students in } \\
\text { groups }\end{array}$ & & \\
\hline 5 & $\begin{array}{l}\text { Essays, blogs that stimulate individual } \\
\text { reflection }\end{array}$ & & \\
\hline 6 & Give feedback to "shake" the thinking & & \\
\hline 7 & Interviews with entrepreneurs & \\
\hline 8 & Implement group dynamics in the classroom & & \\
\hline 9 & Implement games or outdoor group dynamics & & \\
\hline 10 & I invite guest speakers/entrepreneurs & & \\
\hline 11 & I show videos to students & & \\
\hline 12 & Power point presentation and/or the board & & \\
\hline 13 & Computer simulations & & \\
\hline 14 & Company visits (field trips) & & \\
\hline
\end{tabular}

\section{COURSE DETAILS}

7. What is the name of the course you teach?

8. What is the main objective (learning outcome) of your entrepreneurship course you are teaching? 


\section{ASSESSMENT/EVALUATION}

7. Do you use some of the following methods to verify your students have met the learning objectives of the course?

\begin{tabular}{|l|l|l|l|l|}
\hline$\#$ & QUESTIONS & YES & NO & $\begin{array}{l}\text { I DO NOT } \\
\text { KNOW }\end{array}$ \\
\hline 1 & Written exam & & & \\
\hline 2 & Oral exam & & & \\
\hline 3 & Business plan written by students in group & & & \\
\hline 4 & $\begin{array}{l}\text { Report interview entrepreneurs conducted by } \\
\text { the students }\end{array}$ & & & \\
\hline 5 & Group presentations & & & \\
\hline 6 & Videos made by students & & & \\
\hline 7 & Games or simulations of business creation & & & \\
\hline 8 & Tests / Individual papers & & & \\
\hline
\end{tabular}

\section{ENTREPRENEURIAL EXPERIENCE}

8. Have you had owned a business in the past?

YES NO

9. How many employees did the business have?

10. Do you currently own a business?

YES NO

11. How many employees does your business have?

\section{PROFESSIONAL AND ACADEMIC EXPERIENCE}

12. What is your profession or occupation?

13. What do you currently do for a living?

14. What is the highest educational level you reached?

15. How much time do you devote to the academy (What kind of contract do you have with the institution of higher education)?

16. How much time devote of your teaching in entrepreneurship? 
17. What is your main motivation for entrepreneurship classes?

\begin{tabular}{|l|l|l|l|}
\hline$\#$ & QUESTIONS & Agree & Disagree \\
\hline 1 & It is assigned to me. & & \\
\hline 2 & I believe I have the skills for doing it & & \\
\hline 3 & $\begin{array}{l}\text { I am interested in the subject of } \\
\text { entrepreneurship. }\end{array}$ & & \\
\hline 4 & To generate extra income. & & \\
\hline
\end{tabular}

18. How many years have you been teaching entrepreneurship?

19. Have you had training on how to make students learn more and better (how to be a better teacher)?

YES _ NO _ I I DO NOT KNOW

20. What training did you receive on how to make students learn better?

21. Approximately, how many hours of pedagogical training do you estimate have you received throughout your career?

22. Have you had specific training on how to teach entrepreneurship?

YES _ NO _ I I DO NOT KNOW

23. Please describe what type of training you have received to teach entrepreneurship.

24. Did you have specific training on?

\begin{tabular}{|l|l|l|l|l|}
\hline$\#$ & TIPO DE ENTRENAMIENTO & YES & NO & $\begin{array}{l}\text { I DO NO } \\
\text { KNOW }\end{array}$ \\
\hline 1 & Canvas Model by Osterwalder & & & \\
\hline 2 & Ontological Language & & & \\
\hline 3 & Ontological coaching & & & \\
\hline 4 & NLP (Neurolinguistic Programming) & & & \\
\hline 5 & Lean StartUp & & & \\
\hline 6 & Enneagram & & & \\
\hline 7 & Design Thinking & & & \\
\hline 8 & Timmons Model & & & \\
\hline 9 & Empretec & & & \\
\hline 10 & Cociotechnology & & & \\
\hline 11 & Biology of Knowledge & & & \\
\hline 12 & The Game Plan (Time Zero) & & & \\
\hline 13 & CEFE & & & \\
\hline 14 & Babson College Model & & & \\
\hline 15 & Effectual Thinking & & & \\
\hline 16 & Case Studies development & & \\
\hline
\end{tabular}


25. Do you want to say anything more about the specific training your received?

VIII. TEACHING-LEARING GOALS FOR THE ENTREPRENEURSHIP COURSE

26. In relation to the entrepreneurship course that you are currently teaching, to what extent are each of the following objectives you plan to achieve with your classes:

\begin{tabular}{|c|l|l|l|l|l|}
\hline$\#$ & QUESTIONS & Much & Some & Little & None \\
\hline 1 & Develop problem solving skills. & & & & \\
\hline 2 & $\begin{array}{l}\text { Develop skills to make reasonable inferences from } \\
\text { observations. }\end{array}$ & & & & \\
\hline 3 & $\begin{array}{l}\text { Develop skills to synthesize and integrate information } \\
\text { and ideas. }\end{array}$ & & & & \\
\hline 4 & $\begin{array}{l}\text { Develop ability to think holistically: to see both parties } \\
\text { as a whole. }\end{array}$ & & & & \\
\hline 5 & Develop skills to think creatively. & & & \\
\hline 6 & $\begin{array}{l}\text { Develop skills to distinguish between facts and } \\
\text { opinions. }\end{array}$ & & & & \\
\hline 7 & Improve the ability to listen. & & & & \\
\hline 8 & Improving the ability to communicate. & & & \\
\hline 9 & $\begin{array}{l}\text { Learn the concepts and theories related to } \\
\text { entrepreneurship. }\end{array}$ & & & & \\
\hline 10 & $\begin{array}{l}\text { Learn techniques and methods used to create } \\
\text { business. }\end{array}$ & & & & \\
\hline 11 & Develop new ideas. & & & & \\
\hline 12 & Develop a love for learning. & & & \\
\hline 13 & $\begin{array}{l}\text { Develop an understanding of the role of science and } \\
\text { technology. }\end{array}$ & & & & \\
\hline 14 & Develop the ability to work productively with others. & & & & \\
\hline 15 & Develop management skills. & & & & \\
\hline 16 & Develop leadership skills. & & & & \\
\hline 17 & Develop a commitment to a job well done. & & & & \\
\hline 18 & Improve the ability to follow instructions and plans. & & & & \\
\hline 19 & Improve ability to organize and use time effectively. & & & & \\
\hline 20 & Develop interest in obtaining personal achievements. & & & & \\
\hline 21 & Developing the ability to perform the skills. & & & & \\
\hline 22 & $\begin{array}{l}\text { Cultivate a sense of responsibility for their own } \\
\text { behavior. }\end{array}$ & & & & \\
\hline 23 & Improving self-esteem and self-confidence & & & & \\
\hline 24 & Develop a commitment to personal values . & & & & \\
\hline 25 & Develop respect for the values themselves. & & & & \\
\hline 26 & Cultivate emotional health and wellbeing. & & & & \\
\hline 27 & Develop the ability to think for oneself. & & & & \\
\hline 28 & Develop the ability to make good decisions & & & & \\
\hline & & & & & \\
\hline
\end{tabular}

\section{SOCIODEMOGRAPHIC DATA}

27. Please indicate the name of the university for which you work (please specify region).

28. Indicate Gender

Female Male

29. Please indicate your year of birth

30. Which is your full name?

31. What is your e-mail? 


\section{APPENDIX E}

\section{SURVEY FACULTY (SPANISH)}

\section{CONSENTIMIENTO INFORMADO}

Usted ha sido invitado a participar en el estudio "Efectos de un curso obligatorio de emprendimiento en la intención de emprender". El objetivo de este estudio es conocer el efecto que un curso obligatorio de emprendimiento tiene en la intención a emprender en sus estudiantes. Al contestar, por favor piense en el curso de emprendimiento que está actualmente enseñando o que enseñará en un futuro inmediato. La información que provea es confidencial y sólo será usada en esta investigación, sin identificar a los participantes. El tiempo promedio que demorará en responder es de 20 minutos. Tu participación consistirá en responder preguntas de una encuesta al comienzo y al final de su curso de emprendimiento. La encuesta tomará aproximadamente 20 minutos responder. Toda información que se recoja será confidencial, por lo que no se usará para ningún otro propósito fuera de esta investigación. Las respuestas al cuestionario serán codificadas usando un número de identificación y se manejarán de forma anónima. Dicha información no será conocida por otras personas que no sean el investigador titular o la persona a cargo de los estudios. Usted puede negarse a contestar algunas preguntas y puede retirar su participación en el estudio en cualquier momento que desee. Si tiene alguna duda sobre este proyecto, puede hacer preguntas en cualquier momento durante su participación en él. Este proyecto cuenta con el apoyo de FONDECYT. El Nº de proyecto es 11121458 y está a cargo del Dr. Carlos Albornoz (calbornoz@udd.cl), profesor de la Facultad de Economía y Negocios de la Universidad del Desarrollo.

ACEPTO PARTICIPAR

NO ACEPTO

\section{AUTOEFICACIA EMPRENDEDORA}

1. De 0 a 100, ¿Qué tan bueno te consideras para hacer las siguientes tareas? (evalúate de 0 a 100)

\begin{tabular}{|l|l|l|}
\hline$\#$ & Preguntas & De 0 A 100 \\
\hline 1 & Encontrar una idea nueva de producto o servicio & \\
\hline 2 & $\begin{array}{l}\text { Juntarme con otros a hacer lluvia de ideas para encontrar } \\
\text { nuevos productos o servicios }\end{array}$ & \\
\hline 3 & Identificar la necesidad de un nuevo producto o servicio \\
\hline 4 & $\begin{array}{l}\text { Diseñar un producto o servicio que satisface las necesidades } \\
\text { o deseos de potenciales clientes }\end{array}$ & \\
\hline 5 & Estimar la demanda que tendría un producto & \\
\hline 6 & $\begin{array}{l}\text { Determinar el precio óptimo al cual debiera venderse el } \\
\text { producto }\end{array}$ & \\
\hline 7 & Saber cuánto dinero se necesita para comenzar un negocio & \\
\hline 8 & $\begin{array}{l}\text { Diseñar una campaña efectiva para vender un producto o } \\
\text { servicio }\end{array}$ & \\
\hline 9 & $\begin{array}{l}\text { Hacer que otros crean en mi idea y se inspiren en mi visión } \\
\text { del futuro }\end{array}$ & \\
\hline 10 & $\begin{array}{l}\text { Desarrollar y utilizar redes de contactos en beneficio de un } \\
\text { negocio }\end{array}$ & \\
\hline 11 & Explicar, de manera clara y concisa, una idea de negocio & \\
\hline 12 & Supervisar empleados & \\
\hline 13 & Reclutar y contratar personas & \\
\hline 14 & Delegar tareas y responsabilidades en los empleados & \\
\hline 15 & $\begin{array}{l}\text { Lidiar efectivamente con los problemas del día a día de un } \\
\text { negocio }\end{array}$ & \\
\hline 16 & Inspirar, animar, y motivar empleados & \\
\hline 17 & Entrenar empleados & \\
\hline
\end{tabular}




\begin{tabular}{|l|l|l|}
\hline 18 & Mantener las cuentas del negocio ordenadas & \\
\hline 19 & $\begin{array}{l}\text { Manejar adecuadamente activos financieros de un negocio } \\
\text { (dinero, maquinarias, y cosas de valor) }\end{array}$ & \\
\hline 20 & Leer e interpretar balances financieros & \\
\hline
\end{tabular}

IX. PERSPECTIVAS DE Enseñanza (3 preguntas)

2. ¿Qué es lo que usted cree acerca de la enseñanza o la instrucción? (Creencias)

Para cada enunciado seleccione la respuesta que mejor representa su acuerdo o desacuerdo.

\begin{tabular}{|c|c|c|c|c|c|c|}
\hline$\#$ & PREGUNTAS & $\begin{array}{l}\text { Muy en } \\
\text { desacuer } \\
\text { do }\end{array}$ & $\begin{array}{l}\text { En } \\
\text { desacuer } \\
\text { do }\end{array}$ & Neutral & $\begin{array}{l}\text { De } \\
\text { acuerdo }\end{array}$ & $\begin{array}{l}\text { Muy de } \\
\text { acuerdo }\end{array}$ \\
\hline 1 & $\begin{array}{l}\text { El aprendizaje se beneficia cuando } \\
\text { hay objetivos predeterminados. }\end{array}$ & & & & & \\
\hline 2 & $\begin{array}{l}\text { Para ser un profesor efectivo uno } \\
\text { debe poner en práctica lo que predica }\end{array}$ & & & & & \\
\hline 3 & $\begin{array}{l}\text { Por encima de todo, el aprendizaje } \\
\text { depende de lo que uno ya sabe }\end{array}$ & & & & & \\
\hline 4 & $\begin{array}{l}\text { Es importante reconocer las } \\
\text { reacciones emocionales de los } \\
\text { alumnos }\end{array}$ & & & & & \\
\hline 5 & $\begin{array}{l}\text { Mi enseñanza se centra en el cambio } \\
\text { social, no el alumno individual }\end{array}$ & & & & & \\
\hline 6 & $\begin{array}{l}\text { Los profesores deben tener un } \\
\text { completo dominio de su tema }\end{array}$ & & & & & \\
\hline 7 & $\begin{array}{l}\text { El mejor aprendizaje viene de trabajar } \\
\text { junto a los buenos profesionales }\end{array}$ & & & & & \\
\hline 8 & $\begin{array}{l}\text { La enseñanza debe centrarse en el } \\
\text { desarrollo de los cambios cualitativos } \\
\text { en el pensamiento }\end{array}$ & & & & & \\
\hline 9 & $\begin{array}{l}\text { En mi enseñanza, la construcción de } \\
\text { confianza en sí mismo en los } \\
\text { estudiantes es una prioridad }\end{array}$ & & & & & \\
\hline 10 & $\begin{array}{l}\text { El aprendizaje individual sin cambio } \\
\text { social no es suficiente }\end{array}$ & & & & & \\
\hline 11 & $\begin{array}{l}\text { Los maestros efectivos deben } \\
\text { primero ser expertos en sus propias } \\
\text { áreas temáticas }\end{array}$ & & & & & \\
\hline 12 & $\begin{array}{l}\text { El conocimiento y su aplicación no se } \\
\text { pueden separar }\end{array}$ & & & & & \\
\hline 13 & $\begin{array}{l}\text { La enseñanza debe basarse en lo } \\
\text { que la gente ya sabe }\end{array}$ & & & & & \\
\hline 14 & $\begin{array}{l}\text { En el aprendizaje, el esfuerzo de la } \\
\text { gente debe ser recompensado tanto } \\
\text { como logro }\end{array}$ & & & & & \\
\hline 15 & $\begin{array}{l}\text { Para mí, la enseñanza es un acto } \\
\text { moral tanto como una actividad } \\
\text { intelectual }\end{array}$ & & & & & \\
\hline
\end{tabular}


3. ¿Qué busca alcanzar cuando enseña o instruye? (Intenciones)

Para cada enunciado seleccione la repuesta que mejor indique la frecuencia con que usted logra cumplir sus propósitos cuando enseña.

\begin{tabular}{|c|c|c|c|c|c|c|}
\hline$\#$ & PREGUNTAS & $\begin{array}{l}\mathrm{N}= \\
\text { Nunca }\end{array}$ & $\begin{array}{l}\mathrm{R}=\text { Rara } \\
\text { vez }\end{array}$ & $\begin{array}{l}A= \\
\text { Algunas } \\
\text { veces }\end{array}$ & $\begin{array}{l}U= \\
\text { Usualme } \\
\text { nte }\end{array}$ & $\begin{array}{l}\text { S }= \\
\text { Siempre }\end{array}$ \\
\hline 1 & $\begin{array}{l}\text { Mi intención es preparar a las } \\
\text { personas para los exámenes }\end{array}$ & & & & & \\
\hline 2 & $\begin{array}{l}\text { Mi propósito es demostrar cómo } \\
\text { desempeñarse o trabajar en } \\
\text { condiciones reales }\end{array}$ & & & & & \\
\hline 3 & $\begin{array}{l}\text { Mi propósito es ayudar a la gente a } \\
\text { desarrollar métodos más complejos } \\
\text { de razonamiento }\end{array}$ & & & & & \\
\hline 4 & $\begin{array}{l}\text { Mi propósito es el de fomentar en mis } \\
\text { alumnos el desarrollo de la } \\
\text { autoestima y confianza en su calidad } \\
\text { de alumnos }\end{array}$ & & & & & \\
\hline 5 & $\begin{array}{l}\text { Mi propósito es hacer que las } \\
\text { personas reconsideren sus valores } \\
\text { seriamente }\end{array}$ & & & & & \\
\hline 6 & $\begin{array}{l}\text { Espero que las personas sean } \\
\text { capaces de manejar una gran } \\
\text { cantidad de información relacionada } \\
\text { con la materia }\end{array}$ & & & & & \\
\hline 7 & $\begin{array}{l}\text { Espero que las personas apliquen el } \\
\text { contenido de la materia en la vida real }\end{array}$ & & & & & \\
\hline 8 & $\begin{array}{l}\text { Espero que las personas desarrollen } \\
\text { nuevas maneras de pensar el } \\
\text { contenido de la materia }\end{array}$ & & & & & \\
\hline 9 & $\begin{array}{l}\text { Espero que las personas aumenten } \\
\text { su autoestima a través de mi } \\
\text { metodología enseñanza }\end{array}$ & & & & & \\
\hline 10 & $\begin{array}{l}\text { Espero que las personas estén } \\
\text { comprometidas para cambiar nuestra } \\
\text { sociedad }\end{array}$ & & & & & \\
\hline 11 & $\begin{array}{l}\text { Quiero que las personas saquen } \\
\text { buenas notas en los exámenes } \\
\text { gracias a mis métodos de enseñanza }\end{array}$ & & & & & \\
\hline 12 & $\begin{array}{l}\text { Quiero que las personas comprendan } \\
\text { la realidad del mundo laboral }\end{array}$ & & & & & \\
\hline 13 & $\begin{array}{l}\text { Quiero que las personas se den } \\
\text { cuenta de lo complejas e } \\
\text { interrelacionadas que son las cosas }\end{array}$ & & & & & \\
\hline 14 & $\begin{array}{l}\text { Quiero mantener un balance entre mi } \\
\text { preocupación y por los estudiantes el } \\
\text { desafío cuando enseño }\end{array}$ & & & & & \\
\hline 15 & $\begin{array}{l}\text { Quiero hacer evidente lo que las } \\
\text { personas dan por hecho en una } \\
\text { sociedad }\end{array}$ & & & & & \\
\hline
\end{tabular}


4. ¿Qué hace usted cuando enseña o instruye? (Acciones)

Para cada enunciado seleccione la respuesta que mejor refleja su acción cuando enseña.

\begin{tabular}{|c|c|c|c|c|c|c|}
\hline$\#$ & PREGUNTAS & $\begin{array}{l}\mathrm{N}= \\
\text { Nunca }\end{array}$ & $\begin{array}{l}R=\text { Rara } \\
\text { vez }\end{array}$ & $\begin{array}{l}A= \\
\text { Algunas } \\
\text { veces }\end{array}$ & $\begin{array}{l}\mathrm{U}= \\
\text { Usualme } \\
\text { nte }\end{array}$ & $\begin{array}{l}\mathrm{S}= \\
\text { Siem } \\
\text { pre }\end{array}$ \\
\hline 1 & $\begin{array}{l}\text { Cubro todo el contenido de la } \\
\text { materia de manera precisa y en el } \\
\text { tiempo indicado }\end{array}$ & & & & & \\
\hline 2 & $\begin{array}{l}\text { Relaciono el contenido con } \\
\text { aplicaciones o escenarios de la vida } \\
\text { real }\end{array}$ & & & & & \\
\hline 3 & $\begin{array}{l}\text { Hago muchas preguntas mientras } \\
\text { que la enseño }\end{array}$ & & & & & \\
\hline 4 & $\begin{array}{l}\text { Siempre encuentro algo loable en el } \\
\text { trabajo o la contribución que hace } \\
\text { cada persona }\end{array}$ & & & & & \\
\hline 5 & $\begin{array}{l}\text { Utilizo el contenido de la materia } \\
\text { como una manera de enseñar } \\
\text { valores }\end{array}$ & & & & & \\
\hline 6 & $\begin{array}{l}\text { Mi metodología de enseñanza se } \\
\text { rige por los objetivos del curso }\end{array}$ & & & & & \\
\hline 7 & $\begin{array}{l}\text { Yo muestro las habilidades y } \\
\text { métodos involucrados en una buena } \\
\text { práctica docente }\end{array}$ & & & & & \\
\hline 8 & $\begin{array}{l}\text { Yo desafío maneras familiares de } \\
\text { entendimiento del contenido de la } \\
\text { materia }\end{array}$ & & & & & \\
\hline 9 & $\begin{array}{l}\text { Fomento la expresión de } \\
\text { sentimientos y emociones }\end{array}$ & & & & & \\
\hline 10 & $\begin{array}{l}\text { Enfatizo más los valores que el } \\
\text { contenido académico de la materia }\end{array}$ & & & & & \\
\hline 11 & Especifico lo que se ha de aprender & & & & & \\
\hline 12 & $\begin{array}{l}\text { Creo que los novatos aprenden de } \\
\text { las personas con mucha experiencia }\end{array}$ & & & & & \\
\hline 13 & $\begin{array}{l}\text { Fomento el cuestionamiento del } \\
\text { pensamiento de otros }\end{array}$ & & & & & \\
\hline 14 & $\begin{array}{l}\text { Comparto mis sentimientos y espero } \\
\text { lo mismo de mis alumnos }\end{array}$ & & & & & \\
\hline 15 & $\begin{array}{l}\text { Ayudo a que las personas vean la } \\
\text { necesidad de cambios en la } \\
\text { sociedad }\end{array}$ & & & & & \\
\hline
\end{tabular}




\section{METODOLOGIAS O TECNICAS DE ENSE;ANZA USADAS EN CLAS}

5. ¿Utiliza alguna(s) de la(s) siguiente(s) actividad(es) pedagógica(s) en su clase de emprendimiento?

\begin{tabular}{|l|l|l|l|}
\hline$\#$ & PREGUNTAS & SI & NO \\
\hline 1 & Analizo casos de estudio (tipo Harvard) & & \\
\hline 2 & $\begin{array}{l}\text { Asigno lecturas/temas a los alumnos para } \\
\text { posterior discusión grupal }\end{array}$ & & \\
\hline 3 & Consultoría hechas por alumnos & & \\
\hline 4 & $\begin{array}{l}\text { Desarrollo de planes de negocios por alumnos } \\
\text { en grupo }\end{array}$ & & \\
\hline 5 & $\begin{array}{l}\text { Ensayos, bitácoras, u otra forma de estimular } \\
\text { la reflexión individual }\end{array}$ & & \\
\hline 6 & $\begin{array}{l}\text { Entrego feedback para "remecer" la manera de } \\
\text { pensar }\end{array}$ & & \\
\hline 7 & Entrevistas a emprendedores & & \\
\hline 8 & $\begin{array}{l}\text { Implemento dinámicas de grupo dentro de la } \\
\text { sala de clases }\end{array}$ & & \\
\hline 9 & $\begin{array}{l}\text { Implemento Juegos o dinámicas grupales al } \\
\text { aire libre }\end{array}$ & & \\
\hline 10 & Invito charlistas que han sido emprendedores & & \\
\hline 11 & Muestro videos a los alumnos & & \\
\hline 12 & Presentación con power point y/o pizarra & & \\
\hline 13 & Uso simulaciones en computador & & \\
\hline 14 & Visitas a empresas (salidas a terreno) & & \\
\hline
\end{tabular}

6. ¿En cuál(es) de las metodologías o enfoques mencionados en la pregunta anterior usted ha recibido algún tipo de entrenamiento?

\begin{tabular}{|l|l|l|l|}
\hline$\#$ & PREGUNTAS & SI & NO \\
\hline 1 & Analizo casos de estudio (tipo Harvard) & & \\
\hline 2 & $\begin{array}{l}\text { Asigno lecturas/temas a los alumnos para } \\
\text { posterior discusión grupal }\end{array}$ & & \\
\hline 3 & Consultoría hechas por alumnos & & \\
\hline 4 & $\begin{array}{l}\text { Desarrollo de planes de negocios por alumnos } \\
\text { en grupo }\end{array}$ & & \\
\hline 5 & $\begin{array}{l}\text { Ensayos, bitácoras, u otra forma de estimular } \\
\text { la reflexión individual }\end{array}$ & & \\
\hline 6 & $\begin{array}{l}\text { Entrego feedback para "remecer" la manera de } \\
\text { pensar }\end{array}$ & & \\
\hline 7 & Entrevistas a emprendedores & & \\
\hline 8 & $\begin{array}{l}\text { Implemento dinámicas de grupo dentro de la } \\
\text { sala de clases }\end{array}$ & & \\
\hline 9 & $\begin{array}{l}\text { Implemento Juegos o dinámicas grupales al } \\
\text { aire libre }\end{array}$ & & \\
\hline 10 & Invito charlistas que han sido emprendedores & & \\
\hline 11 & Muestro videos a los alumnos & & \\
\hline 12 & Presentación con power point y/o pizarra & & \\
\hline 13 & Uso simulaciones en computador & & \\
\hline 14 & Visitas a empresas (salidas a terreno) & & \\
\hline
\end{tabular}




\section{DATOS DEL CURSO}

7. ¿Cuál es el nombre del curso que enseña?

8. ¿Cuál es el principal objetivo (resultado) de aprendizaje del curso de emprendimiento que enseña?

\section{EVALUACION DEL CURSO}

9. ¿Utiliza alguno(s) de lo(s) siguiente(s) métodos para verificar que los alumnos hayan alcanzado los objetivos de aprendizaje del curso?

\begin{tabular}{|l|l|l|l|l|}
\hline$\#$ & PREGUNTAS & SI & NO & NO SE \\
\hline 1 & Prueba o exámen escrito & & & \\
\hline 2 & Prueba o exámen oral & & & \\
\hline 3 & Plan de negocio escrito por alumnos en grupo & & & \\
\hline 4 & $\begin{array}{l}\text { Reporte de entrevista a emprendedores } \\
\text { realizadas por los alumnos }\end{array}$ & & & \\
\hline 5 & Exposiciones o presentaciones grupales & & & \\
\hline 6 & Videos realizados por los alumnos & & & \\
\hline 7 & $\begin{array}{l}\text { Puntaje en juegos o simulaciones de creación } \\
\text { de empresas }\end{array}$ & & & \\
\hline 8 & Ensayos/papers individuales & & & \\
\hline
\end{tabular}

\section{EXPERIENCIA DE EMPRENDIMIENTO}

10. ¿Has sido dueño de un negocio en el pasado?

$\mathrm{SI}$

11. ¿Cuántos empleados tenía el negocio que tuvo?

12. ¿Es usted actualmente dueño de un negocio?

SI NO

13. ¿Cuántos empleados tiene su negocio?

XIV. EXPERIENCIA PROFESIONAL Y ACADEMICA

14. ¿Cuál es su profesión u oficio?

15. ¿Actualmente a qué se dedica? (en qué trabaja)

16. ¿Cuál es el máximo nivel de estudios que alcanzó? 
17. ¿Qué tiempo dedica a la academia? (qué tipo de contrato tiene con la institución de educación superior)

18. ¿Qué tiempo dedica a la docencia en emprendimiento?

19. ¿Cuál es su principal motivación para hacer clases de emprendimiento?

\begin{tabular}{|l|l|l|l|}
\hline$\#$ & PREGUNTAS & De acuerdo & En desacuerdo \\
\hline 1 & Me lo asignan. & & \\
\hline 2 & $\begin{array}{l}\text { Considero que tengo las competencias para } \\
\text { ello. }\end{array}$ & & \\
\hline 3 & Tengo interés por el tema. & & \\
\hline 4 & Para generar un ingreso extra. & & \\
\hline
\end{tabular}

20. ¿Cuántos años lleva enseñando emprendimiento?

21. ¿Ha tenido usted entrenamiento sobre cómo hacer que sus alumnos aprendan más y mejor (cómo ser mejor pedagogo)?
SI
NO NO SE

22. ¿Cuándo ocurrió la capacitación o entrenamiento que usted recibió sobre cómo hacer que sus alumnos aprendan mejor?

23. Aproximadamente ¿Cuántas horas cronológicas de entrenamiento pedagógico estima usted que ha recibido a lo largo de toda su carrera?

\section{ENTRENAMIENTO PEDAGOGICO EN EMPRENDIMIENTO}

24. ¿Ha tenido usted entrenamiento específico sobre cómo enseñar emprendimiento?

$\mathrm{SI} \_$NO__ NO SE

25. Por favor describa qué tipo de entrenamiento ha recibido para enseñar emprendimiento. 
26. ¿Ha tenido usted entrenamiento específico sobre?

\begin{tabular}{|l|l|l|l|l|}
\hline$\#$ & TIPO DE ENTRENAMIENTO & SI & NO & NO SE \\
\hline 1 & Canvas de Osterwalder & & & \\
\hline 2 & Ontología del Lenguaje & & & \\
\hline 3 & Coaching Ontológico & & & \\
\hline 4 & PNL (Programación Neurolingüistica) & & & \\
\hline 5 & Lean StartUp & & & \\
\hline 6 & Eneagrama & & & \\
\hline 7 & Design Thinking & & & \\
\hline 8 & Modelo Timmons & & & \\
\hline 9 & Empretec & & & \\
\hline 10 & Sociotecnología & & & \\
\hline 11 & Biología del Conocimiento & & & \\
\hline 12 & El juego el Plan (Momento Cero) & & & \\
\hline 13 & CEFE & & & \\
\hline 14 & Babson College Model & & & \\
\hline 15 & Effectual Thinking & & & \\
\hline 16 & Desarrollo de Casos de estudio & & \\
\hline
\end{tabular}

27. Si desea, puede mencionar cuáles de los modelos de enseñanza antes mencionados usted actualmente usa en sus clases de emprendimiento.

\section{OBJETIVOS DE ENSENANZA-APRENDIZAJE DEL PROFESOR}

28. En relación con el curso de emprendimiento que usted realiza, en qué grado pretende alcanzar cada uno de los siguientes objetivos:

\begin{tabular}{|l|l|l|l|l|l|}
\hline$\#$ & PREGUNTAS & Nada & Algo & Poco & Mucho \\
\hline 1 & Desarrollar habilidades para resolver problemas. & & & & \\
\hline 2 & $\begin{array}{l}\text { Desarrollar habilidades para hacer inferencias } \\
\text { razonables a partir de observaciones. }\end{array}$ & & & & \\
\hline 3 & $\begin{array}{l}\text { Desarrollar habilidades de sintetizar e integrar } \\
\text { información e ideas. }\end{array}$ & & & & \\
\hline 4 & $\begin{array}{l}\text { Desarrollar habilidades para pensar de manera } \\
\text { holística: ver tanto las partes como el conjunto. }\end{array}$ & & & & \\
\hline 5 & Desarrollar habilidades de pensar de forma creativa. & & & & \\
\hline 6 & $\begin{array}{l}\text { Desarrollar habilidades para distinguir entre hechos y } \\
\text { opiniones. }\end{array}$ & & & & \\
\hline 7 & Mejorar la capacidad de escuchar. & & & \\
\hline 8 & Mejorar la capacidad de comunicar. & & & \\
\hline 9 & $\begin{array}{l}\text { Aprender los conceptos y las teorías relacionadas al } \\
\text { emprendimiento. }\end{array}$ & & & & \\
\hline 10 & $\begin{array}{l}\text { Aprender técnicas y métodos utilizados para crear } \\
\text { negocios. }\end{array}$ & & & & \\
\hline 11 & Desarrollar apertura a las nuevas ideas. & & & \\
\hline 12 & Desarrollar amor por el aprendizaje. & & & \\
\hline 13 & $\begin{array}{l}\text { Desarrollar una comprensión del rol de la ciencia y la } \\
\text { tecnología. }\end{array}$ & & & & \\
\hline 14 & $\begin{array}{l}\text { Desarrollar la capacidad para trabajar } \\
\text { productivamente con los demás. }\end{array}$ & & & & \\
\hline 15 & Desarrollar habilidades de gestión. & & & \\
\hline
\end{tabular}




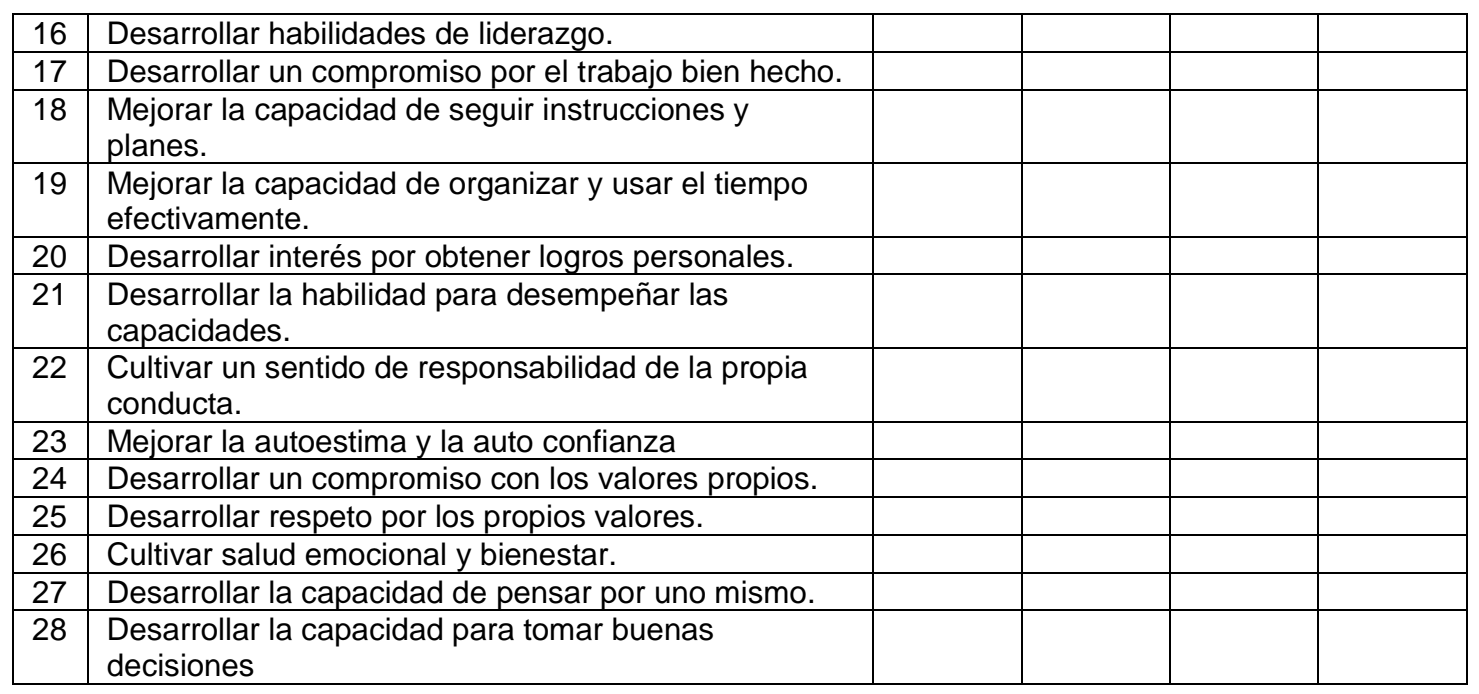

\section{DATOS SOCIODEMOGRAFICOS}

29. Por favor indique el nombre de la Institución para la cual usted trabaja (favor especificar región).

30. Indique Genero
Femenino
Masculino

31. Por favor indique su año de nacimiento

32. Cuál es tu nombre y apellido?

33. ¿Cuál es su correo electrónico? 


\section{APPENDIX F}

\section{INTERVIEW GUIDE FACULTY (ENGLISH)}

1. Tell me about your experience in teaching entrepreneurship

(10 minutes)

Probes What made you interested in teaching entrepreneurship, in general?

How did you start teaching in this area?

What you value most about teaching entrepreneurship?

2. How do you define entrepreneurship education?

(10 minutes)

Probes if not mentioned or very little discussion and time allows:

How do you describe educating students to act entrepreneurially?

Some people say that "entrepreneurship cannot be taught". What do you think?

How do you define entrepreneurship as a learning phenomenon?

3. What are the specific pedagogies that you are currently used in your classes?

Probes if not mentioned or very little discussion and time allows:

Tell me more about some good experiences and examples in teaching entrepreneurship

Tell me more about balancing workload outside classroom practice

Tell me more about dealing with time to use or not different pedagogies

4. What influenced you to select the pedagogies that you are using in your classes now? (10 minutes)

Probes What else? Who has something different?

Can you give me example of why you select those?

5. What do you like the most about the pedagogies from your current syllabus/current class: (10

minutes) Probes if not mentioned or very little discussion and time allows:

Are self-selected or are suggested by the university?

Why do you like those pedagogies?

What do you think about training on pedagogies and teaching methods in general?

6. Tell me more about the experience of implementation those pedagogies with students? (10 minutes)

Probes Students' reaction (positive/negatives/challenges)

What are pedagogies that you think do not work with university students, why?

What do you suggest to overcome difficulties?

What do you suggest to improve the current teaching practices?

7. What are the factors that prevent you from implementing new/different pedagogies? (10 minutes)

Probes if not mentioned or very little discussion and time allows

What do you think there are the main factors? (Personal u organizational)

8. Name and describe briefly $2-3$ pedagogical methods that you want to apply in the future: (10 minutes) Your Personal/professional interest

Probes if not mentioned or very little discussion and time allows:

Why or from whom you are inspired to implement those?

Wrap-up (10 minutes)

9. Imagine a positive future: What do you visualize will be a good class, given by you as entrepreneurship educator/faculty?

Ask them to name at least 2 characteristics of a good or effective entrepreneurship class

What do you need now to become that kind of teacher in entrepreneurship education in the future?

Anything else that you want to add to this interview? 


\title{
APPENDIX E
}

\section{INTERVIEW GUIDE FACULTY (SPANISH)}

\author{
1. Hábleme de su experiencia en la enseñanza del emprendimiento (espíritu empresarial) \\ (10 minutos) \\ ¿Qué te hizo interesarte en enseñanza del emprendimiento, en general? \\ ¿Cómo empezaste a enseñar en esta área? \\ ¿Lo que más valora de enseñanza del espíritu empresarial?
}

2. ¿Cómo define educación emprendedora? (10 minutos)

Si no se menciona o hay muy poca discusión y el tiempo lo permite:

¿Cómo describe la educación de los estudiantes a actuar con espíritu emprendedor?

Hay gente que dice que "el espíritu empresarial no se puede enseñar". ¿Qué piensa usted?

¿Cómo se define el espíritu empresarial como un fenómeno de aprendizaje?

3. ¿Cuáles son las pedagogías específicas que utilizas actualmente en tus clases? ( 10 Minutos )

Si no se mencionan o muy poca discusión y el tiempo lo permite:

Quisiera saber más sobre buenas experiencias y ejemplos en la enseñanza del espíritu empresarial

Quisiera saber más sobre el equilibrio de la carga de trabajo fuera de las horas de clases

Quisiera saber más sobre cómo utilizas o no las diferentes pedagogías en tu clase

4. ¿Qué te influyó para seleccionar las pedagogías que están utilizando en sus clases? ( 10 Minutos ) ¿Qué más? ¿Quién más tiene algo diferente?

¿Me puede dar ejemplo de por qué seleccionas estas pedagogías?

5. ¿Qué te gusta más acerca de las pedagogías de tu actual curso/ actual clase: ( 10 Minutos )

Si no se mencionan o muy poca discusión y el tiempo lo permite:

Las pedagogías son autoseleccionadas o son sugeridos por tu universidad?

¿Por qué te gustan esas pedagogías?

¿Qué piensa usted acerca de la formación en pedagogías y métodos de enseñanza en general?

6. Quiero saber más sobre la experiencia de la puesta en práctica esas pedagogías con los estudiantes? ( 10 Minutos):

¿Cuál es la reacción de los estudiantes (positiva/ negativa / algún reto)?

¿Cuáles son las pedagogías que usted piensa que no funcionan con los estudiantes universitarios, por qué? ¿Qué sugiere usted para superar las dificultades?

¿Qué sugiere para mejorar las prácticas de enseñanza actuales?

7. ¿Cuáles son los factores que impiden la implementación de nuevas y diferentes pedagogías? (10 Minutos): Si no se mencionan o muy poca discusión y el tiempo lo permite

¿Cuáles son los principales factores? (factores personales y/o de la organización)

8. Menciona y describe brevemente 2-3 métodos pedagógicos que desea aplicar en el futuro: (10 min): Si no se mencionan o muy poca discusión y el tiempo lo permite: Menciona tu interés profesional y personal. ¿Por qué o de quién estás inspirado para poner en práctica esos?

\section{Finalizar (10 minutos)}

9. Imagine un futuro positivo: ¿Qué quieres visualizar será una buena clase, dada por usted como educador? Pedir que nombren al menos 2 características de una buena o eficaz clase de emprendimiento. ¿Qué necesitas ahora para convertirte en ese tipo de profesor en la educación del emprendimiento en el futuro? ¿Algo más que desees agregar en esta entrevista? 